Historic, archived document

Do not assume content reflects current scientific knowledge, policies, or practices. 



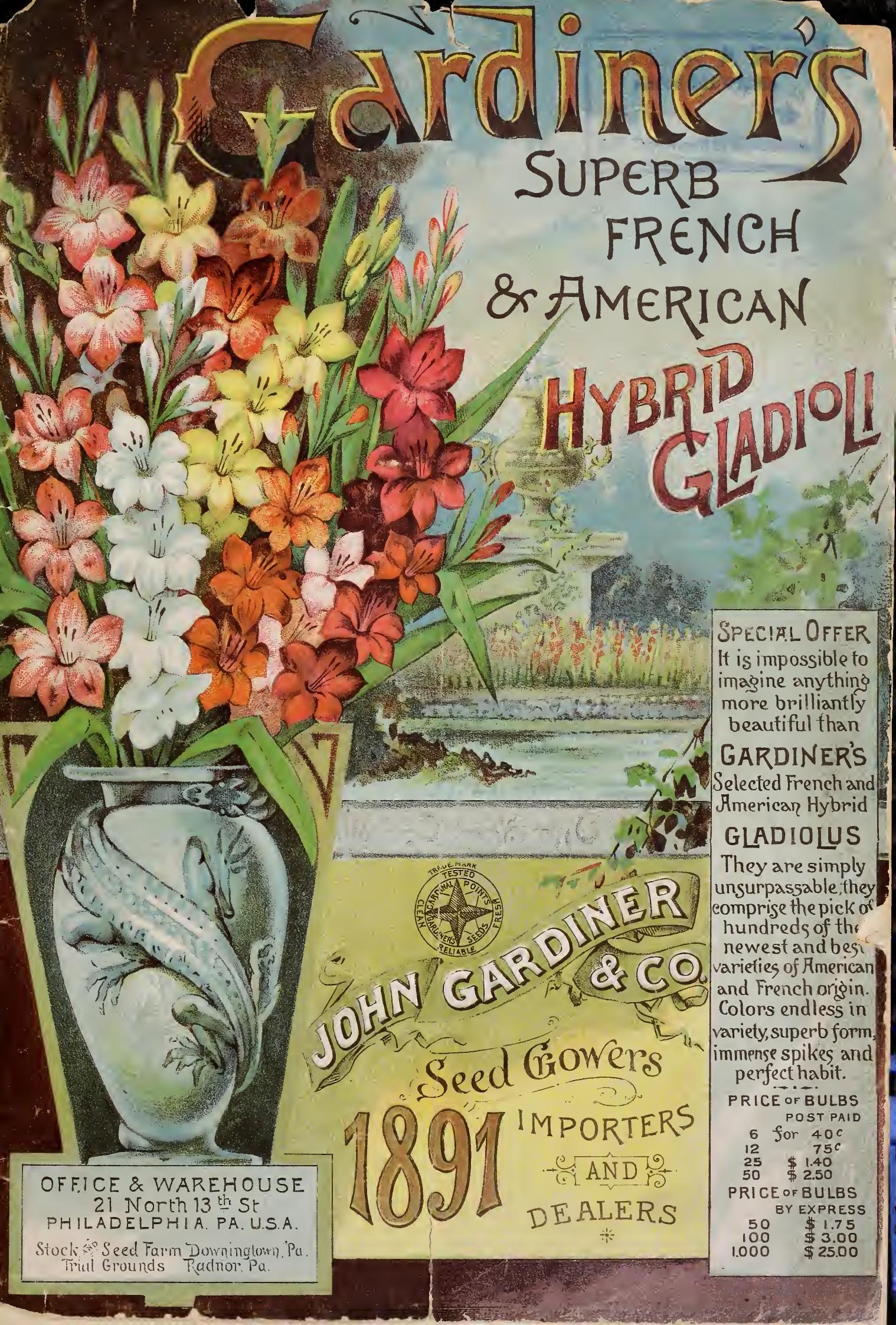




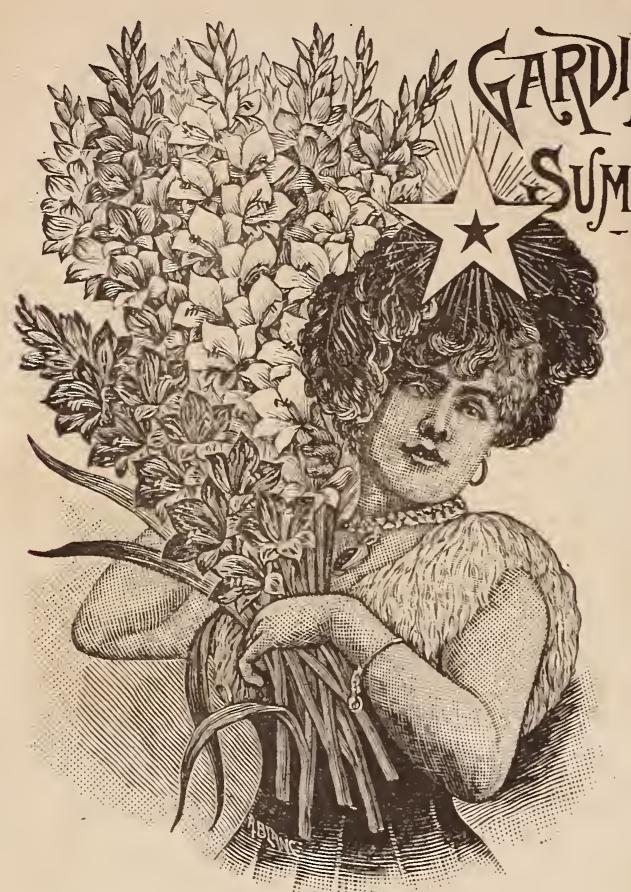

The following choice assortments of named Gladioli are put up in boxes, each bulb being carefully labelled, and each variety distinct and different. To get the greatest contrast and variety of color possible in a limited number of sorts, has been our aim in selecting the varieties. Mailed free at prices quoted. Single bulbs of any variety, Ioc.

\section{OUR $\pitchfork$ STAR COLLECTION NO. 1.} 10 FINE NAMED VARIETIES FOR 50 CTS.

I. CERES. Pure white, spotted with purpiish rose.

2. EUGENE SCRIBE. Tender rose, blazed with carmine.

3. GENERAL SHERMAN. Fine scarlet, large.

4. ISAAC BUCHANAN, Yellow, very fine.

5. JOHN BULL. White, lightly tinged with sulphur.

6. LAMARCK. Cherry, blazed with red, large, pure white stain, long spike.

7. LE POUSSIN. Light red, white blotch

8. MARIA DUMORTIER: White, slightly streaked with rose, MAlet purple

Io. NAPOLEON III. Scarlet striped white.

\section{OUR $\pitchfork$ STAR COLLECTION NO. 2.} IO FINE NAMED VARIETIES FOR 75 CTS.

I. AMBROSE VERSCHAFFELT. Rosy carmine, flamed with garnet: large rose blotch.

2. ANTONIUS. Scarlet, flamed carmine; pure white blotch. 3. COURANTI FULGENS. Dark crimson.

4. FELICIEN DAVID. Cherry, feathered light carmine; large white blotch.

5. JAMES VEITCH. Bright crimson; violet blotch.

6. MARGARITA. White ground, slightly suffused with light carmine.

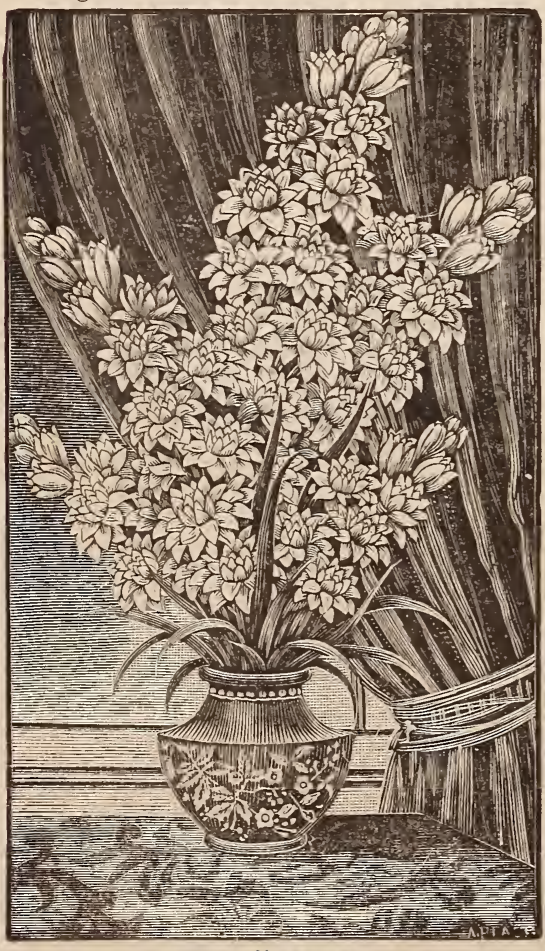

PEARL TUBEROSE.
7. MEYERBEER. Brilliant scarlet, flamed with vermilion; amaranth blotch.

8. NESTOR. Light yellow, lower petals darker, striped red. 9. OVIDE. Splendid spike of carmine red flowers, with a lilac sheen, flamed towards the edges with garnet red; pure white blotch.

Io. PRINCESS OF WALES. White, flamed with carmine rose; deep carmine blotch.

\section{$\star \star$ OUR DOUBLE STAR PACKAGE.}

\section{VARIETIES FOR \$1.00.}

To those wishing the complete list of 20 named varieties, as above, we will supply the same to one address. One bulb of each, all correctly labelled, free by mall for one dollar. $R$ ? We anticipate a run on this * * double star package (the most remarkable offer ever made in Gladioli), and would therefore advise early orders as we do not expect our stock, large though it is, to hold out to the end of the season.

GARDINER'S SELECTED GLADILI. In Separate Colors for Bedding or Forcing. White and light grounds (no dark colors), EACH. DOZ. 100.

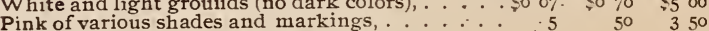

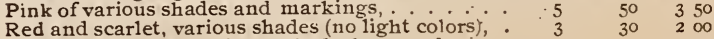
Striped and variegated, mostly dark grounds, : . $\begin{array}{lll}3 & 30 & 2 \\ 3 & 30 & 30\end{array}$ Yel!ow and yellow grounds, various markings, . . . $\quad 5 \quad 50 \quad 350$ Mailing, 5c. doz. on the abovie.

\section{GARDINER'S SUPERFINE MIXTURE OF ALL COLORS.}

We call your attention on cover of this catalogue to this mixture. No picture can do these superb flowers full justice. They are simply grand. picture can do these cover. We have also a cheaper mixture, which, in and surpasses the "best" of many dealers. We sell it as

\section{GARDINER'S FINE MIXED.}

We guarantee this mixture to contain not more than 10 per cent. of We guaranteysis. Where a large showy bed is wanted at a low cost, this mixture will prove very satisfactory. 25c. doz., \$1.50 per 100, $\$ 12.00$ per I,000. Mailing, $5 \mathrm{c}$. doz.

EXCELSIOR PEARL TUBEROSES.

Dwarf-growing, with long spikes, very double. Fine large bulbs, $35 \mathrm{C}$. doz., \$2.50 per 100. Mailing, Ioc. doz. 


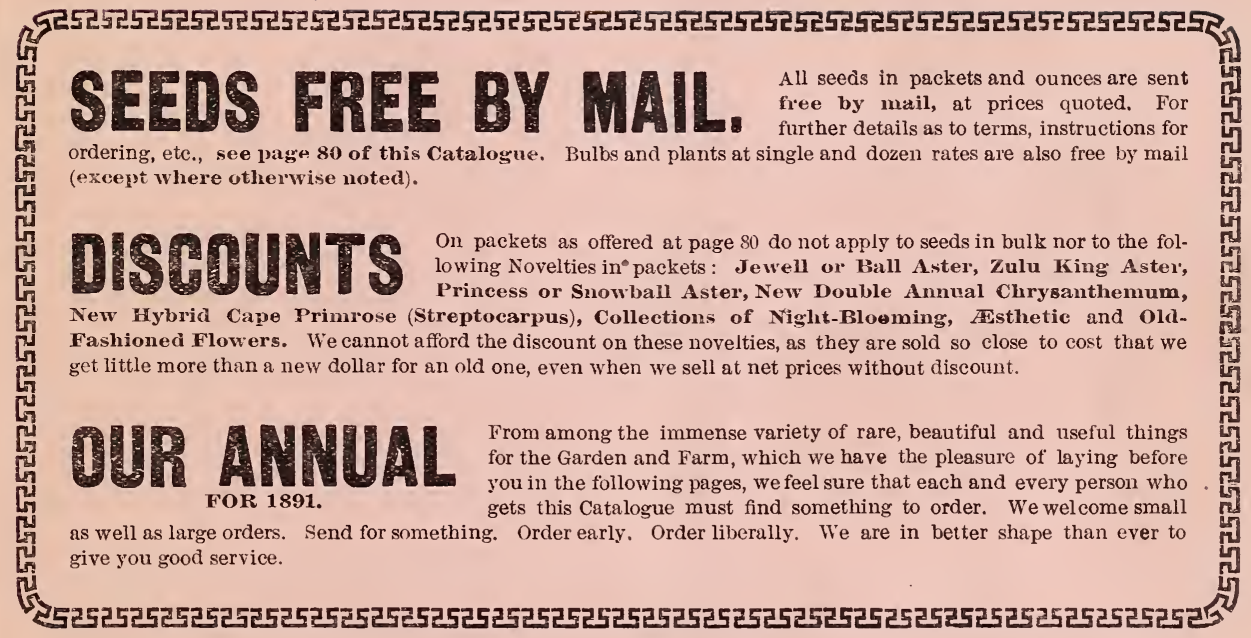




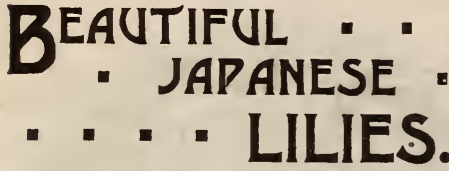

Imported direct from the Japanese Bulb Farms by JOHN GARDINER \& Co. Seed Growers, Importers and Dealers, Philadel phia, Pa., U. S. A.

"QUEEN \& OF \& LILIES."

THE GOLDEN-RAYED LILY OF JAPAN (Lilium auratum), - Ivcry-white, thickly strewn with purple studs, with a broad band of light golden-yellow extending from tip to base of each petal. Very large and fragrant. We offer again this season a splendid stock of sound, well-ripened bulbs, our own direct importation from Jatiful Lily within reach of all Each $20 c$., doz. $\$ 2.00$; mailing,

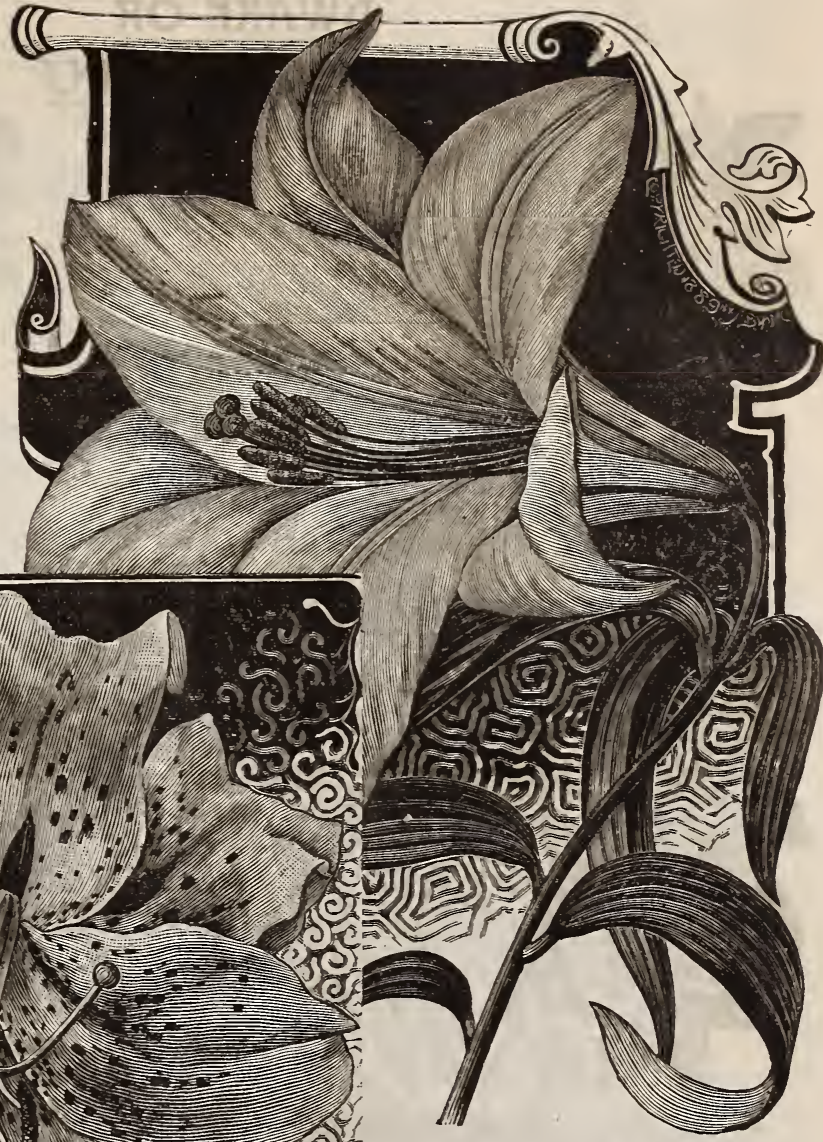

ROSE-CoLORED JAPANESE IILY.

\section{(Lilium Krameri.)}

\section{ROSE-COLORED JAPANESE}

\section{LILY (Lilium Krameri)}

One of the rarest and most delicately beau tiful of the Japanese Lilies. It is indigenous to the mountains of Senano, in the island of Nipon, and also to the hills near Kioto, at an elevation of three to four thousand feet above sea level. Ouite distinct in characte from any other lily in cuItivation, the foliage and stem resemble a slender growing auretum, the flowers are of a lovely rose color and of the form shown in the engraving; sweetscented, chaste and refined in form. The bulbs of Krameriare about the size of a walnut-bulbs even smaller than this will produce nut-bulbs even smaller than this will produce a flower-and require the same treatment as auratum. Customers who were disappointed on account of the scarcity of the bulbs last season will please send in their orders early. (9) Standing orders will receive first attention as soon as the bulbs arrive (about January 1st). Each 30c., doz. $\$ 3.00$; mailing, $10 \mathrm{c}$, doz SPECIOSUM PUNCTATUM-Blush gronnd spotted with crim and charming : a dist nct anished for its delic, distinguished for its delicacy and well as for its grace of form well as for its grace of form $\$ 5.00$ doz.; mailing, $2 c$. each.

\section{SPECIOSUM GROUP}

OF JAPANESE LILIES.

SPECIOSUM RUBRUM (Syn. Lancifolizm

\section{SPECIOSUM}

SPECIOSUM RUBRUM Syn. Lancifolium rubrum). -White, heavily spotted with rich crimson. The Speciosum and its varieties are magnificent border plants, and are also excellent

SPECIOSUM ALBUM.-Large white flowers, with a greenish band per doz; mailing, 3c. each. Extra selected, 400 . each, $\$ 4.00$ per doz.; mailing, 4c, each.

Speciosum roseum. - White, stained and spotted rose. 15c. each, $\$ 1.50$ doz, mailing, 2 , each. pot culture, Each 15c., doz. \$1.50; main running through the centre of each petal: very fine. 25c. each, \$2.50 


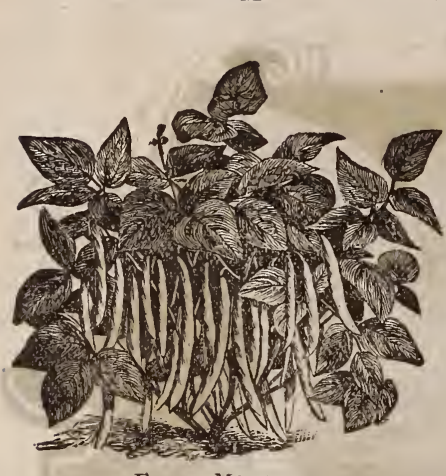

DWARF OR

\section{BUSH BEANS}

Green Pod Varieties.

IMPROVED EXTRA EARLY RED SPECKLED VALEN-

TINE.-At least ro day's earlier

in 35 days; unexcelled for market purposes, on account of its extreme ing. I5c. Pt. 1oc., qt. 3oc. Mailing. I5c. qt. Speckled Valentine. -Round, green pods; early' and tender; good for string or pickling. Pkt roc., qt. 25c. Mrailing, Early Mohawk.-Long, straight. flat pods; early, hardy and productive Pkt. Ioc., qt. 25c. MlailExtra FarLY REFtgee.

Early Yellow Six Weeks.-Full, flat pods: early: productive: BEST OF ALL.-Long, fleshy; succulent pods; stringless and excellent. Pkt. Isc., qt. $25 \mathrm{c}$. Nrailing, ${ }_{5} \mathrm{c}$. qt.

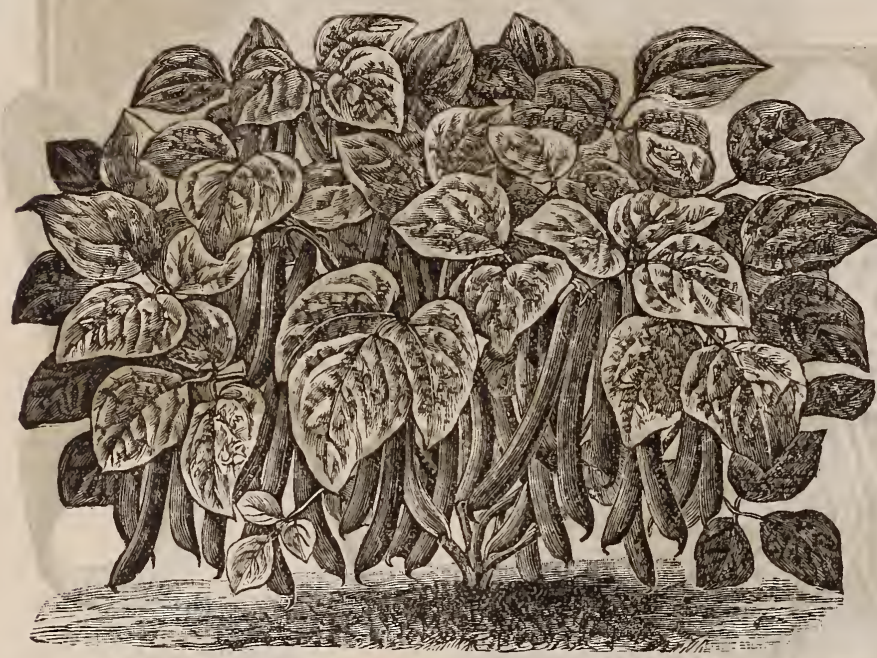

BEST OF ALL.

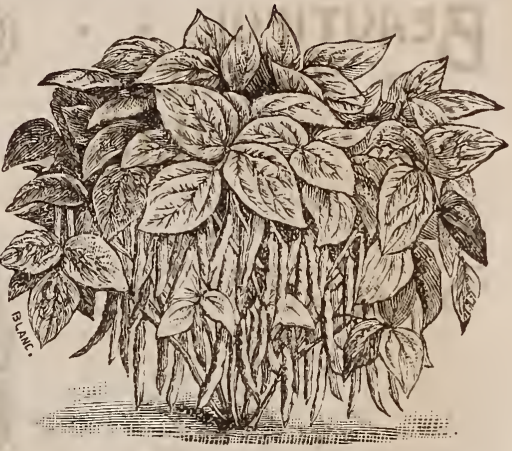
market. Pkt roc., qt. 25 c. Mailing, I5c. qt. Extra Early Refugee.-Large; productive; hardy ; tender, fleshy pods ; a great improvenent on the old Refugee. Pkt. roc., qt. 25c. Mailing. I5c. qt.

Early China.-Early ; prolific : good for string or shell. Pkt. roc., qt. $25 \mathrm{c}$. Mailing, I5c. qt.

LOW'S CHAMPION.-Long, handsome pods: superb quality, either gree: or ripe; productive ; vigorous; free from string or shell. Pkt. Ioc., qt. 30c. Mailing, ${ }_{5}$ c. qt.

Improved Dwarf Horticultural (syn. Goddard, Boston Favorite)-Large ; early; excellent for market; splendid shell beau. Pkt. roc., qt. 25c. Mailing, I5 $_{5}$ c. qt.

Wonder of France.-Iong, straight bright green pods; retains its beautiful green color even when cooked; early; productive; one of the finest shell beans. Pkt. roc., qt. 30c. Mailing, ${ }_{5} \mathrm{c}$. qt.

EMPEROR WILLIAM OR BROAD SWORD. - The largest podded bush bean early: prolific; good quality; enormously large, flat, green pods. Pkt. Ioc. qt., 3oc. Mailing, $\mathrm{i}_{5} \mathrm{c}$. qt.

White Marrowfat.-One of the best for use in a dry state in winter; fine bearer excellent quality. Pkt. Ioc., qt 20c. Mailing, I5c. qt.

White Kidney.-Excellent shell bean, green or ripe. Pkt. roc., qt. 20c. Mailing,

Burlingame's Medium Field.-A favorite sort in the great Navy Field.-Well-known standard sort for field culture. Pkt. bean-growing districts of New York; early; productive; fine Ioc., qt. 20c. Mailing, I5c. qt. quality. Pkt. Ioc, qt. $20 c^{2}$ Mailing, $5 c$,

Prolific Tree Field.-One of the most prolific varieties in cultivation; of very erect habit; good quality. Pkt. Ioc., qt. 2oc. Mailing, i5c. qt.

HENDERSON'S BUSH IIMA.-A dwarf variety of the Sieva or Southern Lima. The bushes are about $I_{5}$ or 18 inches in height. and require no stakes. It is remarkably early ; very productive and undoubtedly one of the most valuable vegetable novelties recently introduced. The beans shown in the detached pod in the engraving are natural size. Pkt. Ioc., qt. 75c. Mailing, I5c. qt.

Special Prices on large quantities to Market on application.

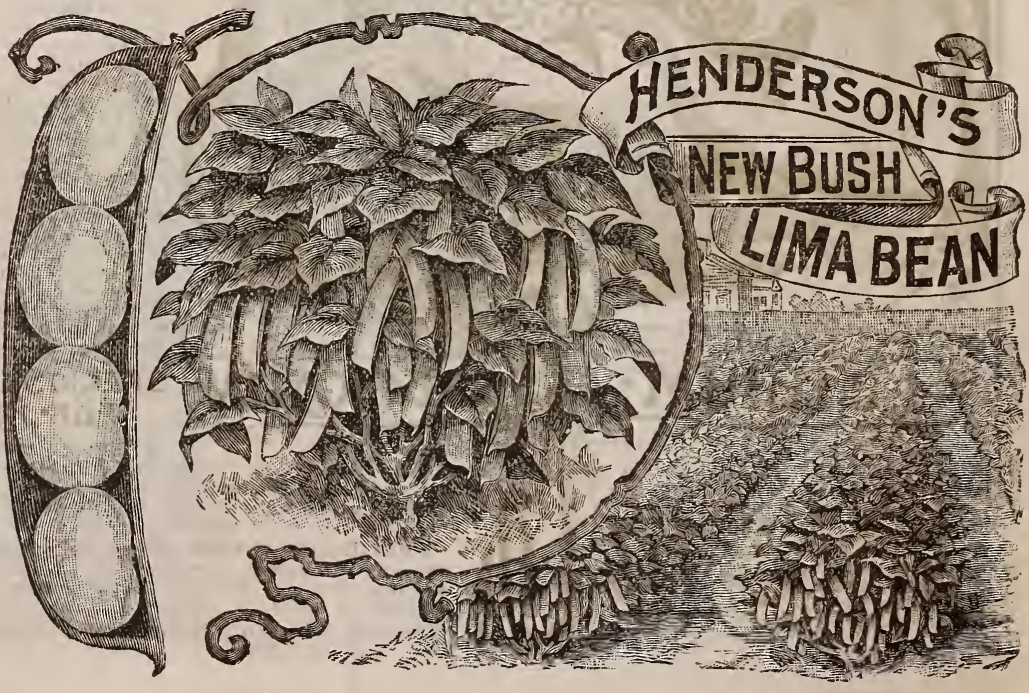




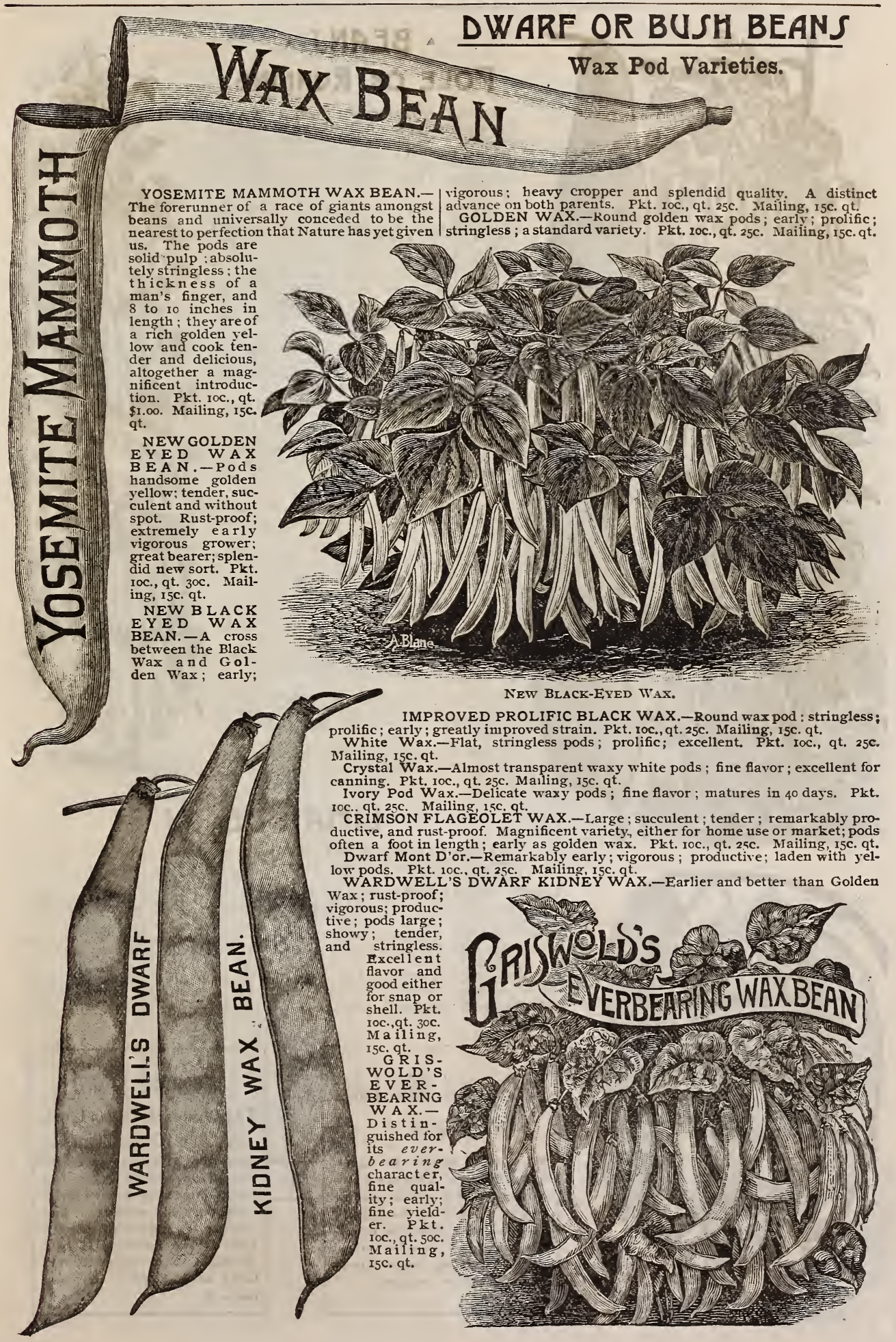




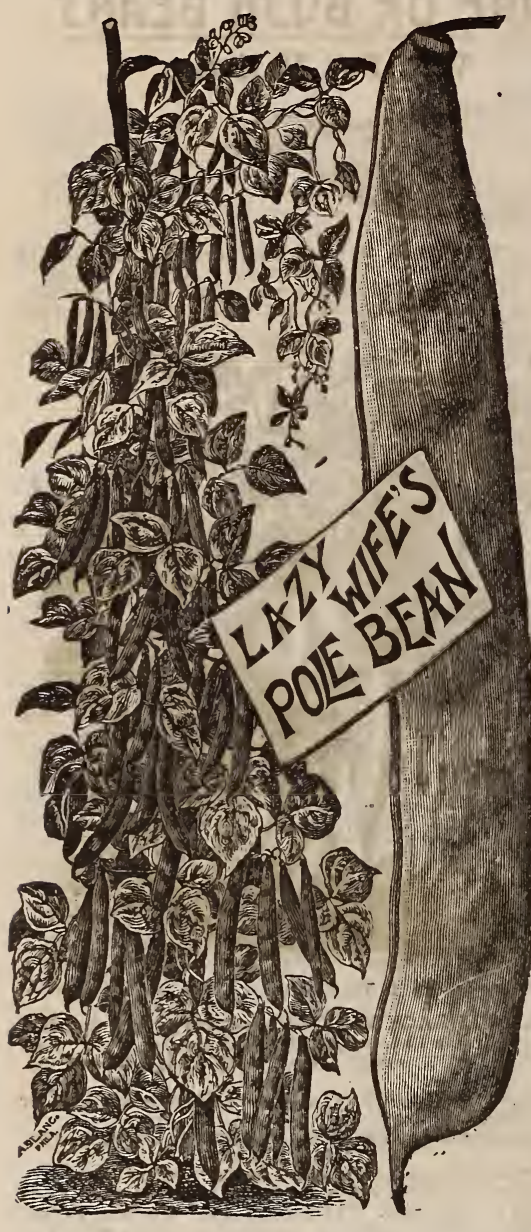

\section{$\triangle$ BEANS - POLE OR RUNAING.}

EARLY GOLDEN CLUSTER WAX.Long golden yellow pods, borne in clusters; extra early ; stringless, snaps easily ; vigorous, prolific, popular; quality tender, delicious; continues till frost. P1t. Ioc., qt. 5oc. Mailing, I5c. qt.

BEST OF ALL.-One of the finest pole beans of recent introduction; pods medium length, round, beautiful light green-almost crystal-entirely stringless; remarkably rich, tender and buttery when cooked; fit for use when only 2 or 3 inches long; tender and rich flavored even when fully ripe; extremely productive and good for a string bean even in winter; very scarce. Pkt. Ioc. qt. 5oc. Mailing, 15 c. qt.

Golden Andalusia.-Pods broad, flat, entirely stringless, 5 or 6 inches long ; rich, buttery, fine flavor; enormously productive. Pkt. IOc., 6 pkts. 50c., 12 pkts. $\$ 1.00$.

LAZY WIFE.-Large pale green pods: very thick meated; stringless; rich, tender and buttery; ripens early; clings well to the pole; enormously productive; splendid either as a snap or shell bean; retains its exquisite flavor until nearly ripe. pkt. roc., qt. 5oc. Mailing, I5c. qt.

Dutch Caseknife-Long green, fiat pods: rood for either string or shell : early, excellent. Pkt. roc., qt. $25 \mathrm{c}$. Mailing, 15c. qt.

Horticultural or Speckled Cranberry.Popular, profitable, excellent for string or shell. Pkt. Ioc., qt. 25c. Mrailing, 15c. qt.

Southern Prolific (syn. Kentucky Wonder).Long round pods, produced in clusters: splendid string bean; earlv, prolific profitable. Pkt. roc., qt. 3oc. Mailing, I5c. qt.

Black Wax.-Pods yellow, thick, tender, excellent; good snap bean. Pkt. Ioc., qt. $35 \mathrm{c}$.

Scarlet Runner--Very ornamental on account of its bright scarlet flowers; also a good string bean. Pkt. 10c., qt. 25c. Mailing, 15c. qt.

White Runner.-Similar to the preceding flowers white. Pkt. Ioc., qt. 25c. Mailing, r5c. qt.

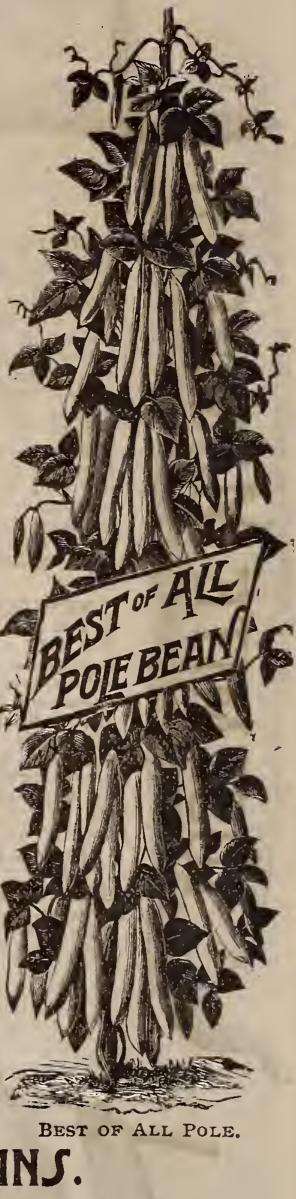

\section{LIMA \& BEANS.}

EXTRA EARLY JERSEY LIMA.-In size and appearance about the same as Large White Lima, but Io to I4 days earlier. Pkt. Ioc., qt. 6oc. Mailing, 15c. qt.

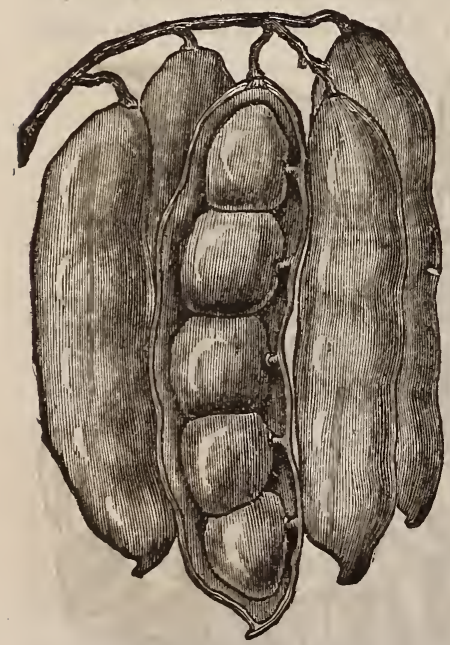

LARGE WHITE IIMA-One of the best shell beans. matures in go days. very popular. Our seeds are extra selected, large and fine. Pkt. Ioc., qt. 4oc. Mrailing, isc. qt.

KING OF THE GARDEN LIMA.-When green much larger in pod and bean than the Large White Lima ; vigorous, productive, handsome, popular. Pkt. Ioc., qt. $40 \mathrm{c}$. Mailing, I5c. qt.

DREER'S IMPROVED LIMA.-A smaller bean than the Large White Lima, but earlier, more productive and better quality. Pkt. Ioc., qt. 40c. Mrailing, I5c. qt.

HENDERSON'S BUSH LIMA.-(See page 2.) Pixt. Ioc., qt. 75c. Mailing, I5c. qt.

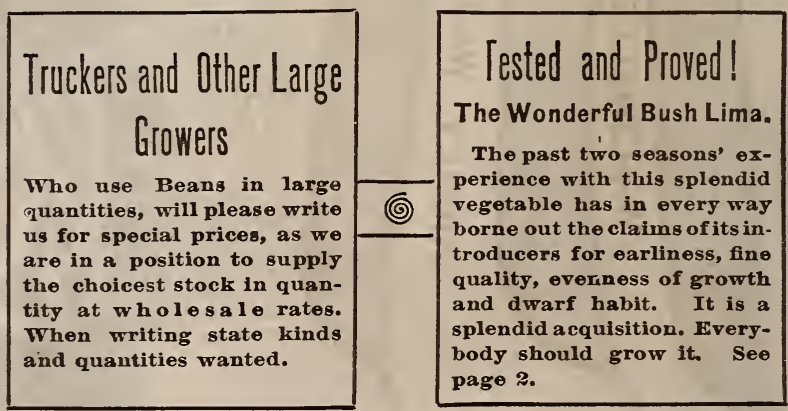

EXTRA EARLY JERSEY I,IMA. 


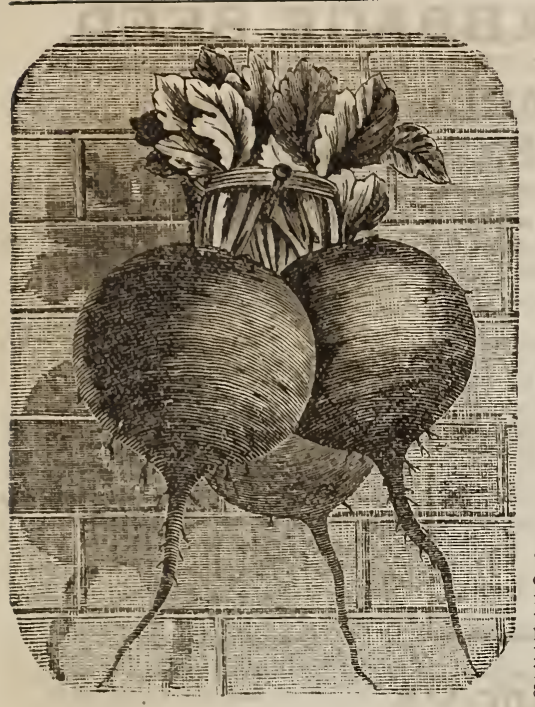

EXTRA EARLY ECLIPSE BEET.

\section{SELECT • TABLE • BEETS.}

\section{For Home Use or Market.}

EXTRA EARLY ECLIPSE.-Smooth, globe shaped, extra early, intense deep red, small top and root ; popular, profitable, tender, delicious. Ft. 5c., Oz, 10c., 1b, 6oc. Mailing, 8c, ib.

LENTZ EXTRA EARLY,-Round, smooth, very dark red, tender and sweet; a little larger than the Egyptian, fully as early and better quality; small top and fine keeper. A great favorite in the Philadelphia market, and one of the best round beets in cultivation. Pkt. 5c., oz. Icc., tb. 7oc. Mailing, $8 \mathrm{c} .1 \mathrm{~b}$.

EDMAND'S.-This new beet is very deep blood-red in color, and exceedingly sweet and tender in quality; very round and smooth in shape; of good niarketable size, not growing over large and coarse, as many sorts of the turnip beet are apt to do where they have plenty of room; highly recommended as second early market variety. Pkt. 5c., oz. 10c., 1b. 70 c. Mailing, 8c. 1b.

EGYPTIAN.-Flat turnip-shaped; extra early; deep red, tender and sweet. Pkt. 5c., oz. 1oc., 1b. 5oc. Nailing, 8c. 1b.

BASSANO.-Flat, turnip-shaped; light red; early ; popular. Pkt. 5c.,

Oz. IOc. 1h. 50C. MON TURNIP.-Good form, dark red, well flarored; a favorite for summer and winter use. Pkt. 5c., oz. 10c., 1b. $40 \mathrm{c}$. Mailing, $8 \mathrm{c}$. 1b. BASTIAN'S.Turnip-shaped,
extra early,light red ; popular, licious flavor. Pkt. 5c., oz. 10c. ib. 5oc. Maiiing, 8c. lb.

YELLOW TURNIP BEET.-Tender and good. Pkt. 5c., oz. roc., 1b. 65c., Mailing, Sc, 1b.

DEWINGS. - Turnip-shaped, early, blood red, good market sort. Pkt. 5c., oz. 1oc. 1b. 5rc. Mailing, 8c, 1b.

MPROVED LONG SMOOTH BLOOD.-Large, late, deep bloodswi popular, profitable, good. Pkt. 5c., oz. Ioc., 1b. 40 c. Mrailing, 8c. lb. leaves only the midribs of which are cooked like asparagus. Pkt. 5 c., oz. 1oc., ib. 5oc. Mailing, Sc. 1b.

FIELD BEETS AND MANGEL WURZEL.

For Stock Feeding, etc. (See Farm Seed Section.) BROCCOLI.

EARLY WHITE CAPE.-Heads medium, compact; creamy white. Pkt, Ioc., oz. $40 \mathrm{c}$.

EARLY PURPLE CAPE.-Greenish purple heads; hardy; good flavor. Pkt. 10c., oz. $40 \mathrm{C}$.

\section{BRUSSELS SPROUTS.}

IMPROVED DWARF.-The standard sort. Pkt. 5c., oz. I5c.

DALMENY PARK. - A hybrid between the Savoy Cabbage and Brussels Sprouts. Plt. 5 c., oz. 20 c.

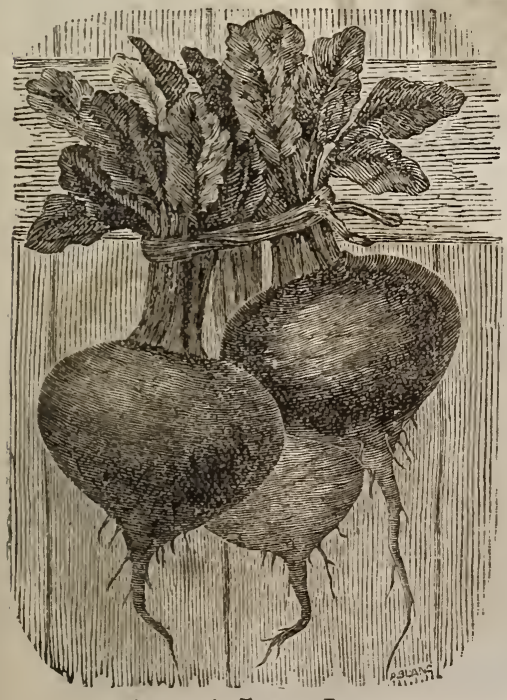

EDMAND'S TURNIP BEET.

SCRYMGEOUR'S GIANT. - Very compact, close headed variety. P'st. 5C., Oz, 2Cc。

\section{BORECOLE OR KALE.}

SCOTCH CURLY K.ALE. (Bonaccord Strain.)This is an extensively grown variety in Aberdeenshire, Scotland, where it reaches great perfection. It is a very distinct sort, half dwarf, and very curly. In vigor, hardiness, fine habit and handsome appearance, unsurpassed. Our strain of seed is true and extra select. (See colored illustration on cover.) Pkt. 5c., oz. I5c.

DWARF GREEN CURLED SCOTCH.Very hardy. a standard variety. may be treated like spinach. Pkt. 5c., oz. Ioc., ib. $80 \mathrm{c}$. Mailing 8c. $1 b$.

TALL GREEN CURLED SCOTCH.-One of the best. Pkt. 5c., oz. Ioc., 1b. 8oc. Mailing $8 \mathrm{c} .1 \mathrm{~b}$.

SIBERIAN OR GERMAN.-Sorv in fall for spring use; treat same as spipach. Pkt. $5 \mathrm{C}$, oz, Ioc, lb, 9oc, Mailing, Sc. $1 \mathrm{~b}$.

VARIEGATED.-For garnishing; very or namental. Pkt. 5C., oz. $25 \mathrm{C}$.

DWARF GREEN ERFURT.-Light green, very fine. Pkt. 5c., 02. 25 C.

DWARF BROWN.- Very hardy. Pkt. 5c., OZ. $20 \mathrm{C}$

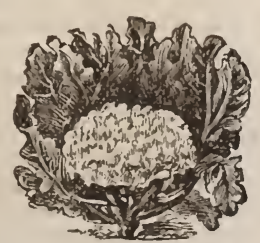

EARLY White CAPE BROCCOLI.
IMPROVED DWARF BRLS. SPROUTS. 


\section{TESTED RELIABLE CABBAGE SEED.}
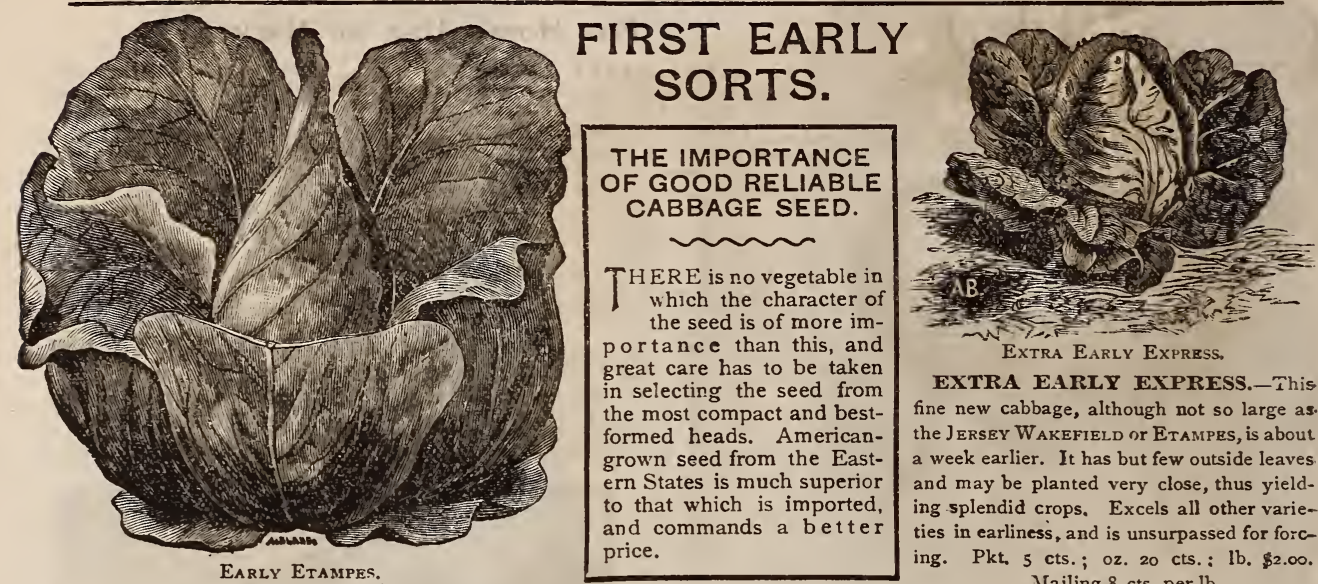

EXTRA EARLY EXPRESS. - This fine new cabbage, although not so large as the JERSEY WAKEFIELD or ETAMPES, is about a week earlier. It has but few outside leaves and may be planted very close, thus yielding splendid crops. Excels all other varieties in earliness, and is unsurpassed for forcing. Pkt. 5 cts.; oz. 20 cts.: lb. $\$ 2.00$. Mailing 8 cts. per $\mathrm{lb}$.

\begin{abstract}
GOOD SEED;
Deep, rich soil; plenty of manure; thorough cultivation. These are the cardinal points in raising a good crop of cabbage. Our cabbage seeds are saved with scrupulous care from the best selected heads and are second to none in quality.
\end{abstract}

\section{SECOND EARLY SORTS.}

Henderson's Early Summer-A littie later than W AKEFIELD; larger; more globeshaped; good header; rarely bursts; popular. Pkt. 5 cts.; oz. 25 cts.; lb. $\$ 2.00$. Mailing $\delta$ cts. per lb.

Early Winningstadt. Large; conical; sure header; succeed well on all soils. Pkt.

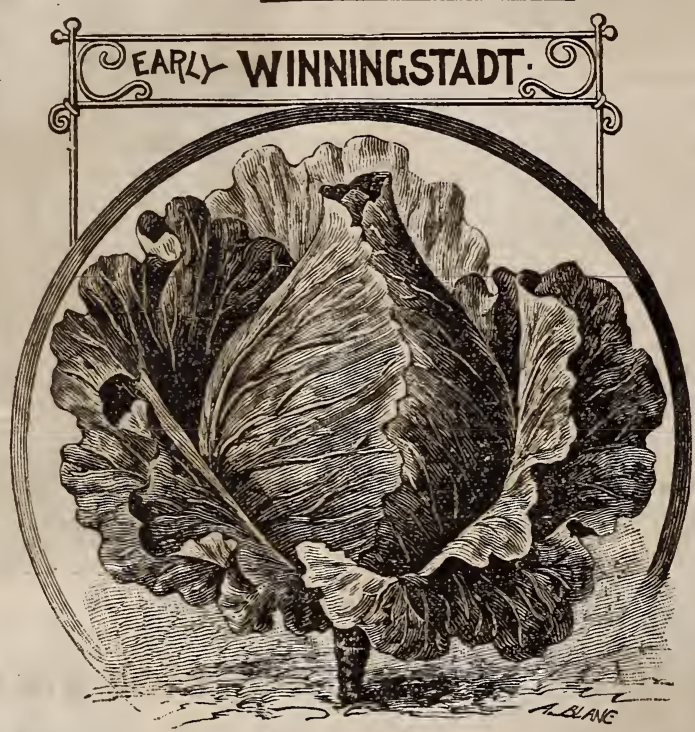

Early Etampes.-A very fine heart-shaped early cabbage. Pkt. 5 cts.; oz. 20 cts.; lb. \$r.75. Mailing 8 cts. per lb.

Early Jersey Wakefield. - The standard early; conical in shape; medium-sized heads; very solid; few outside leaves. Our seeds are saved. from carefully selected heads and is very choice stock. Pkt. 5 cts.; oz. 25 cts.; lb. $\$ 2.00$. Mailing $8 \mathrm{cts}$. per $\mathrm{lb}$.

Early French Oxheart. - An early variety of good size and shape; hard solid heads. Pkt. 5 cts.; oz. 15 cts.; lb. \$r. $\infty$. Mailing 8 cts. per lb.

Early Paris.-A favorite early of the gardeners who grow for the Paris market; oxheart in shape. Pkt. 5 cts.; oz. 20 cts.; lb. 75 cts. Mailing 8 cts. per $1 \mathrm{~b}$.

Early York.-A wellknown popular early sort. Pki, 5 cts. ; oz. 20 cts.; lb. \$1.75. Mailing $8 \mathrm{cts}$. per lb.

cts; oz. 15 cts.; lb. \$r.45.. Mailing 8 cts. per lb.

Large Early Schweinfurt.-A large early sort ; excellent for summer and fall. Pkt. 5 cts.; oz. 20 cts.; lb. \$r.75. Mailing 8 cts. perlb.

Filderkraut.-Larger than WiNNINGSTADT; more conical and has few outside leaves; a favorite for "kraut." Pkt. 5 cts. ; oz. 20 cts.; lb. $\$$ I. 75 . Nailing $8 \mathrm{cts}$. per $\mathrm{lb}$.

Fottler's Brunswick. - The earliest of the large heading Drumhead section; small stem; sure header; very popular. Pkt. 5 cts.; 02.25 cts.; lb. $\$ 2 . \infty$. Mailing $8 \mathrm{cts}$. per lb.

Newrark Eariy Flat Dutch.-Perhaps the finest strain of second early in cultivation; large solid heads; very popular among truck farmers. Pkt. 5 cts. ; 0z. 25 cts.; lb. \$2.00. Mailing 8 cts. per lb.

All Seasons.-As early as Henderson's Summer; larger head's and good for late as well as early ; solid; handsome; extra fine. Pkt. 5 cts.; cz. 25 cts.; lb. \$2.00. Mailing 8 cts. per lb.

LARGE RARLY LONG ISLAND WAKEFIELD. - This fine strain is not only the largest Wakefield in culivation, it is equally as early as the eariiest Jersey $W$ akefield and a most reliable header. The heads are not so pointed as the Jersey type, partaking more of the rounded form from having been crossed with the Flat Dutch for size. Highly recommended. Pkt. Io cts.; oz. $40 \mathrm{cts}$; l lb. $\$ 3.00$. Mailing $\delta \mathrm{cts}$ per lb.

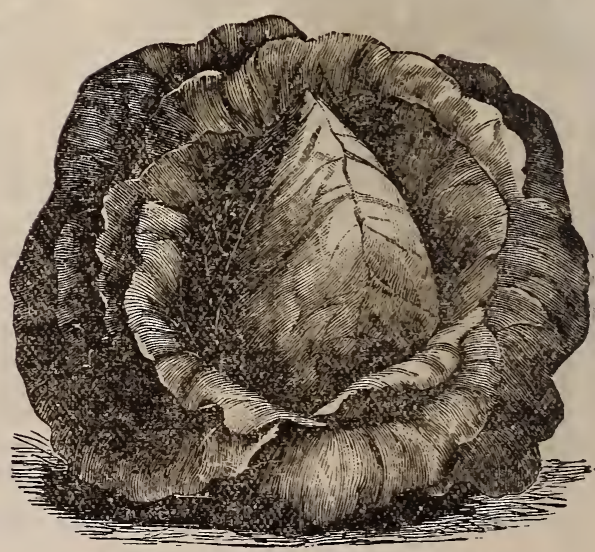

Nbw Large Early Long Island Wakefirld. 


\section{TESTED RELIABLE CABBAGE SEEDS.}

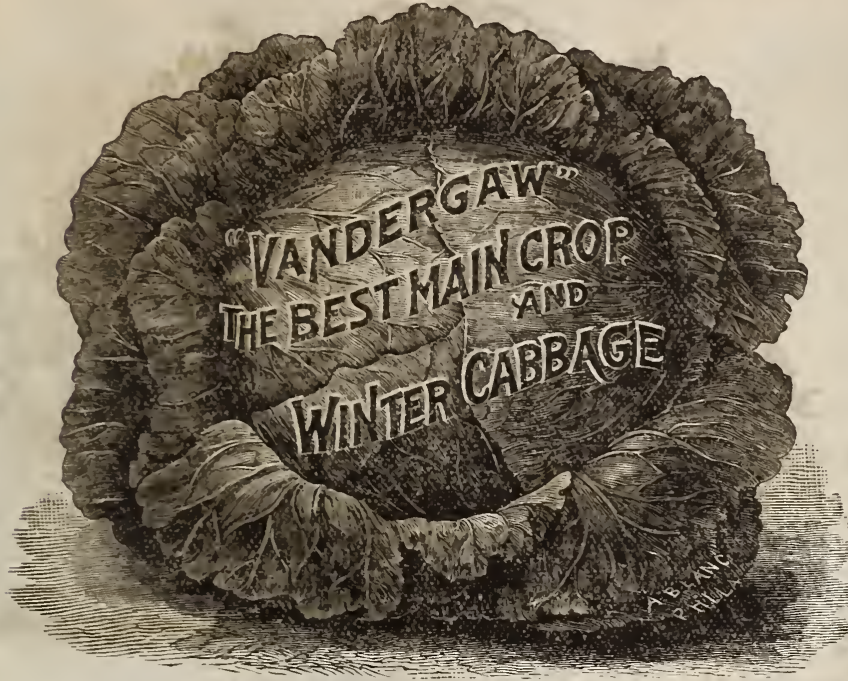

LATE SORTS.

STONEMASON DRUMHEAD.-ABOU a week earlier than Premium Flat Dutch large; solid; sure header. Pkt. 5c., oz 20c., 1b. \$1.75. Mailing, Sc. 1b.

PREMIUM FLAT DUTCH.-Excellent winter sort ; large; sure header; popular profitable. One of the very best late ca: bages. Largely grown in the south. Pkt. 5c., oz. 2oc., 1b. \$1.75. Mailing, 8c. 1b.

VANDERGAW.-For a main crop and late cabage this variety is unrivalled. Heads large, deep green, very tender, crisp and delicious; hard heading; reliable. Plkt. IOc., oz. 35c.

HYDE PARK. - A selection from Flat Dutch ; medium to late; very large, deep head, sightly rounding; fine texture rarely bursts. A reliable variety for bury ing over winter. Excellent either fo: market or home use. Plt. Ioc., oz. 35

AUTUMN KING - We believe this to be one of the finest strains of late cab bage ever offered. It produces regula: even heads, of enormous size; is a maz nificent cropper, has few outer leaves, and will give 99 out of every 100 large. solid, hard heads. We can thoroughly recommend this as one of the most satisfactory late cabbages in cultivation. Pist I5C., oz. $75 \mathrm{c}$.

\section{SAVOY CABBAGES.}

EXTRA EARLY PARIS.-A new French strain; very fine quality and beautifully crimpled; early; solid; one of the best. Plt. 5c., 0z. 20c., 1b. \$I.75

Mailing, 8c. 1b. quality. Pkt. 5c., Oz. I5C., lb. \$1.40. Mailing, 8c. 1b.

AMERICAN IMPROVED.-Sweet, tender, sure header; very popular. Pkt. 5c., oz. 25c., 1b. $\$ 2.00$. MIailing

Drumhead.-A standard late sort: fine quality; hard header and good keeper. Plt. 5c., oz. 20c., 1b. \$1.75. Mailing $8 c$.

MIDSUMMER SAVOY. -This is a distinct and useful sort, being but little later than the Early Clm, and pro-ducing heads of nearly double the size. The heads are beautifully netted, and are of a delicate light green color; a handsome new sort, hard heading and excellent. Pkt. Ioc. oz. $35 \mathrm{c}$.
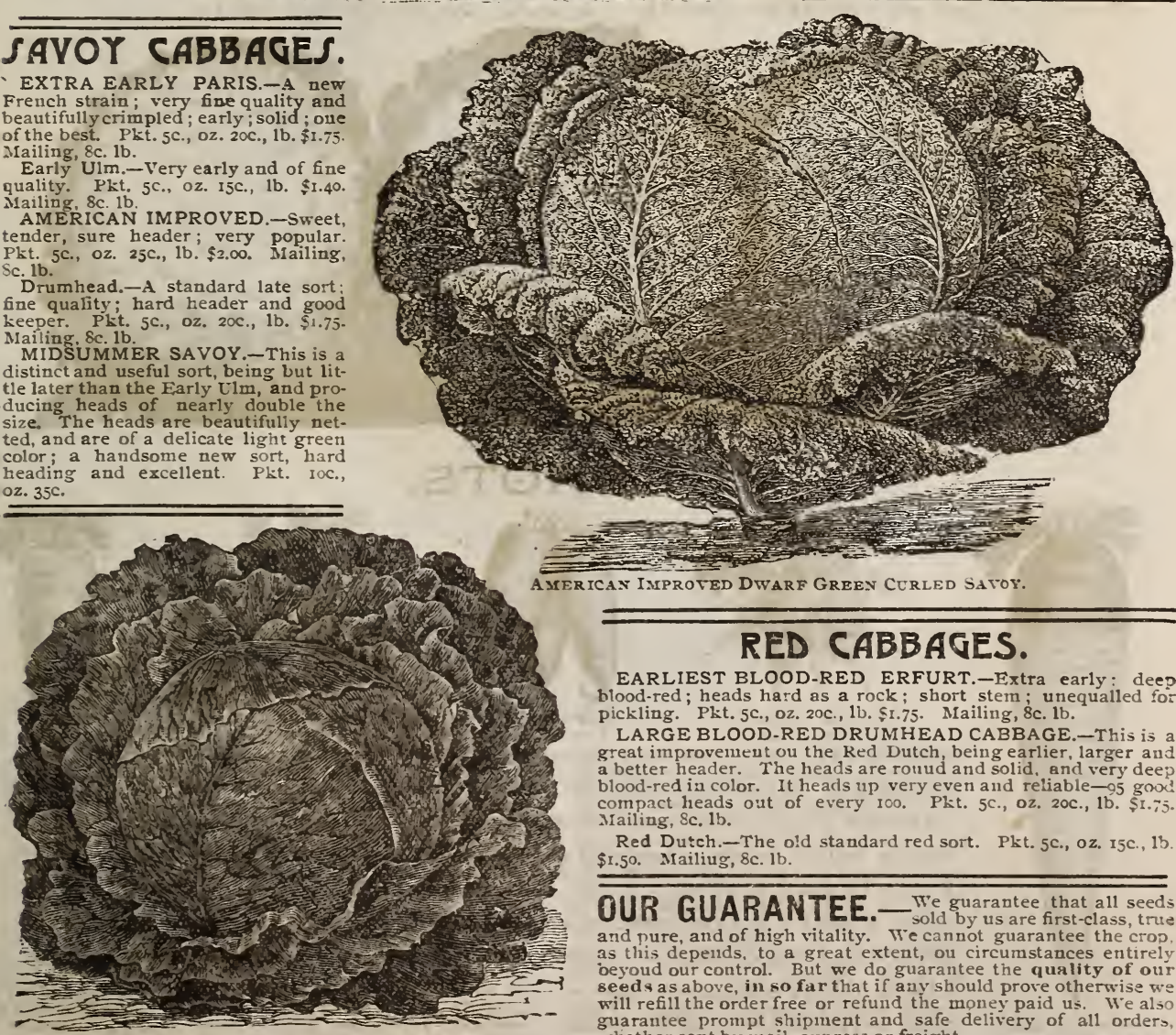

LARGE RED DRUMHEAD.

\section{RED CABBAGES.}

EARLIEST BLOOD-RED ERFURT.-Extra early: dee? blood-red; heads hard as a rock, short stem. unequalled fo pickling. Pkt. 5c., 0z. 20c., 1b. \$1.75. Mailing, 8c. 1b.

LARGE BLOOD-RED DRUMHEAD CABBAGE.-This is a great improvement ou the Red Dutch, being earlier, larger and a better header. The heads are round and solid, and very deep blood-red in color. It heads up very even and reliable- $95 \mathrm{groc}$ compact heads out of every 100, Pkt. 5c., 0z, 20c., lb. 5I.7. Mailing, 8c, $1 \mathrm{~b}$.

Red Dutch.-The o!d standard red sort. Pkt. 5c., oz. I5c., 1b. \$1.50. Mrailiug, $8 \mathrm{c}$. 1b.

OUR GUARANTEE. - We guarantee that all seed and pure and of high vitality We cannot are first-class, true as this depends, to a great extent, ou circumstances entirel beyoud our control. But we do guarantee the quality of our seeds as above, in so far that if any should prove otherwise we will refill the order free or refund the money paid us. We also guarantee prompt shipment and safe delivery of all orders whether sent by mail, express or freight.

JOHN GARDINER \& $C O$. 


\section{$\checkmark$ QACULIFLOUER D.}

EXTRA EARLY DWARF ERFURTVery Choice Quality. - There can be little doubt that this is the best cauliflower either for forcing under glass or for the open ground. Large size snowy white open ground. Large size, snowy white crops that depend so much on the quality crops that depend so much on the quality of the seed as cauliflower, and although there is great temptation to save a dollar,
we advise buying the best. Pkt. 20c., I/ oz. \$1.50.

Early Dwarf Erfurt.-Good quality. A fairly good strain of Erfurt at a moderate price. Pkt. Ioc., Oz. $\$ 1.50$,

VEITCH'S AUTUMN GIANT Firm, compact heads; snowy white; a good keeper; large and vigorous. Pkt. IOc., $0 z .65$ c., $1 / 1 / 1 \mathrm{~b}$. $\$ 2.00$.

EARLY PARIS.-Half-early variety, or forcing. Pkt. Ioc., oz. 5oc., 1/4 1b. $\$ 1.75$. LENORMAND'S SHORT STEM.Large heads, white and firm. Pkt. Ioc., oz. $75 \mathrm{c}$., $1 / 1 / 1 \mathrm{lb} . \$ 2.25$.

LATE ALGIERS.-Firm, solid heads; good for late use. Pkt. Ioc., 0z. 75c., 1// 1b. WALCHEREN,-Very late and hardy. firm, close-grained heads. Pkt. Ioc., oz. $75 \mathrm{c},{ }^{1 / 1} 1 \mathrm{~b}, \$ 2.00$.

TRUE EARLY SNOWBALL CAULIted, and by many is preferred to all others. Very early, a sure header; grows very close and compact. Heads of snowy whiteness, and average about nine inches

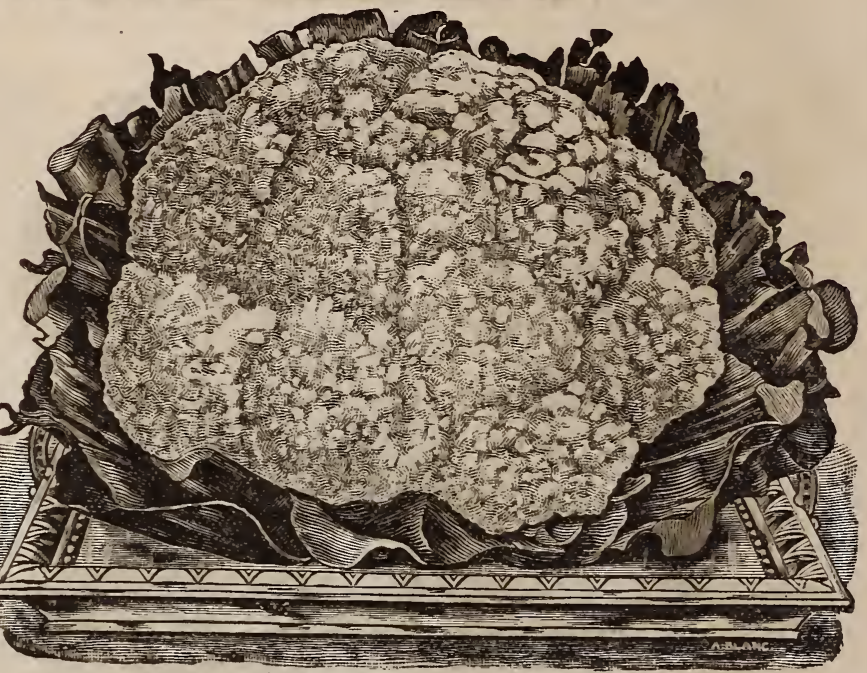

EXTRA EARLY DWARF ERFURT.

with small outer leaves, which makes it well adapted for close planting. Plt. 20c., $1 / 4$ oz. $\$ 1.00,1 / 20 z$. $\$ 1.75,0 z . \$ 3.25$.

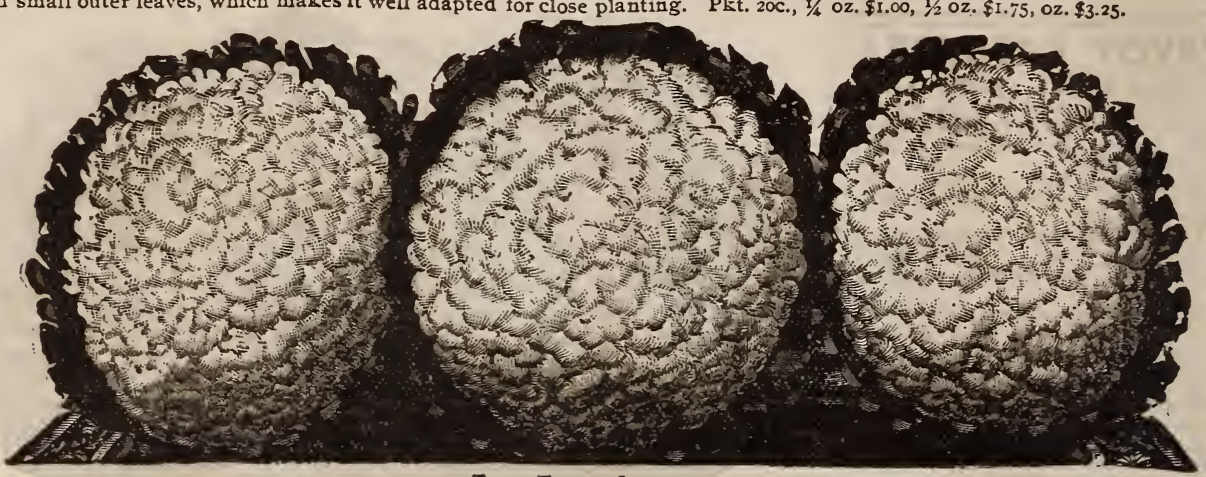

TRUE EARLY SNOWBALL.

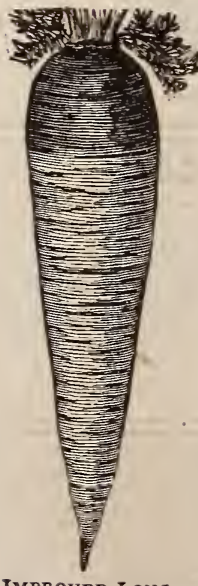

CARROTS.

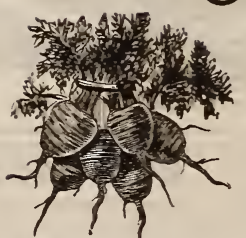

EARLY FREXCH
FORCIXG CARROT

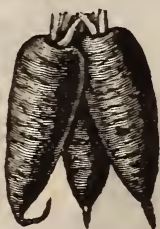

DANVERS HALF

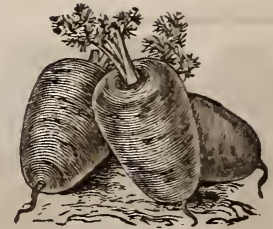

GLERANDE CARRot

CHANTENAY. - The favorite early market carrot of Paris; half-long; stump-rooted, moother and sweeter than Danvers, very small core. Pkt. 5c., oz. roc., 1b. 7oc. Mailing, 8c. lb. GUERANDE- - New stump-rooted carrot; thick and short; fine color and flavor; the eaviest cropper of the early sorts. Pkt. 5c., oz. Ioc., 1b. $8 \mathrm{oc}$. Mailing, $8 \mathrm{c}$. 1b.

DANVERS HALF-LONG.-Smooth, handsome variety; very dark in color; good cropper: keeps well : first-class carrot in every way. Pkt. 5c., oz. 10c., lb. 7oc. Mailing, 8c, 1b.

EARLY SHORT HORN.-Small, early sort; fine color; good for bunching for market ; an be planted verv close. Pkt. 5c., oz. Ioc., lb. $70 \mathrm{c}$. Mailing, $8 \mathrm{c}$. $1 \mathrm{~b}$.

EARLY FRENCH FORCING.-The earliest variety grown; small, tender, delicious. Pkt. c., oz. Toc., lb. 8oc. Mailing. 8c. 1b.

LONG SCARLET ALTRINGHAM.-A standard variety both for cooking and stock. Pkt. IMPROVED LONG ORANGE. -Very large; main crop carrot; heavy yielder. Pkt. 5c., oz. roc., 1b. 5oc. Mailing, 8c. 1b.

LARGE WHITE BELGIAN.-Grows one-third out of ground; root white, green above

ground; grown extensively for stock. Plt. $5 \mathrm{C}$., Oz. IOc., 1b. $40 \mathrm{co}$. Mailing, 8c. 1b. ORANGE CARROT. tapers from shoulder to tip ; fine quality; very productive. Pkt. 5c., oz. ioc., lb. 7oc. Mailing, 8c. Ib.

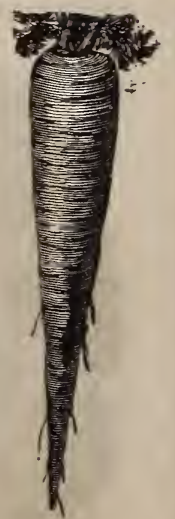

SCARLET CARROT. 


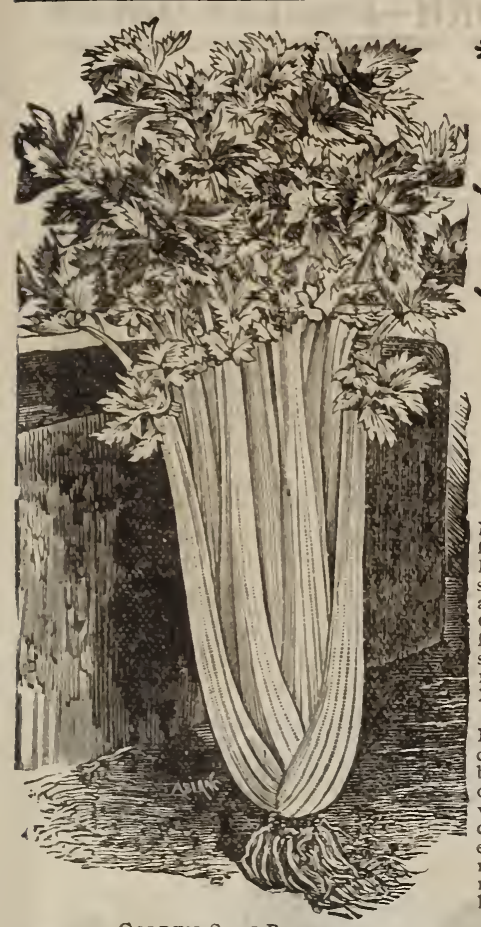

Gorden SELF-BLANCHING.
*GARDINER'S*

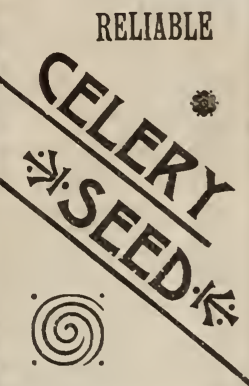

GIANT GOLDEN HEART CELERY.-A ine selection froin the Dwarf Golden Heart; large size, beautiful color, crisp and delicionsly flavored. One of the best celeries for market, and also desirable for home use. Pkt. IOC., Oz. 50c., 1b. $\$ 3.00$. Mailing, 8 c. $1 \mathrm{~b}$

GOLDEN SELF BLANCHING. - Close, compact, handsome; heart beautiful golden-yellow, outer stalks yellowishwhite, ribs perfectly solid,
crisp, well flavored, and excellent keeper; very fine new celery, highly recommended. Pkt. $5 \mathrm{c}$., oz, $40 \mathrm{C}$., 1b. \$3.50. Mailing, Sc. lb. SELF-BLAN C H ING-

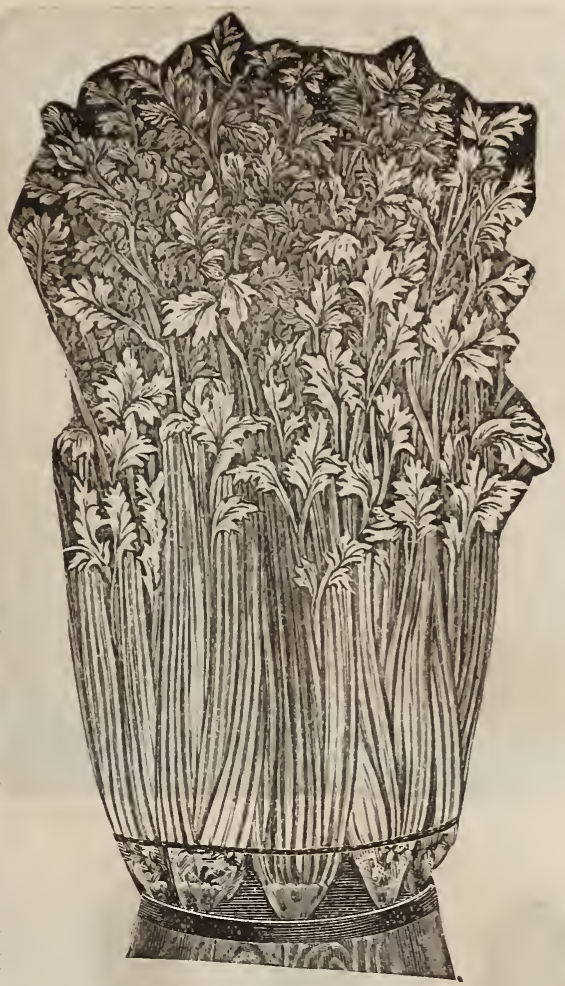

GIANT GOLDEN HEART.

SOLID IVORY.-Dwarf compact habit, and beautiful white color ; solid, crisp and delicious. Pkt. $5 \mathrm{C}$., Oz. $30 \mathrm{c}$. largest and best winter sort, solid and vigorous. Pkt. $5 \mathrm{C} .$, OZ. $35 \mathrm{C}$.
SANDRINGHAM DWARF WHITE. - The dwarfest white variety, solid and crisp. Pkt. 5C., Oz. 25C.

BOSTON MARKET - The popilar favorite in the Boston market, dwarfbranching habit, solid, crisp, well flavored. PKt. 5C. OZ. 25C.
CELERY SEED.-For flavoring CELERIAC.

Turnip-Rooted Celery. APPLE - SHAPED.
-New, almost round, smooth, and handsome. Pkt. 5C, oz. $25 \mathrm{c}$.
GIANT.-Very large.
Ptst. 5c., oz. $25 \mathrm{c}$.

\section{CARDOON.}

LARGE SOLID - GrOW height, leaves almost free fi mi spines. Pkt. Ioc.,
oz. $40 \mathrm{c}$.

\section{CHER VIL.}

- CARDOON

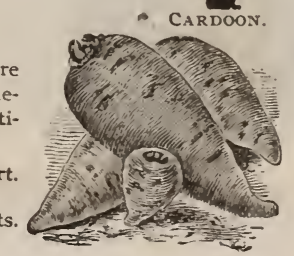




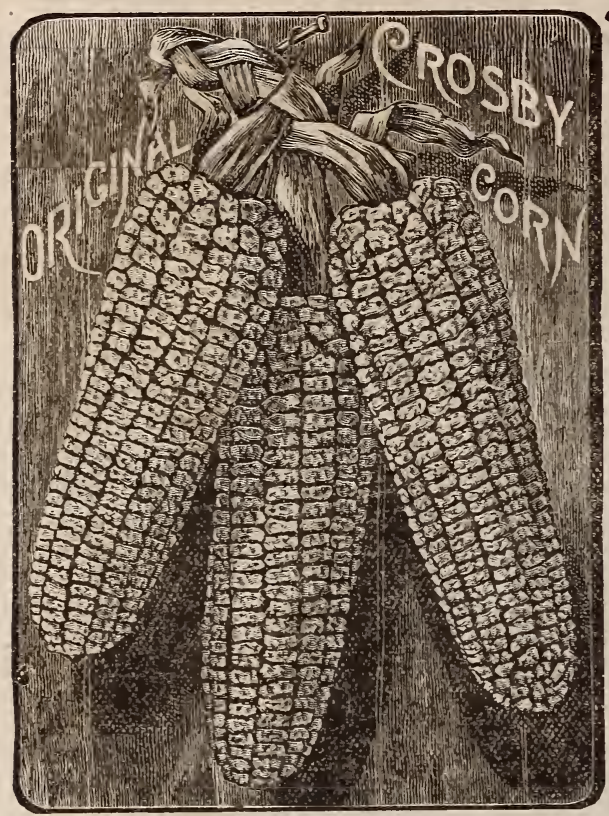

SWEET CORN-Selected Eastern-Grown Seeds.

Our Sweet Corn is all Eastern-grown and is sweeter, earlier and more vigorous than Western-grown seed.

EARLY CORY.-An extra early variety with good-sized ears and large kernels. Pkt. roc., qt. 25c. Mailing. 15c. qt. early sweet corns: twelve-rowed. dwarf habit; ears set very low and of good size, cob white. There are many inferior strains of this on the market ; ours is the true original Crosby from the originator's stock. Pkt. Ioc., qt. 25c. Mailing, I5c. gt.

PERRY'S HYBRID.-Very early and of large size; good for market. Pkt. Ioc., qt. $25 \mathrm{c}$. Mailing, 15c. qt.

AMBER CREAM.-Nedium early; large, sweet, handsome. Plkt. roc., qt. 25c. Mailing, 15c. qt.

PEE-AND-KAYY.-Medium early; large thick ears; tender and sweet. Pkt. Ioc., qt. 25c. Mailing, 15c. qt.

POTTER'S EXCELSIOR. - The sweetest medium early sweet corn ; twelve-rowed, white prolific, handsome; requires a liberal seeding. Pkt. IOc., qt. 25c. Mailing, 15c. qt.

EARLY MARBLEHEAD. -A good, earlycorn; medium EARLY size; prolific; a week later than Cory. Pkt. Ioc., qt. 25c. MARBLE-

EARLY MINNESOTA.-An early sort, of dwarf habit ears sizall; excellent, productive. Ptat. Ioc., qt. 25c. Mailing, I5c. qt. than Crosby; ,twelve-rowed, excellent. Pkt. roc., qt. $25 \mathrm{c}$. Mailing. Sc. qt. size; extremely sweet; the dark color does not show prominently in the green state its great merit is its prometness. Pkt. Ioc., qt. 25c. Mailing, I5c. qt.

EGYPTIAN. Ioc., qt. 25c. Mailing, 15c. qt. much sweeter; largely used for canning. Plt. roc., qt. $25 \mathrm{c}$. Mailing, I5c. qt.

STOWELL'S EVERGREEN.-The standard late sort; large ears, sweet; remains long green; the stalks are valuable for fodder. Pkt. roc., qt. $25 \mathrm{c}$. Mailing, 15c. qt.

MAMMOTH SWEET SUGAR.-A late variety, with ery large ears and extra sweet flavor. Pkt. Ioc., qt. 25c. PEE-ANDMailing, 15c. qt.

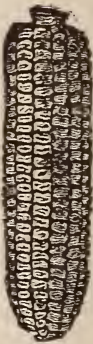

PERRY'S HYBRID.

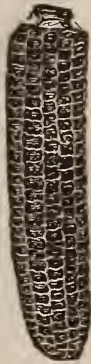

BLACK

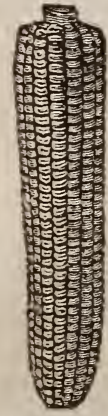

MAMMOTH

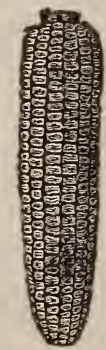

POTTER'S

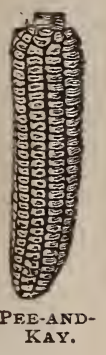

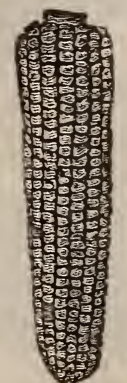

STOWELL'S

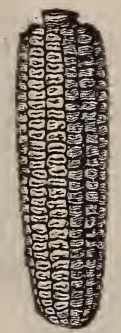

MOORE'S

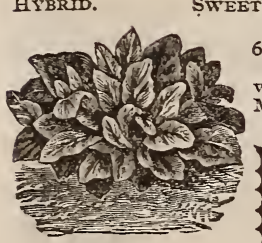

CORN SALAD.

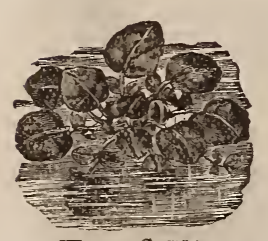

WATER CRESS.

TVATER CRESS.

This is the famous English Water Cress; requires to be planted along the borders of shallow water courses. Pkt. roc., Oz. 40c., 1b. \$2.75. Mailing, 8c. 1b. Mailing, 8c. $1 \mathrm{~b}$.

SWEET CORN. prices.

CORN SALAD-Large Seeded.-The standard variety ; one of the best salads. Ready for cutting in 6 weeks. Treat as spinach. Pkt. 5 c., oz. Ioc., 1b. $60 c$. Miailing, $8 c .1 b$. hen

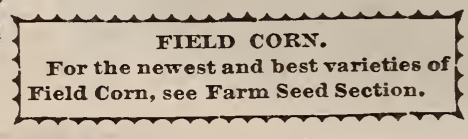

Special Rates to Truckers and Canners.

To Truckers, Canners and others who use sweet corn in large quantities special rates by the bushel. Quotations for the asking. State kinds and quantities when writing for

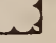

UPLAND

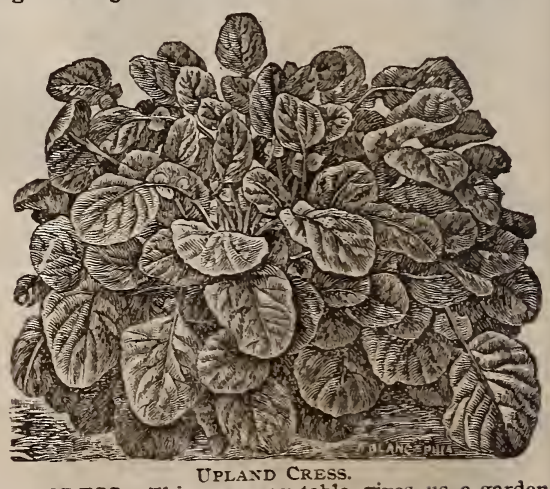

RESS.-This new vegetable gives us a garden substitute for the English Water Cress. Crisp, tender, perfectly pungent flavor of water cress. Pkt. Ioc., 3 pkts. $25 \mathrm{c}$. 
CUCUMBERS.

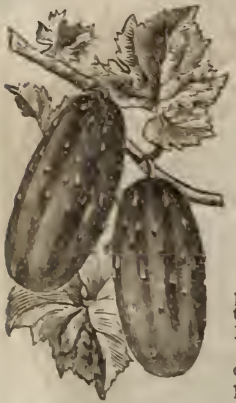

IMPROVED WHITE SPINE CCCUNBBR.

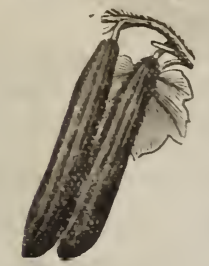

ENGLish FRAME C CUBER "TELE-

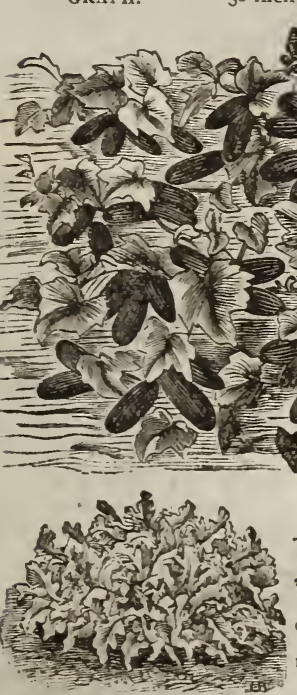
White CURLED ENDIVE.

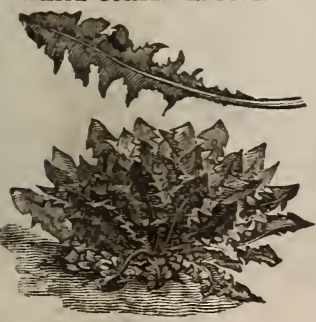

Moss Cirled DANDELYON.

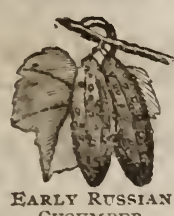

CUCTMBER. the White Spine

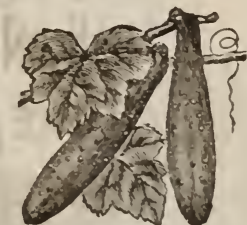

NICHOL'S MEDICY

SPECIAL RATES TO CANNERS ANI LARGE GROWERS FOR MARKET.

$\Delta$

NICHOL'S MEDIUM GREEN. - An early cucumber: good for forcing or pickles : dark green ; crisp : very prolific, straight and smooth ; in length between

TAILBY'S HYBRID.-A cross between White Spine and an English Frame variety, with the hardiness of the former and the beauty and size of the latter; very prolific; one of the finest. Pkt. 5c., oz. 10c., 1b. 75c. Mailing, 8c. 1b.

EARLY RUSSIAN.-A small variety; the earliest grown; Io days ahead of EARLY IOREEN CLUSTER.-Tery early, fruits in clusters; short, prickly, very

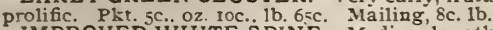

IMPROVED WHITE SPINE.-Medium length, dark green, crisp, well flavored, Mrolific. One of the most popular varieties grown. Pkt. 5c., oz. 10c., 1b. 65c. EARLY FRAME.-Early, medium length, good for forcing. Pkt. 5c., oz. roc., IMPROVED LONG GREEN. - Tery popular, late variety, dark green, crisp, tender and well fiarored. Pkt. 5c., oz, 10c., 1b.65c. Mailing, 8c, 1b.

BOSTON PICKLING.-One of the best varieties for pickling ; short, straight, dark green, fine quality, great bearer. Our strain of seed is true Arlington Stock. WEST INDIA GHERKIN.-A small green pickling sort, used for pickling only Pkt. 5c., oz. 10c., 1b. \$1.15. Mailing. 8c. 1b.

ENGLISH FRAME CUCUMBERS.-These are grown in the green-house, o in a hot-bed; very handsome both in form and color: attain a length of from 20 to inches. The following are the cream of the many popular sorts:

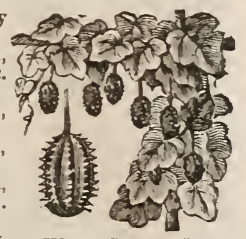

WEST INDIA GHERKIN CCCLMBBER.

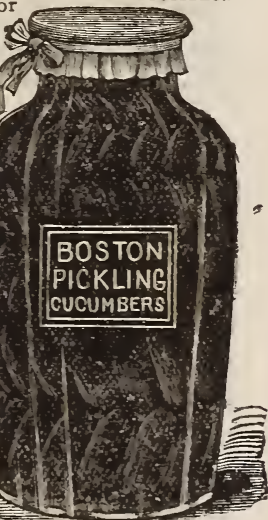

Blue Gown, Marquis of Lorne, Telegraph, Tender and True, Duke of Edinburgh, Sion House Improved, Lord Kenyon. Each per packet, $25 \mathrm{c}$

DDIVE GREEN CURLED.-One of the best: dark NDIVE. GREEN CURLen, finely curled. Pkt. $5 \mathrm{c}$., oz. $20 \mathrm{cos}, 1 \mathrm{~b}$. WHITE CURLED.-Pale green, very handsome. Pkt. 5c., MOSS CURLED.-Beautifully and densely curled, very ornamental. Pktt. 5c.. oz. Ioc..1 1b. \$1.65. Mailing, 8c. $1 \mathrm{~b}$.

BATAVIAN BROAD-LEAVED.-A large summer variety, very productive. Pkt. 5c., oz. 20c., ib. \$1.65. Mailing, 8c. 1b.

DANDELION THICK-LEAVED FRENCH. leaved, crisp, fine flavored. Pkt. 5c., oz. 25c

AMERICAN IMPROVED. - A very superior variety crisp, fine flavored. Plt. IOC., oz, $50 C$

IMPROVED MOSS-CURLED.-Leaves deeply cut and finely curled; crisp and excellent. Pkt. Ioc., oz. 5oc.

EGG-PLANT. EARLY DWARF PURPLE. LONG PURPLE.-Early dearly. Plte. 5c, oz., 30c. productive, excellent; color variable. Pkt. 5 c., Oz. $25 \mathrm{c}$ BLACK PEKIN.-Fruit blackish-purple, globe-shape

NEW YORK IMPROVED. - One of the best, very large, fine quality. Plst, IOC, Oz, $50 \mathrm{C}$

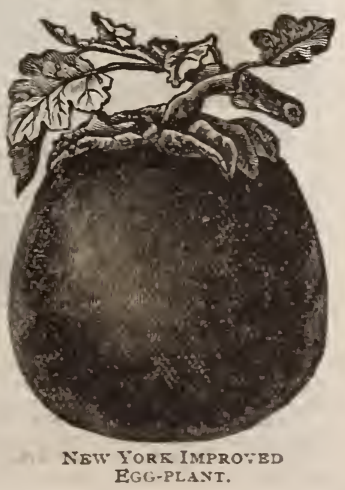




\section{$\triangle$ LETTUCE $\leadsto$}

HEAD LETTUCES.

BLONDE HARDHEAD LETTUCE (New)-A very fine new summer lettuce; exceedingly hard heads, of a bright golden yellow; crisp and tender; very attractive. A great heat-resisting sort, remaining sweet, tender, crisp and juicy when most other kinds have become tough and bitter. Very
distinct and sure to become a popular favorite. Pkt. Ioc., 3 pkts. $25 \mathrm{C}$

BUTTERCUP (New). - Early, hardheading, beautiful foliage, tender, and delicate flavor; good either for summer or winter. Pkt. 5c., oz. 2oc., 1b. \$I.75. Mailing, 8c. 1b.

NEW YORK MARKET.-Large solid head; outside leaves clear, deep apple green, inside leaves yellowish white blanches naturally and is slow to run to seed; flavor crisp and tender; entirely free from bitterness; a splendid sort for ummer use; one of the largest lettuces in cultivation. Pkt. 5c., oz. 20c., 1b. \$I.75. MIailing, 8c. 1b. for family use, being a great heat resister and remaining crisp and tender for a long time; heads light green and extra large. Pkt. 5c., oz. 20c., lb. \$1.75. Mailing, 8c, 1b.

Early Prizehead.-Very large ; fine flavored, crisp, tender; slow to seed. Pkt. 5c., oz. 20c., 1b. \$1.75. Mailing, 8c. 1b. HANSON.-Splendid out-door lettuce; heads very close, solid and large; crisp, tender, sweet; green outside, white within. Pkt. 5C., oz. 20c., 1b. \$1.75. Mailing, 8c, 1b.

SALAMANDER.-Yellow; very hard header; stands the summer well. Pkt. 5c., 27, 15c., 1b. $\$ 1.25$ Mailing, 8c. 1b.

Brown Genoa.-Medium round head, stained with red; good either for summer or winter. Pkt. $5 c, 07,25 c, 1 b . \$ 2.00$. Mail ing, $8 \mathrm{c}$. $1 \mathrm{~b}$.

DEACON.-A splendid variety for standing the summer heat large solid heads, tender, crisp and sweet; very popular. Pkt 5c., oz. 20c., 1b. \$I.75. Mailing, All the Year Round.-Hardy, heads firm, medium; does not run to seed readily; deep green, tender and crisp. Pkt. 5c., oz, $15 \mathrm{c}$., $1 \mathrm{~b}$. \$1.25. Mailing, 8c. 1b.

Marblehead Mammoth.-Very large, good quality, hard header slow to run to seed. Pkt. 5c., oz. 2oc., 1b. \$1.75. Mailing, 8c. 1b.

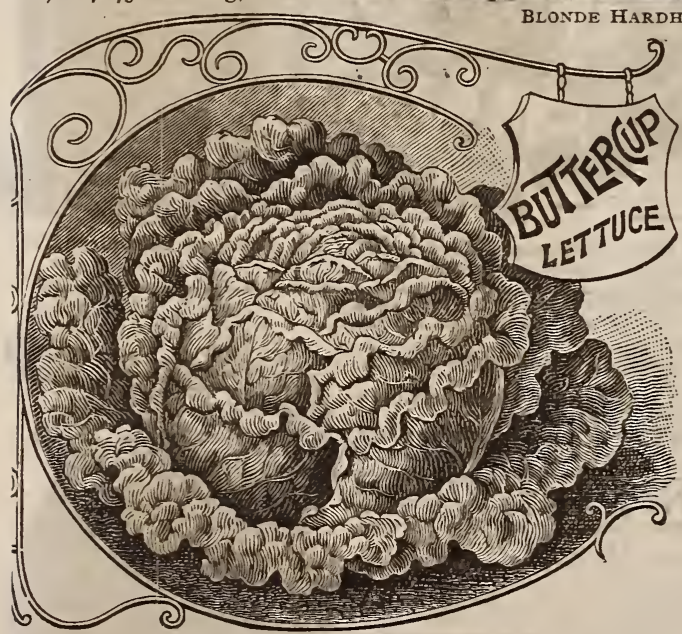

KOHL RABI.

The Kohl Rabi, when young is tender and delicate, possessing the flavor of both the cabbage and turnip. Cooking same as the ruta baga. Pkt. 5c., oz. 20c., 1b. \$1.90. Mailing, 8c. 1b. EARLY WHITE VIENNA.-Green top, white flesh, popular, handsome, good flavor. Pkt. 5c., oz. 20c.1b, \$1.90. Mailing, 8c. ib. EARLY PURPLE VIENNA.-Differs from the preceding only in color. 2kt. 5c., oz. 20c., 1b. \$1.90. Mailing, 8c. 1b.

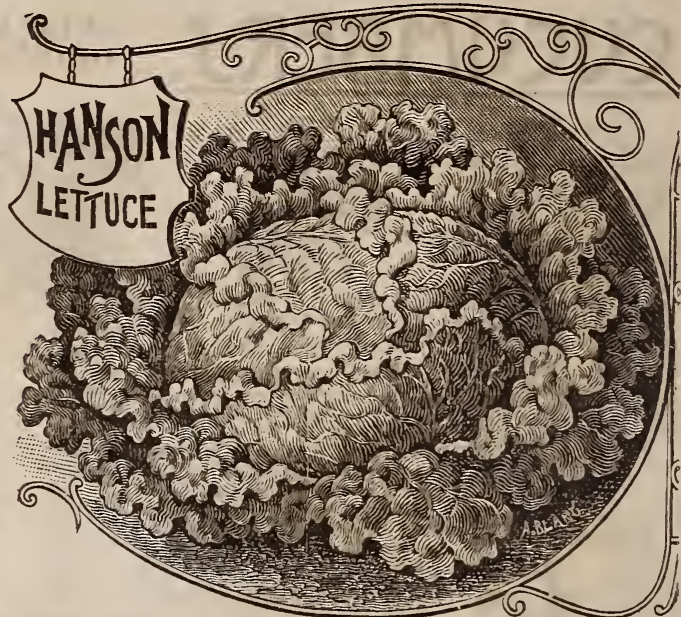

FORCING LETTUCES.

BOSTON MARKET.-A pOpular forcing variety; good size, solid, crisp and white. Our stock is pure Boston market, a great improvement over the White Seeded Tennis Ball. Pkt. 5c., oz. $15 \mathrm{c}$. 1b. \$I.25. Mailing, 8c. 1b.

Tennis Ball, Black Seeded.Solid, dark green heads; very hardy; one of the best either for out-doors or forcing; crisp and out-doors or forcing; crisp and
tender. Pkt. 5 c., oz. I5c., $1 \mathrm{~b} . \$ \$$. Mailing, \&c. 1b.

GOLDEN STONEHEAD.Small, solid; very handsome; splendid forcer: also stands the summer well for outside. Pkt. 5c., 0z. 20c., 1b. \$1.75. Mailing,

WHEELER'S TOM THUMB (New).-A small variety; very solid, crisp, and of unsurpasse Mailing, 8c. $1 \mathrm{~b}$.

\section{CURLY LETTUCES.}

Early Curled Simpson.-Yellowish green; early; very curly. Largely used for frame culture, and also for an early open-air sort between a cabbage crop. Pkt. 5c., oz. 20c., 1b.

\$1.40. Mrailing, 8c. 1b.
Early Curled Silesia.- Very early ; good either for forcing or open air. Pkt. 5c., oz. I5c., 1k. \$1.15. Mailing, 8c. 1b.

Boston Curled.-Deep rich greer; beautifully curled. early, tender, crisp i very ornamental for table. Pkt. 5c., oz. c., 1b. \$1.00. Mailing, 8c. 1b.

\section{UPRIGHT OR COS LETTUCE.}

Paris White Cos.-The best of the Cos varieties, with long upright leaves; blanches readily when tied up. Pkt. 5c., Oz. I5c., 1b. \$1.00. Mailing, $8 \mathrm{c}, 1 \mathrm{~b}$.

\section{LEEK.}

LARGE LONDON FLAG.-Hardy, fine quality, the most popular variety in this country. Pkt. 5 c., oz. 15 c., $1 \mathrm{~b}$.

9o. MUSSELBURGH.-Grows to immense size; broad leaves, light green, hardy, excellent. Pkt. 5c., oz. 20c., lb. \$I Mo. Mailing, 8c, Ib.

GIANT CARENTAN. - One of the best, short, thick, hardy, excellent. Pkt. 5c., oz. 20c., 1b. \$I.90. Mailing, 8c. 1b.

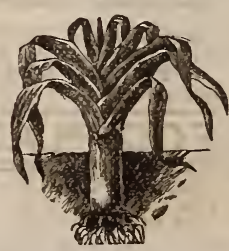

MUSSELBURGH LEEK.

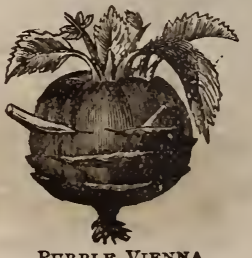

PURPLE VIENNA 


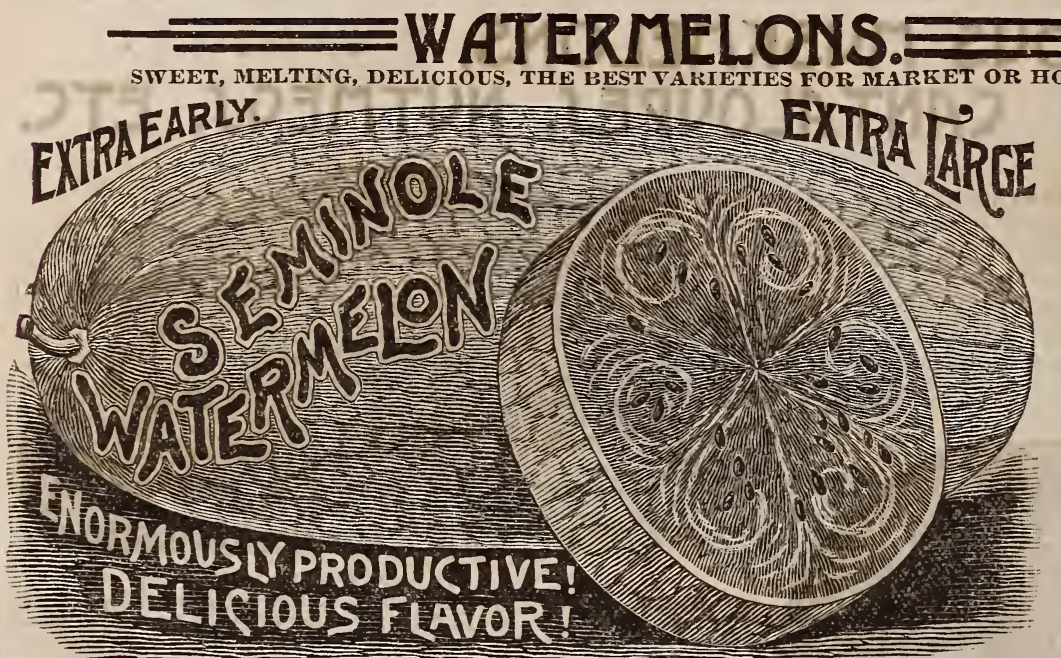

ME CSE.

SEMINOLE.-A new large of great merit, early and fine flavored. Pkt. 5 c., oz. Ioc. HUNGARIAN . $1 \mathrm{~b}$. NEY. - Large, round dark greein ; llesh brilliant red and deliciously sweet; grows very un sweet; grows very and productive. $\mathrm{Pkt}$ LONG LIGHT IC. ING. - (Syn. Jordan's Gray Monarch,) light green mottled, very large'; flesh deep red, splendid quality; on of the largest and finest melons. Pkt. 5 . oz. Ioc., 1b. goc. Mrailing, $8 \mathrm{c}$. $1 \mathrm{~b}$.

RUBY GOLD. - A beautiful new melon of extra fine quality; grows to a large size40 to $50 \mathrm{lb}$. average; early, very productive

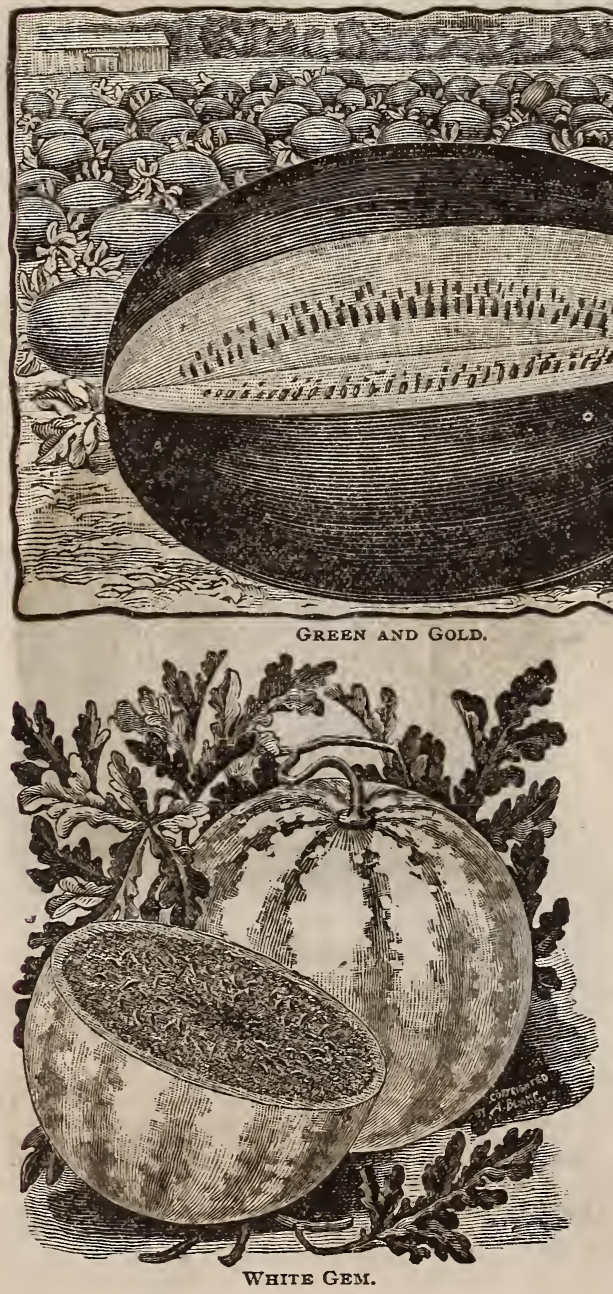

OEMLER'S TRIUMPH.-A new melon from Russia - very early, productive, short oval, weighs about 15 lbs., dark mottled green; flesh dark red, edged with orange, very sweet and luscious. Pkt. IOC. OZ. ${ }^{25 C}$. white stripes, flesh light crimson, crisp and deliciously sweet. Very early; one of the finest table melons grown, not a good shipper, owing to its thinness of rind. Pkt. 5c., oz. roc., 1b. $70 c$. Mailing 8c lb.

SCALY BARK. - Large, dark green, with scaly markings: rind thin and tough, an excellent shipper; flesh light crimson, rich flavor. Pkt. c., oz. Ioc., 1b. 65c. Mailing, 8c. 1b.

MAMMOTH IRONCLAD. - A very large variety, of excellent quality, oblong, green mottled; flesh bright red, crisp and delicious; a good
keeper and shipper. Pkt. 5c., oz. Ioc., 1b. $65 \mathrm{c}$. Mailing, Sc. OF. GEORGIA.-Large, ova1, dark green; flesh deep red, crisp and sweet; a good shipper. Pkt. 5c., oz. 1oc., 1b. 65c. Mailing, 8c. 1b. BOSS.-An early, oblong variety; flesh deep scarlet, rich and sweet. Pkt. 5c., oz. 1oc., 1b. 65c. Mailing. 8c, 1b. $\mathrm{b}$. RIND. rind; flesh rich, sugary, melting, an excellent sort; Pkt. rich, sugary, melting, an excellent GREEN AND GOLD. - The earliest and best yellow fleshed variety; early, productive, fine flavor. Grows to good size, ranging from 25 to 35 lbs. A valuable acquisition. Pkt. 5c., oz. Ioc., 1b. goc. Mailing, $8 \mathrm{c}$. $1 \mathrm{~b}$

WHITE GEM.-A new round white melon of medium size rind thin, but very tough : flesh pink, crisp; very sweet, and delicious flavor; hardy, productive, good shipper. Pkt. Ioc., oz. 25c. KOLB'S GEM - Light green, nearly round, averaging 30 to 50 lbs. in weight; flesh bright red, rich and sweet; a good shipper. Pkt. 5c., oz. Ioc., 1b. 65c. Mailing, 8c. 1b.

MOUNTAIN'SWEET. -An old favorite for northern growing, long, dark green : flesh, very solid, crisp and sweet. Pkt. 5c., oz. Ioc., 1b. 5oc. Mailing, 8c. 1b.

CUBAN QUEEN. - Very large, enormously productive; vigorous, healthy, and an excellent keeper; flesh bright crimson, solid, rich, and sugary. Pkt. 5c., oz. 10c., 1b. $65 \mathrm{c}$. Mailing, 8c. 1b.

RATTLESNAKE.-Large, obiong, striped and mottled. flesh bright red; a good shipper; a favorite variety in the south. Pkt. $5 \mathrm{C}$., z. Ioc. 1b. $60 \mathrm{c}$. Mailing, $8 \mathrm{c}$, lb.

VICK'S EARLY.-A splendid early sort; flesh bright red ; solid, sugary and luscious. Pkt. $5 \mathrm{c}$., oz. roc., 1b. $65 \mathrm{c}$. Mailing, $8 \mathrm{c}$. ib. PHINNEY'S EARLY.-A very early medium-sized sort; flesh red, excellent quality, hardy, very prolific. Pkt. 5c., oz. 1oc., 1b. $65 \mathrm{c}$.

Mailing, 8c. 1b. PRESERVING MELON.-Quite distinct from the Citron; immensely productive. Flesh very firm and solid, with few seeds. Preserving qualities are the very finest. It makes beautiful, clear, nearly transparent preserves of surpassing flavor. Pkt. 5c, oz. roc., 1b. 80 c. Mailing, 8c. $1 \mathrm{~b}$.

VECETARI MANGO MELON OR VINE PEACH.-Round, Prot light yellow fruits, good for making preserves

PEACH. enormously productive; flavor excellent. Although an acquisition, and has become very popular. Pkt. Ioc., oz. $35 \mathrm{c}$., $1 \mathrm{~b}$. $\$ 4.00$. Mailing, 8c. $1 \mathrm{~b}$. 


\section{MUSHROOMS FOR THE MILLION.}

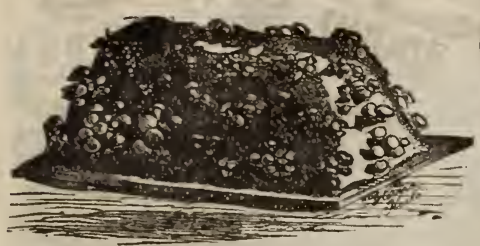

MOTABLE MTSHROOM SHELF.
Gardiner's Genaine Milltrack Mashroom Spawn.

Although the Mushroom is one of the most delicious, and, at the
same time, most nutritious of all known esculents, its cultivation is not generally understood, and its use is much more limited than it onght to be. There are in a fair way to be removed, now

that commercial gardeners, as well as private families, are turning their attention to its culture, and we think that in the near future the mushroom is ciestined to take its true place as one of the most important and delicious of esculents, which no well-appointed household can afford to do without. We have prepared and published an \&-page pamphlet, written by a practical grower, which gives in a concise form all $\mathrm{nec}$ essary information for the successful raising of the best mushrooms. This pamphlet will be sent free to any one interested. We make a specialty of supplying the genuine English Milltrack Mushroom Spawn. It is specially prepared for our trade by one of the best mushrooni growers in Worcestershire. We receive four importations a year, so that customers can depend on receiving the spamn fresh and genuine at all times. $\mathrm{Br}$ mail, postpaid, 22c. per $1 b$.; 5 lbs. for $\$ 1.00$. By express, at customers' expense, Io lbs. for $\$ 1.20 ; 251 \mathrm{bs}$, for $\$ 2.73: 501 \mathrm{bs}$. for $\$ 5.00$. Special prices on large lots. FRENCH MUSHROOM SPAWN. More bulky than the English, being packed loosely in 2-1b. boxes. By express, $80 c$. per box (2 lbs.) ; 10 boxes $\$ 7.00$. By mail (in paper), \&c. per $1 \mathrm{~b}$. extra.

Mushroom Culture.

By W.r. RoBIssox, F.L.S. Author of

"The Parks and Gardens of 'Paris.' New edition. 172 pages. Cloth. 50 cents, post-paid.

Chapters on "Mushroom House," "Preparation of Materials," ". Spawn," "Spawning," "Culture in Cellars and Outhouses," "Cave Culture," "Culture in the Open Air," "Culture in "Modes of Cooking," etc. Profusely illustrated.

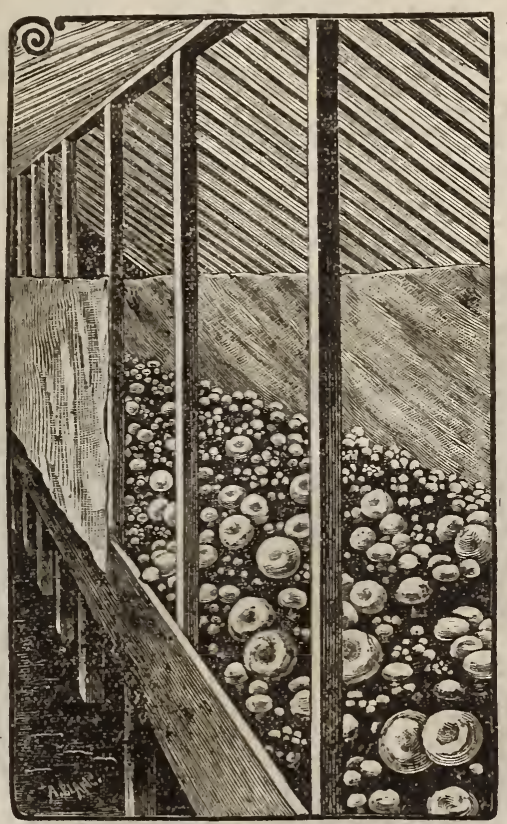

Meshroous IN GREEN-HoUse.

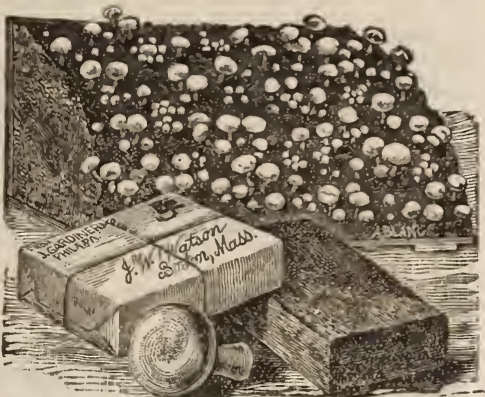

GARDINER'S GENUINE ENGLISH MILLTRACK MIUSHROOM SPAWN.

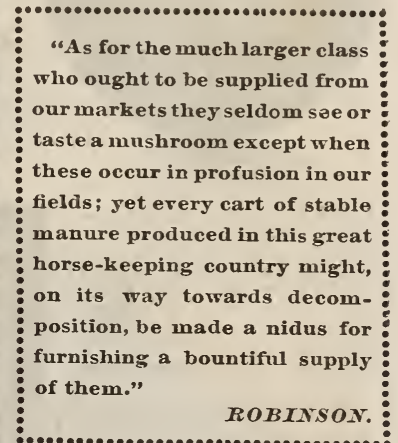

We append below a few extracts from letters received from mushroom growers, in regard to the quality of our spawn.

50 to 70 lbs. Fine Mushrooms per Day

"I must say that the spawn we got from you did very well. We shipped from it 50,60 and $701 \mathrm{bs}$. per day of very fine mushrooms."

$$
\text { JAMES Y. GIBSON. }
$$

Mushrooms 7 in. Diameter.

The mushrooms I had from you one year ago did remarkably wellmany of them were over 7 inches in diameter, as large as a tea saucer." WOODBRIDGE STRONG.

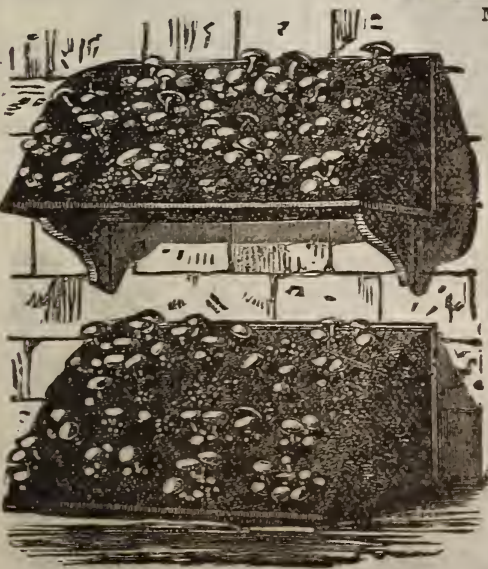

MUSHROOMS ON SHELVES.
Very Satisfactory.

"The mushroom spawn you sent, turned out to my entire satisfaction. Will want some more very soon." CARL. BEERs. Better Than Any Other.

"Your spawn fills the bill better than any I have bought elsewhere." JOHN G. GARDNER.

These are samples of hundreds of others, all from large and successful mushroom growers. One customer, Mr. H. A. Lea, who had been trying for three years previous to last July to get mushrooms, tried some of our spawn, and had $\mathrm{such}$ a splendid crop of fine mushrooms, that he is now going into their culture enpeople only knew how easy mush. rooms are to grow, they would certainly plant, so as to have a good supply all the year round ing on the short summer supplies from our fields.

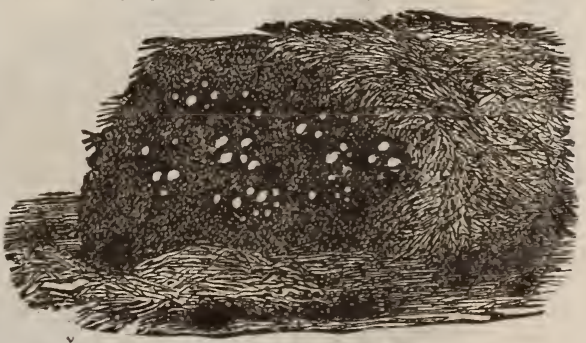

MTSBROOM BED (RIDGE), ONE SIDE UNCOVERED. 


\section{SELECTED ONION SEED.}

Next to the cabbage the onion is our most important vegetable, and the importance of having good seed cannot be over-estimated. It requires the greatest care in selecting only the best shaped bulbs for seed purposes in order to keep the strain up to a thoroughbred standard. Carelessness in selecting will inevitably result in a splendid crop of "scallions." Our seeds are saved from the best selected bulbs, grown and harvested with the

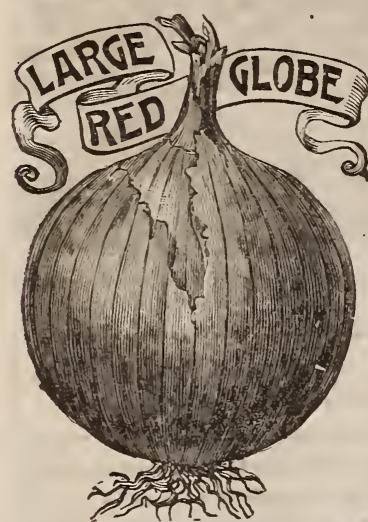

LARGE RED GLOBE.Large, medium early, skin deep red, small neck, flesh fine grained, mild flavor, productive, a good keeper, and an excellent PLt. 5c., oz., I5c. 1b. \$I.45. Mailing, $8 \mathrm{c} .1 \mathrm{~b}$.

We can offer special in-
ducements to truckers
and other large growers
who buy in large quanti-
ties. Lowest raies for

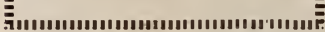
LARGE RED WETHERS. FIELD.-The most popular red onion for general crop, latge, fine form, skin deep red, flesh white, strong flavor, immense cropper, and keeps well. Pkt. 5c., oz. Ioc., lb. \$I.15. Mailing, White Globe-Larger and later than the White Silverskin, and also more globe shaped. Pkt. 5c., oz, 20c., 1b. \$1.90. Mailing, $8 \mathrm{c} .1 \mathrm{~b}$. most scrupulous care, and, we do not hesitate to say, cannot be surpassed in quality. Our prices will be found as reasonable as is consistent with the great care and expense consequent to our method of selecting and saving our seeds.

d) Full sized onions the first year from seed may be obtained by sowing our thoroughbred seeds in the South, as well as in the Eastern and Western States. For full sized onions, the first year sow 4 or 5 lbs. of seed. For small sets, 40 best sorts for sets are: Yellow Danvers, Yellow Strasburg, Extra Early Red, White Silversizin,

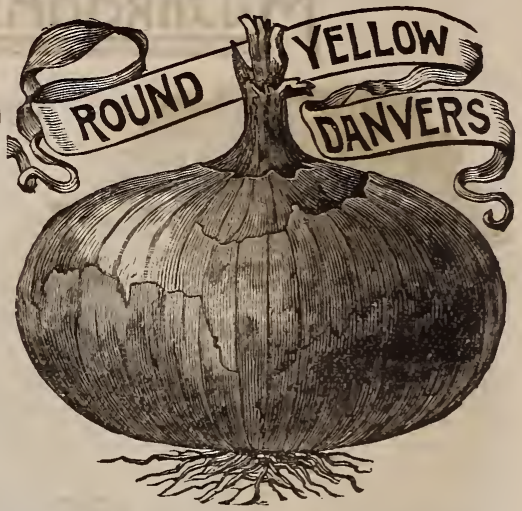
ROUND YELLOW D ANVERS. - A popular,profitable and excellent sort, round, yellow. not so globe shaped as tle Globe Danvers, largely used for raising small sets, and a splendid all round onion; mild flavor, very productive, and keeps well. Pkt.5c.,oz. 10c.,1b.8oc. Mailing, 8c. ib. YELLOW GLOBE DANVERS. - This is conceded to be the finest strain of Danvers in cultivation. It is grown in New England, and is exceedingly pure and true to type; early, round, very small neck, fine grained, mild flavor, immensely productive, and unsurpassed in keeping quality. Pkt. 5c., oz. 10c., 1b. \$I.I5. Mailing, 8c. 1b.

EXTRA EARLY RED.-A very early variety of medium size, round, flat, deep red, d flavor, largely grown for sets. Pkt. 5c., oz. I5c., 1b. \$1.40. Mailing, 8c. 1b.

WHITE SILVERSKIN. (Syn: Philadelphia Silverskin, Large White Portugal.)-

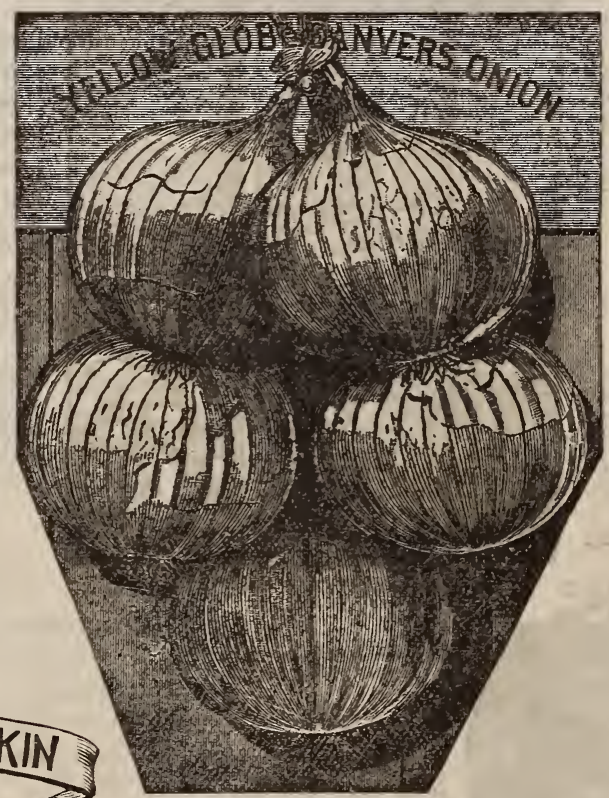
Early, medium size, silvery white, mild flavor, excellent for home use or market. Largely grown for producing the white onion sets. When young used for pickling. Pkt. 5c., Oz. 20c., 1b. \$1 go. Miailing, 8c. lb. Globe shaped, large, handsome, good favor, excellent keeper not quite so early as the Globe Danvers, but very productive. Pkt. 5c., oz. I5c., 1b. \$1.40. Mailing, sc. $1 \mathrm{~b}$.
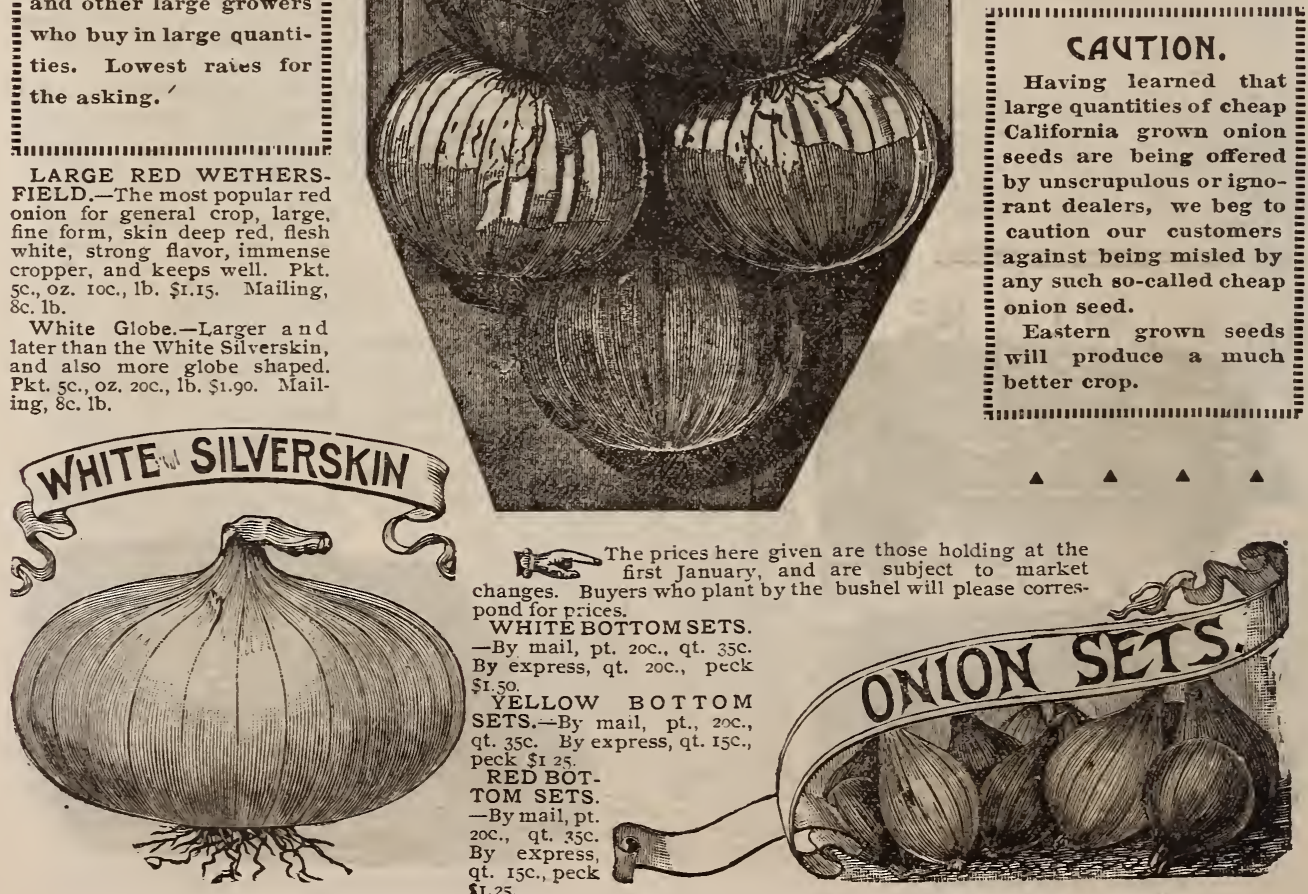

The prices here given are those holding at the first January, and are subject to market pond for prices.

WHITE BOTTOM SETS.

- By mail, pt. 20c., qt. 35c. \$I.50. YELLOW BOTTOM SETS.-By" mail, pt., $20 \mathrm{c}$. qt. 35c. By express, qt. $15 \mathrm{c}$. peck \$I 25. TOM SETS -By mail, pt. 20c., qt. $35 \mathrm{c}$. qt. r5c., peck \$1. 25 .

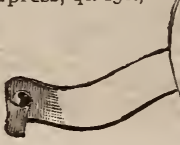




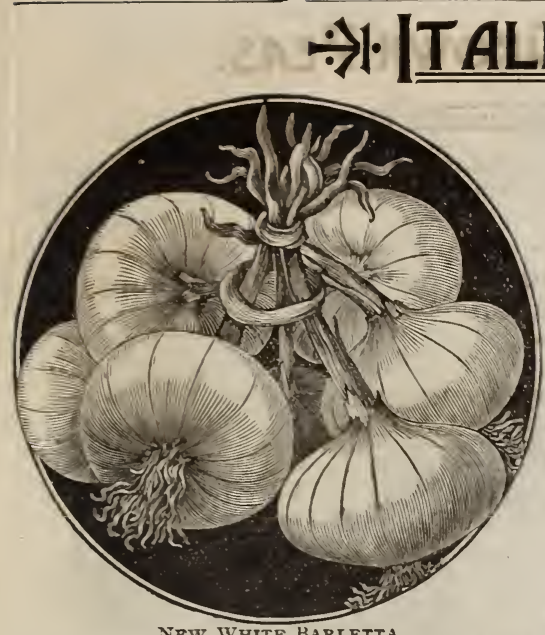

\section{ONIONS}

These are getting more popular every year, on account of their quick growth, mild flavor, and generally large size, some varieties weighing from two to three pounds the first season from seed, and even the suallest if saved and set out the following spring, will grow onions weighing from three to four pounds. They succeed well in all parts of the couutry, and are grown very extensively in the South, and are shipped Nortl 1 as Spanish and Bermuda onions. The sinall sorts, such as Queen and Barletta, are most valuable, on account of their extreme earliness and nild flavor.

Note.-Our seeds of Italian onions are imported by us direct fi $\cdot$ rr italy, and can be relied on as second to none, and much superior to that generally procured through the regular jobbing houses.

WHITE QUEEN.-Small, very early, white-skinned, mild flavor, excellent for pickling. Pkt. 5c., 0z. 20c., 1b. Si.75. Mailing, 8c. 1b.

WHITE BARLETTA.-Similar to White Queen, but 30 days earlier. Pkt. 5c., Oz. 20c., 1b. \$r.75. Mailing, 8c. 1b.

GIANT BROWN ROCCA.-A large globe shaped variety, mild flavored, skin light brown, handsome, excellent. Pkt. 5c., oz. 20c., lb. \$r.75.

GIANT BLOOD RED ROCCA.-Red-skinned, beautiful globe shaped similar to the Yellow and Brown Rocca, except in color. Pkt. 5c., oz, 20C. b. $\varsigma_{1}, 75$. Mailing, 8c, 1 b.

GIANT YELLOW ROCCA.-Handsome golden yellow, similar to preceding except in color. Pkt, 5c, oz, 20c, 1b. 51.75. Niailing, \&c. $1 \mathrm{~b}$.

MAMMOTH SILVER KING.-One of the largest onions in cultivation early; shape flat, but very thick; skin a silvery white; flesh mild, delicate, and of snowy whiteness; a handsome and very popular variety. Pkt. $5 \mathrm{c}$., OZ. $20 \mathrm{M}$ MMOTH $\$$ RED POMPEII.-Similar to the Silver King exceptin

NEW WHITE BARLETTA. color; an excellent companion to that magnificent variety. Pkt. 5c., oz, 20c., 1b. \$r.75. Mailing, $8 \mathrm{c}$. 1b.

RED BASSANO, OR GENOA.-Large, deep red, mild flavored, good keeper, very productive. Pkt. 5c., oz. 20c., 1b. \$r.75.

Mailing. 8c. lb. Plst. 5c., Oz, 20c.. 1b. \$I.75. Mailing, 8c. 1b.

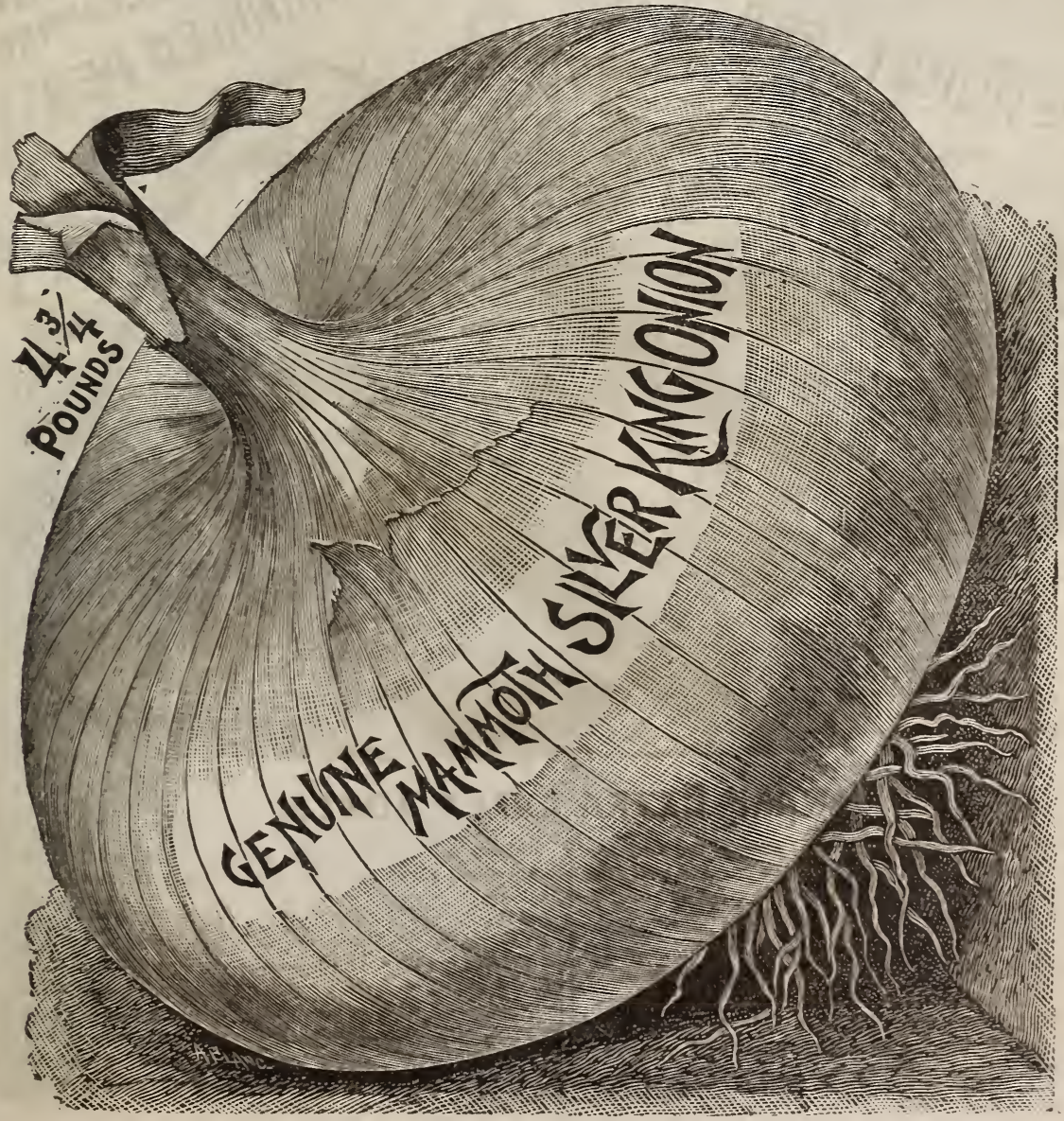




\section{Selected Northern Grown Peas.}

\section{$\therefore \mathrm{O}_{0}^{\circ}$}

Ourseed peas are all grown in Northern New York, the finest pea-growing district in the world, and are carefully selected from the choicest stocks, inspected and rogued with scrupulous care during growth, and carefully hand-picked after harvesting. For purity of type and perfection in quality, our stock cannot be surpassed.

7 Truckers and other large growers who use peas in quantity supplied at trade prices. Special rates on application.

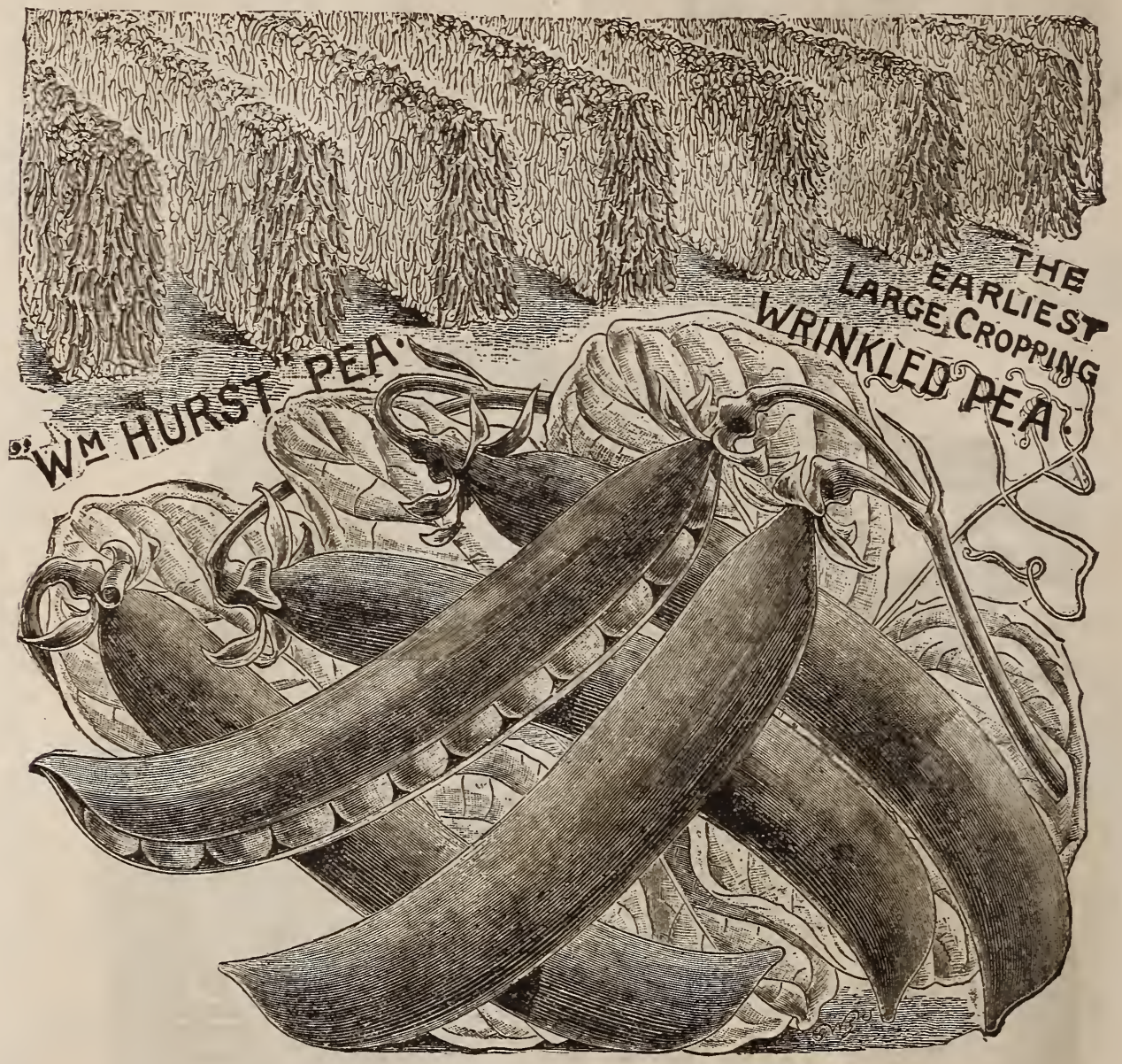

\section{DWARF EXTRA EARLY SORTS.}

BLUE BEAUTY.-A blue round pea as early as the American Wonder, grows very uniform, pods medium size and well filled for an extra early; very productive and or unsurpassed quality. Height $13 / 4 \mathrm{ft}$. Pkt. Ioc., qt. $3 \circ \mathrm{c}$. Mailing, I5c. qt.

TOM THUMB.-Remarkably dwarf and early; an abundant yielder and fine quality. Height $\mathrm{I} f \mathrm{ft}$. Pkt. Ioc., qt. 25c. Mailing, I5c. qt.

EXTRA EARLY PREMIUM GEM.-An improved Little Gem; dwarf, prolific, fine flavored, large pods; excellent either for market or home use. Height $I^{1} / 4 \mathrm{ft}$. Pkt. 1oc., qt. 25c. Mrailing, s5c. qt.
McLean's Little Gem.-An early green marrow, of excellent quality, and an abundant bearer. Height $I^{1} / 2$ ft. Plt. Ioc., qt. 25C. Mailing, $15 \mathrm{C}$. qt.

WM. HURST.-This magnificent new dwarf, extra early, has fully borne out the high praise given it, and has become exceedingly popular. It is a little taller than American Wonder, but quite as early; a better yielder and has larger pods; a splendid cropper, with large, curved, handsome pods, which are much larger than the Wonders. The peas are blue, wrinkled and of delicious quality, sweet and juicy. A distinct and valuable introduction. Pkt. Iec., 3 pkts. 25c. 


\section{SELECTED NORTHERN-GROWN PEAS.}

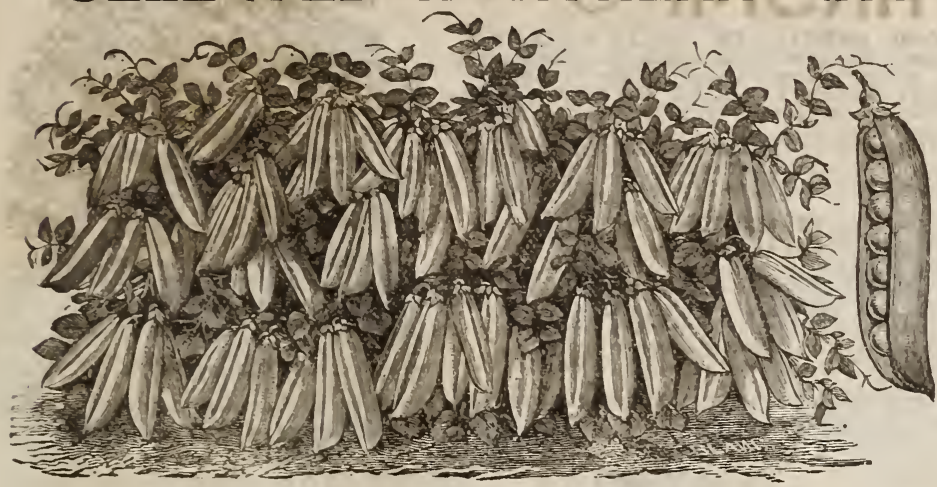

OWARF FNTRA

EARLI.

AMERICAN WONDER.-The dwarfest pea grown, extremely early, fine quality; splendid for home use. Not productive enough for a profitable market pea; but largely used on account of it $3 / 4 \mathrm{ft}$. Pkt. Ioc., qt. 25c. Mailing. 5c. qt. EXTR

EARLY SORTS. (Medium Height.) EXTRA EARLY PHILADEL PHIA. (Gardiner's Choice Stock.) - An extra early strain of this markable for its uniform growth great productiveness, and delicious quality. Wecan recommend this as the most profitable sort

\section{AMERICAN WONDER.}

for truckers and large growers: our choice stock is selected with the greatest care and is a great improvement on the tv pe. Height, $2 \frac{13}{2} \mathrm{ft}$. Pkt. 10c., qt. 25c. Mailing, $15 \mathrm{c}$. qt. IMPROVED DANIEL O'ROURKE.-Very early, fine cropper, long pods, exquisite flavor: can be gathered at one picking-a most important point for the market grower. Our stock is extra select. Height, $2 \frac{1 / 2}{2} \mathrm{ft}$. Plt. Ioc., qt. $25 \mathrm{C}$. Mail-

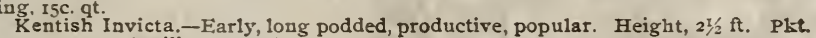

Ioc., qt. 25c. Mailing, 15c. qt. ft. Pkt. Ioc., qt. 25c. Mailing, I5c. ot.

Laxton's Alpha.-An early, wrinkled, marrow; of good quality. Height, $2 \mathrm{ft}$. PLt. Ioc., qt. 25c. Mailing, I5c. qt.

\section{DWARF SECOND EARLY SORTS.}

Horsford's Market Garden.-A splendid new pea : very productive, and of the finest quality, unexcelled for market. Height, $2 \mathrm{ft}$. PLt. 1oc., qt. 25c. Mailing, r5c. qt. Bliss' Abundance.- Terr' productive and fine flavored. A bushy growing variety - sow thinly. Height, 2 ft. Pkt. roc., at. 25c. Mrailing, 15c. qt

SECOND EARLY SORTS. (Medium Height.)

MCLEAN'S ADVANCER.-A fine flavored, green, wrinkled marrow ; very productive and uniform; the leading second early for market or home use ; a great favorite with truckers, and highly recommended. Height, 21/2 ft. Pkt. Ioc., qt. $25 \mathrm{C}$. Mailing. I5C. qt.

FILLBASKET.-One of the finest second earlies, very heary cropper, seeds greenish blue, exquisite flavor. Height, $2 \frac{1 / 2}{\mathrm{ft}}$. Pkt. 10c., qt. 25c. Mailing, $15 \mathrm{c}$. qt. DIVARF MLAI CROP SORTS.

STRATAGEM - One of the best late marrows in cultivation: immense, large pods, splendid flavor, rigorous dwarf growth, very popular. Height, $2 \mathrm{ft}$. Plkt.

Bliss' Everbearing. - A large podded, prolific, finely flavored sort; continues a long time in bearing. Height, $2 \mathrm{ft}$. Pkt. Ioc., qt. 15c. Mailing, $15 \mathrm{c}$. qt. Pride of the Market. Dwarf. loc., qt. $30 \mathrm{c}$. Mrailing, 15c. qt.
handsome. Height, $2 \mathrm{ft}$. Pkt. Ioc.
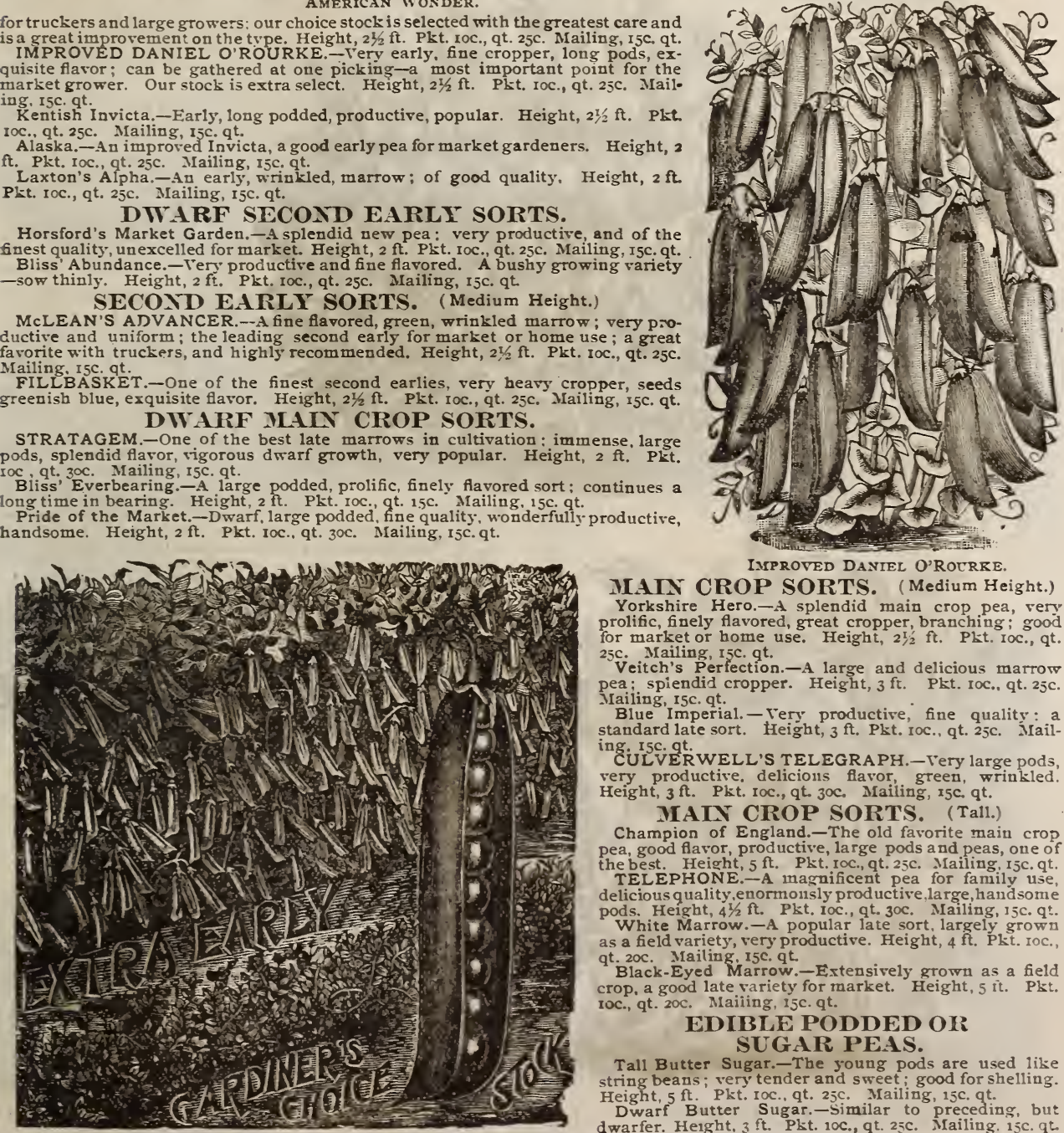

IMPROVED DANIEL O'ROIRKE.

MANT CROP SORTS. (Medium Height.)

Yorkshire Hero.-A splendid main crop pea, ver prolific, finely flavored, great cropper, branching; good for market or home use. Height, 2 $\frac{1}{2}$ ft. Plt. roc., qt. 25c. Mailing, I5C, qt.

Veitch's Perfection.-A large and delicious marrow pea; spiendid cropper. Height, 3 ft. Plt. Ioc., qt. $25 \mathrm{C}$ Iailing, r5c. qt.

Blue Imperial. - Very productive, fine quality . standard late sort. Height, $3 \mathrm{ft}$. Pkt. Ioc., qt. $25 \mathrm{c}$. Mrailing. ISc. qt. very productive, delicions flavor, green, wrinkled. Height, 3 ft. Pkt. Ioc., qt. $30 \mathrm{c}$. Mailing, x5c. qt. MAIT CROP SORTS. (Tall.)

Champion of England. The old favorite main crop pea, good flavor, productive, la rge pods and peas, one of the best. Height, $5 \mathrm{ft}$. Pkt. Ioc., qt. 25c. Mailing, 15c. qt. TELEPHONE.-A magnificent pea for family use, delicious quality, enormonsly productive, la rge, handsome pods. Height, $4 \frac{1}{2} \mathrm{ft}$. Pkt. Ioc., qt. 30c. Mailing, 15c. qt. as a field variety, very productive. Height, $4 \mathrm{ft}$. Pkt. Ioc. qt. 20c. Mailing, 15c. qt.

qlack-Eyed Marrow.-Extensively grown as a field crop, a good late variety for market. Height, $5 \mathrm{ft}$. Plt. Ioc., qt. 20c. Maiiing, $15 \mathrm{c}$. qt.

\section{EDIBLE PODDED OR} SUGAR PEAS.

Tall Butter Sugar.-The young pods are used like string beans; very tender and sweet; good for shelling. Height, $5 \mathrm{ft}$. Pkt. IOc., qt. 25c. Mailing, $15 \mathrm{c}$, qt. Dwarf Butter Sugar.-Similar to preceding, but dwarfer. Height, 3 ft. Plt. 10c., qt. 25c. Mailing. 15c. qt. 


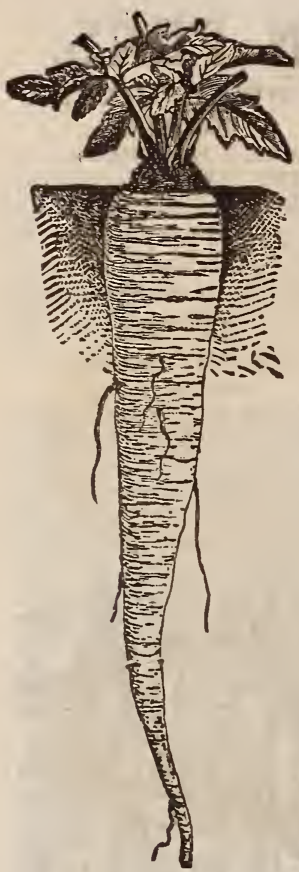

IMPROVED GUERNSEY. CELESTIAL PEPPER.This is not only one of the most useful varieties for culinary uses, but also one of the
most handsome and attractive. It is of compact habit, growing about $2 \frac{1}{2}$ feet in fruits well above the foliage, as shown in the engraving. Each pepper is beautifully variegated with bright golden and deep red, sometimes striped or variegated; immensely productive. Quite hardy, and easily grown. Pkt. IOC., Oz. 5OC.

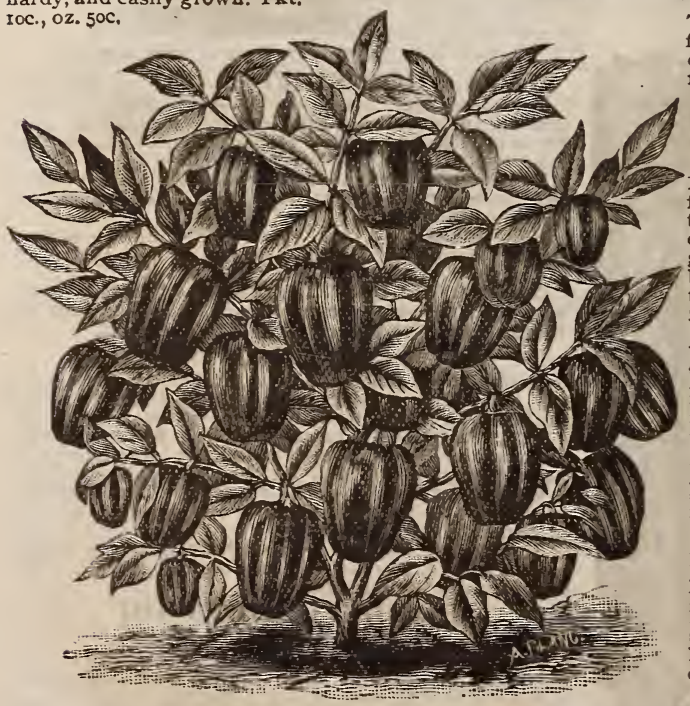

RUBY KING PEPPER.

\section{가PARSLEY} Pkt. 5c. Oz. IOc.. 1b. 9oc. Mailing, 8c. $1 \mathrm{~b}$. ing, $8 \mathrm{c} .1 \mathrm{~b}$. Pkt. 5c., OZ. IOC., $1 \mathrm{~b}$.

\section{PARSNIPO}

LONG SMOOTH, OR HOLLOW CROWN. (Abbot's Improved.)-The standard sort for general

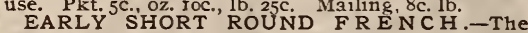
earliest: good quality. Pkt. 5c., oż. Ioc., 1b. 5oc. IMPROV 1 ED GUERNSEY._-Smooth, fine grained, excellent; shorter than the Hollow Crown; a heavy cropper. Pkt. 5c., oz. 1oc., 1b. 50c. Mailing, 8c. 1b.

FERN LEAVED.- Tery fine form, extra selected. BEAUTY OF THE PARTERRE.-The hand-

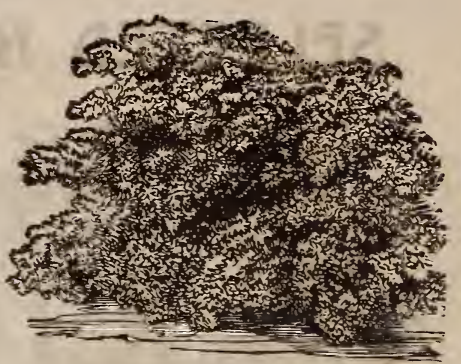

Moss Curled Parsley. somest curly parsley in cultivation; very distinct; makes beautiful edging for flower-beds, and MOSS CURLED.-Exquisitely curled, and of the richest green. Plat.5c., oz. Ioc., 1b. 65c. MailHAMBURG OR ROOTED PARSLEY.-The roots of this sort are used for flavoring soups and.

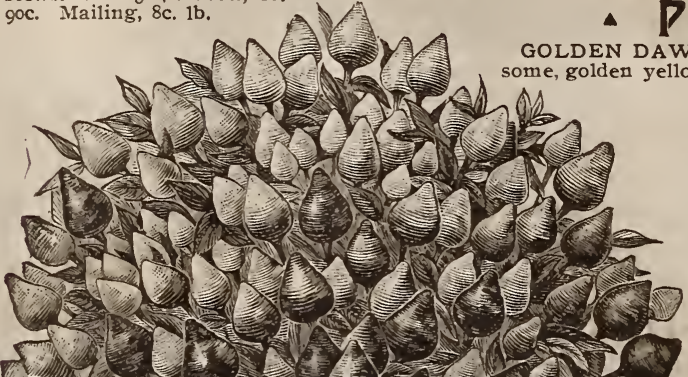

PEPPER. 4

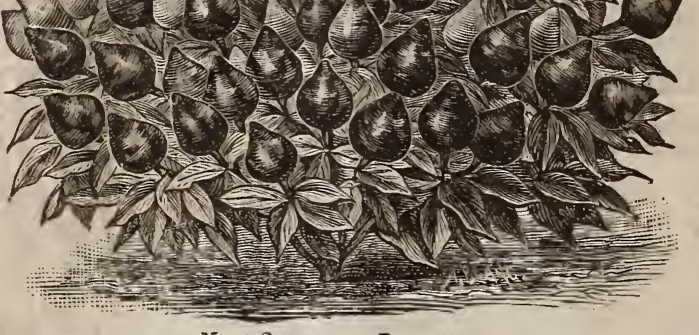

N.-A new variety, very hand. ductive. Pkt. 5c., oz. $30 \mathrm{c} ., 1 \mathrm{~b}$. $\$ 2.75$. Mailing, 8c. 1b.

RED CHILI.-Small, cone. shaped, bright red, fiery. Pkt. 5c., Oz. 25c., 1b. \$2.25. Mailing, LARGE BELL, OR BULL. NOSE red, mild. Pkt. 5c., oz, 25c.,1b. $\$ 2.25$. Mailing, 8c. 1b

SWEET MOUNTAIN.A large, early sort, mild and excellent, bright red. Pkt. 5c., oz. 25c.,1b. \$2.25. Mailing.8c. Ib. CAYENNE LONG RED.Long, bright red, fiery. Pkt 5c., Oz, 25c., 1b. $\$ 2,25$. Mailing. 8c. lb. round, glossy red, very fiery, Plt. 5c., oz. 25c., 1b. $\$ 2.50$. Mailing, $8 \mathrm{c}$. 1b. RIGHT.-New and distinct grows twice as large as the Golden Dawn, fine for man goes. Pkt. IOC., Oz. $50 \mathrm{c}$.

RUBY KING.-The Ruby King is an enormous bearer, each stalk having from Io to 14 large peppers. Many of the fruits measure 7 ins. in length, and 4 to 5 ins. in diameter. They are of a beautiful ruby red, thick meated, and mild in flavor. Their flavor is so pleasant that they can be sliced and like tomatoes or cucumbers. The best pepper for mangoes in cultivation. Pkt. roc., oz. $35 \mathrm{c}$.

\section{PUMPKIN.} JAPANESE PIE.Remarkable $\nabla$ ariety from Japan. Flesh very dry and sweet; early; good keeper, and fine bearer. A great acquisition. Pkt. 5C., oz. Icc.,1b. \$I.25. Mailing, 8c. $1 \mathrm{~b}$. Very superior, produc tive, fine grained, good tive, flavor, cheese shaped. Pkt. 5c., oz. 10c., 1b. $75 \mathrm{C}$. Mailing, 8c. 1b.

CASHAW.-One of the largest and best yellow, solid, good keeper. Pkt. 5c., oz. 10C 1b. 75c. Mailing, 8c. 1b. IMPROVED MAMMOTH OR POTIRON -Grows enormously large, from round, flattened : skin salmon; flesh yel-

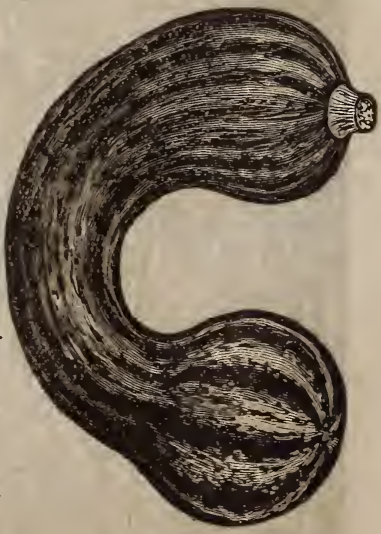

Japanese Pie PUMPKIN. low, fine grained, good $15 \mathrm{c}, 1 \mathrm{~b} . \$ 1.75$. Mailing, 8c. 1b. quality. Pkt. 5c., oz. I5c., 1 b. $\$ 1.75$. Mailing, $8 \mathrm{c} .1 \mathrm{~b}$. Pkt. 5c., 0z. roc., 1b. 25c. Mailing, 8c. 1b. 


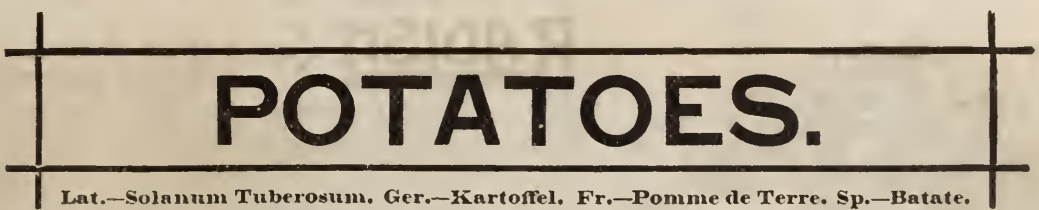

Our seed potatoes are all Forthern grown, from specially-selected tubers, and are guaranteed to be as pure stock as any
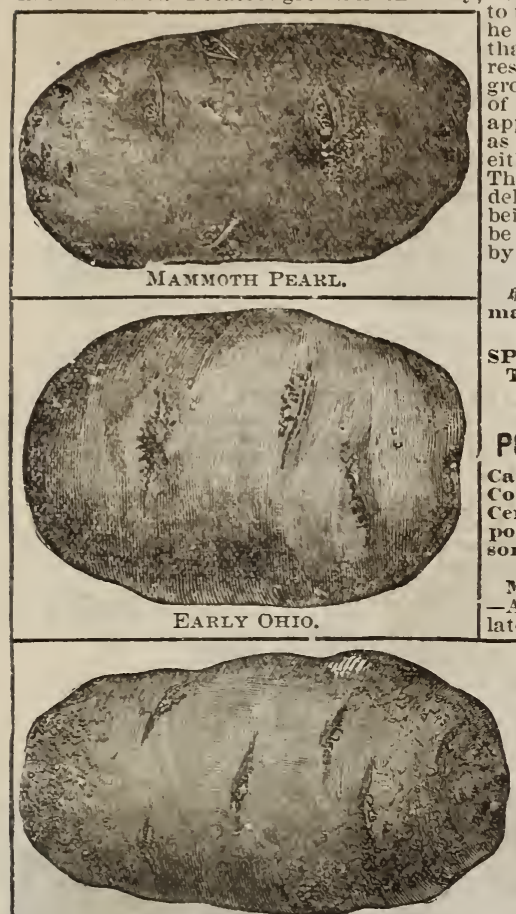

DAKOTA RED.
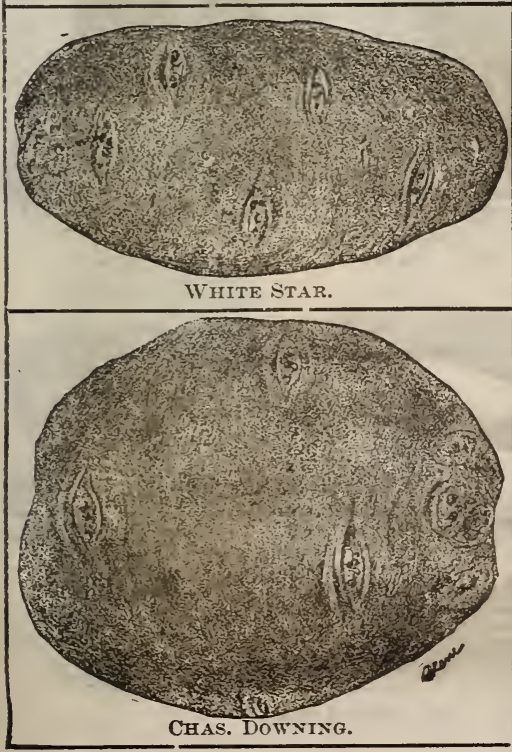
to the farmer to be sure when, that he gets only the best. The
results in increased vigor of growth, yield and earliness of maturity will be speedily apparent. We ship as soon as danger from frost is past, either by freight or express. delphia with seaports in south being unequaled, it will often be found economical to send by sea.

앙 Prices are subject to market changes.

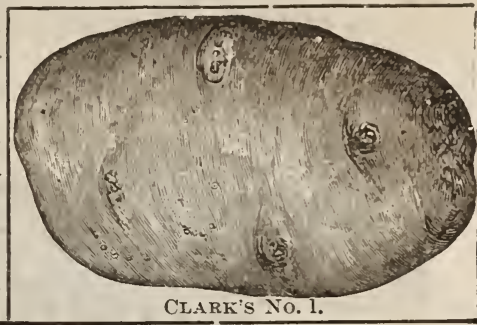

SPECIAL PRICES ON TEN-BARREL LOTS OR OVER.

POTATOES BY MAIL, Carefully Packed and Correctly Labeled, 30 Cents per pounc. Five porunds for $\$ 1.00$ for all sorts enumerated below.

MAMTOTH PEARL. late variety, of excellent quality and very productive; keeps well. $\$ 2.00$, barrel $\$ 1.00$.

CLARK'S No. I.Early and more productive than Early Rose, which it somewhat resembles. Peck 75 cents, bushel, $\$ 2.25$. barrel \$4.50.

EARLY OHIO - Very early. Peck 75 cents, bushel $\$ 2.25$, barrel $\$ 4.50$,

EIIPIRE STATE. - Very productive good quality. Peck 75 cents, bushel $\$ 2.25$, bar
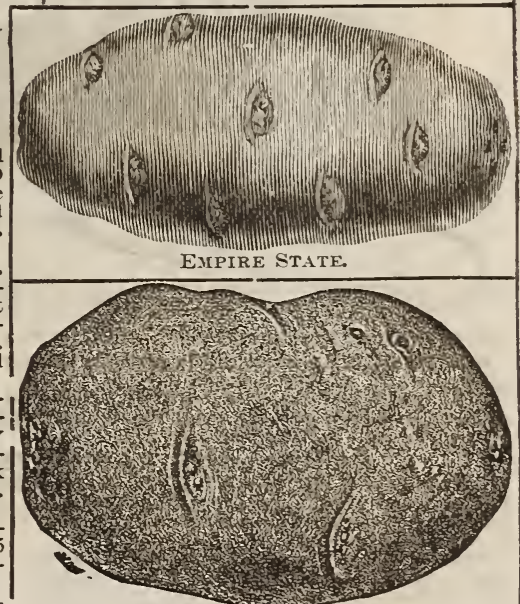
rel $\$ 4.50$.

BEAUTY OF HEBIRON.-The most popular early variety grown; skin rose colored; flesh pure white, fine quality. Peck 75 cents, bushel $\$ 2.25$, bar rel $\$ 4.50$.

DATA RED.A late sort; red skin, White flesh, productive, profitable. Peck barrel \&4.50.

WHITE STAR.Medium early, fine quality, productive, cents, bushel $\$ 2.00$, barrel $\$ 4.00$.

EARLY ROSE. -The standard early sort. Peck 65 cents, bushel $\$ 2.00$ barrel $\$ 4.00$.

CIIAS. DOWNING.- - Very handsome; fine quality. $\$ 3.25$, barrel $\$ 7.00$. S T A T E O F MA I $\mathbf{N}$ E. - A me dium early; ver mealy, whité flesh. Peck 75 cts., bushe $\$ 2.25$, barrel \$4.50.

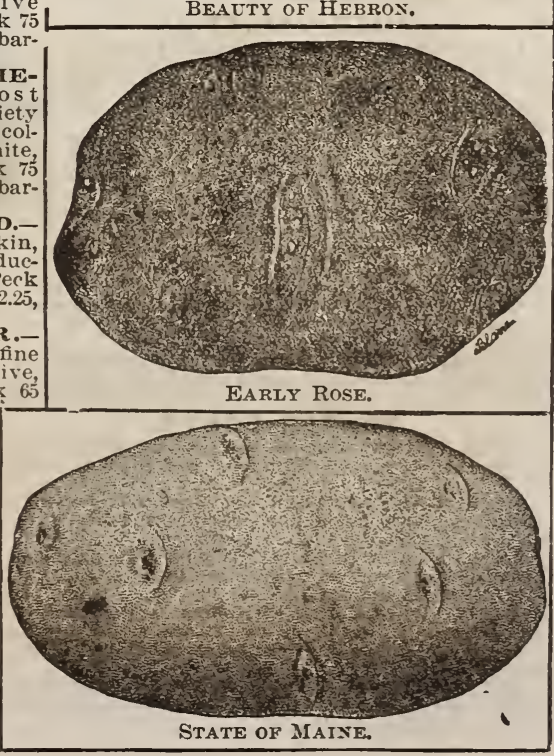




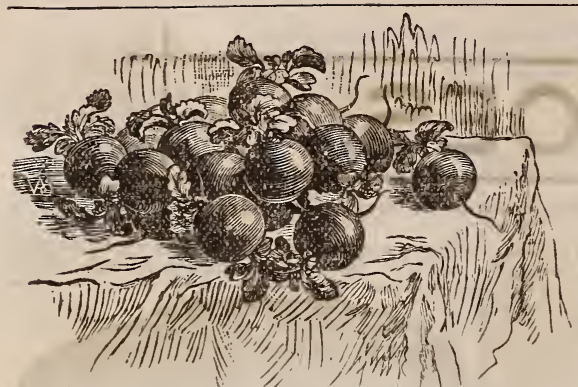

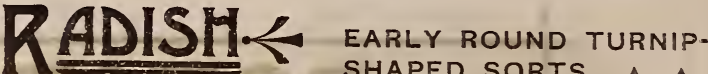 \\ SHAPED SORTS. A}

The early round radishes are well adapted for forcing on account of their earliness. The tops are small, making them excelleut for growing under glass; and their fine shape and color is particularly noticeable and attractive. For market purposes they are unsurpassed Our seed is very carefully selected, being saved from transplanted stock

EARLY ROUND DEEP SCARLET FORCING.-A distinct new type, of perfect form ; round and smooth, fine deep scarlet color and short top, flesh white, crisp and pleasant, very quick grower. Pkt. 5c. oz. 1oc., 1b. Sr.0o. Mailing, 8c. 1b.

EARLY ROUND SCARLET WHITE-TIPPED FORCING.-NIOS1 attractive variety; beautiful scarlet, tipped with white. smooth and eve: in form; very quick grower and excellent flavor. Pkt. 5c., oz. IOc., 1b. EARLY ROUND WHITE FORCING.-One of the earliest and for forcing ; round, smooth, pure white, small top and tap root; crisp and mild in flavor. Pkt. 5c., Oz. Ioc., 1b. \$I.Oo. MTailing, 8c. 1b.

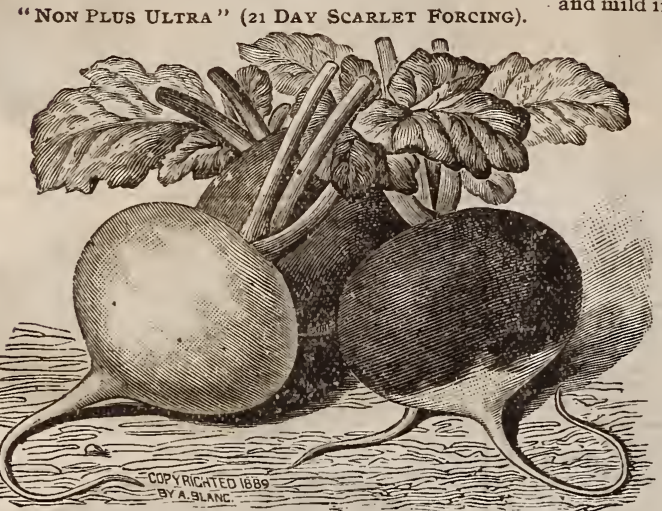
NON PLUS ULTRA SCARLET FOR CING-This splendid new radish is of fine round form; bright scarlet, short top, fine flavor, of remarkably quick growth and one of the very best of the new forcing radishes. Fit for use in $2 \mathrm{r}$ days. Pkt. $5 \mathrm{C}$., oz. $10 \mathrm{c}, 1 \mathrm{~b}$. $\$ 1.00$. Mailing, $8 \mathrm{c}$. $1 \mathrm{~b}$.

SCARLET TURNIP.-Very early, round, rich scarlet, small top, one of the best ; fine for forcing. Pkt. 5c., oz. 10c. $1 \mathrm{~b}$. 45c. Mailing, 8c. $1 \mathrm{~b}$.

WHITE TURNIP.-Same as the preceding, but white. Pkt. 5c., oz. 10c., 1b. 45c. Mailing, Bc. 1b.

WHITE-TIPDED SCARLET TURNIP.-A small round variety, very attractive, excellent. Plt. $5 \mathrm{c}$, oz. 10c., 1b. $45 \mathrm{C}$. Mailing, 8c., 1b.

PHILADELPHIA WHITE BOX. (Felton's.)-Remarkably short top, rapid grower, fine quality, perfect turnip shape, sweet and juicy, long standing, good for forcing, a favorite with Philadelphia market gardeuers. Pkt. 5c., oz. I5c., 1b. \$1.00. Mailing, oc. 1b.

\section{EARLY OLIVE-SHAPED SORTS.}

RED ROCKET.-Olive-shaped, brilliant scarlet, one of the earliest and showiest radishes in cultivation, short top. fine quality and excellent for forcing. Pkt. 5c., oz. 15c., lb. $\$ 1.00$. Mailing, 8c. 1b.

FRENCH BREAKFAST.-An oval sort, scarlet, with white tip, crisp tender. Pkt. 5c.,0z. I5c.1b. 5oc. Mailing, 8c. 1b. SCARLET OLIVE.-Oblong, scarlet, tender, good forcer

White TURNIP. SCarlet TURNip. Scarlet TURNip, White Tip. Pkt. 5c., oz. 10c., lb. 5oc. Mailing, 8c. lb.

WHITE OLIVE.-Same as the preceding, except in color. Pl. 5c., OZ. IOc., 1b., 5oc. Mailing, 8c, $1 \mathrm{~b}$. in all other respects to the other olive-shaped varieties. Pkt. ${ }^{\mathrm{C}}$., oz. 10c., 1b. 9oc. Mailing, $8 \mathrm{c}$. 1b.

\section{EARLY LONG VARIETIES.}

LONG SCARLET SHORT TOP. (Salmon Short Top.)-Rich scarlet, long shape, short top, straight, smooth, early, crisp, tender, very popular both for market and home use. Pkt. 5c., oz. Ioc. der, very popular both for

1b. 6oc. Mailing, 8c. 1 b. Scarlet, but Io days earlier and not quite so long, an excellent forcing variety. Pkt. 5c., oz. Ioc., 1b. 5oc. Mailing, 8c, 1b.

\section{SUMMER VARIETIES.}

LONG WHITE VIENNA. (Lady Finger.)Considered the finest long white radish in cultivation, perfect in. shape and snowy white, crisp, juicy and of fine rapid growth. Pkt. 5c., oz. Ioc.

1b. 5oc. Mailing, 8c. 1b. pure white sort, firm, crisp, juicy, does not get pithy, a quick grower and can be used at any stage of growth. Pkt. 5c., oz. Ioc., 1b. 5oc. Mailing, 8c.1b. ing summer sort, recommended for its long standing qualities. Pkt.5c., oz.10c.,1b. 9oc. Mailing, 8c.1b. Summer Turnip White.-One of the best for mer use, Pkt. 5c. Oz. 10c., 1b. 65c. Mailing, 8c. 1b.

WHITE STRASBURG.-A large, handsome, white variety, of excellent quality, early. Pkt. 5c., oz. roc., 1b. $65 \mathrm{c}$. Mailing, 8c. $1 \mathrm{~b}$

BECKERT'SCHARTIER.-Grows to a large sizewithout losing its tenderness; scarlet, tipped with white, long crisp and tender. Pkt. 5c., oz. 10c., 1b. 65c. Mailing, 8c. 1b.

\section{WINTER SORTS}

ROSE CHINA - One of the best for winter use, bright rose color, flesh firm, crisp and piquant. Pkt. 5c., oz. 1oc., 1b. 65 c. Mailing, 8c. 1b.

LONG GRAY WINTER.-Somewhat larger than Black Spanish, splendid keeper and fine quality. Pkt. 5c., oz. 10c., 1b. 65c. Mailing, 8c. 1b.

LONG BLACK SPANISH.-Large growing, black skinned sort, firm, white flesh, mild and crisp. Pkt. 5c., Oz. 10c., 1b. 65c. Mailing. 8c. 1b.

Similar to preceding,

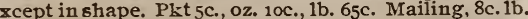
LONG WHITE SPANISH.-Pkt. 5c., oz. 10c., 1b. 65c.

Mailing. 8c, 1b. flesh white, solid, mild and excellent. Pkt. 5 c., oz. 10c., 1b. 65c. Mailing, 8 c. 1 b.
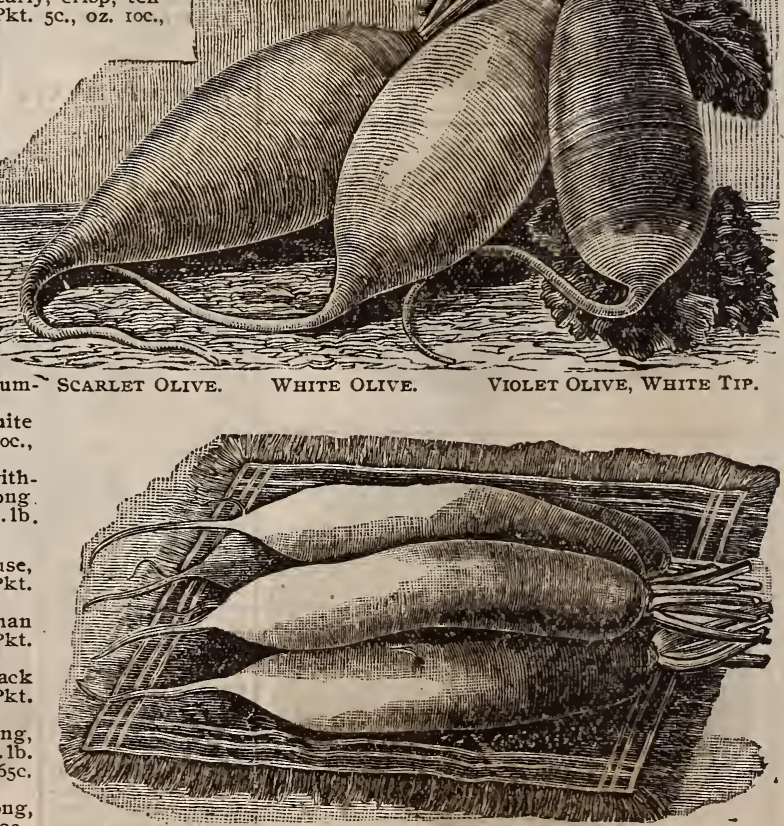

Chartier radish. 


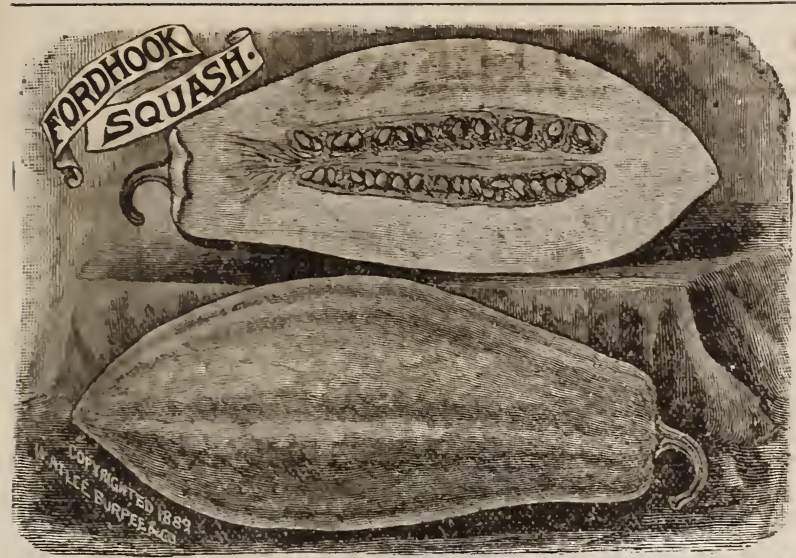

\section{HSQUASH}

SUMIIER VIIRIETIES.

NEW MAMMOTH WHITE BUSH SCAL. LOP.-Equally as early and much larger than the White Scallop, or Patty-Pan, grows 12 to 15 ins, in diameter, very uuiform aud wonderfully prolific. Pkt. 5c., Oz. 10c., 1b. 75c. Mailing, $\delta$ c. 1 b. WHITE PINEAPPLE.-Skin and flesh creamy white, very fine grained, splendid flavor, vigorous, productive; can be used quite early; good both as a summer and winter variety. Pkt. 5c., oz. 10c., 1b. $65 \mathrm{c}$. Mailing, $8 \mathrm{c}$. 1b.

PERFECT GEM.-Round, haudsome, productive, excellent quality sood both as a summez or winter variety. Pkt. 5c., oz. 1oc., 1b. 55c. Mrailing. Ec. 1b.

EARLY WHITE BUSH SCALLOP.-Cream colored, scalloped. early, productive, medium size, the best for early market, excellent shipper. Pkt. 5c.. oz. 10c., 1b. 55c. Mailing, 8c. 1b.

EARLY YELLOW BUSH SCALLOP.-Like the preceding, except n color. Pkt. 5c.. Oz. Ioc., 1b. 55c. Mailing, \&c. 1b.

The best summer variety, early and proific. skin yellow, warty, excellent quality. Pkt. 5c., oz. Ioc., 1b. $65 \mathrm{C}$

Mailing. Sc. Ib fiesh and skin yellow, rich, dry, grower, and very prolific. Pkt. 5 c., ng, 8c. $1 \mathrm{~b}$.

VEGETABLE MARROW.-

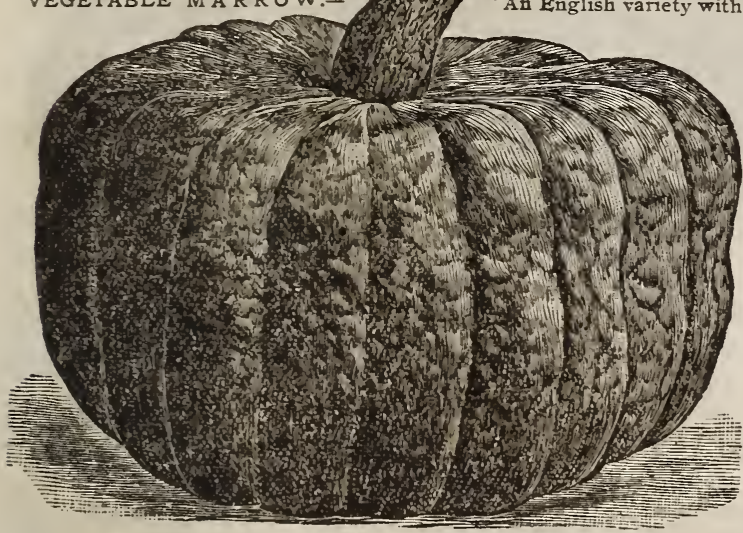

Bay State SQtash.

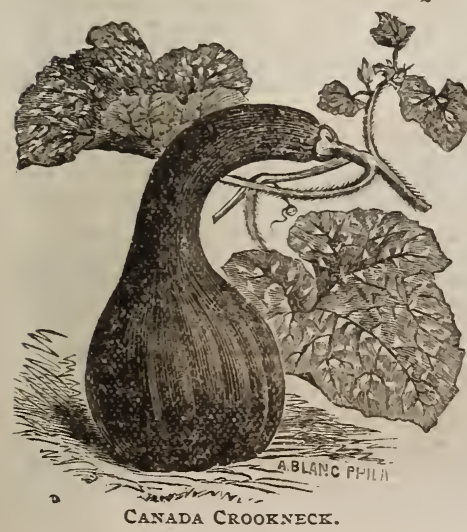

quality, fine grained sw COCOANUT,-Small, vellow, very prolific, good quality, fine grained, sweet and solid, excellent for home use. Pkt. 5c., oz. Ioc., PINEAPPIng, $8 c .1 \mathrm{~b}$. has a peculiar cocoanut a vor. Pkt. $5 \mathrm{C}$., oz. Ioc., lb. 65c. Mailing, 8c. $1 \mathrm{~b}$. flesh yellow, fine grained, sweet, excellent for winter. Pkt. 5c., oz. IOC., 1b. $55 \mathrm{c}$. Mailing, 8c, 1b. BOSTON MARROW. -A standard fall variety skin and flesh orange, rich and tender. Pkt. $5 \mathrm{c}$., oz. HUBBARD. The best winter squash. The best wrained, good, large, fne good keeper and very pop. ular. Pkt. $5 \mathrm{c}$, , Oz. IOc., lb. 55c. Mailing, \&c. 1b. That in the way. ceding but with hareceding, but aith harder winter squash . Pkt, $5 \mathrm{c}, \mathrm{oz}$. roc., 1b. 55c. Mailing, $8 \mathrm{c}$.1b.

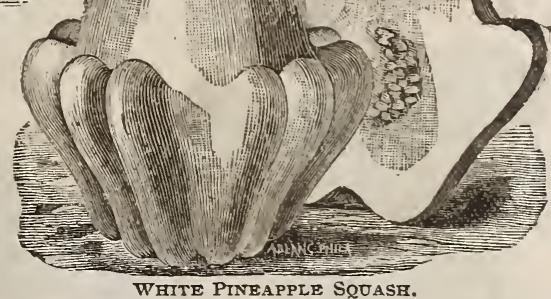

oblong yellow fruit, very rich and tender, Pkt. 5c.

FALI AND WINTER SORTS.

FORDHOOK.-The earliest of the winter squashes, bright yellow, sweet, dry, and very thick meated, immensely productive: a good keeper, handsome appearance, and splendid quality. PLt. roc., 3 SIBLEY OR PIKE'S PEAK. -A very distinct variety, hard shelled, pale green, thin, and flinty ; flesh brilliant orange, solid and thick, rich, dry, and splendid flavor. Grows to moderate size-from 8 to II lbs.-is remarkably rigorous, ripening about with the Hubbard. A splendid keeper; retaining its fine flavor, and remaining perfectly sound until the last f March. Pkt. 5c., oz, 20c., 1b. \$I.75. Mailing, 8c. 1b. VALPARAISO.-A South American variety of large size and fine quality; enormously productive, popular - a distinct acquisition. Pkt. 5c., oz. Ioc., b. 85c. Mailing, 8c. 1b. winter crookneck, small size, very productive. Pkt. c. oz. Ioc. 1b. 55c. Mailing, 8c. 1b.

TURBAN. - The best autumn squash. Pkt. 5c., oz. roc., 1b. 55c. Mailing, 8c. 1b.

LOW'S BAY STATE.-Introduced in 1888 - resembles somewhat the E'ssex Hybrid: shell very hard, color blue, very heavy and solid. Pkt. 5c., oz. Ioc., lb.

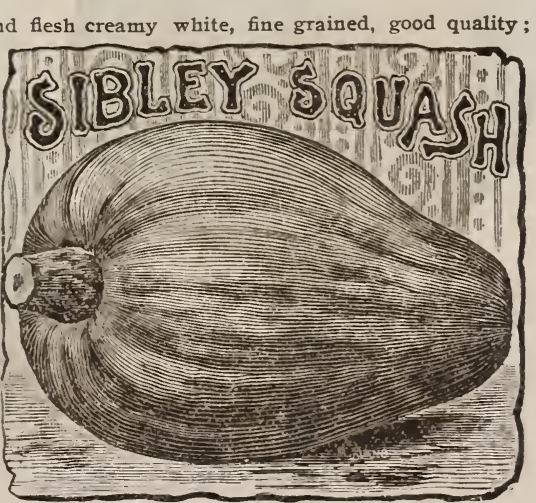




\section{SALSIFY • OR • OYSTER \&PLANT.}

White French.-The standard sort. Pkt. 5c, oz. 15c., 1b. $\$$ r.40. being grown by truckers in the vicinity of Mailing, ১c. $1 b$.

MAMMOTH SANDWICH ISLAND.-A greatly improved variety, producing roots almost double the size and weight of
the White French. Quality unsurpassed. This variety is now
ing, 8c. 1b.

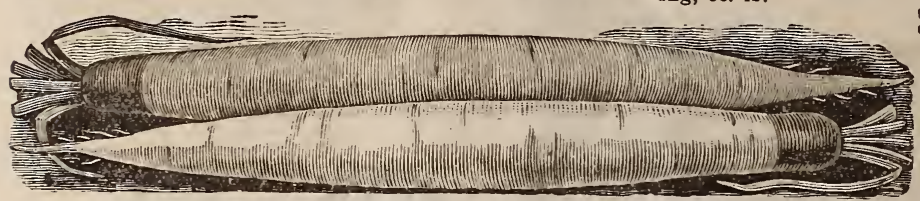

SANDWICH ISLAND MAMMOTH SALSIFY.

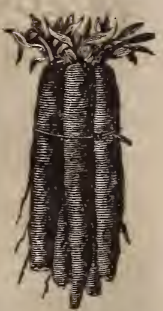

SCORZONERA.

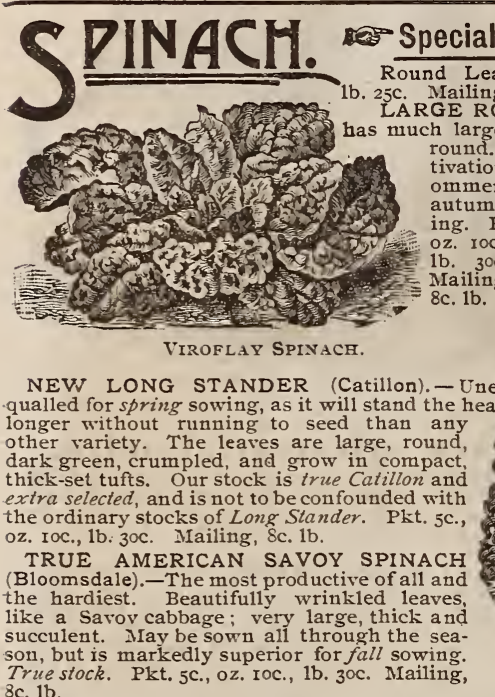

8c. $1 \mathrm{~b}$.

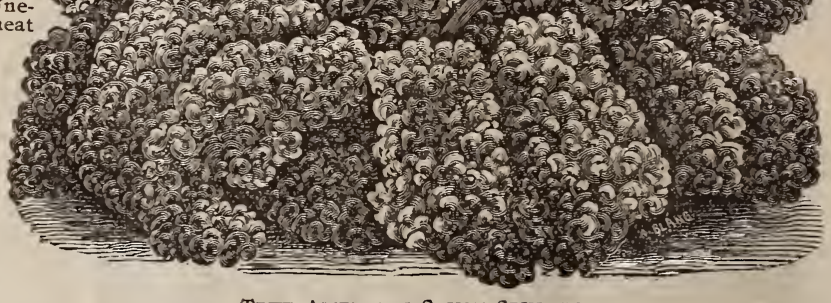

Large Prickly, or Winter.-A vigorous growing, hardy variety, for fall sowing. Pkt. 5c., oz. xoc., 1b. 25c. Mailing, 8c. 1b.

NEW ZEALAND SPINACH.- Supplies the place of ordinary spinach during the hottest months of the year, or in dry, arid localities, where the ordinary spinach does badly. The seed is sown where the plants are to stand in May, and the plants

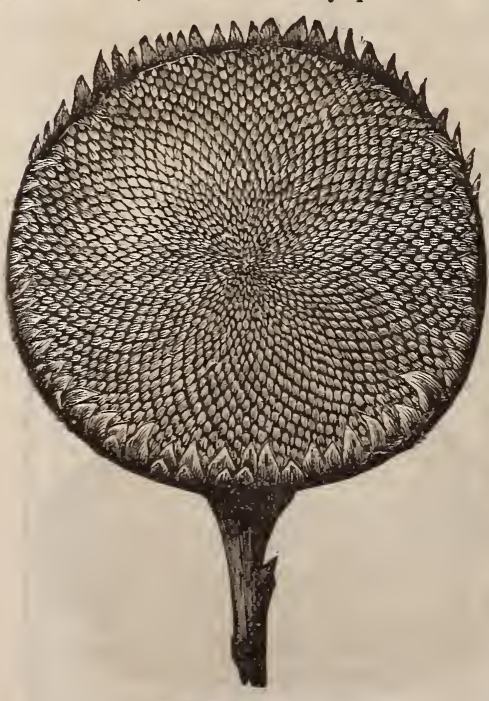

MAMMOTH SUNFLOWER yield a continuous supply of leaves with hardly any attention. Pkt. 5 c., oz. roc., MAMMOTH RUSSIAN SUNFLOWER.

The GIFNT ATIONG SuNflonzers.

This gigantic variety of sunflower will produce double the crop of any other variety. It is one of the most profitable crops; the seeds being used for poultry variety. It is one of the most profitable crops; the seeds being used for poultry
feed, and for this purpose are the best egg-producers extant. Besides this they are good for horses, and vield a considerable quantity of oil. The leaves make excellent fodder, being relished by all kinds of stock. The stalks are good for fuel, and there is absolutely no waste whatever in the whole crop, which, on an average, costs less to produce than corn. As high as a hundred and twenty-five bushels have been harvested from one acre. Pkt. 5c., qt. I5c. Mailing, Ioc. per qt. By express or freight, $\$ 2.00$ per bushel.

TOBACONNECTICUT SEED L EA F-Fitensively grown in the Eastern and Middle States for cigar
wrappers. Pkt. 5c., oz. 20c., 1b. $\$$ r.75. Mailing, 8c. 1b. HAVANA.-Saved from selected plants. Pkt. 5c., oz. 20c., 1b. \$1.75. Mailing, 8c. 1b.

Q T $\vec{R} \vec{R}$ The roots of this plant are plump and fleshy, and 11 1 1 sweet. Cooked and used as salsify. Sow in drills I 8 inches apart. Take up the roots in the fall and store them in sand or earth. Pkt. 5c., oz. 30c., 1b. \$2.00. Mailing, 8c. Ib.

- 0 R Sow in April or May, in drills 15 inches apart, and

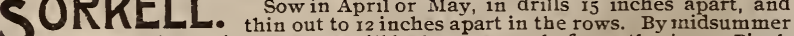
the leaves will be large enough for gathering. Pinch off the flower stalks as they appear. It is used in the $s+m e$ way as spinach, and is often mixed with that vegetable. The French are far more alive to the value of sorrel than we are, their cooks holding it in even higher estimation than spinach. Ought to be more largely grown. Pkt. 5c., oz. Ioc., 1b. 9oc. Mailing, 8c. ib. 


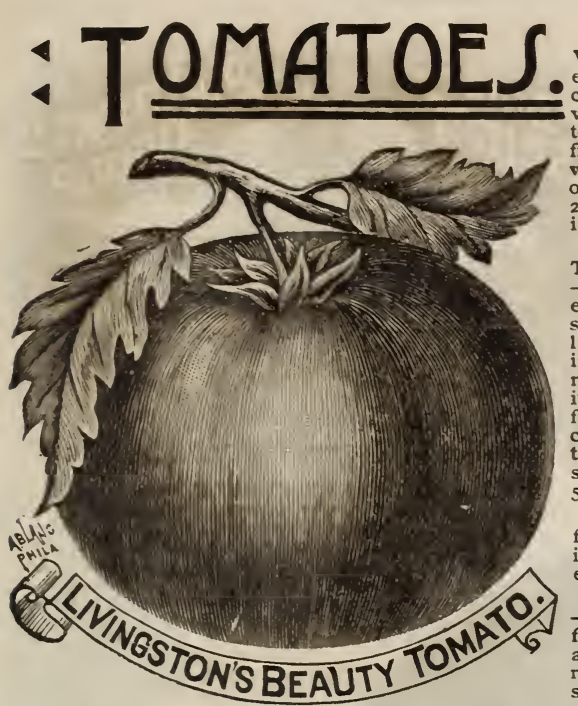

EXTRA EARLY AD.

VANCE.-One of the very SOCIETT J AMERICANFIORISTS

earliest tomatoes, of first- ECERTIFICATE OFMERIT3.

class quality and good size; Amarded me L LORI LRO TOMUTO:

very productive and continues the

fruits are bright red,

very solid, and with-
outcore. Pkt. 5c., oz.

$25 \mathrm{c}$., 1b. \$2.50. Mrail-

ing, \&c. lb.

NEW PO

TATO LEAF.

A distinctand

excellent new

sort, resemb-

ing the Acme

remarkable for

ts firmness of

ruit and fine

cropping quali-

ies ; fruits

smooth, even : seconc early, rery hardy and continuous bearer. Plt. c., oz. 20c., 1b. \$2.00. Mailing, \&c, lb.

THE SHAH.-This splendid new golden yellow tomato is a sport from the celebrated red variety-Mikado (or Turner Hybrid)-and is identical, except in coior, having the same distinct foliage, and fruits of enormous size, solidity and productiveness. Pkt. 5c., oz. 25c.

THEMIKADO

- Very large,solid.

free from core and almost seedless : skin bright red smooth. excellent smooth; excellent quality and a fine vielder. Pkt. 5c., oz. 25c., 1b. \$2.50. Mailing, ₹c. 1b. LORILLARD FORCING - POSSesses ext very uniform over the whole surface: very solid, smooth, and well flavored early, productive, handsome; a splendid variety for open air as well as

forcing. PRT. InC., Oz. $30 \mathrm{C}$. farms of Long Island, and is remarkable for size, earliness and fine quality. Skin bright red, smooth and handsone; enormously productive and very popular. We cannot recommend this variety too highly. Pkt. 5c, oz. 25c. 1b. $\$ 2.50$. Mailing, 8c, $1 \mathrm{~b}$.

BEAUTY (Livingston.)-Crimson, tinged with purple; round, smooth and glossy : excellent quality, solid and free from core, early, vigorous and a good shipper; very distinct and handsome. Pkt. 5c., oż. 20c., 1b. $\$ 2.00$.

PEACH TOMATO - This variety resembles a peach very closely and is appropriately named the "Peach Tomato." The flesh is solid, rich and finely flavored. Productive and excellent. Pkt. $5 \mathrm{c..}$. oz. $25 \mathrm{c}$.
Acme.-Medium size; early ; productive; dark rich red; solid, fine flarored. Pkt. 5c., oz. 20c., 1b. \$2.00. Mailing, 8c. 1b.

Cardinal.-Skin bright cardinal; flesh deep red, firm, solid; no core round, smooth, handsome. Plt. 5c., oz. 20c., 1b. \$2.00. Mailing, 8 c. 1b.

Trophy.-A standard medium early. Plkt. 5c,, oz. 20c., 1b. $\$ 2.00$. Mailing, \&c. 1 b.

FAVORITE,-Large early sort, resembling Perfection, but larger and darker in color. Pkt. 5C, $0 \mathrm{z}, 20 \mathrm{c}, 1 \mathrm{~b}, \$ 2,00$. Mailing, $8 \mathrm{c}$. 1b.

DWARF CHAMPION. - The distinguishing characteristic of this variety is its sturdy habit of growth, which makes the plant self-supportinga feature possessed by no other variety. Fruits purplish pink, smooth and a feature possessed by no other rariety. Fruits purplish pink, smooth and $\$ 2.50$. Mailing, 8c. 1b

PARAGON.-A large medium early ; dark red; solid; excellent quality. Pkt. 5c., oz. 20c., 1b. $\$ 2.00$, Mailing, 8c. 1b.

GOLDEN QUEEN.-Medium early: smooth, round, handsome; rery productive, and excellent quality. Pkt. 5c., oz. 25c., 1b. $\$ 2.50$. Mailing, c. $1 \mathrm{~b}$

MAYFLOWER.-Large. smooth, bright red ; fine quality ; good yielder. Pkt. 5c., oz 20c., 1b. $\$ 2.00$. Mailing, 8c. lb.

PERFECTION (Livingston). - Large, early, blood red; sweet, firm flesh of

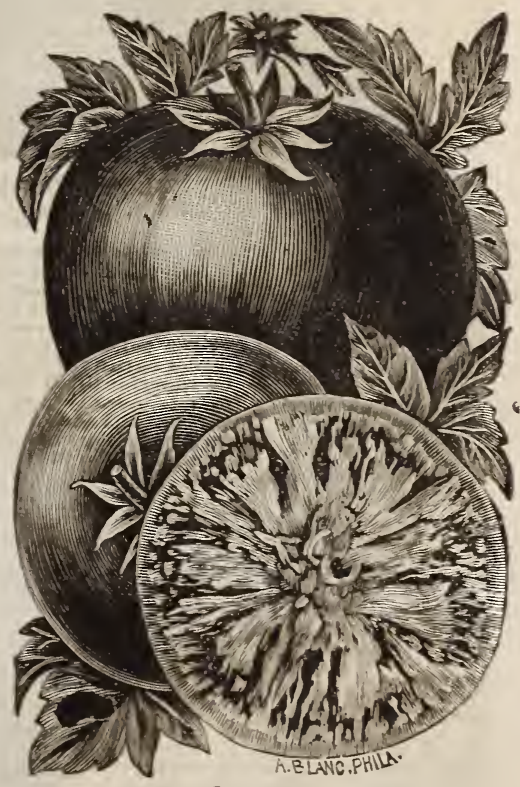

CARDINAL.

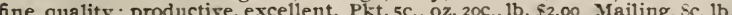

IGNOTUM (New).-Among the earliest, if not the very earliest, in cultivation ; magnificent bearer: large, sweet, handsome, deep red; very heary and solid; almost seedless; no core, splendid flavor, and does not crack or rot. There being few seeds in the fruits, the seeds are necessarily expensive. Beware of spurious seeds! Buy only from houses of gond reputation. Pkt. Ioc., oz. 75 C.

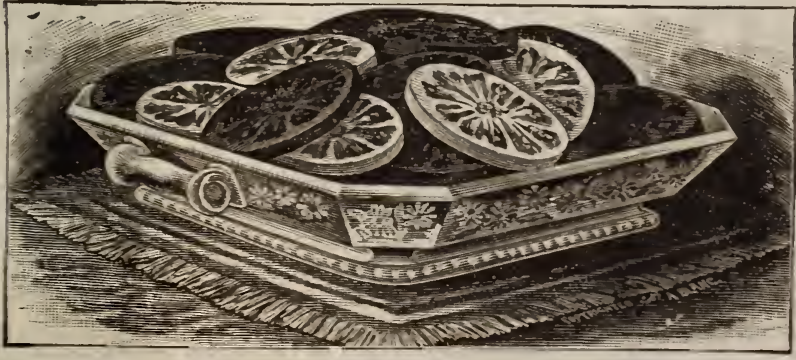

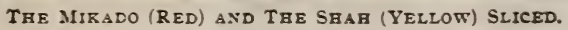
RED CHERRY.-Small red sort, excellent for preserves. Pkt. 5c., oz. 20c., 1b. $\$ 2.00$ Mailing. 8c. 1 b.

YELLOW PLUM.-Small, bright yellow: oval: for preserves. Pkt. 5c., oz, $30 \mathrm{c}, 1 \mathrm{~b}$ \$3.00, Mailing, ${ }^{\text {C }}$. TOMATO (Ground Cherry)-(Alkekengi). - Small fruit, about the size of a cherr. $*$ used for preserves. Pkt 5c., oz. 30c., 1b. $\$ 3.00$. Mailing, 8c. $1 b$.

\section{(i)}

Alternate slices of Red and Yellow Tomutoes make one of the most ornamental dishes that can be put on the table.

Try the Shah and the Mikado. Maguificent Red and Yellow sorts. 8. 


\section{TURNIPS $\equiv$}

Our seeds are grown from selected, trans. planted roots, thoroughly rogued during growth, and grown and harvested with great care. Customers can saze time and exxpense by ordering their turnip seeds along with their general order.
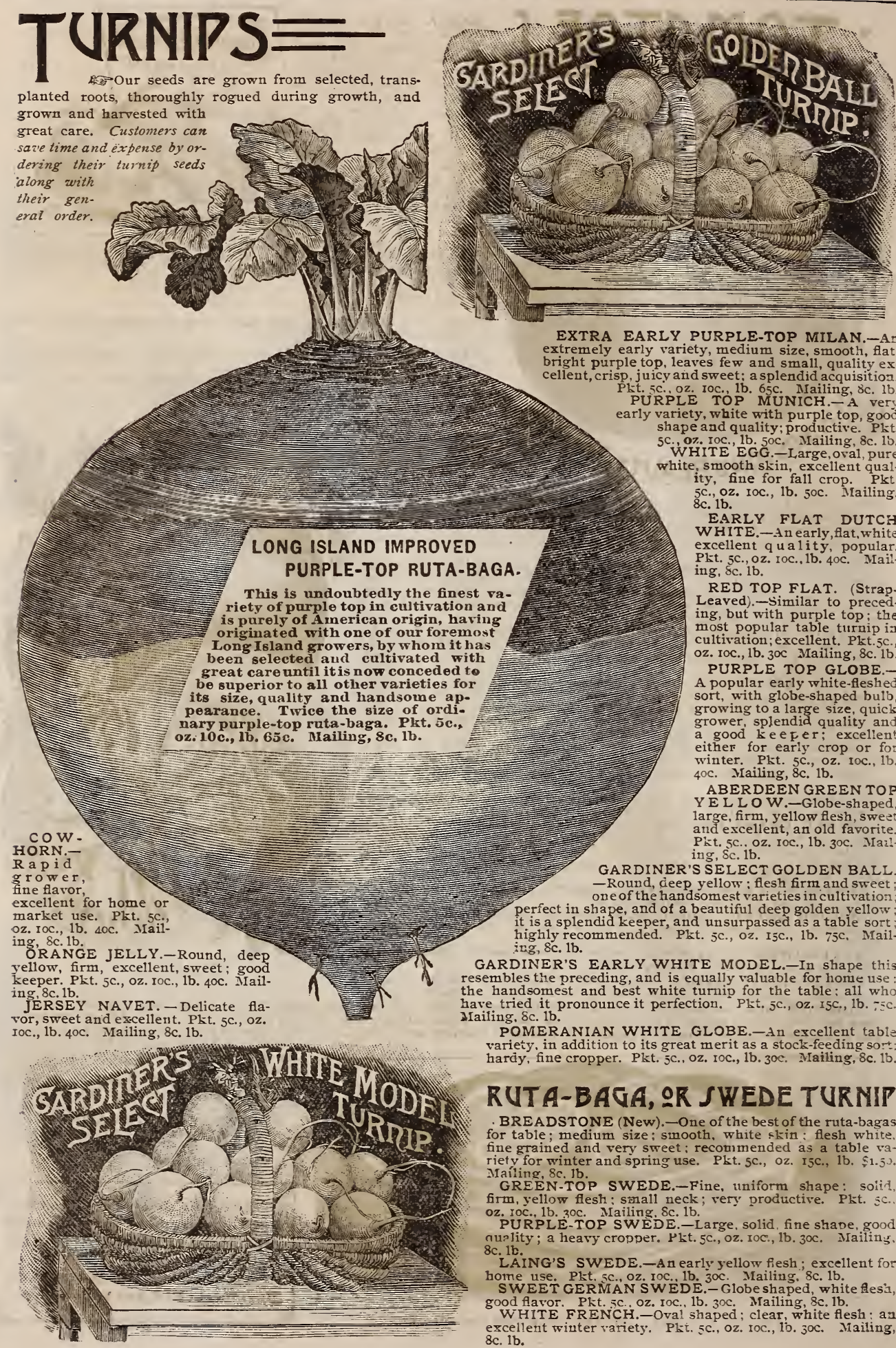

EXTRA EARLY PURPLE-TOP MILAN.-An extremely early variety, medium size, smooth, flat, bright purple top, leaves few and small, quality exPLt. 5c. Oz. Ioc. $1 \mathrm{~b} .65 \mathrm{c}$. Nailing, 8c. $1 \mathrm{~b}$.
PURPLE TOP MUNICH.-A ver: early variety, white with purple top, good shape and quality; productive. Plt. 5c., 07. Ioc., 1b. 50c. Mrailing, 8c. 10. WHITE'EGG.-Large, oval, pure white, smooth skin, excellent quality, fine for fall crop. Pkt. 5 c., oz. IOc., lb. 50c. Mailing,

EARLY FLAT DUTCH WHITE.-An early, flat, white excellent quality, popular. Pkt. 5c., oz. Ioc., 1b. 4oc. Mailing, $8 \mathrm{c}$. $1 \mathrm{~b}$.

RED TOP FLAT. (StrapLeaved).-Similar to preceding, but with purple top; the most popular table turnip in cultivation; excellent. Pkt. $5 \mathrm{c}$. oz. Ioc., 1b. $30 \mathrm{c}$ Mailing, $8 \mathrm{c}$. $1 \mathrm{~b}$ PURPLE TOP GLOBE.A popular early white-fleshed sort, with globe-shaped bulb growing to a large size, quick grower, splendia quality and a good keefer; excellent either for early crop or fo winter. Plt. 5c., oz. 10c., $1 \mathrm{~b}$. 40c. Mailing, 8c. $1 \mathrm{~b}$.

ABERDEEN GREEN TOP YE L L O W.-Globe-shaped, large, firm, yellow flesh, swee and excellent, an old favorite. Pkt. 5c. Oz. Ioc., 1b. 30c. NIazing, Sc. ib.

GARDINER'S SELECT GOLDEN BALL. - Round, deep yellow : flesh firm and sweet - Rout te dep yellow : flesh firm and sweet perfect in shape, and of a beautiful deeo golden vellow perfect in shape, and of a beautiful deep golden yellow : highly recommended. Pkt. $5 \mathrm{c}$., Oz. I5c., 1b. $75 \mathrm{c}$, Mailing, 8c. 1b.

GARDINER'S EARLY WHITE MODEL-In shape this resembles the preceding, and is equally valuable for home use: the handsomest and best white turnip for the table: all who have tried it pronounce it perfection. Pkt. $5 \mathrm{c}$., oz. I5c., 1b. $-z \mathrm{c}$ Sc. $1 \mathrm{~b}$

POMERANIAN WHITE GLOBE.-An excellent table variety, in addition to its great merit as a stock-feeding so:hardy, fine cropp

\section{RUTA-BAGA, OR SWEDE TURMIP}

BREADSTONE (New).-One of the best of the ruta-bagas for table medium size: smooth, white skin : flesh white fine orained and rery sweet: recommended as a table va riety for winter and spring use. Plt. 5c., oz. 15c., 1b. $\$ 1.53$ Maíling, 8c, lb.

GREEN-TOP SWEDE.-Fine, uniform shape: soil firm, yellow flesh: sinall neck; very productive. Pkt. sc.

Oz. IOc., 1b. 30c. Mailing, Sc. 1b. aus lity; a heavy cropper. Pltt. 5c., oz. Ioc., lb. 3oc. Mrailiny. LAING'S SWEDE.-An early yellow fiesh; excellent for home use. Plt. $5 \mathrm{c}$., oz. Ioc. 1b. 3oc. Mailing, 8c. 1b.

SWEET GERMAN SWEDE. -Globe shaped, white flesi, good flavor. Pkt. 5c. oz. Ioc., 1b. 30c. Mailing, 8c, 1b.

WHITE FRENCH.-Oval shaped; clear, white flesh : an excellent winter variety. Pkt. sc., oz. 1oc., lo. joc. Mailing $8 \mathrm{c} .1 \mathrm{~b}$. 
OS SWEET, POT AND MEDICINAL HERBS, AND SUNDRY VEGRTABLES \%:

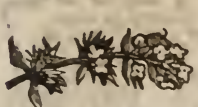

THYME (Thymus vulgaris) - A highly aromatic
herb, the young tops and soups, stuffings and sauces. Pkt. 5c., oz. $30 \mathrm{c}$.

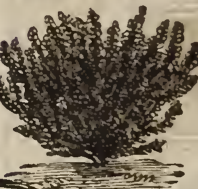

FRENCH THYME.

(1)
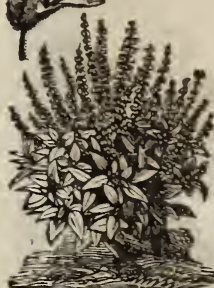

BASIL, SWEET.
CONOTER's CoLos-

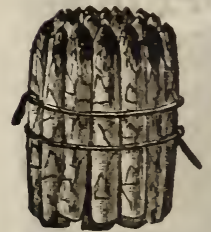
SAL ASPARAGUS. mum minimum). - The leafy tops have a strong flavor of cloves, and are used in highly seasoned dishes, and sometimes in salads and soups. Pkt. 5C., Oz. 20C.

\section{BASIL, SWEET}

(Oc y $\mathrm{m} \mathrm{u} \mathrm{m}$ basilicum).-A larger growing variety of the pOR : 1kt. 5c, oz. 20c.
BASIL, BUSH

\section{MAR JORA M} SWEET (Origanum marjorana).-A very relishing herb, with a sweet, aromatic flavor; much used in soups and stuffings. The tops and leaves dry state. Pkt. $5 \mathrm{c}$., Oz. $25 \mathrm{c}$.

MARJORAM, POT (Origanum onites).-A perennial variety of marjoram, used in the same way as the preceding. Pkt. 10c., oz. 40c.

SAGE (Salvia officinalis) -The leaves are used in sauces and stuffings, and to improve cookery. Pkt. 5c., oz. $20 \mathrm{c}$. -Used green in the same way as, and by many 1b. \$1.40. Mailing. 8c. 1b. SAGE.

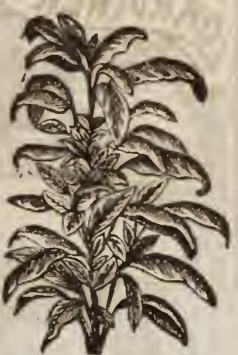
Anise, Borage, Bene, Burnet, Caraway, Coriander, Dill, Fennel, Pot Marigold, Summer Savory, inter Savory, Wormwood. All 5c. per pkt., 20c. per oz.

Arnica, Balm (Melissa), Catnip, Horehound, Hyssop, Lavender, Lovage, Pennyroyal, Rosemary, Rue, Woodruff (Maitrank). All loc. per pkt., $50 c$. per oz.

\section{$\triangle \triangle$ MISCELLANEOUS VEGeTABLES $\triangle \Delta$}

ARTICHOKE, GREEN GLOBE.-A large, very highly-flavored variety.

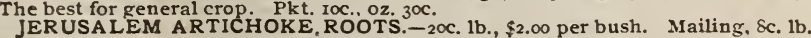
MARTYNIA.-The seed pods, when young, are used for pickles, and by many are considered superior to the cucumber itself. Pkt. 10c., oz. $35 \mathrm{c}$.

NASTURTIUM.-The young seed pods are much esteemed for capers making very delicate pickles. Running vine of the easiest culture. A full assortmen

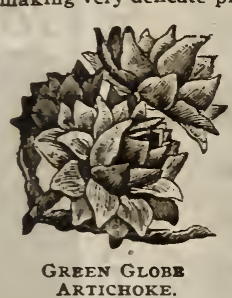
of the large flowering and beautiful colored varieties will be found under LARGE-SEEDED PICKLING.The farorite pickling sort. Pkt. 5c. oz. 15c., lb. \$1.00. Mailing, 8c. lb.

SCOLYMUS.-A vegetable used in the same way as Salsify. Pkt. 5c., 0z. 20C.

COllards, OR COLEWORT.

Almost any variety of green cabbage will make good collards, but the strain known as "Georgia Collards" is the popular sort in the South.

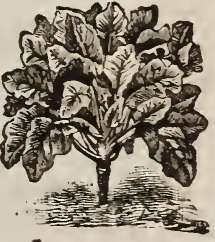

Collards or

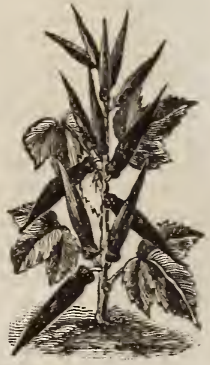

IMPROVED DWARE
GEORGIA COLLARDS.-True. Pkt, 5c, oz, Ioc, 1b, goc, Mailing, $8 \mathrm{c}, 1 \mathrm{~b}$

ASPARAGUS, conover's coLosSAL.-The, OKRA, OR GUMBO.-A very popular plant in the standard sort. Pkt. 5c., oz, 10c., 1b. 5oc. Mailing, 8c. 1b. Two- South for stews and soups.

Year-Old Roots, by express, $\$ 1.00$ per $100, \$ 5.00$ per 1,000 .

BARR'S MAMMOTH.-A magnificent new variety, large, productive, superior quality, a great acquisition. Two-YearOld Roots, by express, per $100 \$ 1.50$, per $1,000 \$ 6.00$.

MUSTARD, WHITE.-The best for salads ; the seeds are also used for mixing with pickles and for preserving cider. Pkt. $5 \mathrm{c}$., oz. IOc., lb. $40 \mathrm{c}$. Mailing, 8c, 1b.

BROWN.-The mustard of commerce; more pungent than the white for th is purpose. Pkt. 5c., 0z. Ioc., lb. 40c. Mrailing, 8c.1b. Improved Dwarf Early.-Pkt. 5c., oz. Ioc., lb. 5oc. Mailing, 8c. 1b. with smooth, round pods of a white, very distinct new variety, extra large and very productive. Plet $5 c$. Ioc., 1b. 85 c. Mailing, 8c. 1b.

CHICORY. LARGE-ROOTED.-The chicory of commerce, also makes a good salad by blanching the leaves. Pkt. $5 \mathrm{c} ., 0 z$ . Ib. 8oc. Mailing, $8 c$.

"WITLOOF," OR LARGE-ROOTED BRUSSELS.-EXcellent, both as a salad and vegetable. In the fall the roots are for salads in the South. Pkt. 5c., 0z. 10c., lb. 9oc. Mailing, $8 \mathrm{c}$. 1b.l taken up, the leaves cut off and the roots

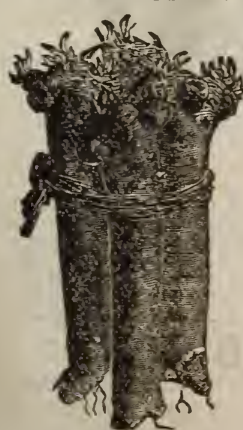

HORSERADISH
R H U B ARB, VICTORIA -Pkt. 5c., \$1.75. Mail $t_{x \rightarrow}$ Roots by express, $\$ 2.00$ per per Ioo LINNAEUS. - Pkt. SC., $02,25 \mathrm{C}$ Mailing, $8 \mathrm{c}$ 1b. Roots yy express, $\$ 2.00$ per per 100.

HORSERADISH .-xice large roots, 6 inches long, 5c. each, foc. per doz. Mailing, 5c, doz.

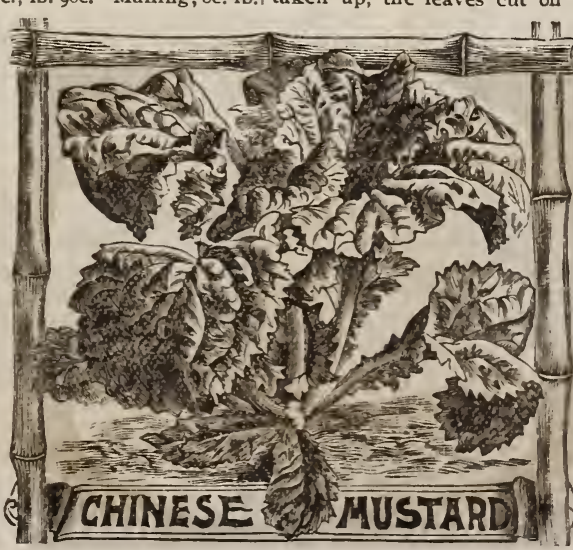
planted one

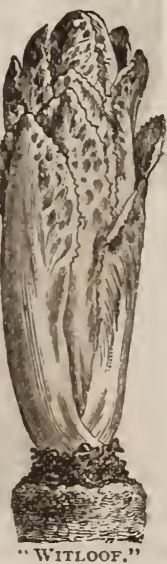




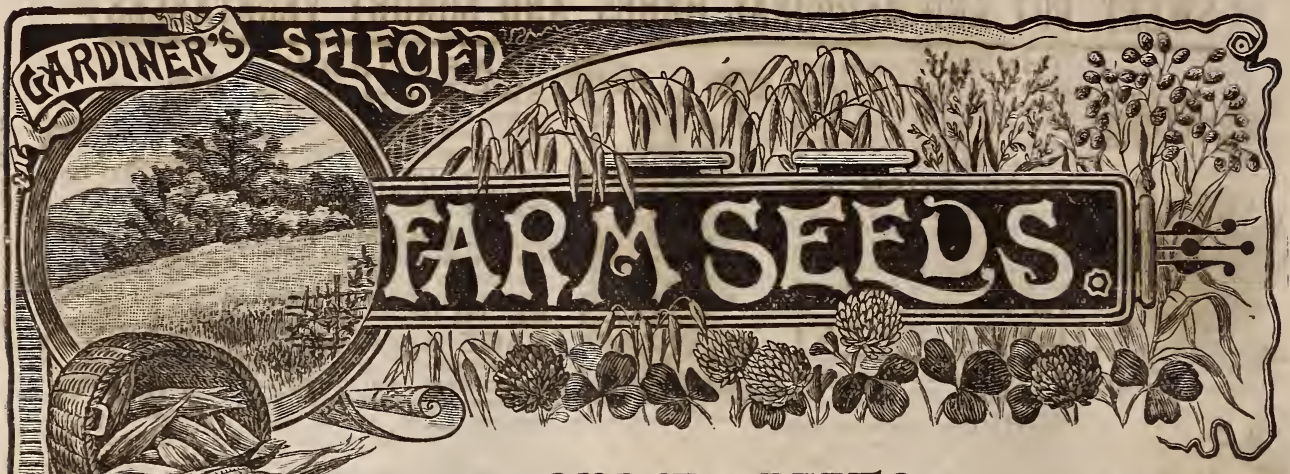

\section{$\triangle$ SUGAR A BEETS A}

IMPROVED WHITE SUGAR BEET.-Does not grow
quite so large as the mangels, but is much sweeter, and

\section{MANGEL-WURZEL.}

The following varieties are grown entirely for feeding stock, and are one of the most important and valuable crops on which the farmer has to
depend for a plentiful supply of fresh and healthful stock feed. From a single acre of land in good condition, 30 or 40 tons are frequently harvested, and exceptional crops of 50 and even 60 tons are reMAMMOTH LONG RED MANGEL.-Very large and productive; a much improved strain. MAMMOTH LONG YELLOW MANGEL.Similar to preceding, except in color. Pkt. 5c. KINVER YELLOW GLOBE.-Bright yellow, large, productive, profitable, fine quality. Pkt. $5 \mathrm{C}$. Oz. IOC, 1b. 40c. Mrailing, 8c. 1b.

fine keeper. Pkt. 5c.

GOLDEN TANKARD MANGEL.Bright yellow, large, handsome, heavy cropper, splendid quality; one of the finest mangels; as

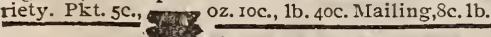

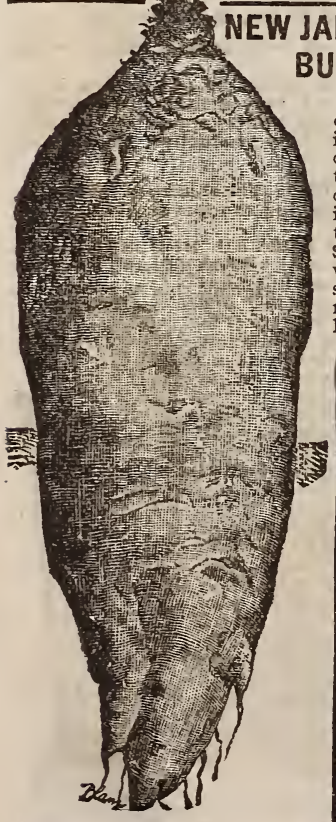
proving the quality and yield of the r.ilk. Extensively grown for making sugar. Pkt. $5 \mathrm{c} ., \mathrm{Oz}$. Ioc., 1b. 5oc. Mrailing, 8c. 1b. Sul wHITE SUGAR BEET - A French variety, superior to all others in sugar-producing qualities; very popular. Pkt. 5c. oz. roc., 1b. $65 \mathrm{c}$. Mailing, $8 \mathrm{c}$. $1 \mathrm{~b}$.
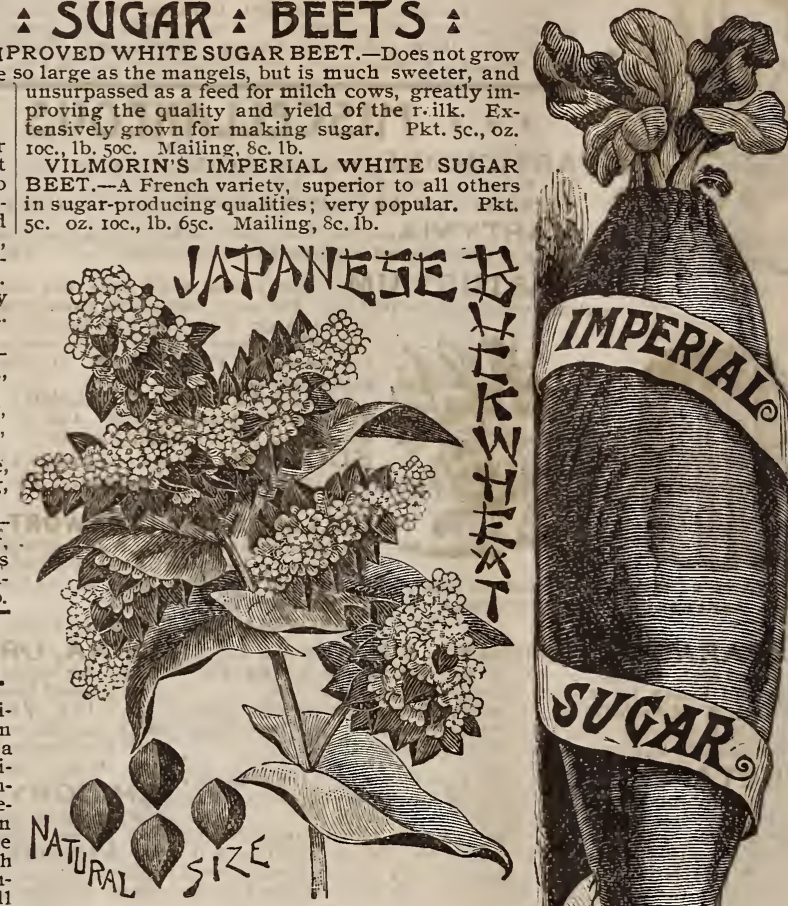
if
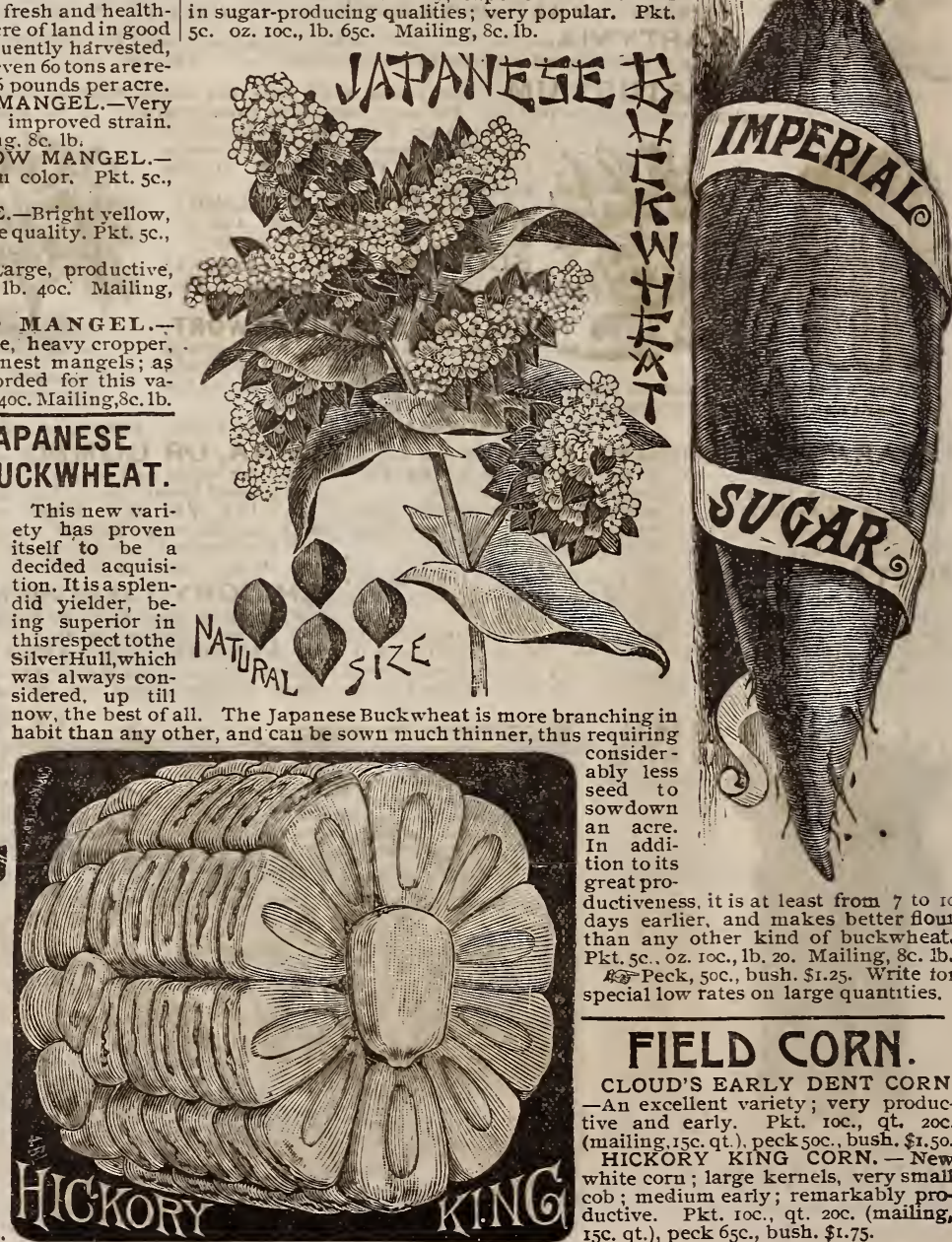
ably less seed to an acre. tion to its great productiveness, it is at least from 7 to 10 days earlier, and makes better flour than any other kind of buckwheat. Pkt. 5c. oz. Ioc., 1b. 20. Mailing, 8c. 1b. Peck, 50c., bush. \$1.25. Write to special low rates on large quantities.

FIELD CORN.

CLOUD'S EARLY DENT CORN. -An excellent variety; very productive and early. Pkt. 'roc., qt. $20 \mathrm{C}$ (mailing, 15c. qt.). peck 5oc., bush. \$r.50. HICKORY KING CORN. - New white corn ; large kernels, very small cob; medium early; remarkably pro
ductive. Pkt. 1oc., qt. 20c. (mailing I5c. qt.), peck 65 c., bush. $\$ 1.75$. 


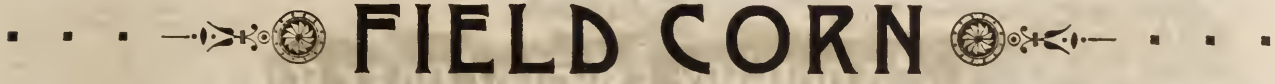 \\ Mailing Sc. 1b., Isc. qt. additional to undernoted prices.}

SELF-HUSKING.-The husks of this sort open naturally half-way down the ear. Pkt, Ioc., pint 15c., qt. 25c. $\$ 4.00$ per bush., \$1.25 per peck.
LEAMING.-Sma $11 \mathrm{cob}$, deep grains; reliable, productive. $\mathrm{Pkt}$ 10c., pint 15c., qt., 25c. \$1.50 per

PRIDE OF THE NORTH.-The earliest Dent Corn for the North. Pkt. roc., pint 15c., qt. $25 \mathrm{c}$., bush. $\$ 1.50$, peck $50 c$.

CHESTER CO. MAMMOTH.The best Dent Corn for the South and West. Pkt. 10c., pint $15 \mathrm{c}$., qt.

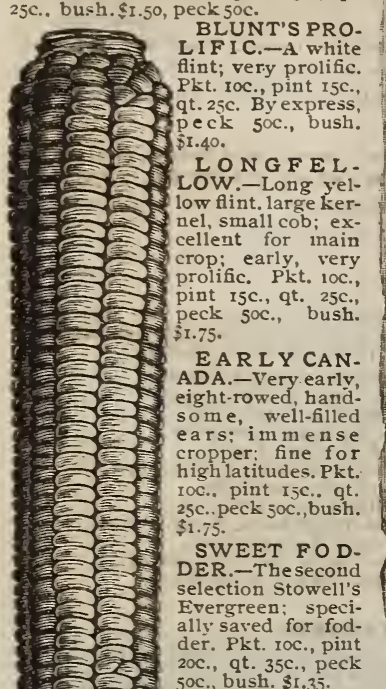

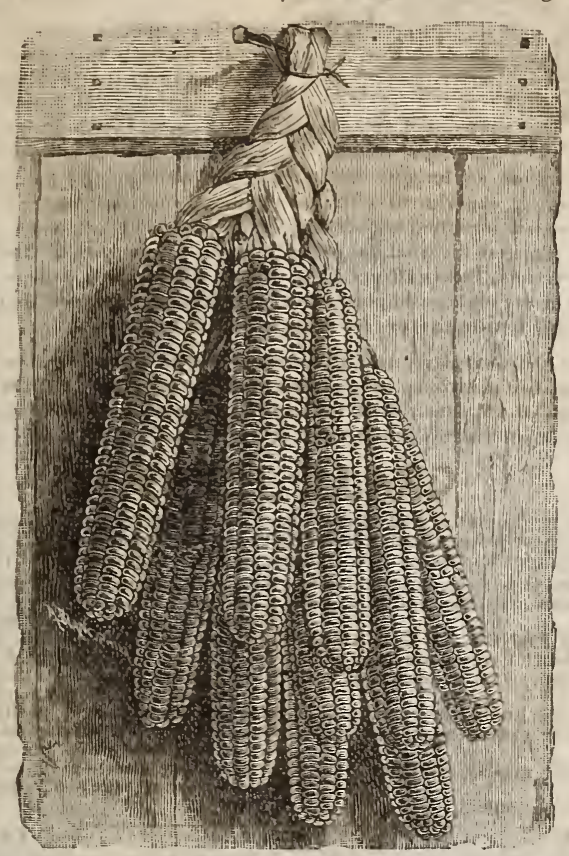

EARLy Canada CORN.

\section{KAFFIR CORN.}

, distinctly different in habit of growth and other characteristics from all others of that ing only six feet high in rich soil, stocky, perfectly erect; the foliage is wide, alternating closely on either side the stalks. It does not stool from the root, but branches from the top joints, producing from two to four heads of grain from each stalk. The leads a re long, narrow, and perfectly erect, well filled with white grain. The whole stalk, as well as the blades, cures into excellent fod der, ¿nd in all stages of its growth is a vailcattle mules and horses being equally fond of it. If cut down to the ground two or more shoots root, and the growth is thus maintained until checked by frost. It has the quality common to all the ing drouth. If the growth is checked by want of moisture, the plant waits for rain and then at once resumes its proces ses. Pkt. Ioc., 1b. 30c., 100

\section{PEAS.}

CANADA FIELD. Valuable for North GOLDEN DENT.-Grains very deep; cob/ern climates for cattle feeding. Qt. 20c., bush. bright red, extremely small, and well filled. Early, prolific, easy to shell; does not harden too much; nutritious and easily digested; very popular, and highly recommended. By mail, pkt. roc., qt. 25c, peck 50c, bush. \$1.50.

\section{GRAINS.}

IIFIC CORN. BARLEY, (481bs, to bushel.)-

and prolific. Qt. $20 \mathrm{c}$. .. bush. \$r.40.

American Silver Hull. - Earlier and more productive than

the common. Qt. $20 c$., bush. $\$ 1.00$.
OATS. (32 lbs. to bushel.)

Welcome. Heavy grain and very productive, Ot. 15c., bush. \$I.00.

White Russian.-A standard, early productive sort. Qt. I5c., bush. \$1.00.

Clydesdale. - Very

early and remarkably heavy. Qt. $15 \mathrm{c}$., bush. \$1.50.

RYE. (56 lbs, to bushel.) S p ring. - Ot. $15 \mathrm{c}$., bush. $\$ 1.75$. Winter Excelsior.-Qt. I5C., bush. $\$ 1.50$.

WHEAT.(6olbs.to bush.)

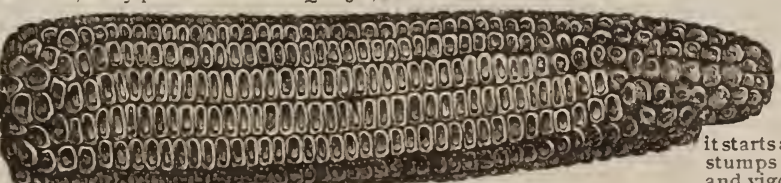
stumps with remewed strength and vigor: thrives in the hottest
and driest localities. This is one of the most valuable of all forage plants for tropical climates.

GOLDEN DENT CORN

RURAL BRANCHING S O R G U M (Millo Maize). - This non-saccharine Sorghum was introduced a few years

\section{Mediterranean}

TEOSINTE (

A valuable fodder plant from Central America, for all of our Southern States. Oz. 15c., 1b. \$1.50,

\section{SORGHUM.}

YELLOW BRANCHING SORGHUM.Is tall, nine to twelve feet, stooling from the ground like the Rural Branching or Millo Maize, but not so much. It sends out shoots to great size on good land, often weighing three-fourths of a pound, sometimes a full pound after being fully ripe. These heads are set close

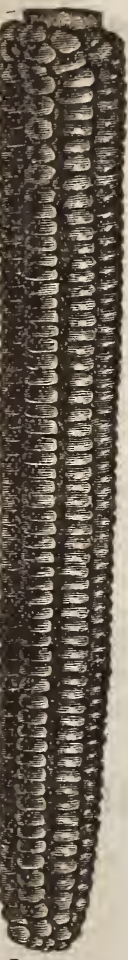

LONGFELsize of White Millo, and of deep golden-yellow color. It possesses all the vigor and vitality of other Sorghums. It is nonfeed and or green feed or curch is mules. horses, cows and hogs. This sort is earlier than the Rural Branching variety. L, b. 35c., I00 1bs. \$15.00. (Bearded).-Winter. Qt. I5c., bush. \$t.50. Armstrong or $35 \mathrm{C}$., roo lbs. \$15.00. Landreth (Beardless). - Winter. Qt. I5c., bush. \$2.00. New York Spring,-Spring. Qt. I5c., bush. $\$ 2,00$. White Russian (Beardless).-Spring. Qt. $20 \mathrm{C}$., bush. $\$ 2.50 . \quad$ Saskatchewan
(Beardless).-Spring. Ot. 20c., bush. 2.50 . Scotch Fife (Beardless).-Spring. Qt. 20c., bush. \$2.50.

BROOM CORN, Plant in rows 3 feet apart, and IMPROVED EVERGREEN.The best variety. Pkt. Ioc., pint $20 \mathrm{c}$., qt. $35 \mathrm{c}$., bush. $\$ 4.00$, peck $\$ 1.25$. 

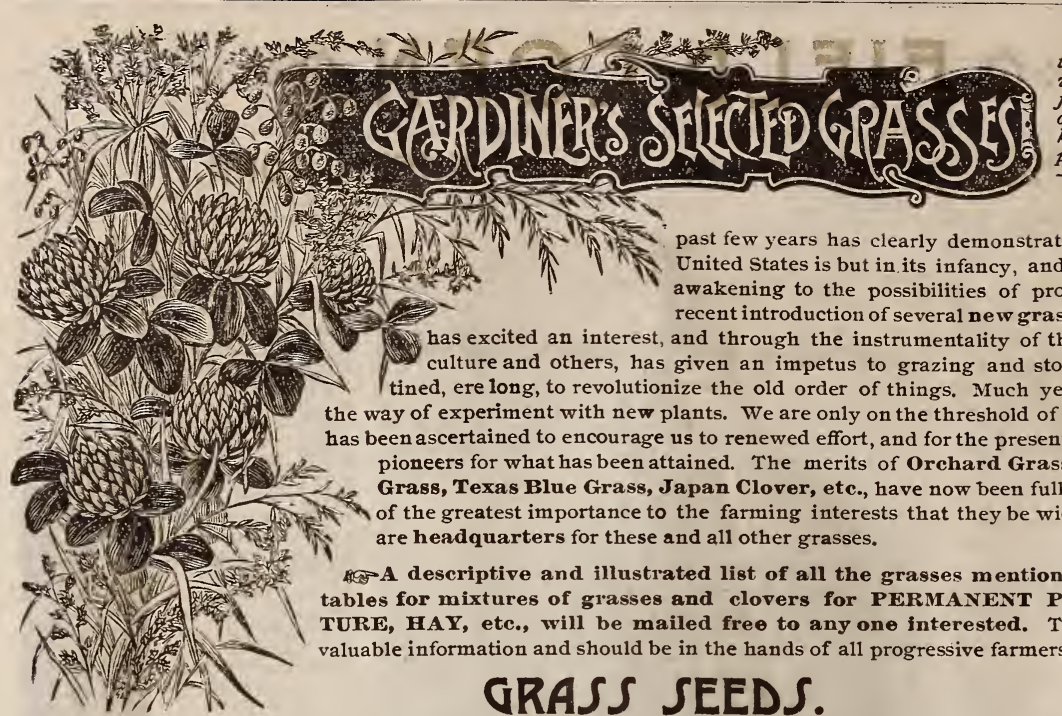

"The man whocan make two blades of grass grow where only one grea before, will deserve better of his country and mankind than all the race of -DEAN SWIFT.

The experience of the past few years has clearly demonstrated that farming in the United States is but in its infancy, and that we are only just awakening to the possibilities of profit in the future. The recent introduction of several new grasses and forage plants

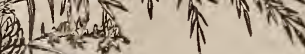
has excited an interest, and through the instrumentality of the Department of Agri-
culture and others, has given an impetus to grazing and stock feeding that is destined, ere long, to revolutionize the old order of things. Nuch yet remains to be done in the way of experiment with new plants. We are only on the threshold of discovery, but sufficient has been ascertained to encourage us to renewed effort, and for the present we are thankful to the pioneers for what has been attained. The merits of Orchard Grass, Lucerne, Johnson Grass, Texas Blue Grass, Japan Clover, etc., have now been fully established, and it is of the greatest importance to the farming interests that they be widely disseminated. We are headquarters for these and all other grasses.

$A$ descriptive and illustrated list of all the grasses mentioned below, containing tables for mixtures of grasses and clovers for PERMANENT PASTURE, LEY PASTURE, HAY, etc., will be mailed free to any one interested. This list contains much valuable information and should be in the hands of all progressive farmers.

\section{GRASS SEEDS.}

AST The prices here given are those holding at first of January and are subject to variation during the season. do not bind ourselves to fill orders at these prices should the market vary; but customers can depend on receiving lowest market rates at all times. Those desiring samples for trial only will please add $8 \mathrm{c}$. per pound to the pound prices for mailing.

Timothy $-45 \mathrm{lb}$. per bush. three grades, $\$ 1.75, \$ 2.00, \$ 2.50$ per bush. | Ryegrass English $-241 \mathrm{lb}$. per bush. $\$ 2.50$ per bush.

Red Top-Io 1b. per bush. three grades, 50c., 80c. and $\$$ I.20 per Ryegrass Italian $-181 \mathrm{lb}$. per bush. $\$ 3.00$ per bush. bush

GARDINER'S STAR h BRAND FANCY RE-CLEANED RED TOP.-Entirely free from chaff. Every pound will go as far as three of ordinary Red Top. Try it once and see. Per 1b., I5c.; per 100, \$12.00.

Rhode Island Bent-I2 $\mathrm{lb}$, per bush. one grade, $\$ 2.50$ per bush.

Kentucky Blue-r 1 lb. per bush. three grades, $\$ 3.00, \$ 3.50, \$ 4.00$ per bush.

Orchard Grass-14 lb. per bush. three grades, $\$ 1.85, \$ 2.15, \$ 2.50$ per bush.

Fowl Meadow-io lb. per bush. $\$ 2.25$ per bush

\section{MILLETS.}

Tall Oat Grass-12 lb. per bush. $\$ 3.50$ per bush.

Tall Fescue-I6 1b. per bush. $\$ 3.75$ per bush.

Fine-Leaved Fescue-ro lb. per bush. $\$ 3.75$ per bush.

Hard Fescue-16 lb. per bush. $\$ 2.00$ per bush.

Meadow Foxtail-5 1b. per bush. \$1.50 per bush.

Rough Stalked Meadow-20 1b. per bush. $\$ 6.25$ per busth.

Wood Meadow $-18 \mathrm{lb}$. per bush. $\$ 4.85$ per bush.

Wood Meadow $-181 \mathrm{~b}$. per bush. $\$ 4.85$ per bush.
Crested Dog's-tail $-301 \mathrm{~b}$. per bush. $\$ 9.00$ per bush.

Sweet Vernal [true] -6 1 b. per bush. $\$ 3.00$ per bush.

per bush.
German or Golden Millet-50 1b. per bush. three grades, \$1.Io, \$1.30, \$1.50'per bush.

Hungarian Millet $-48 \mathrm{lb}$, per bush. three grades, \$1.00, \$1.20, I.40 per bush.

\section{CLOVERS.}

Choice Red Clover-three grades, $81 / 2,9^{1 / 2}$, I I cts. per lb. Alsike or Swedish Clover-three grades, 18, 20, 25 cts. per $1 \mathrm{~b}$. Lucerne or Alfalfa-three grades, 18, 20, $22 \mathrm{cts}$. per $1 \mathrm{~b}$. White Clover-three grades, 20, 25, $30 \mathrm{cts}$. per $1 \mathrm{~b}$.

White Clover-three grades, $20,25,30$ cts. per $1 \mathrm{~b}$.
Saintfoin Clover-three grades, 12, 14, I8 sts. per $1 \mathrm{~b}$.

\section{SPECIAL GRASSES AND CLOVERS FOR THE SOUTH AND WEST.}

\section{GRASSES.}

Bermuda Grass (Cynodon dactylon).-There is probably no grass so valuable as this for summer pasture in the Southern States. It is unsurpassed for nutritious quality, and the yield per acre is very large-two and a half to four tons. It is very easily cultivated, stands the drought well, and gives splendid green pasture for eight months in the year. Sets by mail, post-
paid, 75c. per $1 \mathrm{~b}$.; by express or ifreight, $\$ 4.00$ per bush.; $\$ 8.00$ paid, 75

Louisiana Grass (Paspalum dilatatum). - A valuable pasture grass, furnishing excellent green feed at all seasons of the year, except in the very coldest weather. Grows from two to five feet nigh, and succeeds well on dry soil. Has very long roots, and resists drought remarkably. Will bear trampling better than Johnson grass. Propagated by seeds and sets. Price of sets, 75c. per I00; $\$ 6.00$ per I,000. Seed 75c. per pint.

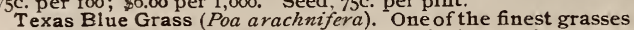
for winter pasture in the Gulf States, furnishing a rich green pasture, not unlike the Kentucky Blue Grass, from October to May. Texas Blue Grass for winter and Bermuda Grass for summer pasture have now taken their rank as standbys for Southern farmers. It can be eaten quite close five or six times during the winter-one acre of this grass being sufficient to keep four head of stock. Sets by express, $\$ 3.00$ per 1,000 ; sets by mail,

50c. per IOO. ing more popular every year, not only with farmers South and West,but also as far north as New Jersey. In Texas and other cattle-producing States farmers are planting largely increased a reas tle-producing States farmers are planting largely increased areas value they place on it. It has broad, rich green foliage, and bevanging to the Sorghum family it is very rich in saccharine matter and makes most excellent hay for all kinds of stock. By mail, post-paid, $30 \mathrm{cts}$. per pound; by freight or express, haif bush., $\$ 1.60 ;$ bush., $\$ 3.00 ; 4$ bush. at $\$ 2.70$ per bush.

\section{CLOVERS.}

JAPAN CLOVER (Lespedezia striata). -This valuable clover is not a new discovery, but has heretofore been so scarce that seeds of t in commerce were rarely to be met with. It is more nutritious than red clover, and makes splendid hay. All kinds of stock relish it to a remarkable extent, and if it were not for the scarcity
of the seed this variety would be very largely grown. Grows well on almost any soil and we believe it is destined to be the staple forage plant for pasturing in the South. We cannot recommend it too highly. We have a limited quantity of seed on hand, and as long as stocks hold out, will sell at the following prices : By mail, post-paid, 40 cts. per lb.; by express or freight, Io lbs. (sufficient for one acre) for $\$ 3.00 ; 50$ lbs., $\$ 12.00$.

Melilotus or Bokhara Clover (Honey Plant; Melilotus alba).Grows vigorously on the poorest soil and possesses valuable properties as a fertilizer. Extensively grown in the South, both for grazing and for hay, but its chief value is for soiling, for which purpose it may be cut two or three times during the season. The plant is biennial in duration, growing about two feet high the first year and attaining its full growth of about four feet the second. Sown in the South generally in the fall, but can be sown either fall or spring. Fifteen pounds to the acre. By mail, post-paid, $50 \mathrm{c}$. per 1b.; by express or freight, per lb., 35c.; I5 lbs., \$3.75; 50 lbs., \$11.00; 100 lbs., \$20.00.

California Bur Clover (Medicago denticulata).-Valuable for winter pasture in the South. All stock eat it freely when they have acquired a taste for it, asd the burs left on the ground provide food for hogs and sheep. Succeeds much better than red lover on the eocene formation, and is besides much superior clover on the eocene formation, and is besides much superior Sow at the rate of ten pounds to the acre. By mail Sow at the rate of ten pounds to the acre. By mail,
post-paid, 40c. per lb.; by express or freight, Io 1bs., $\$ 3.00 ; 50$ lbs., \$1 2.co. 


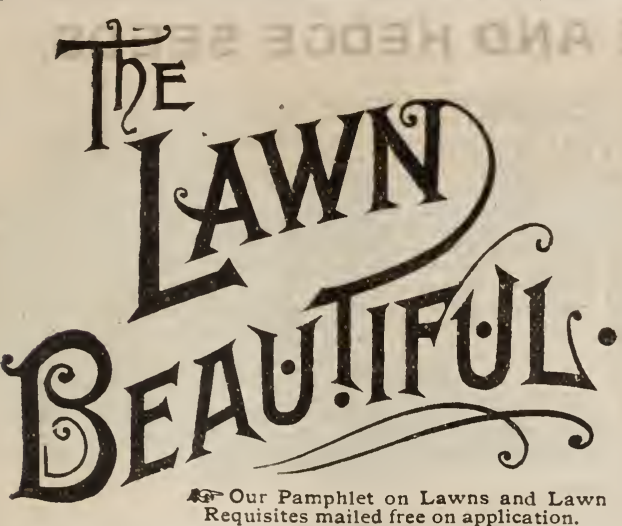

No. 28. Gardiner's "Popular" Evergreen Lawn Grass Mixture.

This mixture is designed specially for those with large estates, and for public parks and cemeteries, where a good lawn is wanted at a moderate figure. Some of the more expensive sorts are reduced or left out, in order to bring the price down to a very low limit. This mixture is also over the standard weight of $14 \mathrm{lbs}$., but is sold by weight $-i$. e., $14 \mathrm{lbs}$. per bushel.

TABLE SHOWING THE PROPORTIONS OF THE DIFFERENT GRASSES WHICH COMPRISE OLR SPECIAL MIXTURE No. $2 S$

Kentucky Blue Grass (Poa pratensis)

Rhode Island Bent (Agrostis canina)

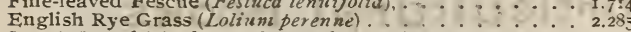

Sweet Vernal (Anthoxanthum odoratum)

White Clover (Trifolium repens),

Total per acre- $-3^{1 / 2}$ bushels of $141 \mathrm{bs}$.

Price, in lots of $I$ acre and under, $\$ 2.75$ per bushel, $75 c$ per pe 2oc. per qt. Mailing, $5 c$. per qt.
Price, in lots of 1 to 5 acres, . . . . \$2.61 per bush. 5 to ro acres, 2.47 2.34
GARDINER'S "SPECIAL" MIXTURES FOR-

\section{PERmanent EVERGReen Lawns.}

To produce a fine lawn from seed, those varieties of grasses that are evergreen in their nature should be used, and all those that have a rank habit like Timothy, or a tufty growth like O: chard Grass, should be avoided. A tolerable sward can be made by simply sowing Red Top or Blue Grass, and where price is au object, or where large spaces are to be covered that are $110 t$ particularly prominent, these may be used with perhaps the addition of a pound of White Clover to every bushel, but to make a really beautiful velvety lawis, the addition of the fine-leaved. deep green sorts, such as Sweet Vernal, Fine-leaved Fescue, etc. is imperatively necessary, and in a croquet or tennis ground where there is a great deal of tran pling, the hardy and persistent Crested Dog's-tail and Hard Fescue are indispensable.

No. 27. Gardiner's "Special" Evergreen Lawn Grass Mixture.

This is the very finest mixture that can be made, and should aiway's be used where a very fine lawn is wanted. It is good for croquet greens, tennis grounds, etc., and is recommended above all others, where the very best effect is desired. The seed is extra clean and extra heavy, and will weigh per bushel much
over the standard weight of $14 \mathrm{lbs}$. But we quote per bushel of over the standard weight of I4 lbs. But we quote per bushel of
I4 lbs. in order to avoid confusion, and although the bulk is less the proportion of good seed is nuch larger than in ordinary samples. We sell by weight-I4 lbs. per bushel-not by the measured bushel.

TABLE SHOW"ING THE PROPORTIONS OF THE DIFFERENT GRASSES WHICH COMPRISE OUR SPECIAL MIIXTURE NO. 27

Kentucky Blue Grass (Poa pratensis), .

Rhode Island Bent (Agrostis canina)

Fine-leaved Fescue (Festuca tenuifolia).

Hard Fescue (Festuca duriuscula).

Crested Dog's-tail (Cynosurus cristatus).

Sweet Vernal (Anthoxanthum odoratum)

Rough Stalked Mleadow (Poa trivialis),

White Clover (Trifolium repens),

Sow $3^{1 / 2}$ bushels per acre.

2.857
2.35 2.357
1.74 1.714 1.143 $.5-1$ 35 I.143 14.000

Price, in lots of $\mathrm{I}$ acre and under, $\$ 3.50$ per bushel, $\$$ r.00 per peck 20c. per qt.

Price, in lots of I to 5 acres, . . . . \$3.33 per bushel. 5 " 10 "

Note.--This mixture we guarantee to be as fine as any advertised Note.--This mixtule we guarante
at funcy prices. Mailing 5c. per qt.

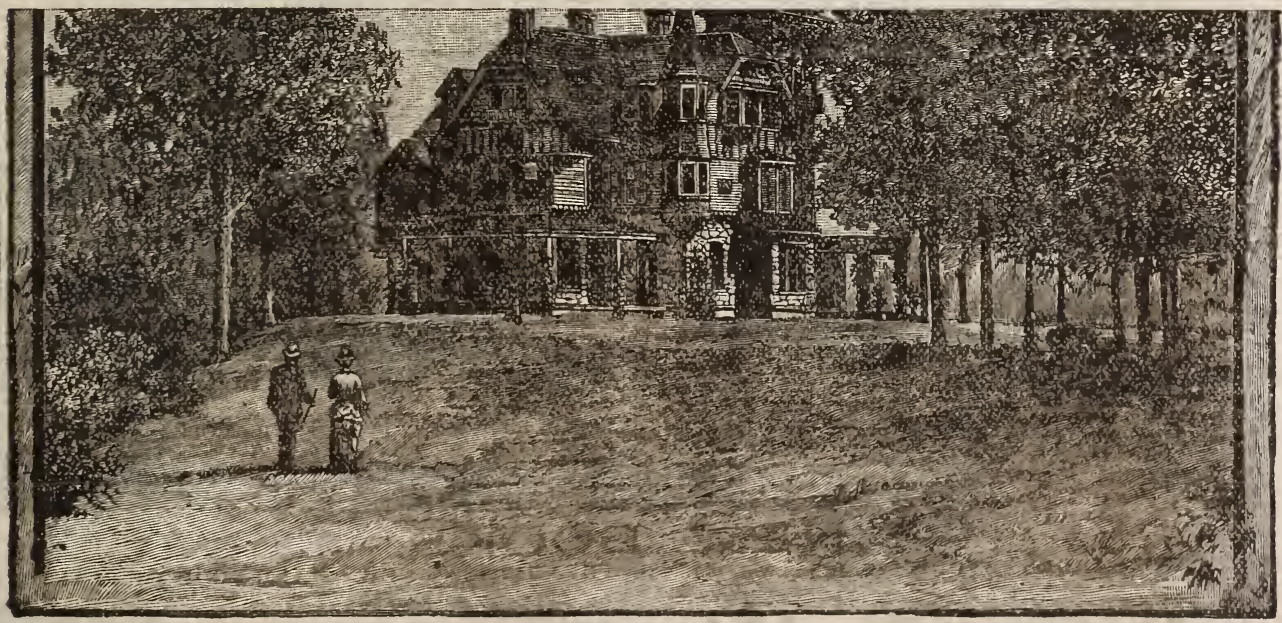

GARDINER'S "SPEOIAI" IA WN FERTILIZER.

This special preparation contains all the constituents necessary for the vigorous production of luxuriant verdure of a rich velvety-green ; it is prepared in the form of a dry powder and is almost odorless, so that the most fastidious person can handle it with ease and comfort, and it is also marrellously quick in action, the increased thickening and deeper green of the sward being very apparent soon after its application. For all kinds of lawns, whether large or swall, this dressing is undoubtedly the cleauest. earies! to apply, most econonical, convenient, and powerful. Its use by the most proninent gardeners all over the coututry being ample testimony of its iutrinsic value. Put up iu 10, 25, 50 and 100 pound bags. Apply at the rate of 400 pou uds per acre.
1o pound bag (sufficient for $20 \mathrm{x}$ 50 feet of lawn, ). . .
25
$25 \times$ Ino
$\$ 0.5 \circ$
50
1. acre of lawu.
3.75 


\section{TREE, SHRUB, VINE AND HEDGE SEEDS.}

Balsam Fir (Abies balsamea),

Pkt. Oz. Lb.

Hemlock Spruce (Abies canadensis), ....... I5 $50{ }_{50}^{500}$

Douglas Fir (Abies Dougıassi), ${ }^{\circ}$, per hundred
Norway Spruce (Abies excelsa), per

Norway Spruce

pounds, \$70.00,

Norway Maple (Acer platanoides)

Sycamore Maple (Acer pseudo-platanus),

Sugar Maple (Acer saccharinum)

Dutchman's Pipe (Aristolochia sipho),

Barberry (Berberis vulgaris),

White Birch $B$ tula alba)

Weeping Birch (Betula pendula),

Allspice or Strawberry Tree

Floridus). Strawbery Tree (Caljicanthis

Shellbark (Carya àlha), per quart 60 cents.

Catalpa Speciosa (Hardy catalpa)

Cladrastis Tinctoria ( Yelllow wood),

Dogwood (Cornus Florida),

Lawson's Cypress (Cupressus Lawsoniana)

Blue Gum (Eucalyptus globosus),

White Ash (Fraxinus alba)

Scotch Broom (Genista scoparia).

Honey Locust (Gleditschia triacanthos), per

hundred pounds, $\varepsilon_{35.00}$,

Silver Bell or Snowdrop Tree (Halesia tetraptera),

English Ivy (Hedera helix),

Holly (Ilex opaca).

Butternut (Juglans cinerea), 40 cents per quart.

Black Walnut (Juglans nigra), 40 cents per quart.

Red Cedar (Juniperus Virginiana),

Juniper (Juniperus communis), .

European Larch (Larix Europica)

Privet (Ligustrum vulgare)

Tulip Tree (Liriodendron tulipifera)

Osage Orange (Maclura aurantiaca), per hun-

dred pounds, $\$ 35.00$,

\section{Agriealtaral}

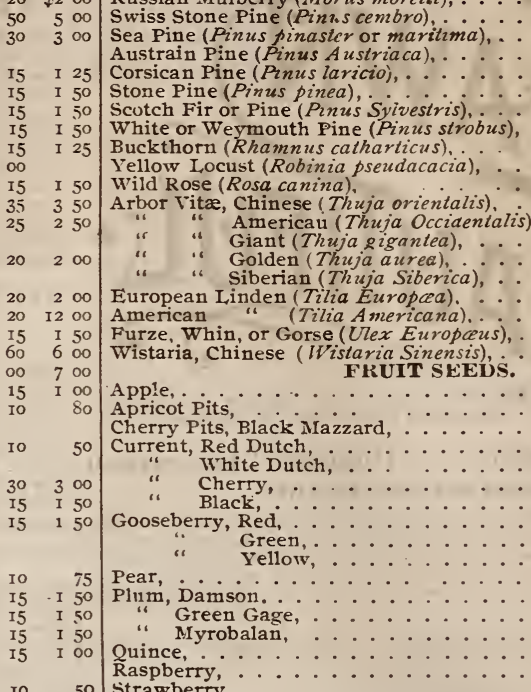

50 Strawberry,
Pkt. Oz. Lb. Ioc. \$o $30 \quad \$ 300$ $\begin{array}{lll}5 & \text { I } & \text { I } 00 \\ 5 & \text { I } & \text { I } 00\end{array}$ $\begin{array}{rrr}5 & \text { I5 } & \text { I } 50 \\ \text { I } & 30 & 300\end{array}$ $\begin{array}{rll}\text { In } & 30 & 300 \\ 5 & 15 & 100\end{array}$

Horticaltural Books.

The undernoted are standard and reliable works on horticulture and agriculture, and, as we have made special arrangements with the publishers, we give our customers the benefit of the reduced prices. We maii free. to any address, at the cash prices annexed.

\section{THE GARDEN. Pub- $\quad$ lishers' Cash \\ Prices. Price.}

Play and Profit in My Garden ... Rev, F. P. Roe, .\$2 $00 \$ 180$ Gardening for Profit (new edition), Henderson, Gardening for Pleasure/mew edition)Henderson, Ornamental Gardening,........ A. Long, Money in the Garden, . . . Quinn, . . Practical Floriculture (new edition), Henderson,... I 50 Parsons on the Rose, . . . . Sam'1B. Parsons, I 50 Your Plants, and How to Grow Them, Sheehan, .... 40

Lilies, and Their Culture, . . . Dr. Wallace, . I 65 Success in Market Gardening, . W. W. Rawson, I 00 Garden and Farm Topics,..... Henderson,... I 50

\section{FOREST.}

Fuller's Practical Forestry, . . . . S. Fuller, . . . I 50 The Forester, ... James Brown, ... I0 00

\section{FRUIT.}

Field Notes on A pple Culture, . - L. H. Bailey, Jr., 75 Barry's Fruit Garden, ...... Barry, W. Strong, . . 200 Fruit Culture,

Grape Growers' Guide,

Fruit and Fruit Trees of America, Chorlton,... 75

Small Fruit Culturist, .............. Fuller, 50

Grape Culturist, . . . . . Fuller, . . . . I 50

Peach Culture, . . . . . . Fulton, ..... I 50

Pear Culture, ......... Quinn, .... I 0

Cranberry Culture, . . . . White, . . . I 25

Small firuits,

NEIN

"THE GARDEN'S STORY."-G. H. ELLWANGER.

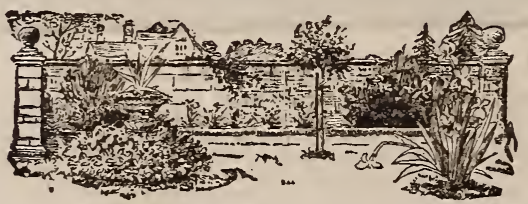

A delightful new book; a rare treat for all lovers of a beautiful garden. $35^{6}$ pages, gilt, published at $\$$ I.50; our price, $\$$ I. $3^{8}$, free Allen's New America: Farm Book, Rich'd L.Allen, . \$2 $50 \$ 2 \quad 25$ 80 Farming for Profit,......... John E. Read, . 375338 80 French's Farm Drainage,...... Judge French, . I 50 I 35

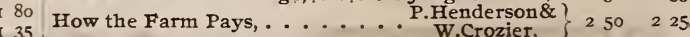
35 Facts for Farmers, I, Ioo pages, .. Solon Robinson, 500450 70 Silos and Ensilage,......... George Thurber, 5045

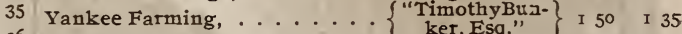
36 Farm Implements and Machinery, Thomas, ... I so I 35 I 48 Book of the Farm, . . . . W. Waring, ... 2 o0 I 80 90 American Cattle,................. 250225 35 The Pig, ............... I 50 Harris, . 35 Youatt on sheep,......... Ymouatt, . I oo American Dairying, .......... I 50 I 35 I 35

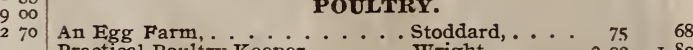
Practical Poultry Keeper, .... Wright,... 200 I 80 Profitable Poultry Keeping, . . . . Stephen Bisbe, . I 50 I 35

\section{MISCELLANEOUS.}

90 Elements of Scientific Agriculture, Norton, . . . . 7568 68 Injurious Insects of the Farm and $\}$ Treat,..... 200 I 80 45 Garden,................. 200 Treat,... 180 35 Canary Birds, . . . . . . . Holden of Birds, 75

35 Rural Architecture, . . . . I 50 I 35 90 Graperies and Horticulturai Build- $\{$ woodward, . . . I 0090 90 Quinby's New Bee Keeping, . . . . . . . . . I 50 I 35

\section{HENDERSON'S NET “HAND-BOOK OF PLANTS."}

Revised and enlarged as this valuable publication now is, it is undoubtedly the most practical and complete work of its kind in this country, and should be in the hands of all arua.eurs and young florists and gardeners. It is a bulky volume of over 500 pages and is profusely illustrated. Price, $\$ 4.00$, free by mail.

\section{SENSIBLE LOW COST HOUSES.}

This contains plans, illustrations and complete descriptions of $56 \mathrm{New}$, Beautiful and Cheap Country Houses, costing from $\$ 800$ to $\$ 7.500$. Shows how you can build a $\$ 2,000$ huuse for $\$ 1,750$, and how to make them handsome, convenient, healthy, light, cool and airy in summer, warm and cheaply heated in winter. Price, $\$ 1$ oo by mail; given free with an order for $\$ 5.00$ from this catalogue. 


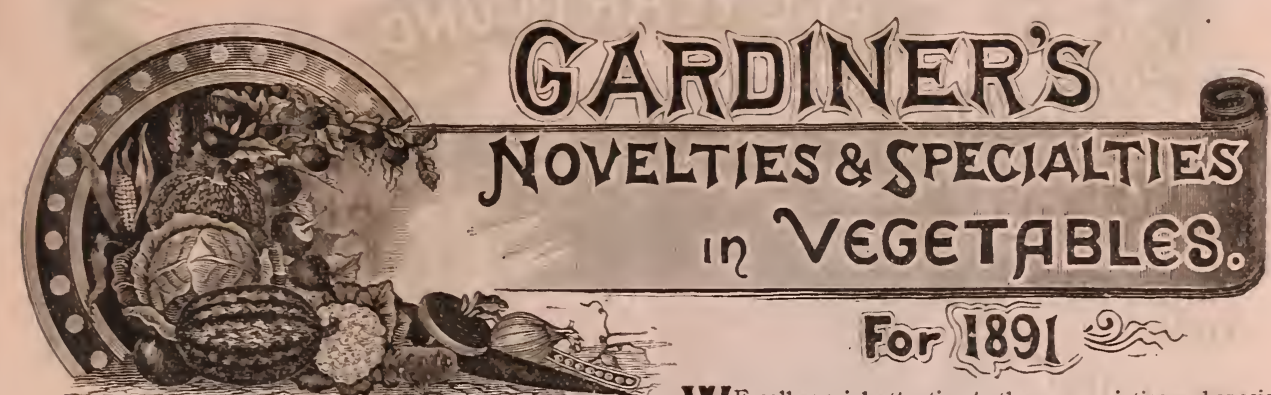

WVE call special attention to the new varieties and special strains offered in the following list. Many of them are norelties of great promise, which are catalogued now for the first time, and cannot fail to prove very interesting to all enthusiastic gardeners. We allow no new variety into our list unless it emanates from our own establishment, or from some other house of reliability and standing, in whom we repose the utmost confidence. The stocks we offer in specialties are nearly all of them grown exclusirely for our special retail trade, and are therefore not to be obtained, of such superior excellence, from any other source whatever.

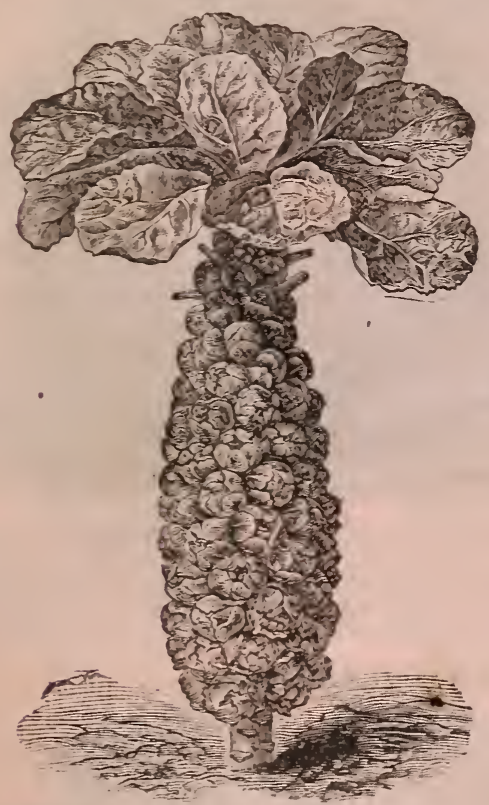

The Craigo Brtssels Sprotts.

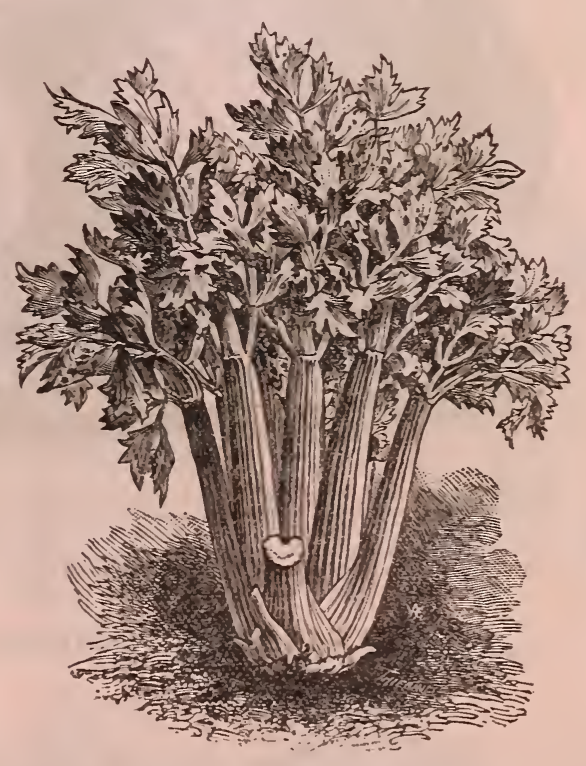

Giant Pascal Celer:.

\section{THE CRAIGO BRUSSELS SPROUTS.}

This is probably the finest strain of Brussels Sprouts in cultivation. It is very early, of dwarf, robust growth and covered the entire length of the stem with compact sprouts of rery superior flavor. The sprouts are exceedingly hard-heading and cook tender and delicious; unequalled for delicate table quality. Our seeds are grown from the stock of the original raiser and are true and very select. All who would have this splendid vegetable in perfection should try this strain. Brussels Sprouts may be cultivated in the same way as cabbage. The crop will be ready for use after the first frost in October. Cooked the ric same as cauliflower it is one of the finest regetables that can be
put on the table, being very tender and delicate. Pkt. Ioc., 3 pkts. $25 \mathrm{C}$.

\section{GIANT PASCAL CELERY.}

A magnificent new celery, one of the best norelties, and one that will find universal favor as soon as known. It possesses all the good qualities of the excellent and popular Golden SelfBlanching, from which it is a sport. The stalks are very large, solid and crisp; the flavor is rich and nutty, and free from any trace of bitterness. Blanches readily and quickly and retains its freshness a long time after being marketed. It grows somewhat larger than Golden Self-Blanching, with very wide and thick stalks, the outer stalks being light green, the inner a deep rich golden-yellow. In size, handsome appearance and superior keeping qualities unsurpassed. One of the finest varieties for winter use, probably the very best in cultivation in this respect. Pkt. Ioc., 3 pkts. 25c., Oz. 75 c. 


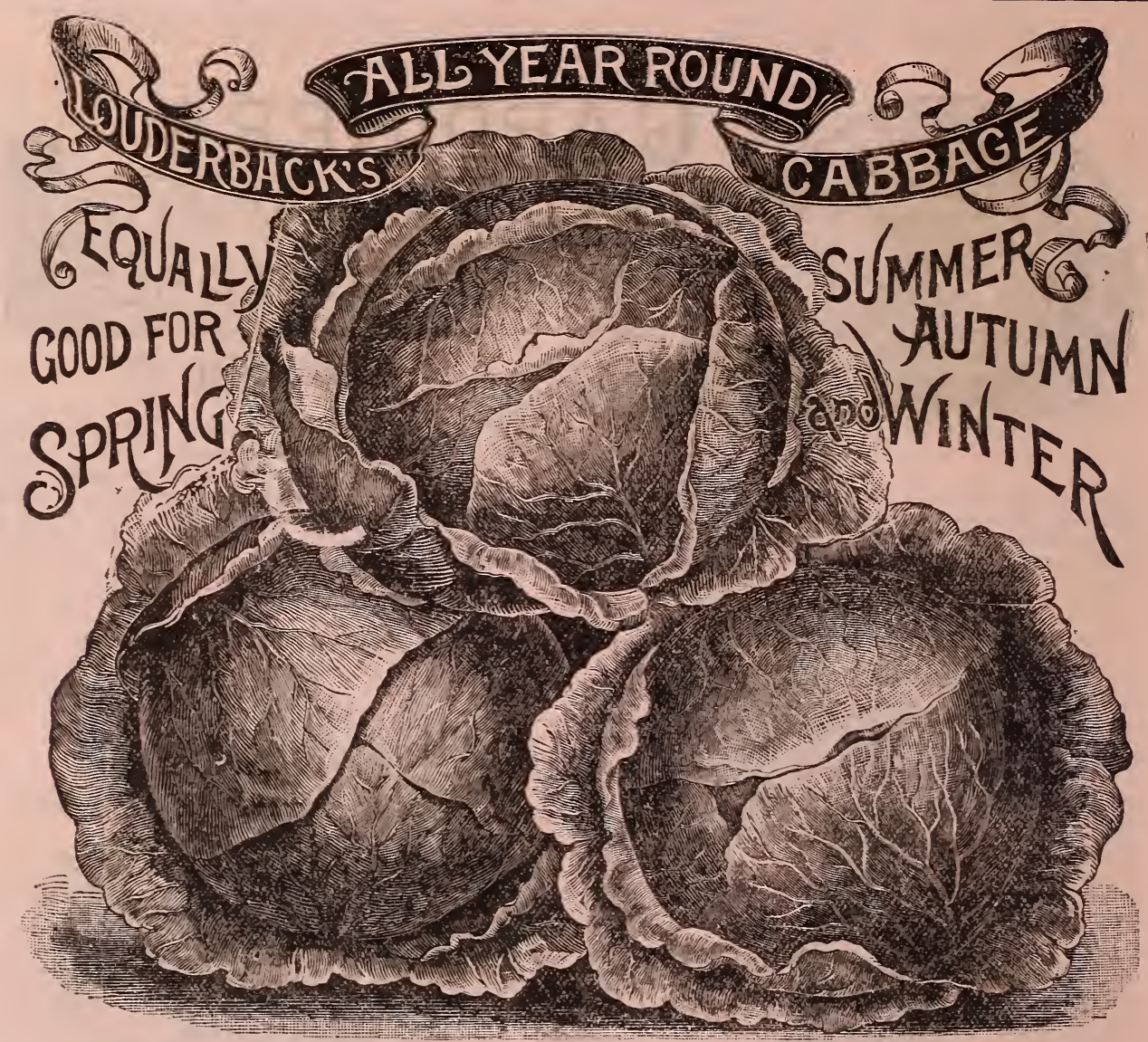

This cabbage originate I with Daniel Louderback, one of the oldest and most successful of Philadelphia market gardeners, and has had a great local re putation = "1ong his neighbors for several years. It is not only the finest Early Drumhead in cultivation, but is equally as good for second cnd third early, intermediate and late. It heads large and solid, with very short stem and few outer leaves, unflagoing under the hottest sun or heaviest frosts and may be sown successively and continuously during all periods when cabbage is planted. As an all-round cabbage nothing we have ever seen approaches it. The seed we offer was grown by Daniel Loucerhack, the originator. We recommend it to all who desire something very choice. Pkt. I5c., oz. 50c., $1 \mathrm{~b}$. \$5.00.

CUCUMBER, THORBURN'S NEW EVERBEARING.

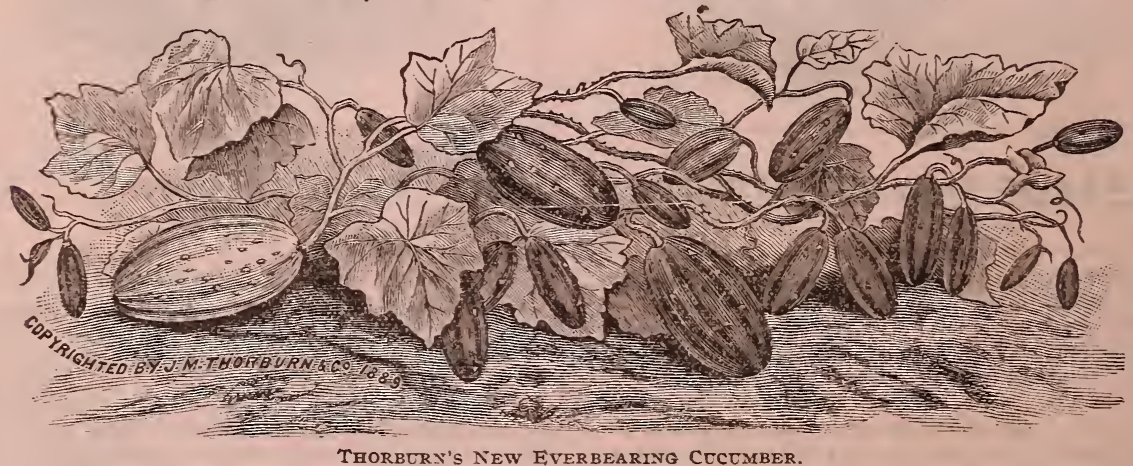

We call special attention to this entirely new and unique variety. It is of small size, very early, enormously productive, and valuable as a green pickler. The peculiar merit of this novelty is that the vines continue to flower and produce fruit until killed by frost, whether the ripe cucumbers are picked off or not-in which respect it differs from all other sorts in cultivation. Cucum. bers in every stage of growth will be found on the same vine. Pkt. IOc., 3 pkts. $25 \mathrm{c}$. 


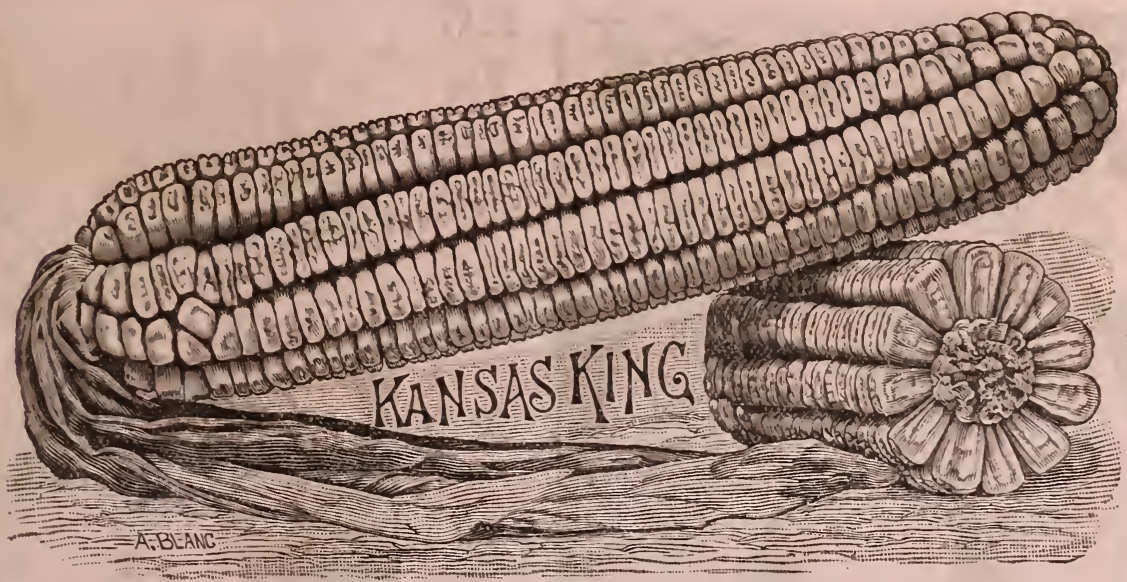

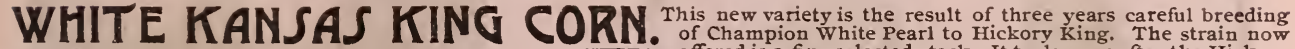

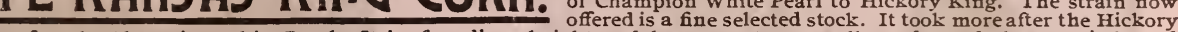
King than after the Champion White Pearl. It is of medium height and has very strong stalks and stands heavy winds and storms without being blown down. The ears are set on heavy stems, are borne generally two ears to the stalk, and sometimes as many as four to the stalk. The grains are long, shaped like Champion White Pearl and the cob is small like Hickory King. The ears weigh heavy, averaging nearly one pound each and have from ro to I4 rows. This corn husks very easily. Notwithstanding the extreme drouth and hot winds prevailing in Kansas last season, 50 bushels per acre of this variety were harvested in some instances. Pkt. IOc., 3 pkts. $25 \mathrm{c}$.

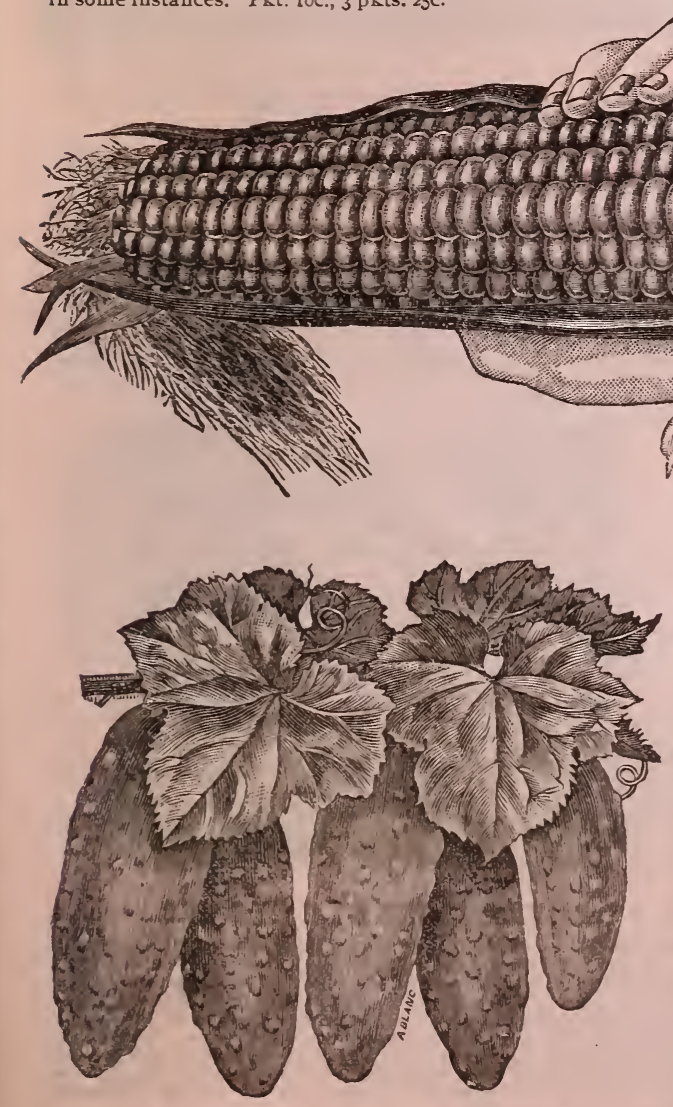

Westerfield's Chicsgo Pickling CUCUMBer.

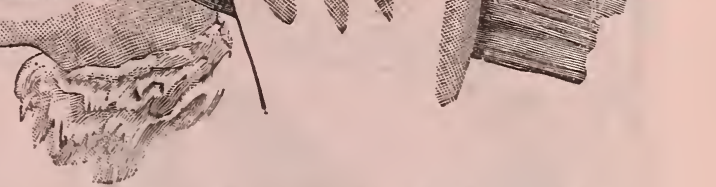

\section{NEW : RED : COB : EVERGREEN SWEET : CORN.}

This raluable new variety "Red Cob Evercreen," is a sport from the "Stowell's," which has cob been the standard and favorite in all parts of the country. This new variety is destined to eclipse in popularity its famous parent, it being a week to ten days earlier and is enormously productive, bearing three to four ears to a stalk. The ears are set low on the stalks and are very thick and regular in size-r6-rowed-very deep and of the most delicious quality, remaining tender and milky for a long time. This variety is very distinct when in the dry state, both kernels and cob being of a deep red color. Pkt. 15c., 8 phts. $\$$ r.00.

\section{^ CHICAGO • PICKLE - CUCUMBER. ^}

This now celebrated strain of pickling cucumber is the result of a long process of special selection and culture by a large grower for the Chicago market (Mr. Westerfield). The fruits, as shown in the engraving, are short, straight and of a fine deep green and are crisp and tender in quality. The vine is an green and are crisp and tender in quality. The vine is an ness. For pickling purceder be ins fine appearance are desired be highly recommended. The seeds we offer are the true Westerfield strain, grown from the raiser's stock. Pkt. 5c., oz. Ioc., lb. \$r.oo. 

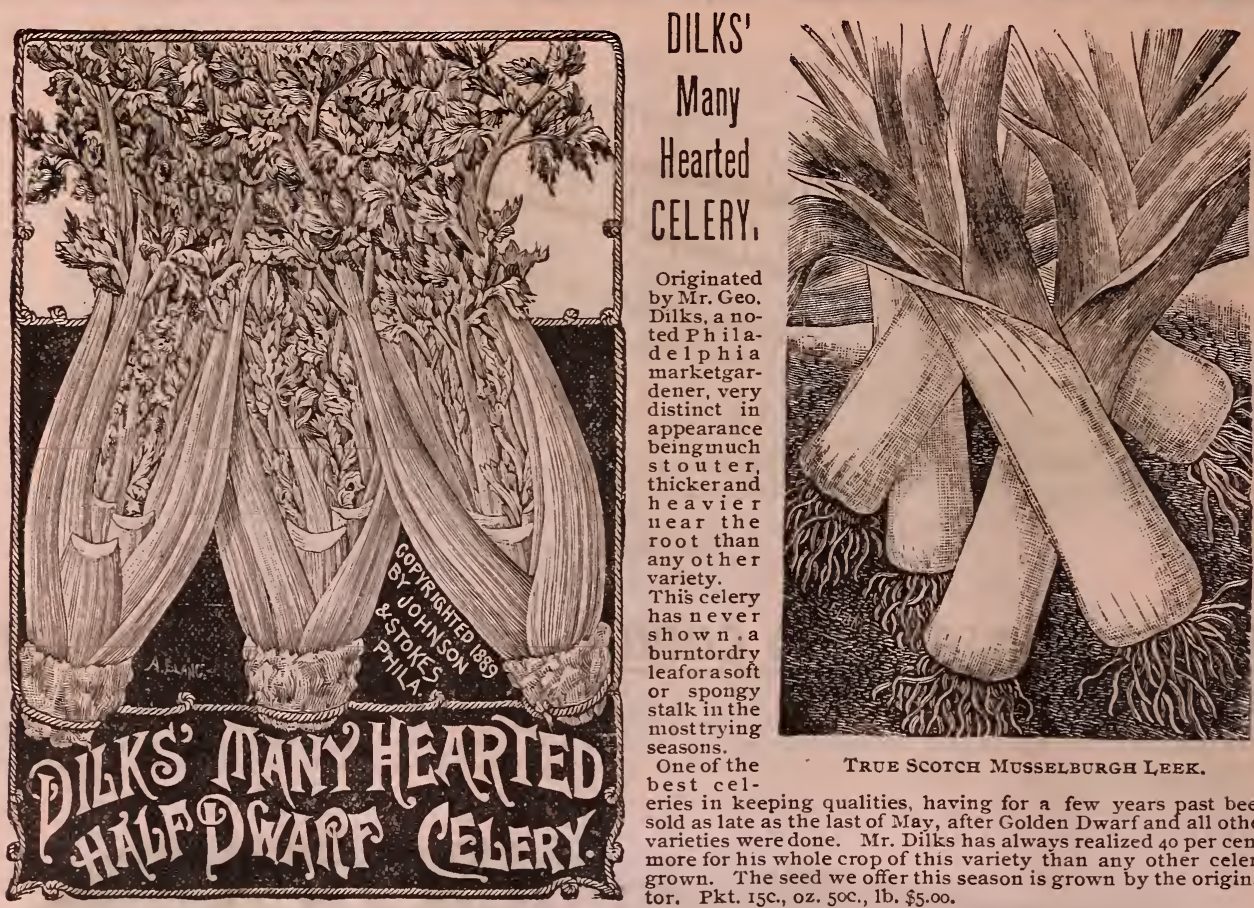

One of the

best cel-

TrUe SCOTCh MUSSELbURGh Leek.

eries in keeping qualities, having for a few years past been sold as late as the last of May, after Golden Dwarf and all other varieties were done. Mr. Dilks has always realized 40 per cent. more for his whole crop of this variety than any other celery grown. The seed we offer this season is grown by the origina-

^ FARIS PICKLING CUCUMBER. ^

This distinct and remarkable variety is possessed of rare merit as a pickling sort. The fruits are of a fine deep green color and in the pickle stage are slender, 3 to $5 \mathrm{ins.} \mathrm{in} \mathrm{length,}$ and covered with delicate black spines as shown in the en-
graving. Their remarkable value lies in their crispness and

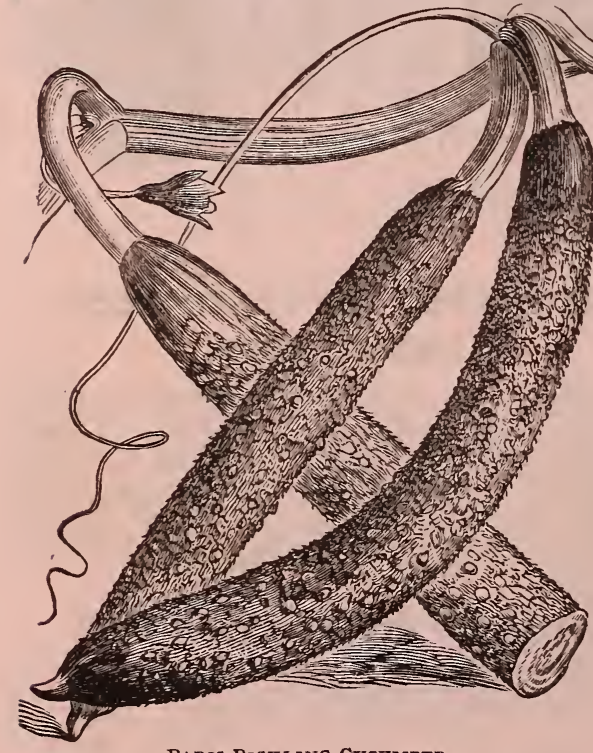

Paris Pickling CUCUMber.

fine quality. They are absolutely unsur passed in this respect, snapping as easily as the best snap-beans and showing no seeds. These distinctive features (brittle and seedless fruits) insure the greatest popularity for this variety as soon as it
becomes known. Pkt. Ioc., 3 pkts. 25 c.
TRUE \& SCOTCH : MUSSELBUR GH \& LEEK. The great superiority of this strain of leek in size, rapidity of growth and fine quality has been amply demonstrated. We have imported our seed direct from Scotland at a high figure, and can recommend it as being true and extra select. The stem in this fine sort seldom exceeds 6 or 8 inches in length, but it is often 2 inches or more in diameter in well-grown plants. and we have frequently seen it on exhibition very much larger, both in length and diameter than this. It is exceedingly hardy and the leaves are of a fine deep green much darker than the large French leeks and the blanched stem is also of superior mild flavor to any other sort we have ever seen. Undoubtedly the best leek grown on account of its large size, hardiness and rich, mild flavor. Dkt. Ioc., oz. $50 \mathrm{cc}$.

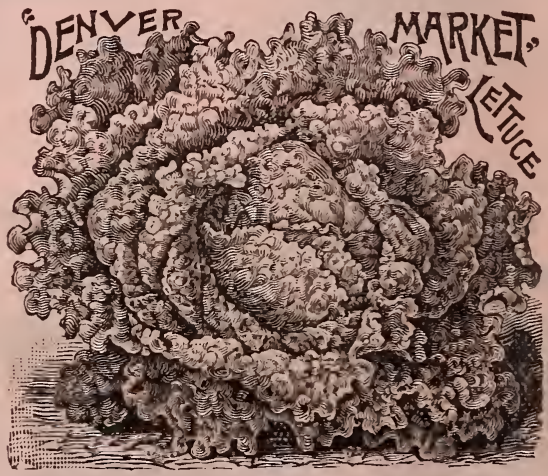

^ $\Delta$ A DENVER MARKET LETTUCE. $\Delta$ ^

This fine lettuce originated with a prominent market gardener of Denver, Col, and competent authorities declare it to be the finest novelty since the introduction of the Black-Seeded Simpson. The heads are large, solid, light green, beautifully curled like a Savoy cabbage, very crisp and tender. The crimpled leaves are a distinct feature, distinguishing it at a glance from other sorts. The heads are a little after the style of the Hanson but more oblong. In delicate and tender table qualities it is very superior, being free from any trace of bitterness. Good either for forcing or outside planting. Pkt. Ioc., 3 pkts. 25 c. 


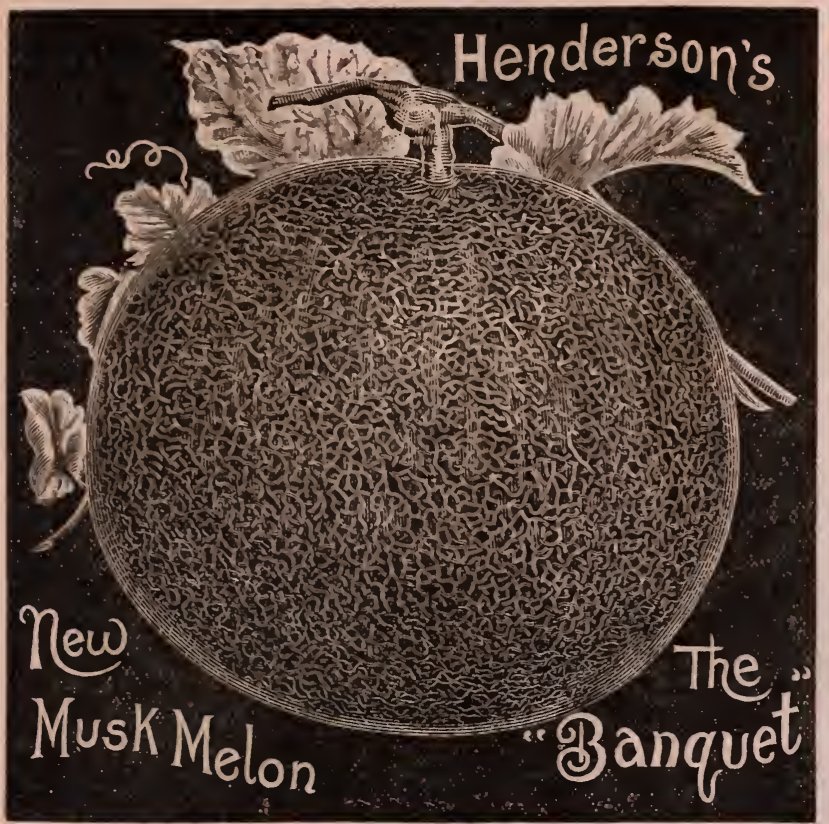

\section{NEW MUSKMELON.}

\section{"THE BANQUET."}

The most luscious and beau-

tiful melon in existence.

This superb melon represents years of careful selection and improvement of a stock of Muskmelons, at the hands of the largest and most experienced grower of melons in the world. The raiser regards it as his greatest production, and likely to supersede all other red-fleshed varieties. The cut shown is an actual reproduction of a photograph. "The Banquet "is a medium-sized melon, very flat at both ends and more beautifully netted than any known variety. In quality it has no equal; the fiesh is uniformly deep and of that granulate character that always indicates a good melon; color dark rich salmon. The oftrepeated question, "How can I raise good Muskmelons?" can now be answered. "Plant the Banquet." We are safe in saying that it will produce more fine edible melons to a given area than any other variety. Pkt. 25c., 5 pkts. $\$ 1.00$.

\section{Winter Pineapple Muskmelon.}

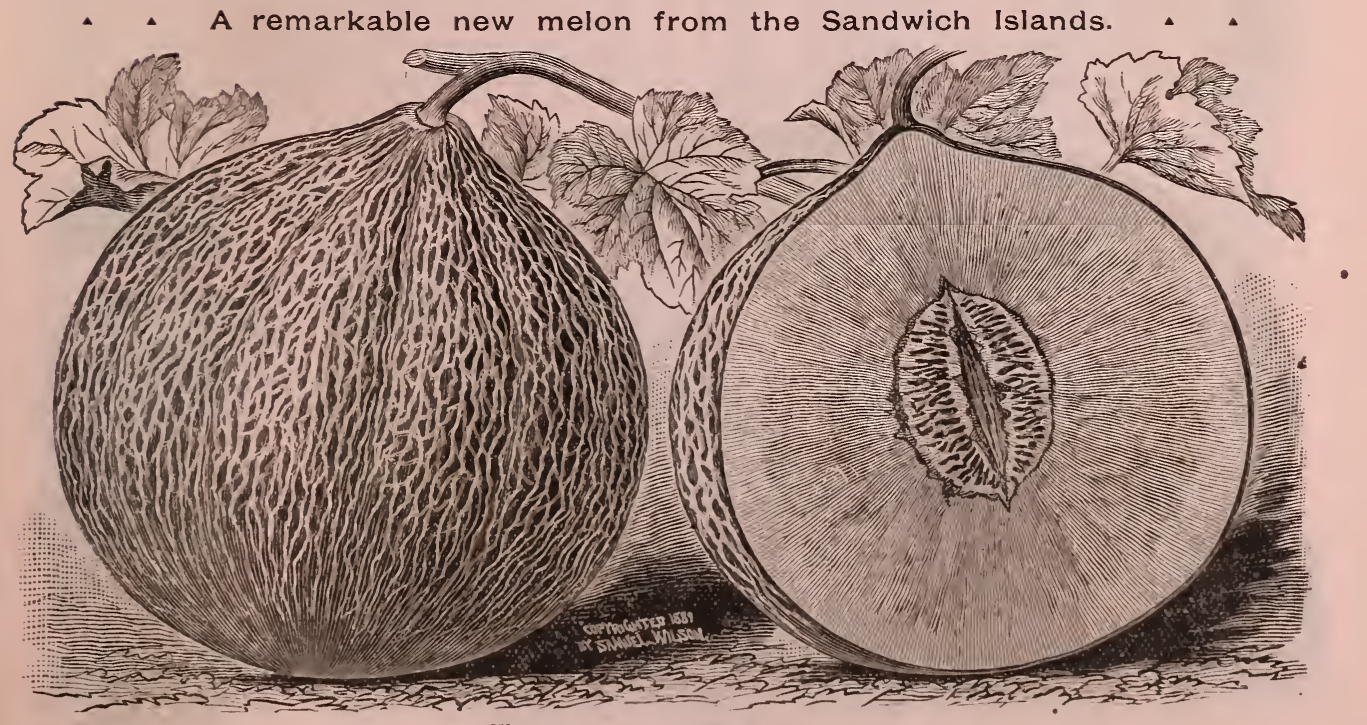

\section{Winter PiNeapple MUskmelon.}

The fruits do not ripen on the vines, but have to be picked in a green state, before frost, laid away in a cool, dry place, where they will keep sound and sweet for several months. When wanted for use bring them in a warm room, they will ripen in a few days and be ready to eat. They are entirely distinct from any other muskmelon ever grown in this country. When ripe the outer skin, which is deeply corrugated, is a beautiful rich golden yellow, mottled and striped with pale green. The flesh is unusually thick, solid and melting; a light green color and has the most delightful flavor imaginable, being rich, spicy and delicious, with an agreeable pineapple taste. They will remain in a good eating condition a long time after being ripened up, and even when cut retain their spicy fragrance for days. Any one by planting these melons can have the most delicious fruit all winter. Pkt. 20c., 3 pkts. $50 \mathrm{c}$. 


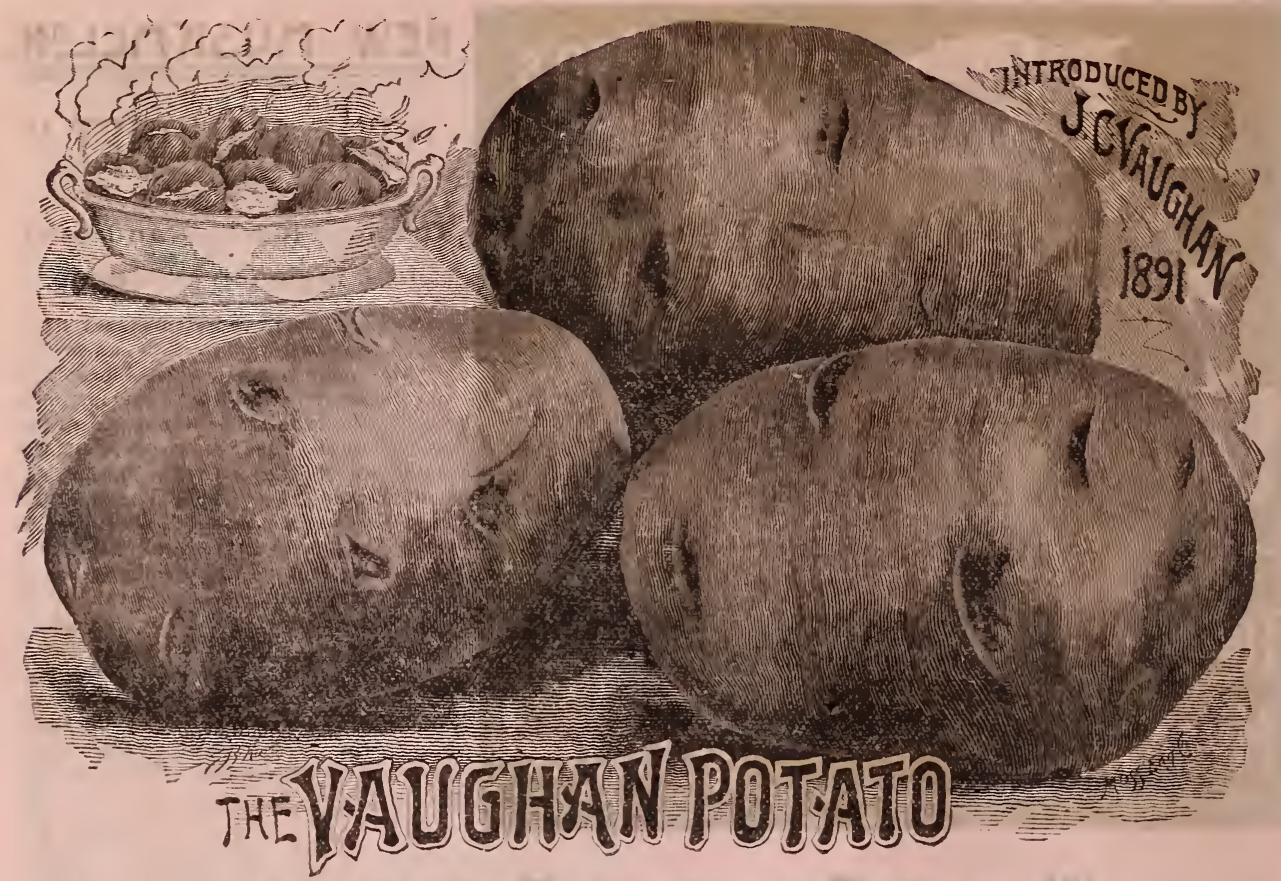

This valuable new potato was raised by Mr. E. L. Coy the originator of some of our most prized sorts. It is early, vigorous, productive and remarkably free from rot. In form somewhat like the beauty of Hebron, but longer; skin beautiful flesh color delicate and rich in flavor. From among the large number of seedlings of 1885 , Mr. Coy found after 4 years of careful trial, that this was the only one capable of standing the crucial test of open competition with pre-existing varieties, and he predicts that The Early Vaughan will occupy a prominent and enviable position as an early, both for the market grower and the private gardener. Among the 20 early sorts which he grew last season The Early Vaughan took first place in productiveness and freedom from rot -the Thorborn being its closest competitor in this regard. It ripens with the Early Puritan and like that variety is fit for table when only half-grows. L.b. 4 OC., 3 lbs. $\$$ I.00, free by mail. By express or freight, peck $\$ 1.50$ bush. $\$ 5.00$, bbl. $\$ 10.00$.

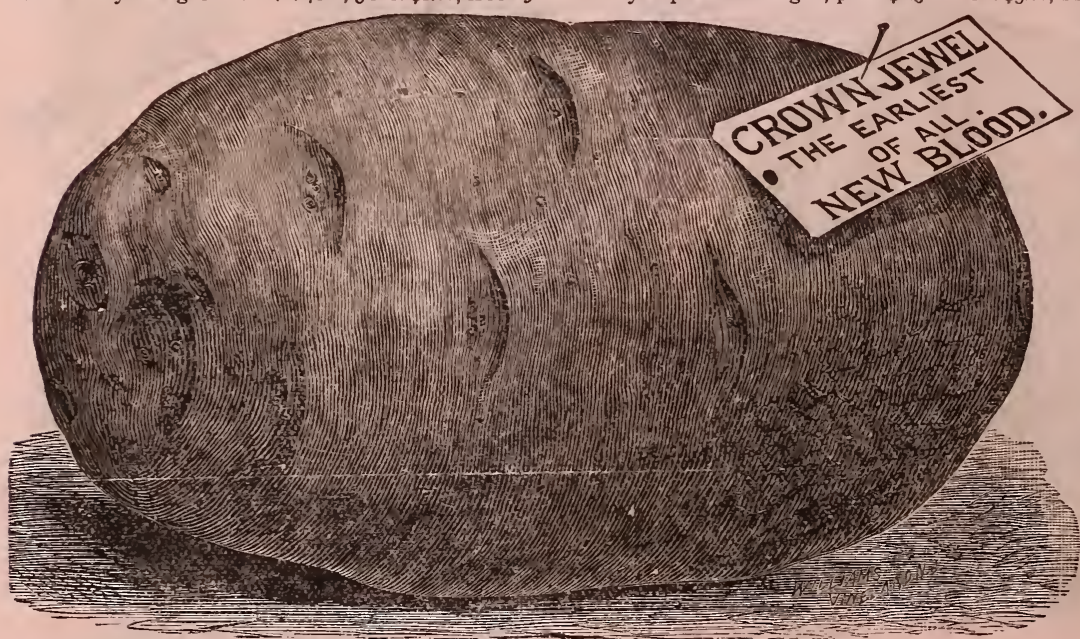

$\dot{x}$

\section{CROWN}

JEWEL POTATO.

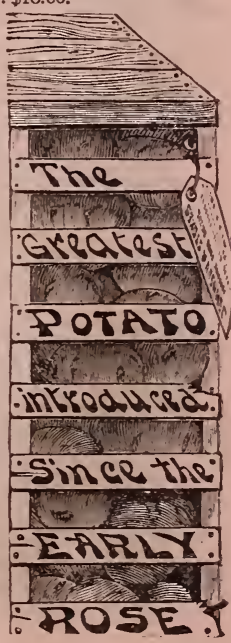

$\times \quad x$

This new variety has become exceedingly popular and has fully borne out the strong claims made for it by the introducers. It is a seedling of the Early Ohio. The seed-balls were found in a large field of that well-known variety, and it partakes of all the pure and unadulterated qualities of its excellent parent, without any admixture of baser blood. Grown in competition with the Early Ohio, Beauty of Hebron, Early Rose and Sunrise, it more than doubled the yield of any of them; under precisely the same conditions, they were ready to dig ten days earlier. The Crown Jewel is a strikingly beautiful potato, the shape is well depicted in our illustration, skin is white and smooth, eyes shallow but strong, flesh pure white and floury, cooking erenly throughout. The vines grow vigorously, the roots extend very deeply in to the soil, thus resisting drought, and its keeping qualities are equal to the best. Its extreme earliness makes it a most profitable variety for early market or home consumption. $I_{\text {, }}, 4 c c ., 31$ s. $\$$ I.00, postpaid by mail; peck goc., bush. $\$ 2.50$, bbl. $\left(2 \frac{3}{4}\right.$ bush.) $\$ 5.00$, by freight or express. 


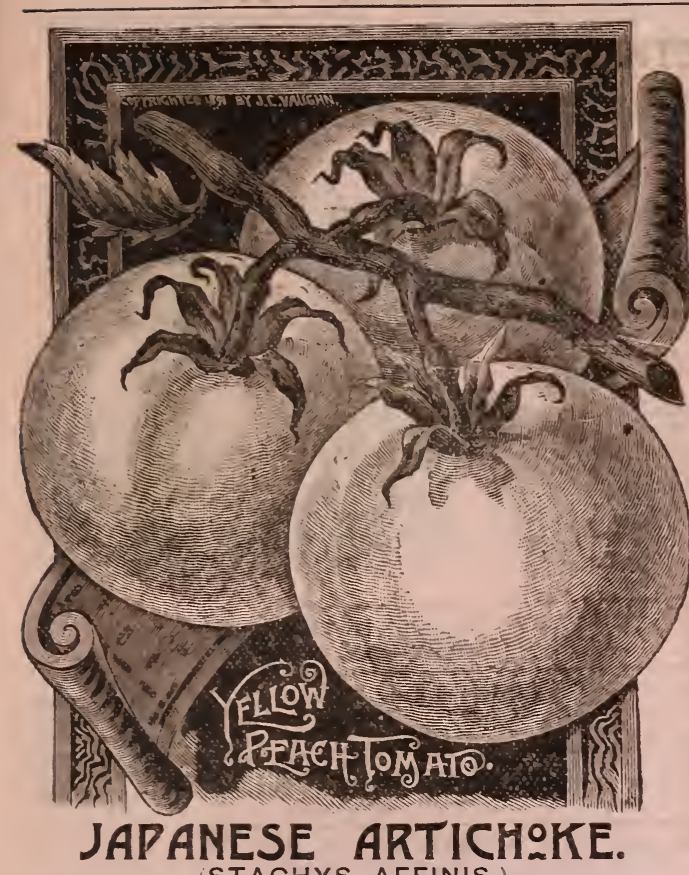

NEW YELLOW *

\section{* PEACH T:MATO.}

This fine new variety is an exact counterpart of the Peach Tomato, recently introduced, in everything except color, which is a rich golden yellow: It has the same soft, leathery skin which is such a distinctive feature of the Peach Tomato and is equally as desirable for table use, the flesh being solid, rich and unequalled in delicacy of flavor. The skin is very thin and the fruits can be readily peeled and eaten in the hand. Excellent for canning or preserves. A dish of these and the "Rosy Peach" sliced makes clle of the most ornamental dishes that can be put upon the table. Pkt. 10c., 3

\section{PEACH TOMATO.}

Those who wish to grow the New Jellow Peach should also try (if they have 110 already done so) the Rosy Peach a really fine introduction which bears fruits of a beautiful deep rose color covered with a delicate peachy bloom, making it difficult to realize that the fruits are tomatoes unless they be attached to the rines. We will send 2 pkts. Of the Rosy

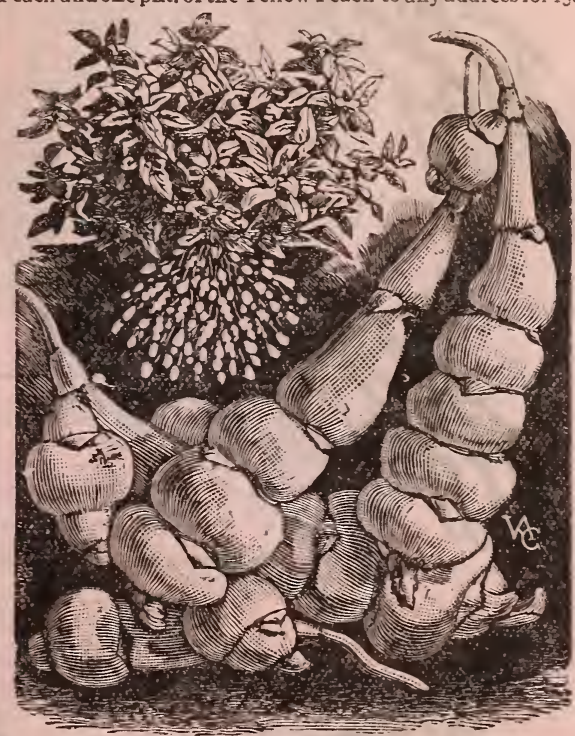

JAPANESE ARTICHOKE (Slachy's Affinis).

According to the French and German scientists this newregetable from Japan is destined to supersede our plebian potato. We tried a (n) favor. There has been so much said, however, in favor of the new vegetable by the European horticultirists since then, that we have decided to offer it to our customers and let them judge for themselves. The tubers are cultivated same as the common potato, but are perfectly hardy and may be left in the ground till spring. The tubers taste agreebly when boiled in salt and water and served with butter and parsley and they are claimed to be a fine dish prepared like pomme de terre frites (potatoes sliced small and fried in butter.) Cooked like whitebait, it is said to be a most excellent substitute for that dish. They are particularly valuable to raise for stock feeding, on account of their enormous productiveness. Like our common artichokes or parsnips, they are best left in the ground till spring. Tubers, 2oc. per doz., 75c. per $=00$.

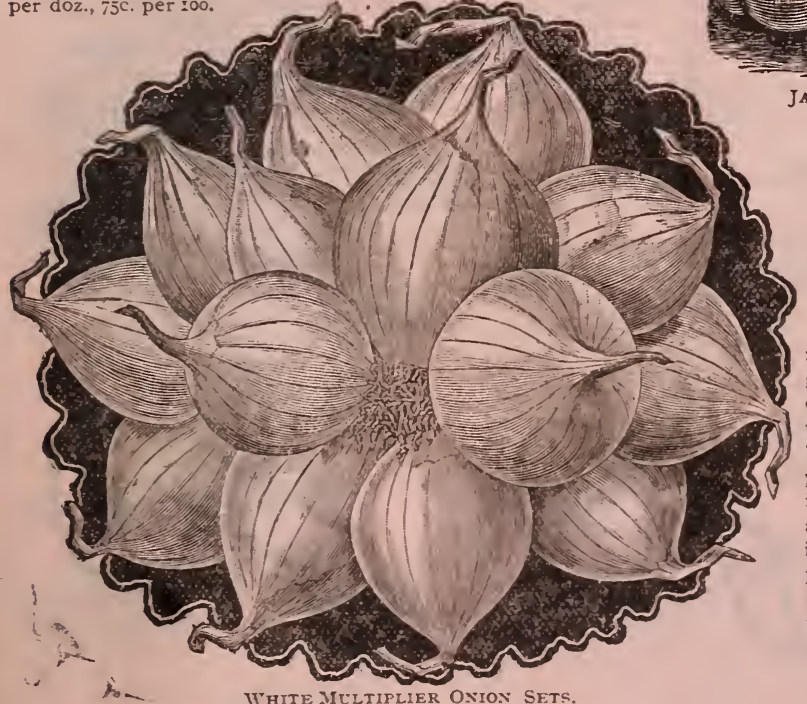

NEW WHITE

\section{MULTIPLIER ONION.}

An onion of pure white sivery coior, as shown in the cut. It is very hardy, and will prove a onion seed is usually high priced, hence the advantage of a white Mrultiplying Onion of this kind. They are the largest and best sets we know of for producing bunch onions. The largest of the sets, if allowed to grow through the summer, make an onion of fair size, which divides when ripening in the fall, multiplying liberally for anothe year. Very useful for pickling. The New White Multiplier Onion is ellormously productive, and its handsome appearance will make it one of the most salable and profitable varieties that can be grown. (See cul.) Price of sets, 35c. per pt.; 50c. 


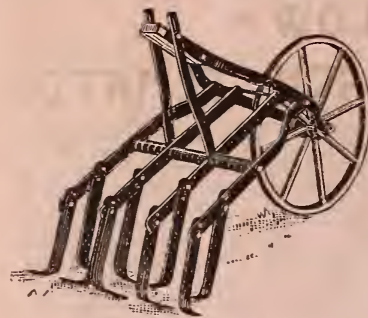

Fig. 1,-Set for 19 inches or wider.

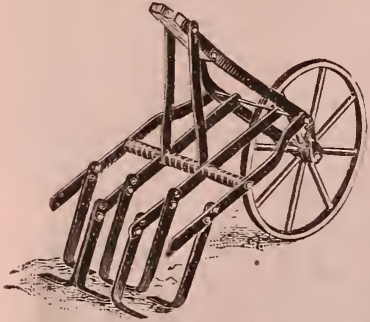

Fig. 2.-Set for 12 inches or wider.

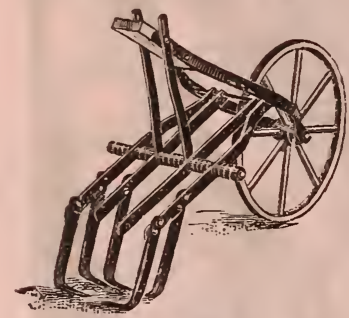

Fig. 3.-Set for 9 inches or wider.

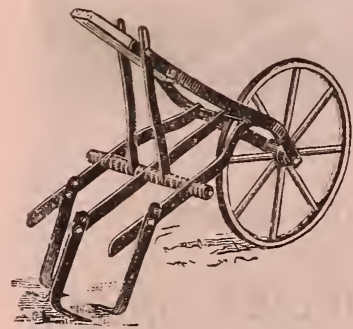

Fig. 4.-Set for 7 inches or wider.

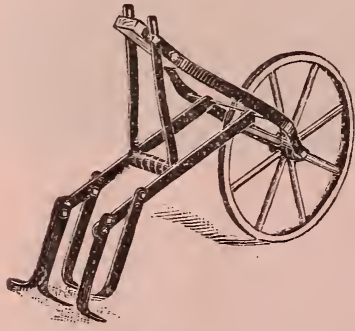

Fig. 5.-Set for 1o inches.

SOMETHING NEW.

A Wheel Hoe that will hoe a row only 5 inches zvide! The only hoe in the world that will safely hoe a row this width.

\section{$\triangle \triangle$ THE $\triangle$,}

\section{ELLIOTT • SCUFFLE WHEEL HOE}

The lightest, strongest and most effective Wheel Hoe ever offered to the public. Strong claims to make, but we feel amply justified in emphasizing them to the fullest extent. It is so light and easy to work that what is laborious by ordinary methods is niade, by the aid of this wonderful tool almost a pastime. And aithough light and easily handled, it is at the same time it is a the best high-grade tempered steel, and is practically indestructible.

\section{IT WILL SAVE ITS COST IN TEN} HOURS' WORK.

It is the only Wheel Hoe adapted to all sizes of rows. Figure 1, shows the hoe set for It is the only Wheel Hoe adapted to all sizes of rows. Figure 1, shows the hoe set for

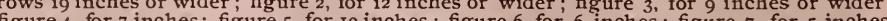
figure 4, for 7 inch; f show how almost any width can be hoed by the moving of the cutters. It is undoubtedly the best hoe for onions and all garden and bed crops, and is unequalled for killing weeds on walks and roadways.

ONE MAN CAN ACCOMPLISH AS MUCH AS FOUR WITH ORDINARY HAND OR SCUFFLE HOES.

We have room for only a few of the many indorsements of this tool by prominent market gardeners and horticulturists.

ARlington, MASS., Aug. 20, 1889

Mr. ELLIOTT-Dear Sir : I have two of your Wheel Scuffle Hoes. I have used them on hard and soft land, and find them the best tools for pulverizing the soil $I$ have ever used. They can be adjusted to any width from four to sixteen inches, so that one or two hoes will do all the work on any farm or market garden. They are very light and durable, and cause less fatigue than any hoe I have ever used. I recommend them to every one, and no market gardener should be without one. W. W. RAWSON, Market Gardener.

INSTiTuTIONS CITY FARM, LOWELL, June 25, I889.

Mr ELLrotr-My Dear Sir: After giving your Wheel Scuffe Hoe a thorough trial on Mr. Elliotr-My Dear Sir : After giving your Wheel Scuffle Hoe a thorough trial on
both light and heavy soil, we pronounce it to be far superior to any and all other inventions for garden work. One boy or man, with your hoe, can do the work of five with ease, leaving the soil in much better form. We pronounce it to be the very best garden hoe or pulverizer ever offered to the tiller of the soil. WM. A. LANG. Superintendent, Principal of Reform School. TEWKSBURY, MASs., June 6, I889.

Mr. Ephraim EllotT-Dear Sir: The Wheel Scuffe Hoe and Weeder I bought of you MR. EPHRAIM ELLIOTT-Dear Sir: The Wheel Scuffie Hoe and Weeder I bought of you has proved invaluable to me. I have never seen anything like it, and I consider it wort
much more than it has cost.

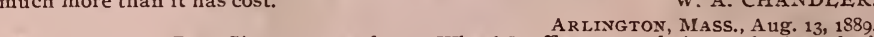
MR. ElsiotT-Dear Sir: Have used your Wheel Scuffle Hoe, and afn much pleased with it. Think it much better for loosening the soil than anything of the kind I have tried.

$$
\text { Yours truly, } \quad \text { C. A. LEARNED. }
$$

LOWELL. JUne 1I, 1889

MR. Elliotr-Dear Sir: After'using your Wheel Scuffle Hoe $\mathrm{I}$ am more than pleased. It seems to be perfection, and nothing short. I think every farmer and gardener will miss it to be without one. Yours truly, W. FRANK LAWRENCE.

PRICE \$7.00, COMPLETE.

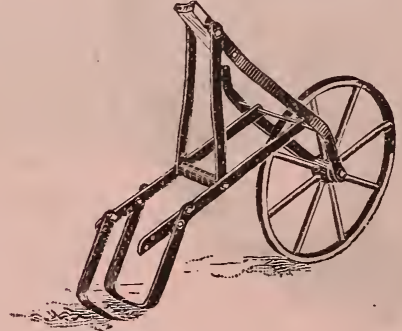

Fig. 6. - Set for 6 inches.

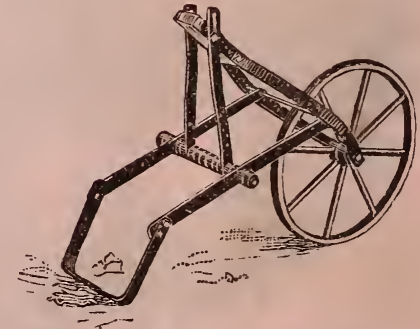

Fig. 7.-Set for 5 inches 

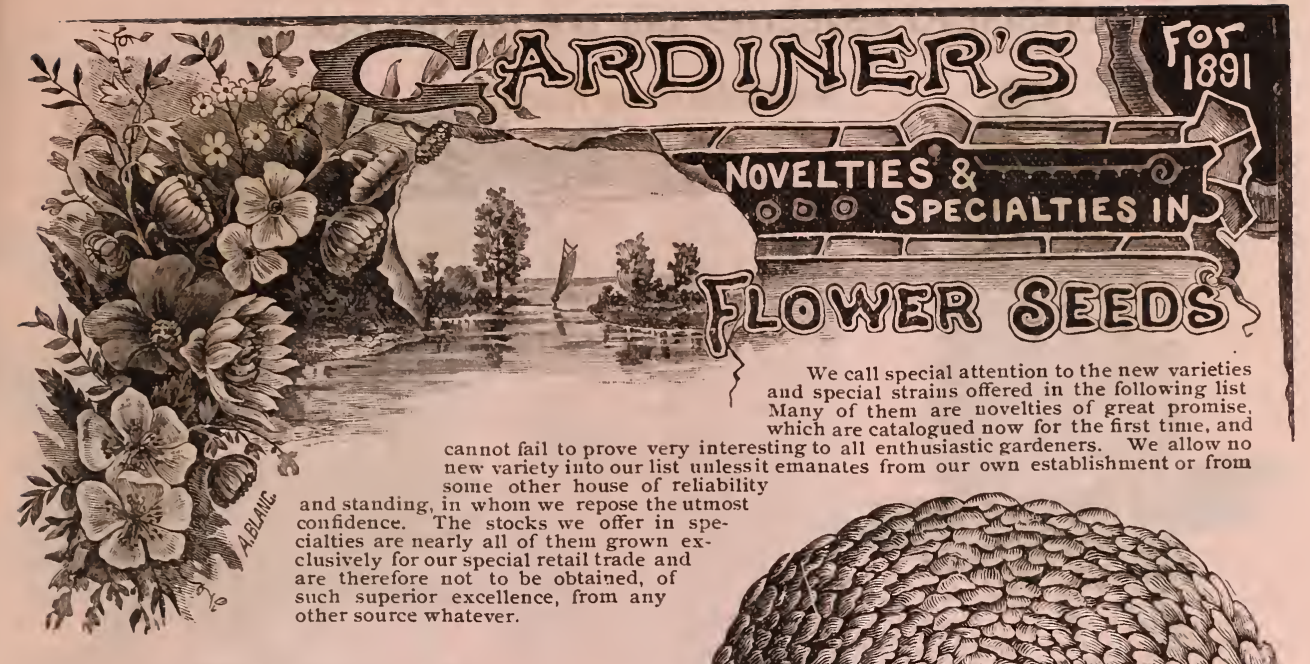

\section{JEWELL ASTER.}

A new and magnificent class of Asters, obtained from the well-known large-flowered Pæony Perfection tribe. Similar, but somewhat dwarfer in habit than the latter. It distinguishes itself at first sight by its beautiful shorter-petalled and perfectly round flowers, which may be compared to the finest varieties of the incurved class of Chrysanthemums. Our engraving of the single flower shows the noble form of the flowers better than it can possibly be described. The plants attain a height of about 20 to 24 inches; the fully developed flowers, measuring from $21 / 2$ stalks, they will prove very useful for cutting and bunching. Two colors, deep rose and apple blossom. Each pkt. $35 \mathrm{c}$.

\section{ZULU KING ASTER.}

This novelty furnishes a color hitherto unknown amongst Asters-a deep black purple-the darkest in color of any yet introduced. The flowers are of faultless globular shape, borne on long stems, thus making them of great value for bouquets. The habit of the plant is pyramidal, as shown in our engraving, and it is a profuse bloomer and a vigorous healthy grower. Pkt. $25 \mathrm{c}$.

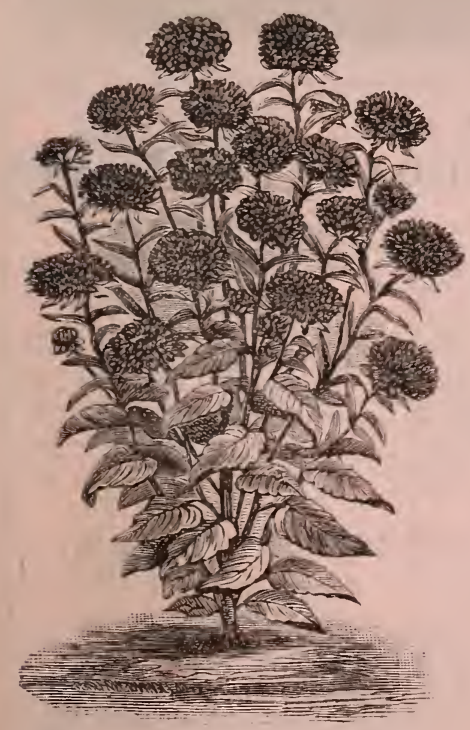

ZULU KING ASTER.

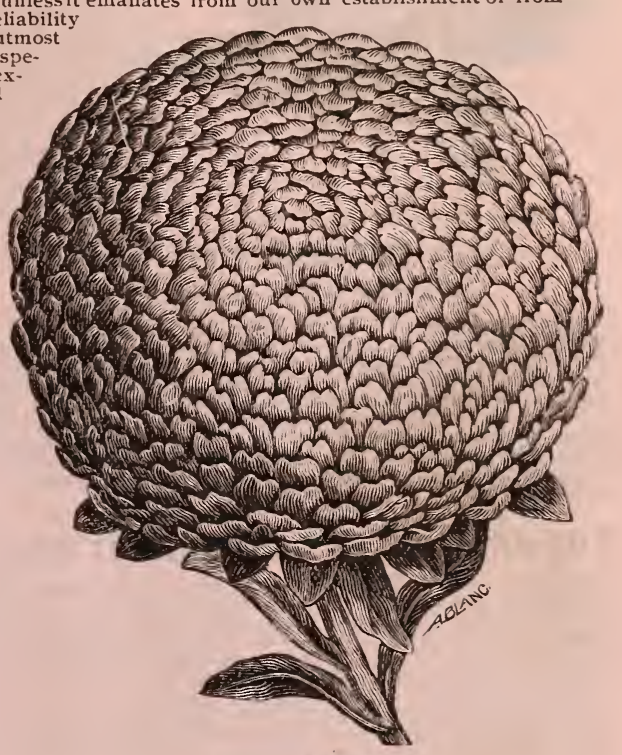

JEWELL ASTER.

\section{PRINCESS OR} SNOWBALL ASTER.

A beautiful and distinc variety, the first of a new race originating from the "Mignon," introduced some years ago. The flowers are semi-spherical, as shown in our engraving: of refined and faultless form ; pure white; beautifully imbricated and very freely produced, as many as 30 flowers being frequently borne on a single plant. The cut blooms will remain longerin good condition than most other varieties; and this sort has the additional advantage of being well adapted for pot culture. This will undoubtedly prove a valuable acquisition to the Aster f a mily, being a novelty of decided merit and the forerunner of a distinct new class. Pkt.

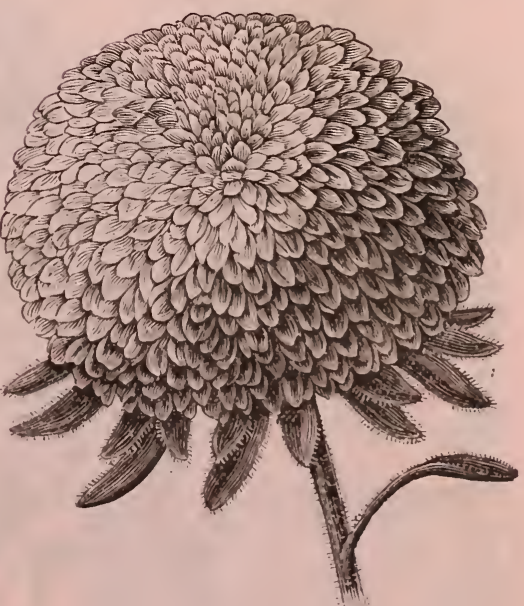

PRINCESS OR SNOTYALL ASTER. 


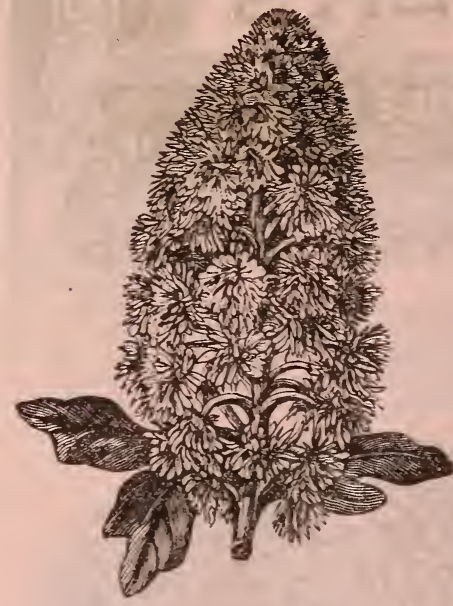

Elmivood Giavt Mig sosette.
New Double Annual Hybrid Chrysanthemums.

(Chrysanthemum Carinatum Fl. Pl.)

This valuable and most unique novelty has resulted from carefully hybridizing and selecting for several years the semi-double varieties of this useful annual already existing, until a high degree of doubleness has been attained. They are extremely variable and it is impossible to describe the beautiful forms which have been produced, as conveyed by our engraving. Some are pure white ellow or crimson, but the prevail ing types are bronzy yellow, the florets tinged with red or lilac rose, the imbricated ray floret beautifully pencilled, others have rich crimson centres with clear yellow guard petals. Although mostly very double, there will still be an occasional semi-double or even single, but these are almost equally charming. The Horticultural Press have giren most favorable comments respecting this novelty. Pkt. $25 \mathrm{C}$.

MIGNONETTE.

ELMWOOD GIANT.

This Mignonette is a special selection of a famous grower whose Mignonette spikes have always excited the wonder and envy of his competitors. The plants are of a robust pyramidal habit; fine healthy growers. 'i hey throw up very large spikes of reddish-tinted, deliciously fragrant flowers. Unsurpassed for pot or bench culture, owing to its dwarf, compact habit and its large, handsome spikes of flowers. Leaves are dark green, of clean, vigorous growth. Does equally well for out-door culture as in the green-house. Very hardy. The finest for amateur or market gardener. Pkt. 10c., oz. \$1.50.

\section{CUP AND SAUCER CANTERBURY BELL.}

of all the odd shapes in flowers of recent introduction, we think this departure in the old-fashioned and ever popular Canterbury Bell is one of the most remarkable. Our engraving gives a fair idea of one of these, and there are many others in this strain of even more pronounced variation from the old style. This strain is not oniy very remariable, it is also exceedingly beautiful and entirel distinct, and will be quite an acquisition to this class of hardy border perennials. Comprises great rariety in coior and much diversity of form and habit, well in rich soil and are of the easiest cultivation. Plst. I5c., 4 for $50 c$.
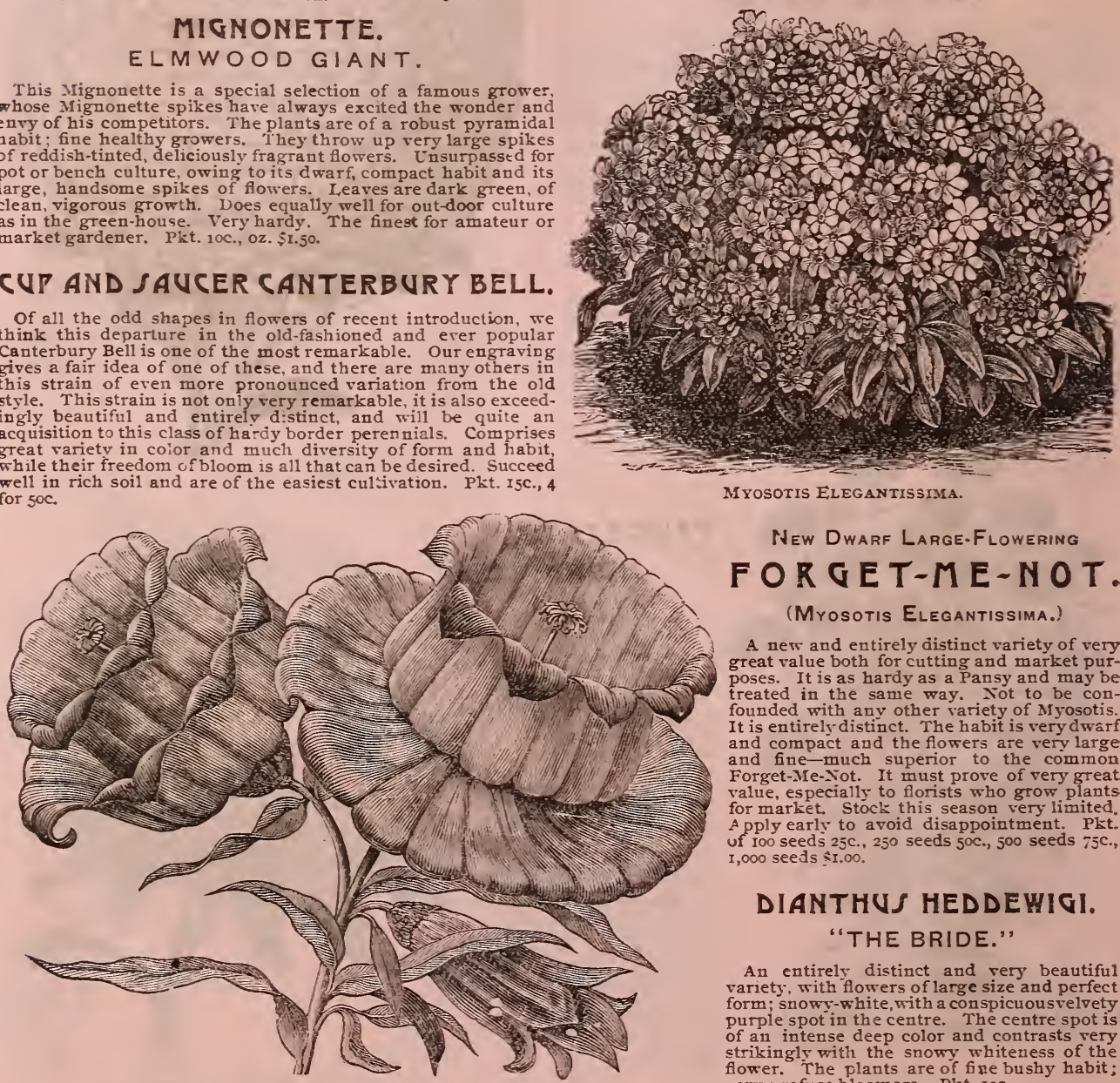

Myosotis Elegantissima.

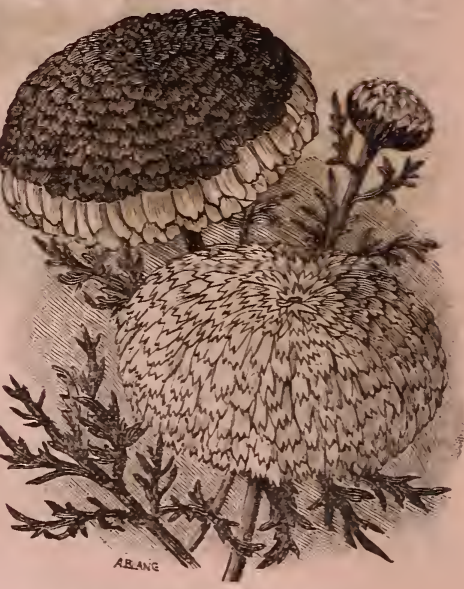

NEW DOCbLE ANNCAL HYBRID ChRYSANTHEMUXS.

New Dwarf Large.Flowering FOR GET-ME-NOT.

(Myosotis Elegantissima.)

A new and entirely distinct variety of very great value both for cutting and market purposes. It is as hardy as a Pansy and may be treated in the same way. Not to be confounded with any other variety of Myosotis. It is entirely-distinct. The habit is very dwarf and compact and the flowers are very large and fine-much superior to the common Forget-Me-Not. It must prove of very great value especially to florists who grow plants for A pply early to avoid disappointment. Plt. of 100 seeds 25 c., 250 seeds $50 c$., 500 seeds 75 c., I, 000 seeds $\$$ I. 00 .

\section{DIANTHUS HEDDEWIGI.}

\section{"THE BRIDE."}

Ap entirely distinct and rery beautiful variety, with flowers of large size and perfect form- snow-white with a conspicuousvelvety purple spot in the centre. The centre spot is pin intense deep color and contrasts very pring strikingly with the snowy whiteness of the
flower. The plants are of fine bushy habit; CtP aNd Satger CaTferbery Bell. very profuse blcomers, Plt, Ioc. 


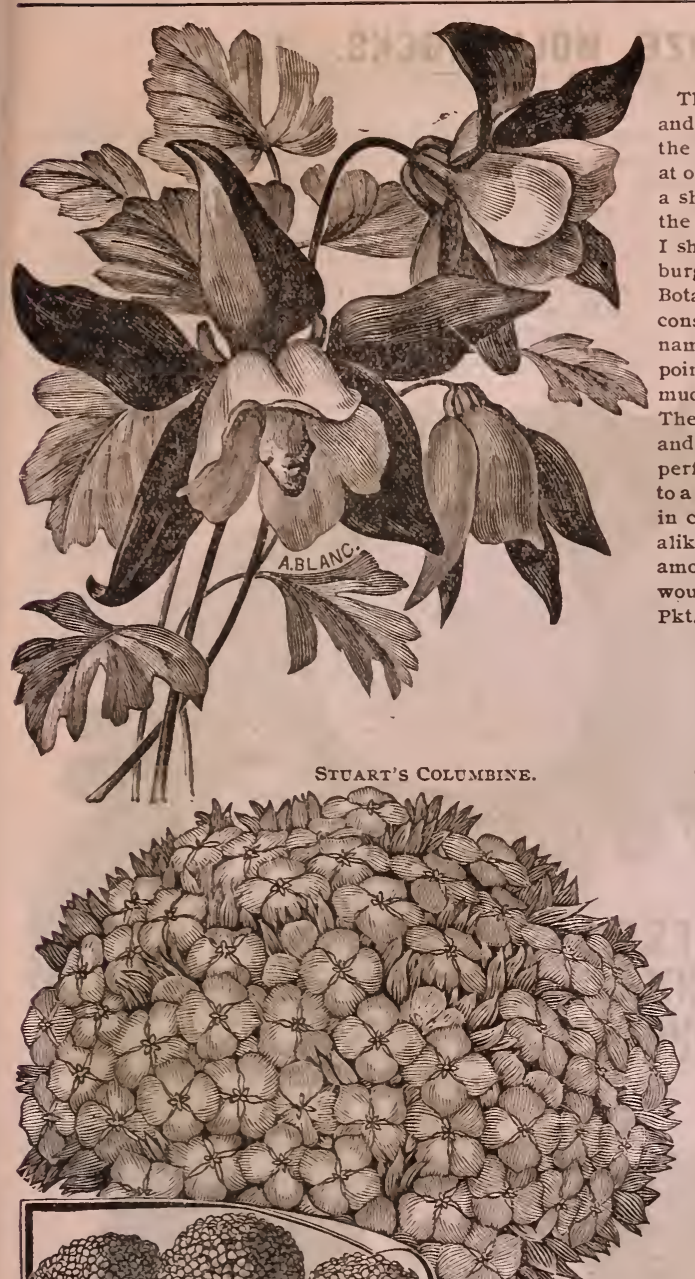

\title{
STUART'S COLUMBINE
}

\author{
(AQUILEGIA STUARTI.)
}

This valuable novelty is a cross between Grigor's Glandulosa and Aquilegia U"itmani. The raiser (Dr. Stuart) says: "From the flower thus fertilized, a pod was gathered and the seed sown at once. Seven plants lived to be plarted out in the autumn in a sheltered border. *** These all bore flowers identically the same, the top blooms ineasuring 4 inches and more across. I showed a quantity of the blooms to Professor Balfour, Edinburgh University, and to John Sadler, Curator of the Edinburgh Botanic Gardens, and to many other competent judges, who all considered it a first-rate novelty, and it was then and there named A. Stuarti by Professor Balfour. I claim the following points of superiority over $A$. Glandulosa for this hybrid : it is much larger, more free-flowering, and far more refined in form.' The much-admired Glandulosa of Grigor is a very shy flowerer, and most veteran gardeners consider it quite a feat to have it in perfection. In the new form raised by Dr. Stuart, this defect is to a large extent removed, and one of the finest herbaceous plants in cultivation is thus brought within the range of cultivation alike to amateurs and professionals. Owing to the limited amount of seed available for distribution the present season, we would advise early application in order to avoid disappointment. Pkt. 25c.

\section{MAR GUERITE CARNATIONS.}

\section{$\frac{\text { A NEW RACE OF CARNATIONS, FLOWERING }}{\text { FOUR MONTHS AFTER SOWING. }}$}

It is seldom that any novelty produces such a general and deserved sensation as this new race of carnations has created. Their distinguishing characteristic and the one which makes this race of supreme im portance, is the fact that they will commence to flower four months after the seeds are sown. The plants are of healthy and vigorous growth, and develop their flowerstalks with great rapidity. The stems arc strong enough to keep erect without support, and the flowers are produced in the greatest profusion. They run through quite a variety of colors-white, scarlet, carmine, rose, striped purple, violet, salmon, etc. Seed sown under glass in March and transplanted to the open ground in May, will commence flowering in August, and will give an endless supply of their beautiful blossoms for a long time. The flowers are exceedingly brilliant in color, and the calyx does not burst. This new race has received the indorsement of some of our most prominent horticulturists, and are acknowledged to be a wonderful acquisition. About 80 per cent. of the plants will come full double. Pkt. $20 c$., 3 pkts. $5 \circ$.

\section{GIANT SPIDER PLANT.}

\section{(CLEOME PUNGENS.)}

This is not a novelty, but an excellent old plant that has been neglected for a long time. It grows to a height of 5 to $6 \mathrm{ft}$. and

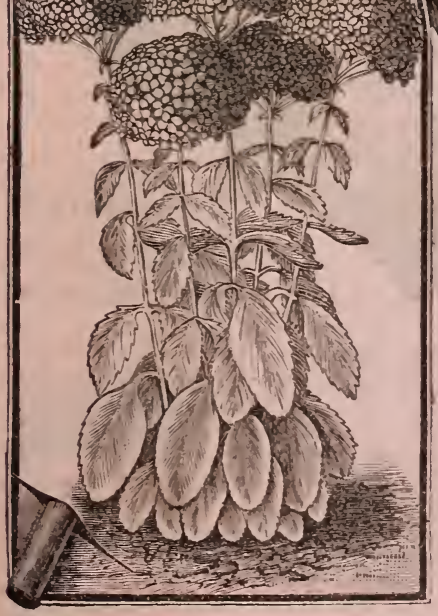

Kalanchoe Cariea. bears large panicles of bloom of a purplish pink, shading to light pink when fully opened. The stamens are several inches long, which gives the plant the popularname Spider Flower. Seeds sown in the open ground in May will commence flowering in July and continue till cut down by frost. 'The spider Flower is one of the best and showiest subjects for backgrounds showiest subjects for background and will stand almost any amount of wind and weather without injury. Pkt. 5c., oz. 5oc.

\section{KALANCHOE CARNEA.}

A new species from the Cape of Good Hope, with large umbels of beautiful pink flowers, delicately, yet sweetly fragrant, borne on long stems and very profusely. It has a peculiar and pleasing fragrance, and grows quite readily from seed. Thrives best in a mixture of loam and sand. Pkt. $15 \mathrm{c}, 2$ pkts. $25 \mathrm{c}$.

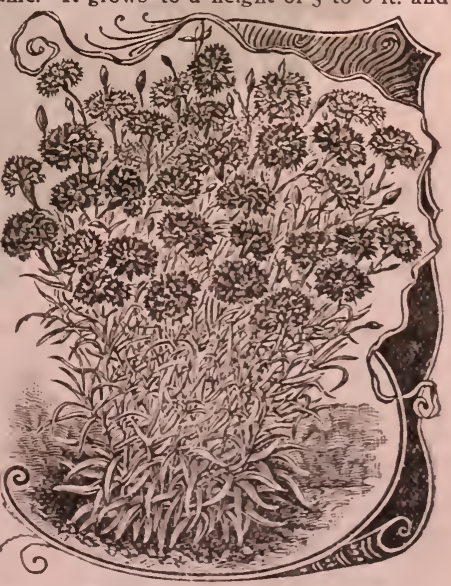

MARGTERITE CAKNATIONS. 


\section{$\star \rightarrow-\sigma$ CHATER'S PRIZE HOLLYHOCKS.}

The remarkable richness and variety of color in this prize strain has excited the wonder and admiration of all beholders. At the leading Horticultural Exhibitions they have taken first rank for their magnificent spikes of flowers as well as for their unrivalled richness and delicacy of coloring. The flowers are superbly double. and the colors embrace the richest shades of yellow, rose, crimson, primrose, lavender, maure, white, etc. Now that the pendulum of fashion in the world of gardening is on the return swing from the extreme use of soft wooded plants to the more extensive use of herbaceous plants, the Hollyhock is certainly one of the first of our old farorites to be reinstated to the prominent position it formerly held as a decorative plant. They are far more easily raised from seeds than is generally supposed, and if our instructions are properly followed they can be had in flower the first season, although the usual way is to sow in August for next season's flowering. But there is no reason why this excellent plant should not be had in flower five months after sowing just as well as the Dahlia, which is now quite extensively grown in this way.

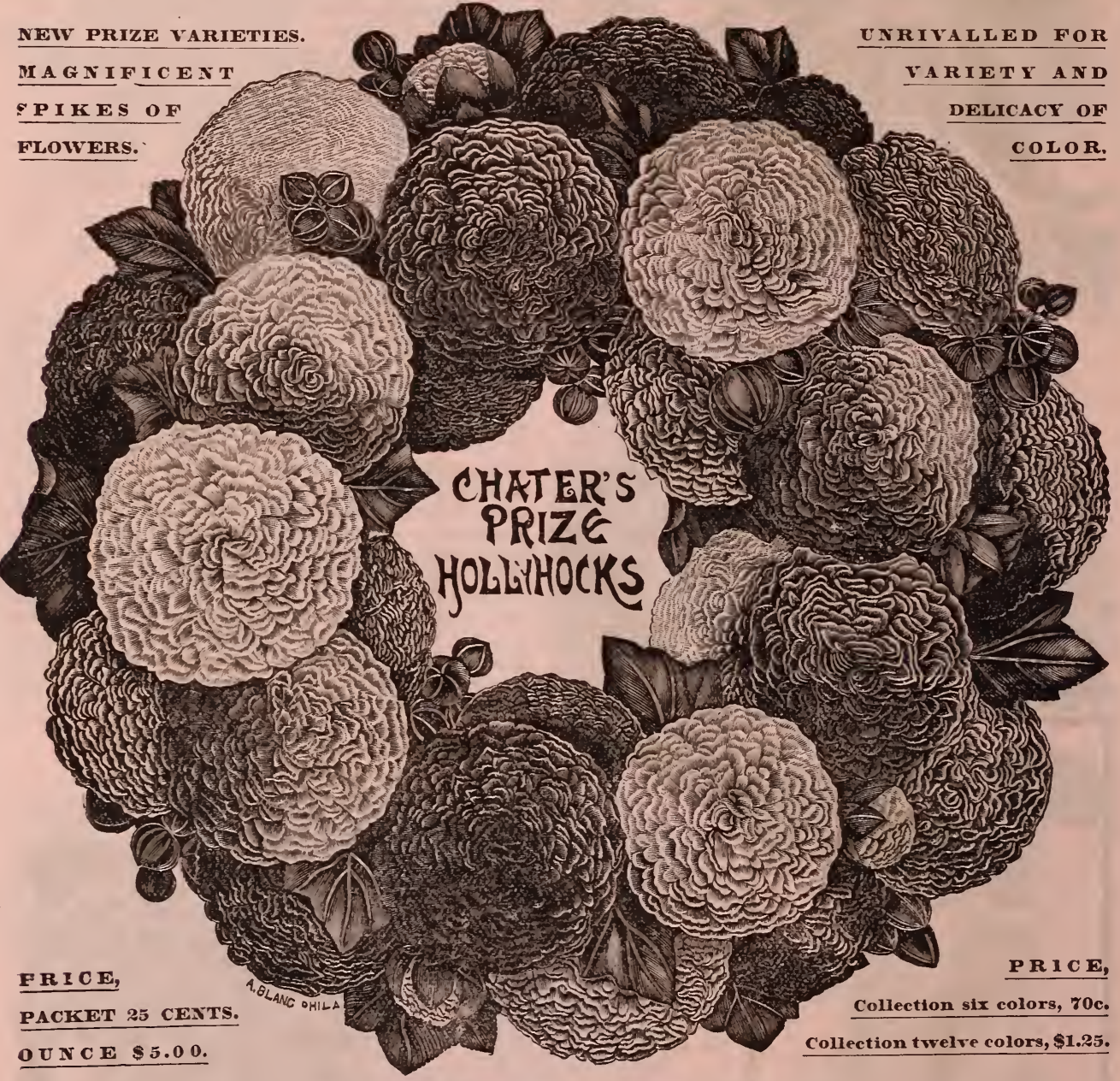

HOW TO FLOWER THE HOLLYHOCK THE FIRST SEASON FROM SEED. - Sow the seed in February me temperature must not be too high, and it is best to sow the seed directly on the soil-not using any pans or boxes. A good loamy soil is best. Cover the seeds to a depth of one-half dire should be pricked out and transplanted inch without heat, but well protected from frost. As early in spring as the weather will permit, which in the first of Jas, the soung plants may be transferred to their permanent quarters. if them during the night and removed on the following morning. Continue to do this until all danger of frost is past. By following the trouble will be amply repaid with fine spikes of flowers in the following August and September. Those who do not possess a frame or hot-bed can raise the seed in a sunny window;

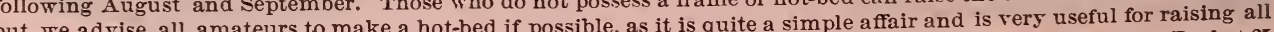
kinds of seeds-Stocks, A sters, Pansies, and a host of others. Chater's Prize Hollyhock, choicest mixed.-Packet 25 sents, ounce $\$ 5.00$. Collection of six colors, 70 cents. Collection of twelve colors, \$1.25. 


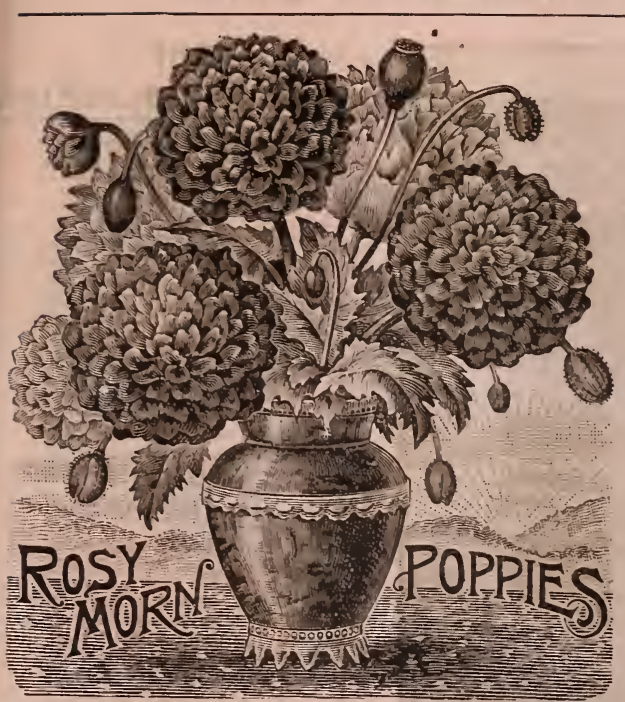

\section{GIANT A WHITE \& DAISY.}

(Pyrethrum Uliginosum.)

A GEM FOR CUT FLOWERS.

An excellent herbaceous perennial, bloom. ing first season from seed; bears very large, pure white, single flowers; profuse bloomer
and excellent for cutting. Pkt. $15 \mathrm{c} ., 4$ for $50 c$.

\section{NEW}

\section{AMERICAN SWEET PEA.}

\section{"Miss Blanche Ferry."}

Compared with Painted Lady-the most popular sort on the whole hitherto for market purposes-the flowers of this novelty have a far deeper, richer coloring and greater fragrance. It is also dwarf and compact, very early, free-flowering and bears hue large than most others. Pkt. 5 c., 12 pkts. 5oc., oz. $40 \mathrm{c}$.

\section{^ $\quad$ ROSY 4 MORN POPPY A \\ (Papaver Peoniflorum Var.)}

This new Poppy is a really superb novelty. All who tried it last season for the first time were greatly struck with its beauty. The flowers are extremely double and of good size, forming perfect balls of a most unique and beautiful shade of rose-an entirely new and distinct color in Poppies. We consider this quite an acquisition. It is of the easiest possible culture, belonging to the anuual pæonyflowered section and merely requires to be sown where the plants are to flower. Those who have not already tried this novelty should not fail to do so. Pkt. Ioc.

\section{\& $\quad$ CELANDINE POPPIES $\hat{\Delta}$ ث}

This free-flowering and beautiful class of Poppies oupht to be more extensively cultivated. Flowers are single, fragrant. Colors arlet and yellow. Hardy perennial. Mixed. P'kt.

\section{^ PLYMOUTH • PETUNIAS *}

\section{(HENDER's Strain.)}

Probably the finest strain of Petunias in existence at present. We know of nothing to equal them either for size, substance or color. Superb in every way. A prominent grower writes us: "The fringed and all have immense flowers and fine colors." Single, plt. $25 \mathrm{c}$; d double, pkt. $50 \mathrm{c}$.
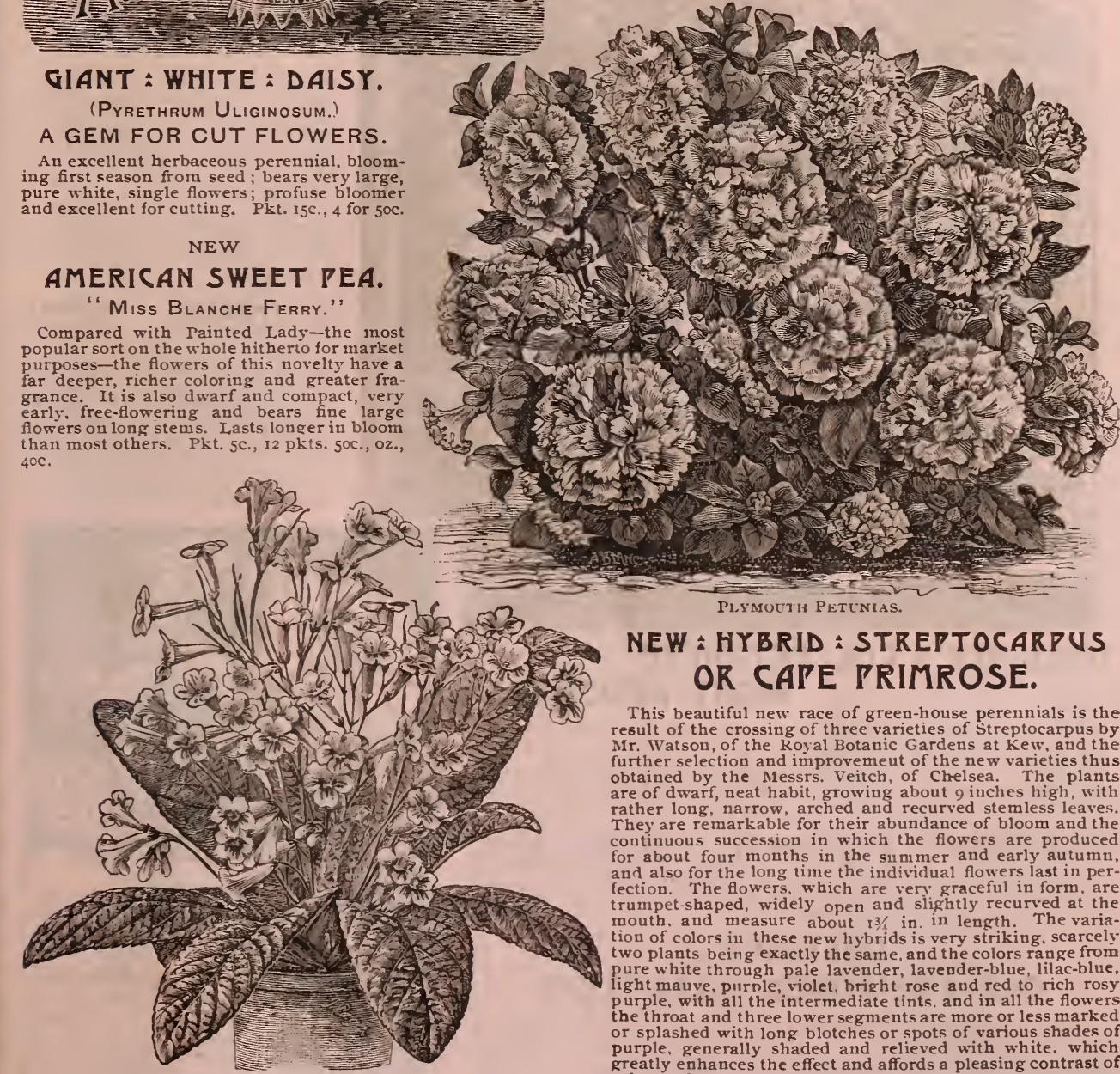


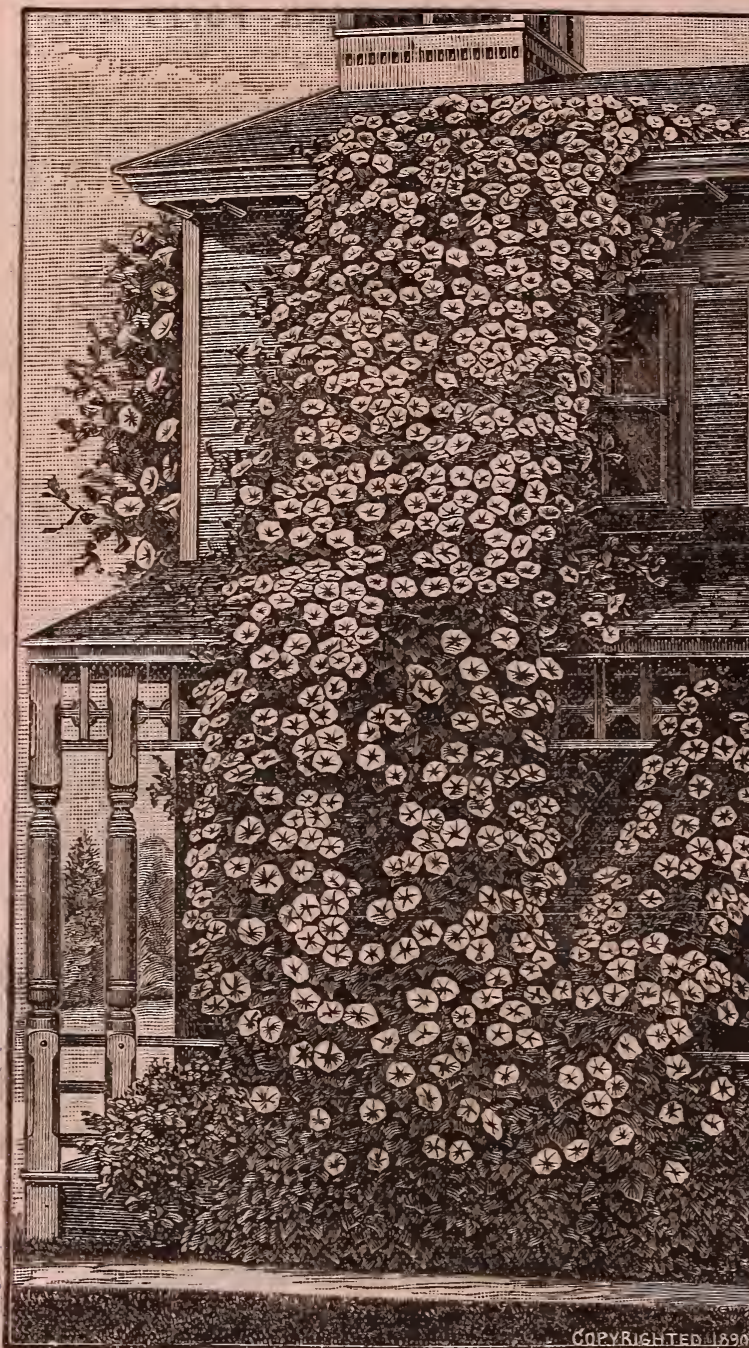

\section{GARDINER'S COLLECTION OF NIGHT-BLOOMERS.}

Our celebrated collection of these contains some very charming sorts, all of them delightfully fragrant during tie evening, and many of them opening their blossoms in the earlier part of the day as well. The collection includes the Moonflower, Evening Stock, Four-o'clock, Evenvarieties (I pkt. each), 50c., 25 varieties (I pkt. each), SI.00.

\section{GARDINER'S AESTHETIC COLLECTION.}

A most unique and charming collection, the chaste and simple forms of which are particularly pleasing and possessed of great variety and richness in coloring. I2 varieties ( 1 pkt. each), $50 c$.

\section{GARDINER'S OLD-FASHIONED COLLECTION.}

Give the old-fashioned blossoms a chance. Their quaint names and grandmotherly associations, "

should gire them a place in the affections of all good gardeners. I2 varieties (I pkt. each), 50c
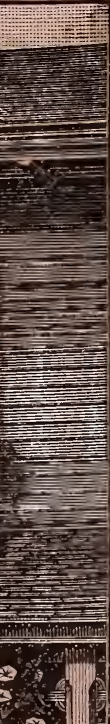
$+x^{*}$ . .
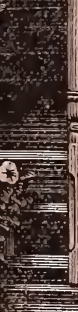

$\triangle$ THE $\Delta$

HARDY DAY BLOOMING

\section{MOONFLOWER.}

(Ipomata Pandurata.)

This vine is propagated from tubers, and is hardy as far north as Boston. It is a remarkably quick and vigorous grower, making as high as $25 \mathrm{ft}$. in a single season. It produces a perfect mass of foliage, forming a dense same down to the ground until frost. The flowers a re white (shading to pink) with purple throat, $3^{1 / 2}$ to 6 ins. in diameter, and are borne in the greatest profusion (as many as I, 200 open blooms have been counted on one vine at one time), and the blooming The root is perennial and may be left in the ground during winter. Unlike the Ipomoea Grandifora the flowers open during the day, and this fact taken in conjunciton with its quick-growing character and hardiness, renders it of beautiful, hardy and quick - growing beautiful, hardy and quick - growing acter of the root is also a feature that will be a great recommendation, as the tubers once planted may be left in the ground permanently. The sensation created by the Night-Blooming Moonby this remarkable introduction, and we anticipate a very large sale for the in rotation. Send early. I5c. each, 8 in rotation, send

for $\$ 1.00$ (free by mailly selected lot of large and fine tubers which are suitable for shipping by express only (being too large for mailing), $25 \mathrm{c}$, each; $\$ 2.5^{\circ}$ per doz.

SPECIAL A OFFER.

For $30 c$. we will mail free, two tubers of the new Day-Blooming Moonflower, and one packet seeds of the N I G H T - B L FLOWER (Ipomcea Grandiflora) if ordered together ; 5 tubers and 2 packet seeds for $75 \mathrm{c}$. It must be distinctly understood, however, that these two in order to secure this reduction.

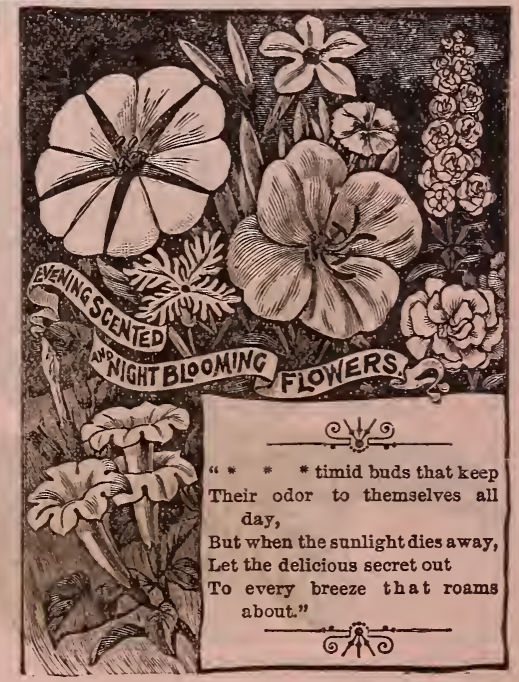




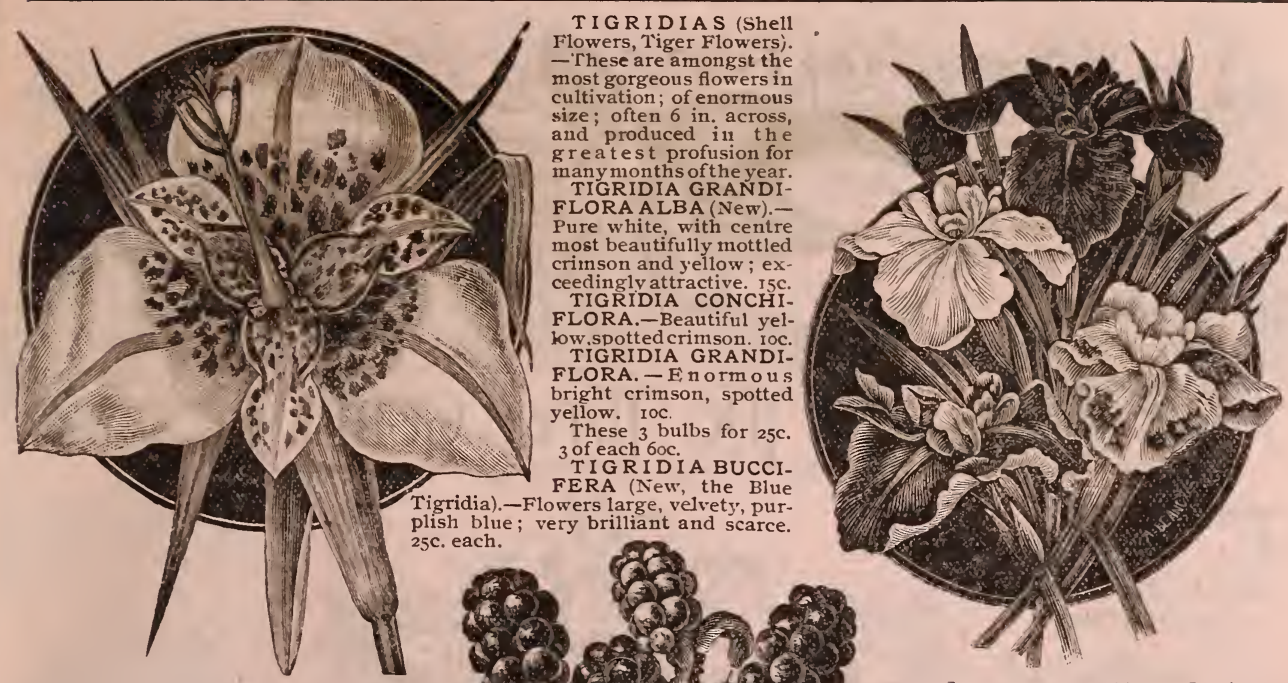

TIGRIDIA.

CRINUM KIRKY.-This magnificent bulb, which often attains the size of 6 to 8 inches, producing flowers of the greatest beauty. Usually two flower stalks of dark purplish color are sent up at the same time each bearing a large umbel composed of a dozen or more enormous lilylike flowers of the greatest beauty and fragrance. The petals are broad and pure white, with a deep reddish purple stripe through the centre. A pla creates a sensation when it blooms, which large bulbs are usually sold at $\$ 3$ to $\$ 5$. Our price is $\varsigma_{1}, 3$ for $\varsigma_{2}$

GAY QUEEN Or QUEEN LILY.-So called on account of the beauty of the called on account of the beauty of the called Phadranassa, which bears large umbels of showy flowers, 2 to 4 inches umbels of showy flowers, 2 to 4 inches of the easiest growth, blooming freely and producing fine foliage as a pot plant. W have three sorts, viz:
PHÆDRANASSA

Flowers purplish rose tipped RACEA.-

PHEDRANASSA GLORIOSA.-Scarlet, yellow and green. A scarce variety.

30c. EAch, 2 for $50 c$. Most curious green and yellow flowers fine bulbs. $20 \mathrm{c}$. 3 for 5 oc. dress for $60 c$.
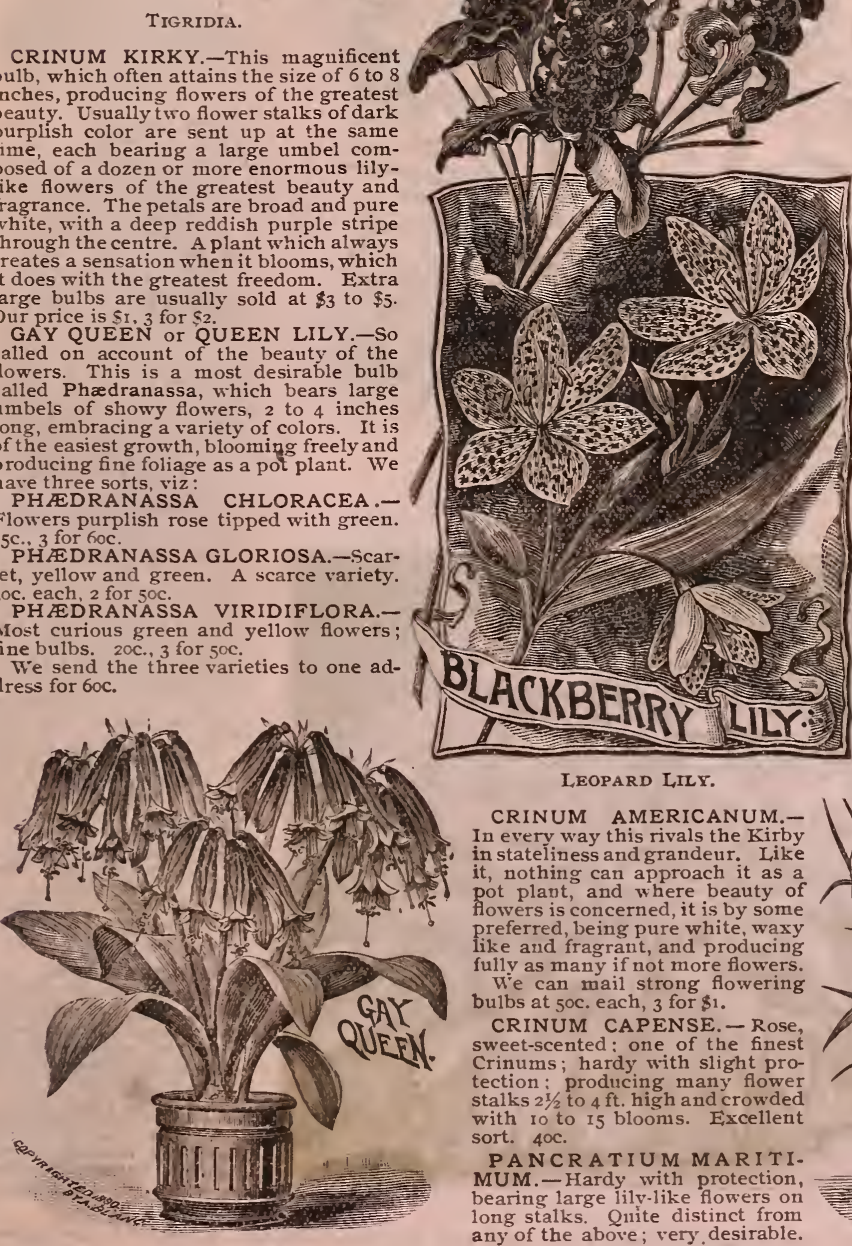

IRIS KEMPFERI (JAPAN IRIS).

IRIS KAEMPFERI (Japan Iris).-No nore noble, brilliant and interesting fowers than these can be produced. 作 out during winter. Elegant near edges of streams, etc. Our collection is a careful selection of all colors. 25c. each, 5 for $\$ I$.

THE LEOPARD LILY OR BLACKBERRY LILY is the name given to Pardanthus Sinensis, a most curious Chinese lily, bearing on stalks 3 to $4 \mathrm{ft}$. high a large number of flowers of the richestcolors, yellow and orange spotted with purple and black. These flowers scarcely be distinguished from a blackberry, and these are used for ornaments and for mixing with bouquets of dried grasses. A fine hardy plant deserving a place in every garden. Each $1_{5} \mathrm{c} ., 3$ for $40 \mathrm{C}$., 10 for $\$ 1.00$.

PEACOCK FLOWER (Mraea Pavonia).-A most distinct and curious flower of which the beauty can only be shown in a colored plate. Our small cut gives an idea of the flowers, which are of the purest white marked with a black eye blended with blue and purple: increases ra pidly and is perfectly hardy: much admired in England. $15 \mathrm{c}$. each, 4 for $50 c$.

LEOPARD LILY.

CRINUM AMERICANUM.In every way this rivals the Kirby in stateliness and grandeur. Like it, nothing can approach it as a pot plant, and where beauty of flowers is concerned, it is by some
preferred, being pure white, waxy like and fragrant, and producing fully as many if not more flowers. We can mail strong flowering bulbs at 50c. each, 3 for $\$ 1$.

CRINUM CAPENSE - Rose, sweet-scented; one of the finest Crinums; hardy with slight protection: producing many flower stalks $21 / 2$ to $4 \mathrm{ft}$. high and crowled sort. $40 \mathrm{C}$.

PANCRATIUM MARITIMUM.-Hardy with protection, bearing large lilv-like flowers on long stalks. Qnite distinct from any of the above; very desirable. Phedranassa.

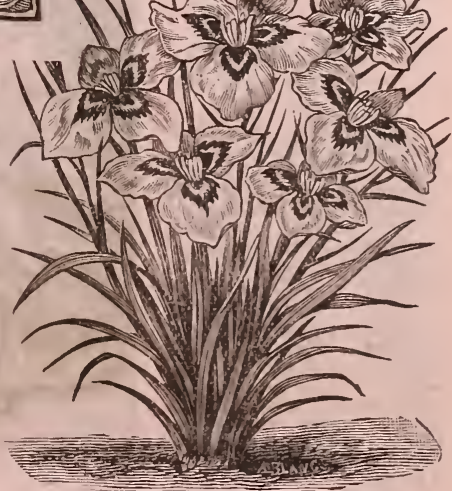

Peacock Flower (Morea Patonia). 


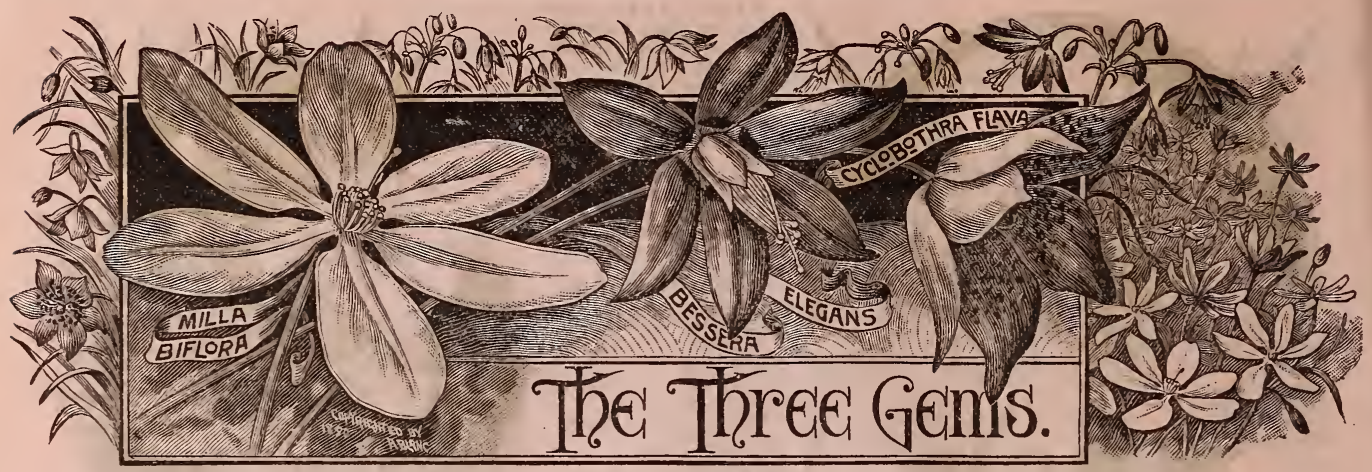

THE THREE A IA A GEMS. MILLA-BESSERACYCLOBOTHRA.

MILLA BIFLORA (Frosty Milla). Gem No. I. Delightfully fragrant, white waxy-like flowers, enlightened by a living sparkle. As many as eleven flower stalks Ioc. each, 3 for 25 c., 7 for $50 \mathrm{c}$.

BESSERA ELEGANS (Coral Drops). Gem No. 2. being planted shortly after tinue until frost. Flower stems I to 2 feet high, flowers bell-shaped, bright coral scarlet with white cups and dark blue anthers. roc. each, 3 for 25 C., 7 for 50 .

CYCLOBOTHRA (Golden Shell). Gem No. 3. Quite distien yellow, with are black dots in the petals; profuse bloomer and very effective. Ioc. each, 3 for $25 \mathrm{c}$., 7 On 5 bulb of each of the above for $2.5 \mathrm{c}$., 3 of each for $60 \mathrm{c} ., 6$ of each for $\$ 1.00$.

AMARYLLIS BELLADONNA is a well-known hardy Amaryllis, but the sort we offer here is a greatly improved variety, bearing larger flowers of brighter a deep rose tint and they are produced in the greatest lished in the garden or in pots. Extra large buibs, $30 \mathrm{c}$. each, 4 for $\$$ I.00.

AMARYLLIS EOUESTRE is an equally desirable bulb for pot culture, bloom. ing almost assoonas planted. The flowers often measure 5 inches across, beautiful orange, shaded to clear green in centre. Improves yearly and sure to delight. Large bulbs, $25 \mathrm{C}$., 2 for $40 \mathrm{C}$.

AMARYLLIS FORMOSISSIMA. No Amaryllis can approach this in brilliancy of color which is of the deepest. most intense velvety scarlet. One of the rarest and richest colors among flowers. 20c, each, 3 for 5 oc.

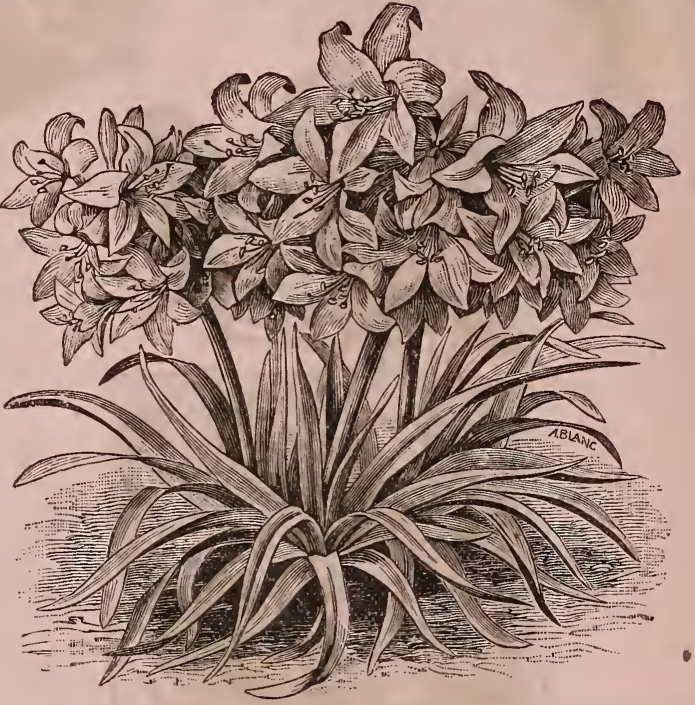

AMARYLLIS BELLADONNA.

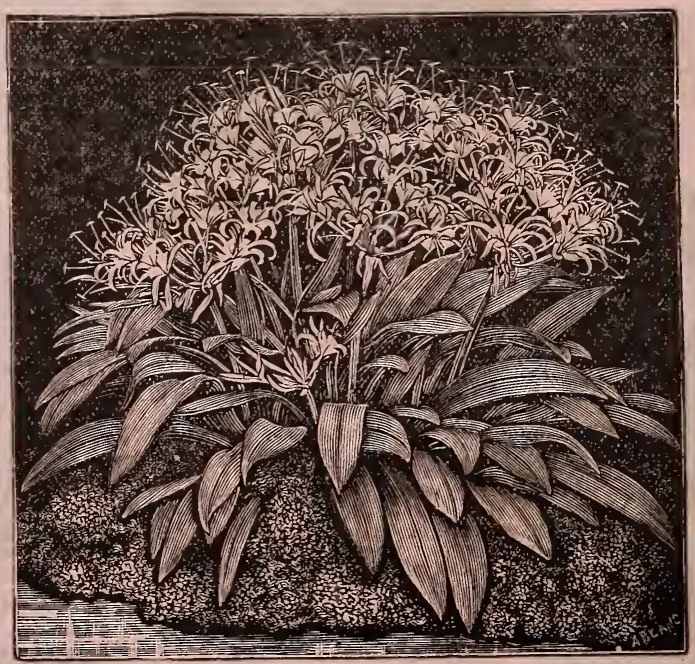

SPIDER LILY.

One bulb of each of above would cost, at regular rates, \$2.15 for $\$ 1.50$.
Z E P H Y RA NTH ES Zephyr Flozvers). Of easiest growth, producing spike a amaryllis-like flowers, most delicate and attractive. We have three varieties, viz: $Z$. Atamasco, pure white, roc. 3 for 25c.; $Z$. Rosea, pink, roc. each, 3 for $25 \mathrm{c}$. and tirely of a rich coppery yellow; a fine sort $25 \mathrm{c}$ each One of each of the above for 35c.

HYACINTHUS CANDICANS. A perfectly hardy Hyacinth, blooming during August and September. Its fine large bell-shaped flowers of greenish white are borne on spikes often 4 to 5 roc. each, 3 for $25 \mathrm{c}$., I 2 for $75 \mathrm{C}$.

CAMASSIA ESCU. LENTA. In contrast to the above we are pleased to offer this fine blooming hardy bulb, similar in growth to H. Candicans, but bearing fowers of a beautiful shad first tinie and are sure that it will prove an acquisition. I5c. I Hyacin thus and I Camas. sia for 20c., 3 of each for $50 c$. THE SPIDER LILY. That this fine Southern more popular before is only due to its former high price. Now that it can be obtained so cheaply,thousands a re being sold. Strong bulbs, such as spikes, crowded with dozens f the most fragrant white flowers imaginable, which will expand daily for many weeks. A single spike cut off and placed in water when the first flowers begin to open will keep on blooming for two weeks and often longer, fllling a room with their delightful fragrance. In mild localities the bulb is hardy. 2oc. each, 3 for $50 c$.

\section{MADEIRA VINE. Well} known roots of rapid growth, soon covering an arbor with dark green foliage, covered in the fall with clusters of white, sweet-scented flowers. Ioc. each, 3 for $25 \mathrm{c}$.

APIOS TUBEROSA. Somewhat similar to the above, but bearing clusters af purple Wistaria-like flowers, which are very fragrant. IOc. each, 3 for $25 \mathrm{c}$. 


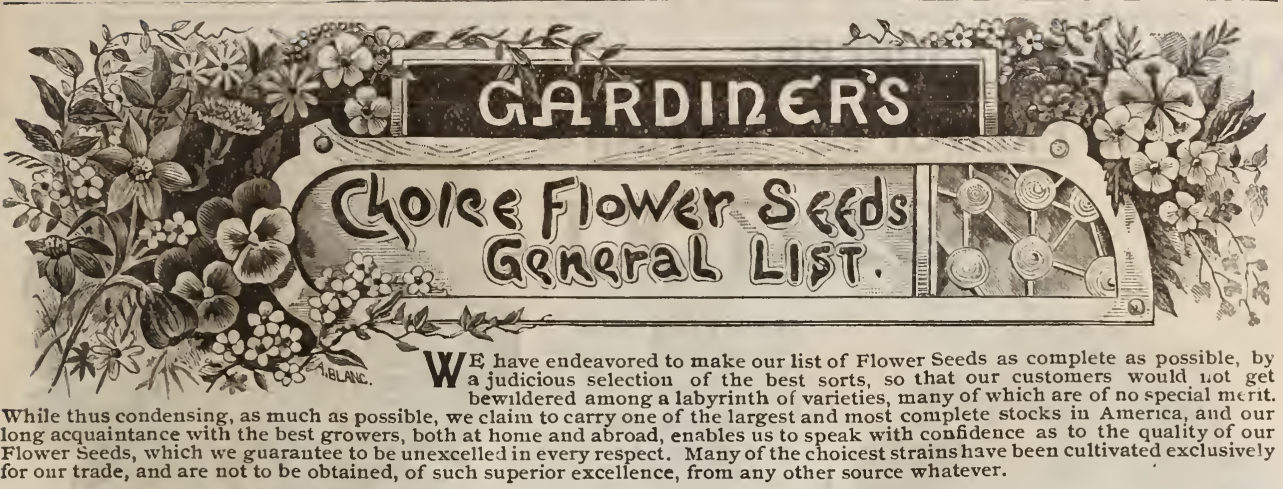
SEEDS B Y M A I L, POST-PA I D. ALL FLOWER SEEDS ARE SENT BY MAIL,

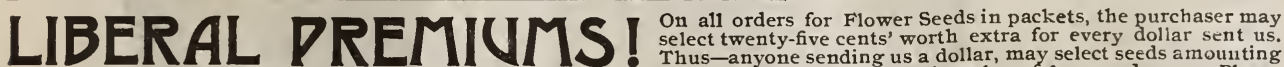
Thus-anyone sending us a dollar, may select seeds amounting tell your friends of our liberal offer. This discount applies to packets only. Postage stamps received the same as cash.
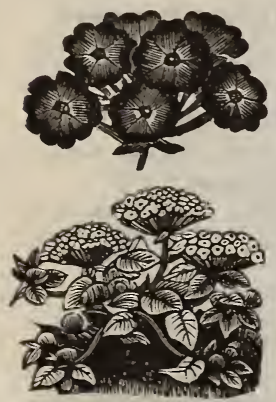

ABRONIA UMBELLATA

\section{ABRNIA.}

Charming trailer, with beautiful verbena-like clusters of sweetcented flowers; continues in bloom a long time; very effective in beds, rock-work, or hanging baskets. Annuals.

Umbellata.-Rosy-1ilac, fragrant. $1 / 2 \mathrm{ft}$. Pkt. 5c., oz. $75 \mathrm{C}$.

Arenaria.-Yellow. $1 / 2 \mathrm{ft}$. Pkt. 5c., oz, $\$ 1.00$

\section{ALYSSUM.}

Neat and ornamental species; well adapted for rock-work, flowerbeds, and borders. Makes an excellent pot plant for winter, and very desirable for window boxes. Hardy.

Benthami (Szveet Alyssum). -White. Annual. 1/2 ft. Pkt. 5c., oz. 5oc.

Benthami Compactum.-New; very pretty ; white. Pkt. $5 \mathrm{c}$., oz. $75 \mathrm{c}$. 5c., oz. 75 c.

\section{ALONS:A.}

Brilliant, easily grown annual suitable for in-doors or the summer garden; very desirable. White and scarlet. Each, pkt. 5c., oz. $50 \mathrm{c}$.

AGROSTEMMA.

Handsome, free flowering, attractive border plants, at home in any garden; excellent for cut flowers. Coronaria Atrosanguinea (Rose Campion).-Crimson. Perennial. 2 ft. Plet $5 \mathrm{C}$. $50 \mathrm{C}$

Coronaria Alba.-White. Perennial. $2 \mathrm{ft}$. Pkt. 5c., oz. $50 \mathrm{c}$.

Coli Rosea (Rose of Heaven) Deep rose. Annual, I ft. Pkt. 5c., oz. 35c.

nual. I ft. Pkt. 5c., oz. $35 \mathrm{c}$.

\section{ANAGALLIS.}

\section{(PIMPERNEL.}

Called also " Poor Man's Weather Glass." Very handsome, dwar annuals; excellent fo

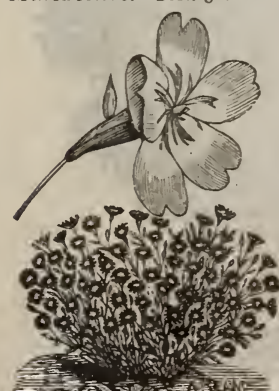

AQROSTEMIMA CORONARIA. 'ROSE CAMPION."
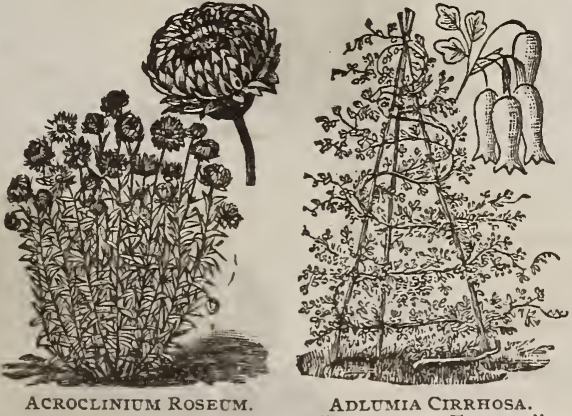

ADLUMIA CIRRHOSA.

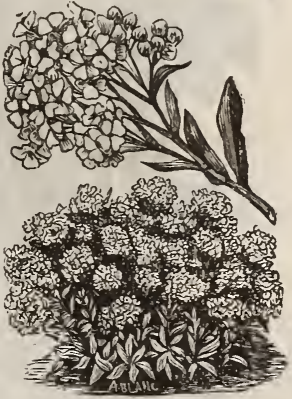

SWEET ALYSSOM

\section{AMARANTHUS.}

\section{Foliage plant with very hand-} some leaves and flowers. The fuliage is most brilliant and striking in nearly all the varieties, rendering them objects of great beauty for the summer garden. Of easy culture. Annuals.

Caudatus (Love-lies-bleeding).Crimson. 3 ft. Pkt. 5c., oz. 35c. Cruentus (Princes' Feather)Scarlet. $3 \mathrm{ft}$. Pkt. 5c., oz. $35 \mathrm{c}$. Salicifolius (Fountain Plant).Highly-colored drooping foliage. 4 ft. Pkt. 5c., Oz. \$1.00. Tricolor (Joseph's Coat).-Red yellow, and green. Tery ornat.
tal. $3 \mathrm{ft}$. Pkt., 5c., oz. 35c.

\section{ACROCLINIUM.}

One of the most beautiful and valuable of the everlasting flowers, and grown extensively for winter bouquets. Sow in hot-beds, and transplant. Annuals.

Album. - Single white. I ft. Pkt. 5c., oz. $30 \mathrm{c}$.

Album, fl. pl.-Double white. If $\mathrm{ft}$ Pkt. Ioc.

Roseum.-Single bright rose. I ft. Pkt. 5c., oz. $30 \mathrm{c}$

Roseum, ft. pl.-Double rose. I ft. Pkt. Ioc.

\section{ADLUMIA.}

MOUNTAIN FIINGE.

A beautiful perennial climber, with elegant foliage, resembling the maiden-hair fern. Sow the seed in May where they are to remain, and they will blooin the following season.

Cirrhosa.-Pink. Io ft. Pkt. 5c., oz. \$r.5o.

\section{ACACIA LOPHANTHA.}

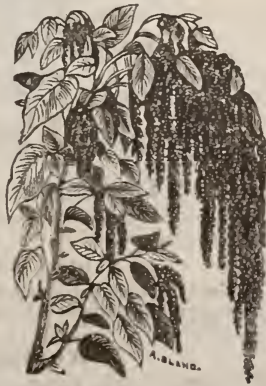

Graceful, ornamental green-house shr.h, with hnndsnme spikes of A MARANTHUS CAUDATCS yellow flowers. İi. roc., uz \$1.00. Acaci. mixed, 1,kt. 10c., 0z. \$:.00.

"LOVH-LIES-BLEEDTNG," 


\section{G ARDINER'S - SUPERB .}

\section{* FRENCH AND GERMAN * 〜๑ASTERS.}

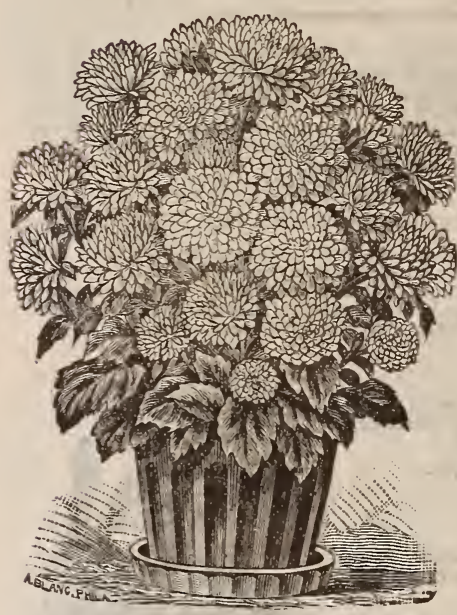

BOLTZE'S DWARF BOCQTET ASTER.

\section{Triumph.}

A very dwarf and com pact race, with beautiful imbricated flowers. The colors are very distinct and charming, and, from experience, have proven quite an acquisition to ourlist of dwarf Asters. DARK SCARLET.-Pkt. I5C. DARK SCARLET AND WhITE.-Pkt. I5C.

\section{Comet.}

Delicate pink bordered with white the petals being long, twisted and curled like Japanese Chrysanthemum; same height and

\section{Comet, Deep Rose}

An exact counterpart of the preceding, only the flower is pure deep rose. Pkt. roc.

\section{Comet Light Blue.}

A new color in this distinct and charming race; beautiful light blue. Pkt. Isc.

\section{Mignon.}

A beautiful pure-white variety, like the Victoria in form and habit, but a more pofuse bloomer and very refined in form. Pkt. I5c. oz., $\$ 5.00$.

\section{Iubricated Pompon.}

Exquisitely formed Pompon flowers; splendid. Pkt. 15c., oz. $\$ 3 \cdot 50$.

Betteridge's Quilled.

The finest type of quilled Aster, very double and beautifully quilled; mixed colors. Pkt. 5c., oz. \$r.0o.

\section{Goliath.}

Immense flowers, very double; mixed colors. Pkt. roc. oz. \$2.50.

Hedgehog or Needle.

A splendid variety with large flowers, and long, sharplypointed petals; mixed culors. Pkt. roc., oz. $\$ 2.50$.

\section{Giant Emperor.}

A variety of large proportions and robust habit, bearing a single immense flower on each stem, very double: mixed colors. Pkt. I5c., oz. $\$ 5.00$.

\section{Washington.}

The largest Aster grown, bearing flowers four to five inches in diameter and very double ; splendid for exhibition; mixed colors. Pkt. I5c.

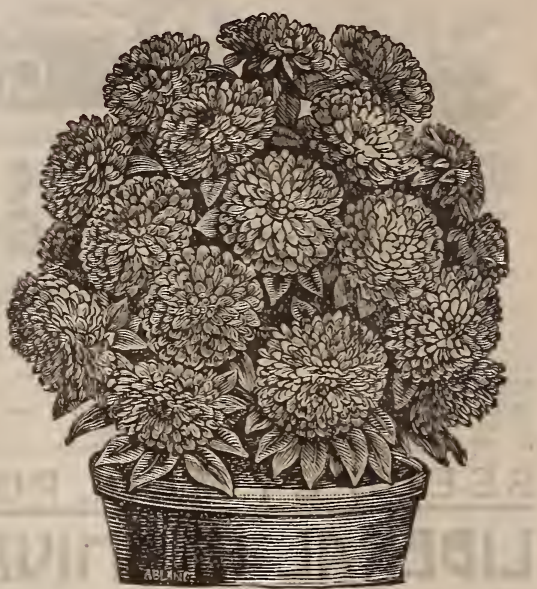

DWARF GERMAN ASTRR.

Boltze's Dwarf Bouquet.

One of the finest dwarf Asters, very profuse bloomer; mixed colors. Pkt. Ioc. oz. $\$ 3.00$.

Dwarf Pyramidal Bonquet. Fine prramidal habit, brilliant colors: elegant ; mixed colors. Pkt. Ioc., oz. \$3.0c.

\section{Liliput.}

New and charming variety with small flowers produced in great abundance mixed colors. Pkt. 1oc., oz. \$1.50; pure whitc, pkt. 15c., oz. $\$ 5.00$

\section{New Queen.}

A new large-flowering class of very fiue dwarf habit not exceeding 9 or roinches in height and bearing profusely full, double imbricated flowers of extraordinary size. Unsurpassed for bedding purposes, and excellent for growing in pots for market. Crimson, Dark Blue, Light Blue, and White. Each, per packet, roc.

Non Plus Ultra (New).

Resembles the Victoria in form of flower perfectly double very large and carried well above the foliage Distinct branching habit, making a circular bush $11 / 2 \mathrm{ft}$. in diameter and not more than 15 in. in height. Mixed colors. Pki. I5c.

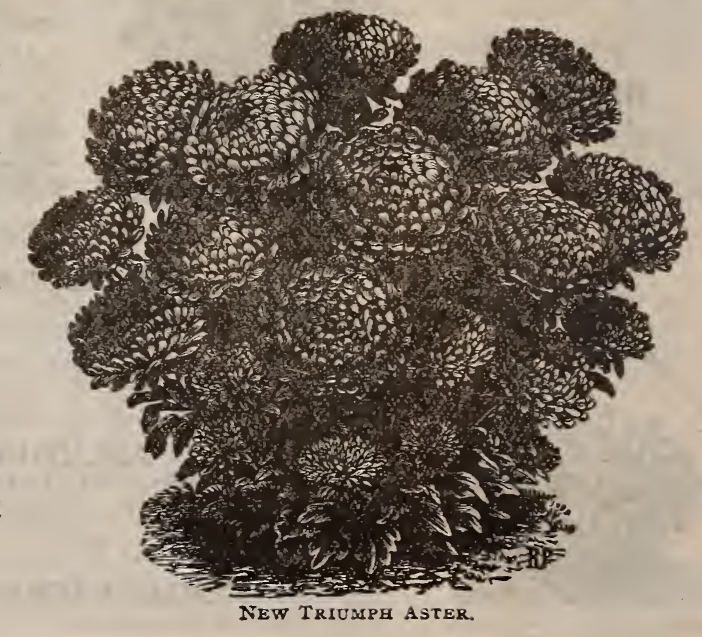




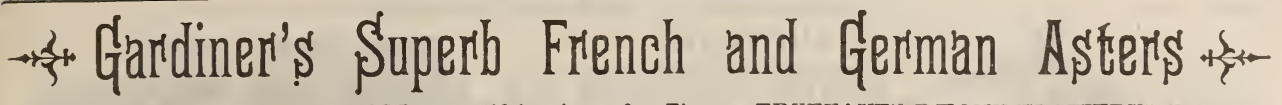

Fig. I : LARGE-FLOWERED ROSE.-Beautiful variety, of Fig. 3: TRUFFAUT'S P.EONI-FLOWERED PERFEC. branching habit; largedouble flowers of brilliant colors. Mixed TION.-This is the most perfect type of Pxony-Flowered Aster colors, pkt. Ioc. Oz. $\$ 3.00$; dark scarlet (new), pkt. $15 \mathrm{c}$, $02 . \$ 4.00$. in cultivation; in habit, form, size, and color it is unrivalled. white-centred flowers, forming a beautiful contrast to the bril- Mi.xed colors, pkt. 15c., oz. $\$ 3.50$; scarlet, pkt. 15c., oz. $\$ 4.00$; liant colored outer petals. Mixed colors, pkt. Ioc., oz. $\$ 3.50$.

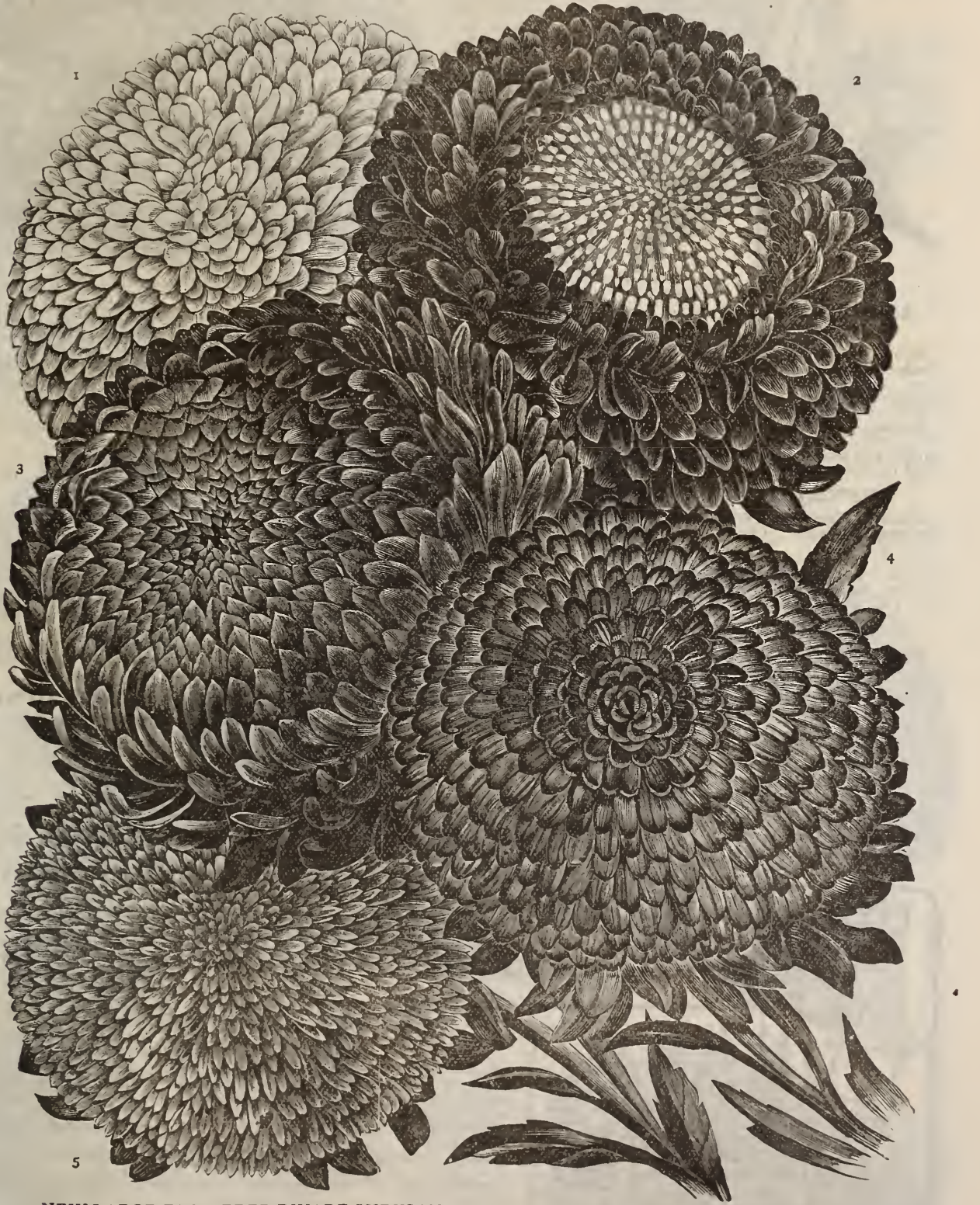

Fig. 5: NEW LARGE-FLOWERED DWARF CHRYSANTHEMUM.-Immense flowers, showy colors, compact habit. Mixed colors, pkt. Ioc., oz. $\$ 3.00$.

Fig. 4: NEW LARGE-FLOWERING VICTORIA.Of pyramidal form; large, brilliant flowers, beautifully imbri-
cated : the handsomest Aster in cultivation. Our strain is extra fine. Mixed colors, pkt. 10c. Oz \&3.50: pure white, pkt. I5c., oz. DWARF VICTORIA.-Resembles the Victoria, except in $\$$ fine. Mixed colors, pkt. 10c., Oz. \$3.50; pure white, pkt. I5c., oz. height, which is only about 12 inches. The flowers are equally
as large and brilliant. Mixed colors, pkt. 10c., oz. $\$ 3.50 ;$ pure
rose, pkt. $15 \mathrm{c}$., oz. $\$ 4.00$. Needle Victoria. - Mixed colors, pkt, white, pkt. $15 \mathrm{c}$.; bright crimson, pkt. 15c.; dark scarlet, pkt. 15c. $15 \mathrm{C}$; $0 \mathrm{0z}$. $\$ 4.00$. 


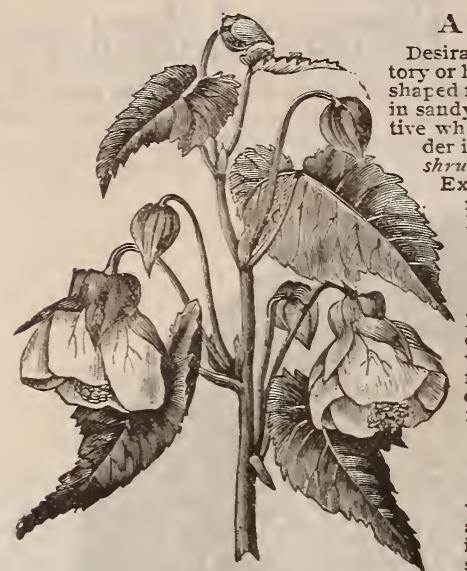

A BCtrLon.

ABUTILON.

esirable plant for corservaor house culture, with bell年 when plunged in the bor der in summer. Half-hardy Extra Fine Mixed,-From new fertilized sorts. Pkt. 25c.

ACHILLEA. Ptarmica, fi. pl.dy, herbaceous plant, with double white flowers; splendid for roc.

\section{ADONIS.}

Handsome plants with showy flowers, and of easy culture in any soil. Seed should be sownearly.
Astivalis (Flos

ARISTOLOCHIA

(Dutchman's Pipe).

Sipho. - A splendid hardy climber for covering walls, treilises, etc. Flowers brownishpurple; leaves large and glossy. Pl. $30 \mathrm{ft}$. Ploc.

Elegans.-An elegant new variety, with flowers of a dark great profusion. Pkt. 25c.

ASPERULA.

Odorata (Woodruff).-White fragrant. Perennial. I ft. Pkt. 5c., oz. \$r.oo.

Azurea Setosa.-Blue; very beautiful and fragrant; grows well in shady places. Annual. I ft. Pkt. 5c., oz. $40 \mathrm{C}$.

\section{ARABIS.}

Alpina.-An early, spring. fiuwering, hardy herbaceous plant. Excellent for borders or rock-work. Pure white. Height, $\exists$ in. Pkt. 5c., Oz. \$1.0J.

\section{ANTIGONON}

(Mexican Mountain Rose). A beautiful climber with large clusters of scarlet flowers; splendid rich shade and borne freely. Grand perennial climber for the greenhouse. Perfectly hardy

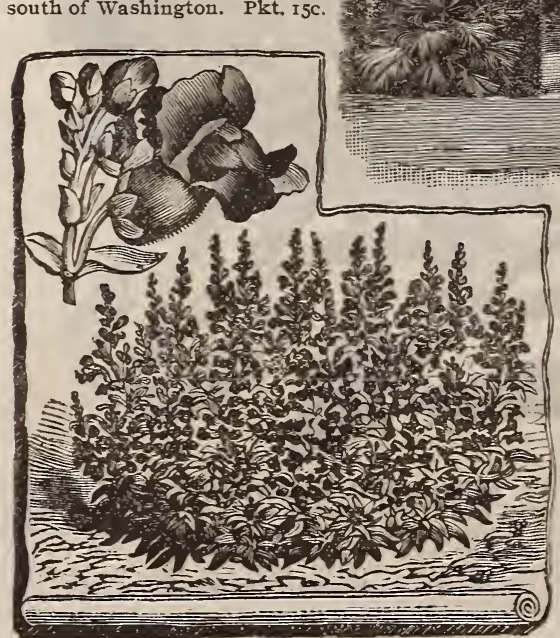

ANTIRRHINOM (SNAP DRAGON)

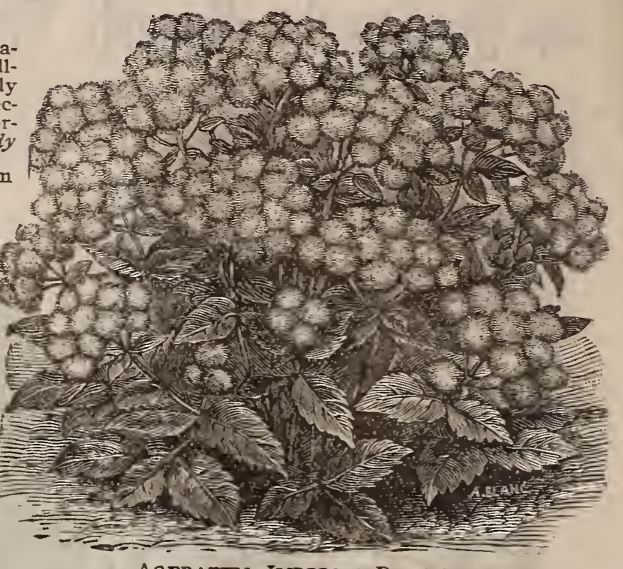

AGERATUM, IMPERIAL DWARF.

Vernalis.-Yellow. Peren nial. I tt. Pkt. $5 \mathrm{c}$, oz. $50 \mathrm{c}$. Annual. Ift. Pkt.5c., Oz. 5oc.

AGERATUM.

Fine plants for massing outside, and valuable for winter blooming in the house. Prized by florists for cut flowers. Annuals.

Lasseauxii.-Very fine rose color. $I \frac{1}{2} \mathrm{ft}$. Pkt. $5 \mathrm{c}$. oz \$I.5o.

Mexicanum A $1 \mathrm{bum}$ White. I $1 / 2 \mathrm{ft}$. Pkt. 5c., oz Mexicanum Blue. $-I^{1 / 2} \mathrm{ft}$. Pkt. 5c., Oz. 5cc.

Mexicanum Imp'l Dwarf Dark blue. I ft. Fkt. 5c., oz.

Mexicanum linp'l Dwarf. White. If ft. Pkt. 5c., oz. $75 \mathrm{c}$ Mexicanum Little Dorritt. Azure blue ; very floriferous. Pkt. 5c., oz. \$1.50.

\section{ATIPELOPSIS}

(Boston or Japanese Ivy). A most popular, hardy vine. Rapid grower, and clings tenaciously to all stone surfaces. A great attraction on many city residences throughout the country.

Veitchii.-The true Japanese or Boston Iry. Pkt. Ix. Oz. $\$ 1.50$

\section{ANTIRRHINUM}

\section{(Snap-dragon).}

Very pretty free-flowering plants. One of the best annuals for beds and borders. Grows well in ordinary soil.

Majus, Mixed.-Fine
$2 \mathrm{ft}$. Pkt. 5c., oz. $60 \mathrm{c}$.

Nanum, Mixed.-Few blotched varieties. I ft. Pkt. $5 \mathrm{c}$, oz. $75 \mathrm{c}$. Tom Thumb.- Tery dwarf; beautiful colors. Height, 9 in. Pkt. 5c. oz. $75 \mathrm{c}$.

\section{AQUILEGIA (Columbine).}

Showr. hardy herbaceous perennials. Highly prized as border plants no luse most beautiful hardv plants in cultivation.

Californica Hybrida.-Golden-yellow; sepals and spurs red. $2 \mathrm{ft}$. Pkt. oc., oz. $\$ 2.00$

Double Carnation Striped.-Very beautiful. $2 \mathrm{ft}$. Pkt. $25 \mathrm{C}$

Chrysantha.-Golden-yellow. 2 ft. Pkt. 5c., oz. \$1.00.

Cœrulea Hybrida.-Blue and white; large and beautiful. $2 \mathrm{ft}$. Pkt. Ioc., Giandulose Vera.-Very large dark blue flowers, with pure white corolla Most beautiful. $2 \mathrm{ft}$. Pkt. $25 \mathrm{C}$.

Jell Mlostid Skinneri.-Scarlet, tipped with yellow; very fine. $2 \mathrm{ft}$. Pkt. Ioc., oz. $\$ 250$

Vervæneana Double Violet.-Tery double, dark violet flowers, and ariegated foliage: beautiful. $2 \mathrm{ft}$. Pkt. Ioc., oz. $\$ 2.00$

Single, Mixed.-Finest sorts. Pkt. 5c., oz. 5oc.

Double, Mixed.-Finest sorts. Pkt. 5c., oz. $75 \mathrm{c}$. 


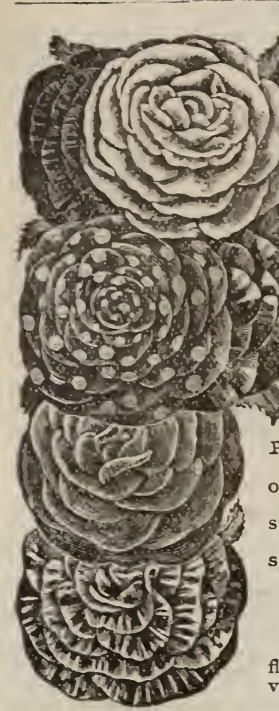

DOUBLE BALSAM.

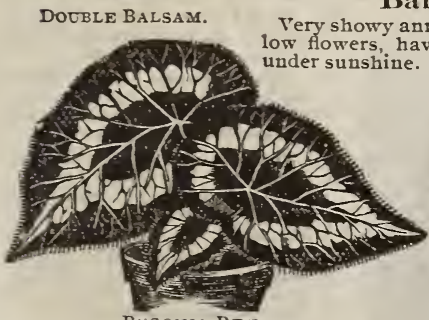

Begonia Rex. These are the popular ornamental-leaved some white, some blue; beauvarieties so popular as pot plants for all tiful for pot culture and bedkinds of decoration. The foliage is particularly striking and handsome. Pkt. $50 c$.

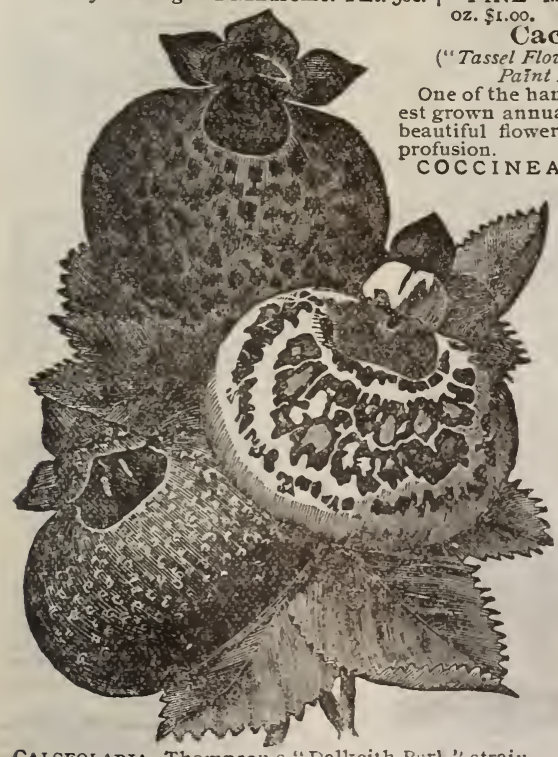

Calceolaria. Thomnson s "Dallzeith Parh" strain. z. SI.5O. CHOICEST MIXED. - Pkt, IOC, oz. \$1,0.

INE MIXED.-Pkt. 5c., oz. 40c.

Balloon Vine (Cardiospermum). Bartonia Aurea. Browallia.
Brow. best in light, rich loam. Height, I 8 in. FINE MIXED.-Pkt. $5 c$

Cacalia. Clower." "Flora's Paint Brush."

) 5c., oz. 50 c. oz. 5oc.

\section{DOUBLE BALS AMSS.}

Our improved strains of these popular and beautiful annuals produce their gorgeous masses of brilliaut blossoms in the greatest profusion throughout
the summer aud autumu. COVENT GARDEN WHITE-Very double; WHITE.-Very double;
unsurpassed for cutunsurpassed for cutCOVENT GARDEN, SCARLET. -PLE. IOC., COVENT GARDEN, MIXED.-Pkt. IOC. CAMELLIA - FLOWERED, WHITE.Very fine double, splendid for florists' use pkt. IOC., Oz. \$I.00, CARNATION-STRIPED.-Mixed; pkt. IOC VICTORIA, SPOTTED.-Satin white, scarlet

A charming climber: remarkable for its inA challoon

ving, a peculiar metallic lustre Very pretty for pots, baskets. and edgings, and unsurpassed for cutting. Flowers all summer

ABBREVIATA.-Deep rose. ELATA GRANDIFLORA.Blue, large flowered. Pkt. 5C,

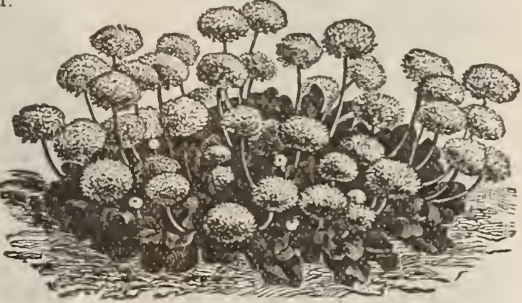

BELLIS PERENIN, FL. PL.-(English Daisy).

Bellis Perennis (Double English Daisy). As an edging for shady borders, and as pot plants, these handsome hardy perenuials are unsurpassed The strains we offer are remarkable for the size and doubleness of their flowers, and much superior to .

DOUBLE WHITE.-Pure white. Very double. lit. I5C. 02 . 55 .

DOUBLE RED.-Fine bright red. Pkt. 15c; oz. DOUBLE ROSE.-Dark rose; extra. Pkt. I5c. DOUBLE LONGFELLOW.- Rose; new and DOUBLE EXTRA CHOICE MIXED.-Pkt. $15 \mathrm{C}$. oz. $\$ 5.00$.

Fine mixed. -4 to $8 \mathrm{ft}$. Pkt. $5 \mathrm{c}$, , oz. $50 \mathrm{c}$.

Crozy's new mixed.-A remarkable new race handsome flowers and foliage. Pkt. I5C. 0z. $\$ 3.00$.

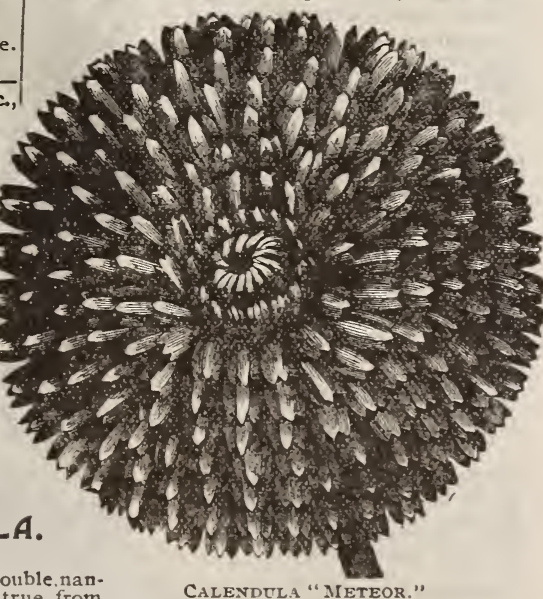
een color, comes true from seed. Pkt. 5C., Oz. $40 \mathrm{C}$ light range-striped. rkt. 5C.. oz. $40 \mathrm{C}$ PRINCE OF OR ANGE. Darker orange than "Mleteor." A fine variety. Pkt. $5 \mathrm{c} .$, oz. $40 \mathrm{C}$
SUPERBA.-Double, rich yel ow. dark-eve. Pkt. $5 \mathrm{C}$, , oz. $40 \mathrm{C}$.

\section{Campanula.}

(Canterbury Bell, Bell Flower.) Perennial sorts mixed.-Pkt.

Annual sorts mixed.-Pkt. $5 \mathrm{c}$.

\section{Calceolaria.}

Tender green-house perennial magnificently colored flowers. Thompson's "Dalkeith Park" Strain.-I'nsurpassed for richness and variety. Plt. 5oc.

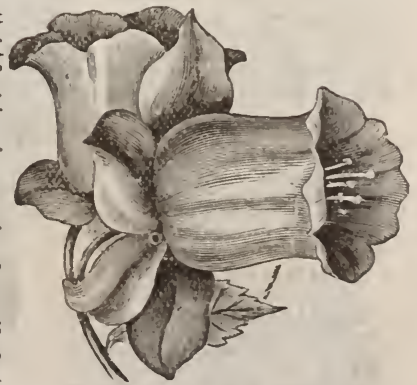

Campaxela (Canterbury Bell). 
A class of very handsome hardy perennials, remarkable A very valuable and interesting genus, remarkable for for freedom of bloom and ease of culture. Excellent sub- the showy free-flowering habit of some of its members, and jects for drying for everlasting flowers. Succed in any the beautiful silvery foliage of others. Centaurea cyanus, the ordinary garden soil.

Coerulea.-Blue. Two feet. Packet 5 cents, ounce 50 cents. feet. Packet 5 cts., ounce 50 cts.

\section{CASTOR OIL PLANT.-See} Ricinus.

CATCHFLY.-See Silene Armeria.

CELOSIA (Cockscomb).

Magnificent free flowering, graceful growing plants, producing, in the greatest profusion, their beautiful flowers in combs and feathery spikes. Seed should besown early, and planted out in June, in light, rich soil. Grown in pots they are one of the most elegant plants for conservatory decoration. Annuals.

Cristata nana mixed.-A choice mixture of the newest dwarf crested varieties, embracing the most brilliant colors. One foot. Packet 10 cents, ounce $\$ 2.00$.

Cristata nana, "Glasgow Prize."-A splendid distinct dwarf variety, with dark foliage and imson combs. One

Cristata nana Empress. Cristata nama Empress. A large and effective variety with bright-crimson combs and 15 cents, ounce $\$ 5.00$.

Huttont.-A beautiful variety with dark foliage. Two feet

Packet 15 cents, ounce $\$ 2.50$.

Japonica.-A beautiful class with delicately-cut combs, like ruffled lace, and of the most brilliant and charming colors. Two ft. Packet 10c., ounce $\$ 1.50$.

Pyramidal!s plumosa mixed.-Feathery spikes, violet, gold, and crimson, very fine. Three feet. Packet $5 \mathrm{cts}$., ounce 75 cents.

\section{CENTRANTHUS.}

Macrosiphon nanns mixed. Effective free-flowering plants of neat, compact habit. Excellent for ribbons or beds, and growing well in ordinary garden soil. Annuals. 11/2 feet. Packet 5 cents, ounce 50 cents.

\section{CERAstrium (Snow in} Summer).

Biebersteini.-Silver-leaved, plant admirably adapted for edgings, rock-work, etc. Peren-
nial. Height 3 inches. Packet 10 cents, ounce $\$ 1.50$.

\section{CHAMAPEUCE (Fish-bone Thistle).}

Diacantha.-An ornamental silvery-foliaged plant with elegantly cut foliage, very fine. Packet 5 cents, ounce 75 cents.

CHAEMEROPS (Palm).

Excelsa.-One of the finest palms for decorative purposes, with handsome spreading fanshaped leaves. Perennial. Height two feet. Packet 25 cts.

\section{CHERIRA NTHUS}

(Virginian Stock).

Maritimus. - Handsome free-flowering, hardy annual splendid for edgings. Height Glx inches. Red, white, Crimson King, and Fairy Queen. Each, packet 5 cents, ounce 50 cents.

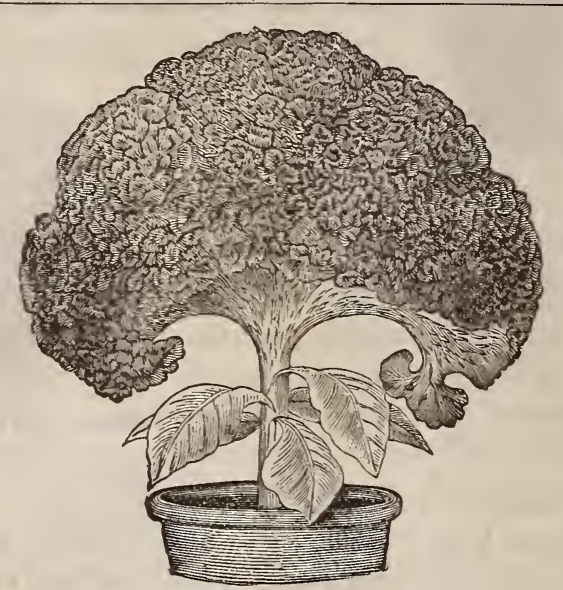

Celosia "Glasgow Prize" (Cockscomb).

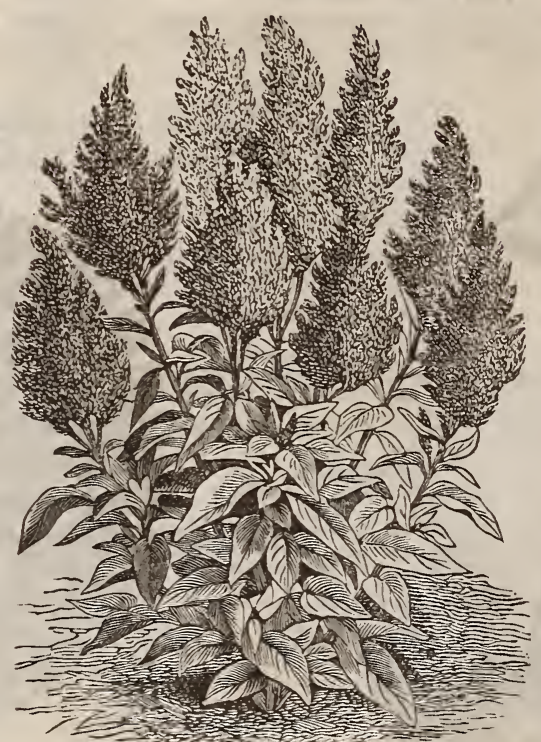

Celosia Pyramidalis Plumosa.

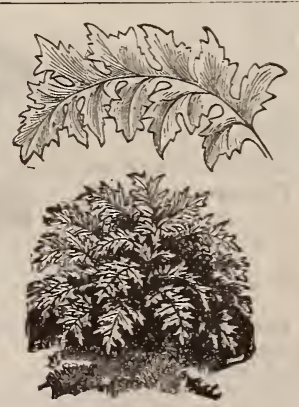

Centatrea CANDIDISSIMA.

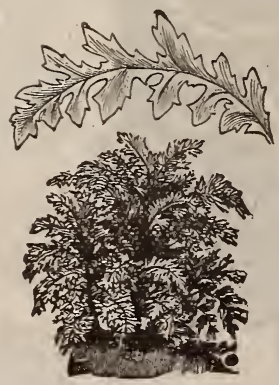

Centaurea "Bachelor's Button," C. moschata, the "Sweet Sultan," and C. americana the "Basket Flower," are among our mos valuable plants for bedding florists for cut flowers. C. mentei, candidissima menter, candidissima, an very-leaved sorts, and gener ally known as "Dusty Millers" -unsurpassed for ribbon borders. Succeed well in ordinary garden soil.

Americana. - Lilac-purple, showy, Annual. Two feet. Packet 5 cents, ounce 75 cents. Candidissima.-Silver leaves broadest and whitest of all the silvery sorts. Half-hardy perennial. One foot. Packet 10 cents, ounce $\$ 6.00$.

Clemente 1.- Silver leaves, finely cut and very white. Half-hardy perennial. One foot. Packet 10 cents, ounce $\$ 2.00$.

Cyanus mixed (Bachelor's Button).-Annual. Two feet. Packet 5 cents, ounce 40 cents. Cyanus Emperor Willtam. Very dark-blue, the finest of all the "Bachelor Buttons" Depressa.-Blue, with red center. Annual. One ft. Packet 5 cents, ounce 40 cents.

Gymnocarpa (Dusty Miller) Silvery foliage, very graceful. Half-hardy perennial. One foot. Packet 10 cents, ounce $\$ 1.50$.

Moschata (Sweet Sultan).Splendid. Annual. Two feet. Blue, white, purple, and mixed. Each, packet 5 cents, ounce 50 cents.

Saureolens ( Yellow Srweet Sultin).-Excellent for cut flowers. Annual. Two ft. Pkt. 5 cents, ounce 60 cents.

\section{CHEIRANTHCS ANNUUS.} (See Stock.)

\section{CHELONE.}

Barbata Torreyl.-Pentste. mon-like plant, with long racemes of handsome scarlet flowers, singularly benutiful. Perennial. Height two feet. Packet 5 cents, ounce 75 cents.

CH'ONODOXA (Glory of the Snow).

Lucllize.-Produces, on every stem, twelve to sixteen lovely sky-blue flowers, with a conspicuous white centre. Useful for pots, and can be used with charming effect in edging, massing, or rockwork. But bous perennials.
inches. Packet 25 cents.

CHLORA.

Grandifiora.-A very pretty plant, with brilliant yellow Height 1 foot. Packet 10 cents, ounce $\$ 1.50$.

\section{CLEMATIS.}

Rapid-growing, free-flowering climbers, admirably adapted for covering verandas, trellises, arbors, etc. The seeds require a considerable time to germinate. Hardy perennials.

Jackman's New Hybrids. Saved from Mr Jackman's celebrated collection. Packet 15 cents. 
CHRTSA NTHEMTM.

The annual varieties of the Chrysanthemum are among the most show $y$ and effect

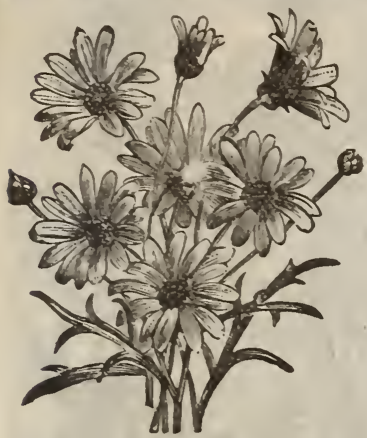

Chrysaytheycy Fretescexs (Paris Daisy).

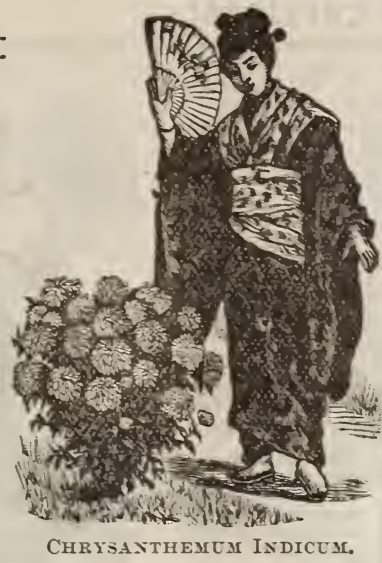

of seed is saved from a very flne prize collection comprising all the different unqualified satisfaction. Packet $25 \mathrm{cts}$ Inodornm double white.-A perennial sort flowering the first season

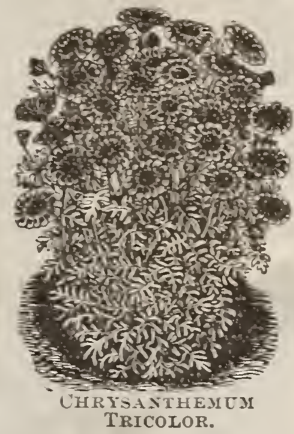

1ve of our garden favorites. They are easily grown in or- from seed and producing fine double white flowers, excel. dinary garden soil, and will bloom profusely all summer, lent for bouquets. Packet 10 cents, ounce $\$ 2.00$.

giving an abundant supply of cut fiowers, and they are also

useful for pot plants during the winter. Indicum, the well-

CINERARIA.

known Chinese, Japanese, and Pompon Chrysanthemums

The Cineraria is one of our niost popular plants; the (aking elegant subjects for conservo best in equal parts of rich loam a

Annual. $1 \frac{1}{2}$ feet. Pkt. 5c., oz. $50 \mathrm{c}$.

Tricolor burridgeanum.-Single white with crimson band and yellow center. Annual. $11 / 2$ feet. Packet 5 cents, ounce 50 cents.

T r i c o 1 or r Dunets, Double White and Double Fellow.-Free flowering. Annual. $11 /$ feet. Each packet 5 cents, ounce 50 cents.

Tricolor Eclipse.-Single golden yellow, dark brown disk and purple ring. Annual. $1 \frac{1}{2}$ feet. Packet

cents, ounce $\$ 1.00$.

Feather.-New golden leaved rariety; single white rings and dark center. 4 nnual. 11/\% feet. Packet 5 cents, ounce $\$ 1.50$. Tricolor Lord Beaconsfield.Single crimson maroon edged with gold. Annual. 11/2

Tricolor The Sultan.-Single deep crimson, gold band next the

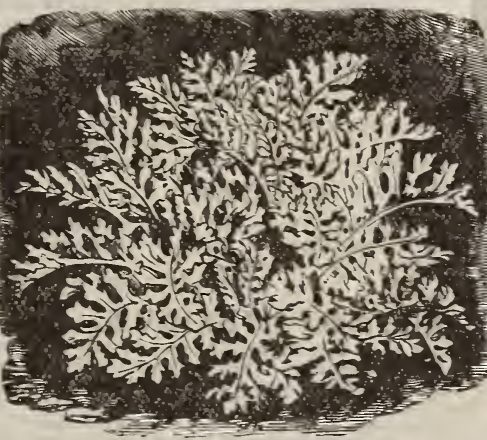

Cixeraria Caxdidissima. winter, being of neat habit and rer free flowering and producing their most brilliant flowers in great rariet y of color; while the silver leaved sorts are invaluable for edging in the summer garden being almost as much used for this purpose a the Centourea for this purpose a rea familiarly known as "Dusty Miller's." The hybrid varieties are usually sown either in September mould loam a mixture or lea off when large enough. The silver foliaged sorts are sown in February or March, and are planted out about first of June in ribbon borders or as dgings to beds. ge. 1 foot. Packet 10 cts, oz. $\$ 2.00$ Maritima.-Silver foliage very graceful. $1 \mathrm{ft}$. Packet 5c., oz. $\$ 1.00$. Whiter leaves than Maritima. Packet 5 cents, ounce $\$ 1,00$.

H y b r id a grandiflora.Tricolor purpureum,-Single deep crimson. Annual. Awarded many first premiums at the Metropolitan Exhi-

11 feet. Packet $j$ cents, ounce 50 cents.

11/ feet. Packet j cents, ounce 50 cents.

5 cents, ounce 50 cents. bitions. Packet 25 cents. did for cutting. Annuals. $11 / 2$ feet. Each, pkt. 5c., oz. 75c. CLARKIA. Frutesens (The Paris Daisy, or Irarguerite).-Golden and White. Each.

Ind i n mellknown rariety for pot and greenhouse culture; remarkable for diversity of form and color. The varieties are numerous and are divided by florists into rarious class es, "Chinese," "Pompon," "Japanese," etc. Our strain

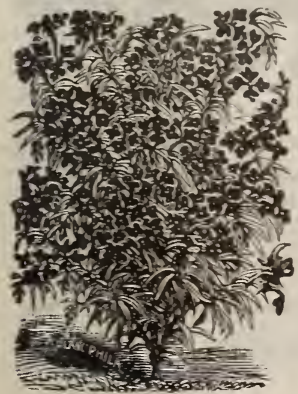

Clarkia pulchetra.

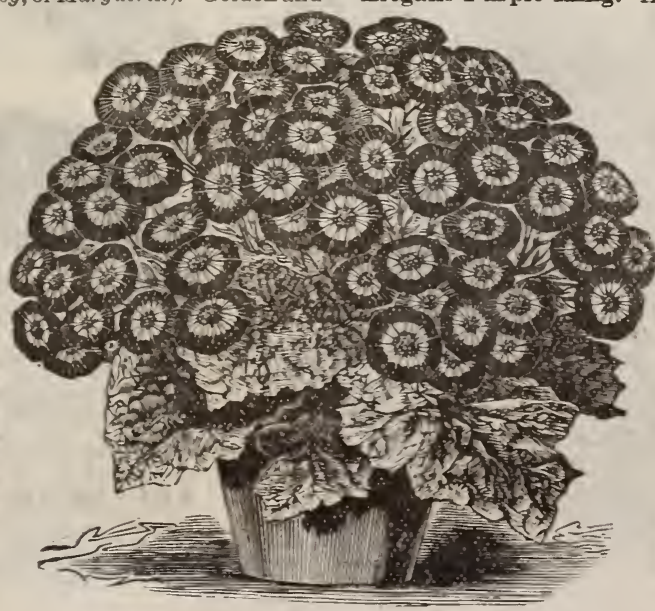

CiNerariA.-James' \& Weatherlil's Superb Strain. fine double purple rariety. Antur. Packet 5 Elegans Salmon Qucen. Similar to preceeding, but of a beautiful salmon color. Annual. Pkt. jc. ounce 50e. Elegans mixed.-Annual. Packet 5 cents. ounce 50 cts. Annual. Packet 5c., oz. $50 \mathrm{c}$.

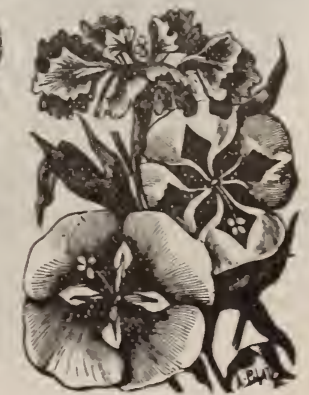

CLARKIA ELEGANS. 
COREOPSIS, OR CALLIOPSIS.

Showy genus of hardy annuals and perennials, succeeding well in ordinary garden soit.

Bicolor Mixed.-Annual. I I $1 / 2 \mathrm{ft}$. Pkt. $5 \mathrm{c}$; ; oz. $50 \mathrm{c}$

Cardaminifolia.-Dwarf, crimson. A nnual. I ft. Pkt. $5 \mathrm{c}$., oz. 50 c. Drummondi.-Yellow and.red. Annual. I I 1/2 ft. Pkt. 5c., oz. 5oc. COREOPSIS GOLDEN WAVE.-In the annual section of the Coreopsis family this is probably the most effective and beautiful. A mass of golden-yellow all summer. Pkt. Ioc., Oz. 50.

Mixed Annual Sorts.-Very choice. Pkt. 5c., oz. $50 \mathrm{c}$.

GOLDEN COREOPSIS-The Golden Coreopsis (Coreopsis lanceolata) is one of the most valuable of our summer-flowering herbaceous plants. The flowers are bright golden-yellow, beautifully fringed, and are produced freely all summer, and until late in the fall. Its freedom of bloom is remarkable, the plant being literally covered with flowers. When grown in a mass the effect is charming. Excellent for cutting; lasting well, and making up gracefully in bouquets. The root is perennial; perfectly hardy; sown early, will flower first season from seed. Pkt. 15c.

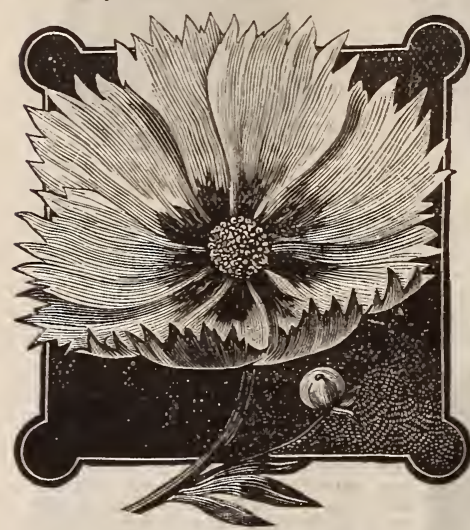

COREOPSIS Golden WAVE.
CLIANTHUS (ATSTRALIAN GLORY PEA.)

One of the most magnificent plants in cultivation, with
singularly beautiful foliage and magnificentclusters of 1ong, drooping flowers, somewhat resemb-

ling a parrot's beak. Succeeds best in loam peat, and sand mixed. Does well planted in a border of the conservatory, or will flourish

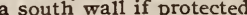
from frost. Perennial.

Dampieri (Glory Pea).-Brilliant scarlet with a black blotch in the centre. Pkt. 25c., 0z. $\$ 600$ Puniceus (Parrot's Beak).-Brilliant red spotted with white. Pkt. I5C., 0z, $\$ 4.00$.

\section{COLEYS.}

A genus of ornamental leaved plants largely

used for the decoration of beds and borders; excellent for massing. Our strain of seed is saved from a very fine collection, and will give many new and rare forms. Pkt. $25 \mathrm{c}$. COBOEA

A magnificent quick growing climber with beautiful foliage and large bell-shaped flowers. The seeds should be planted edgewise in moist earth, and water withheld until the seeds sprout. Liable to rot if watered too freely. A covering of moss or litter to prevent a too rapid evaporation of moisture is beneficial. Annual.

Scandens.-Blue, $20 \mathrm{ft}$. Pkt. Ioc., oz. \$1.00.

\section{COSMOS HYBRIDUS.}

A magnificent race of plants growing about four feet in height, and in the fall literally covered with graceful flowers resembling single Dahlias, but neater and better for cutting. They are about two inches in diameter; rose, purple, flesh, and pure white. As a cut flower for vases or personal wear their grace and beauty are unequalled. They commence to bloom in September and continue through October, the flowers bearing a slight frost remarkably. Cuttings struck in August in rich soi make fine dwarf plants covered with bloom. Potted and taken in-doors in November (like Chrysanthemums) the plants will bloom freely and last for a considerable time. Easily raised from seed and if sown early bloom the first season. Our strain is the true American Improved," and much superior to imported seed. Perennial. Mixed colors. Pkt. Ioc., Pure white, pkt. I5c.

\section{CONVOLVULUS (MORNING GLORY).}

The Morning Glory is so well known, and such a universal favorite for covering verandas, arbors, etc, that it requires no description. The dwarf covering verandas, arbors, etc., that it requires no description. The dwari
varieties of Morning Glory are, however, not quite so well known, but are

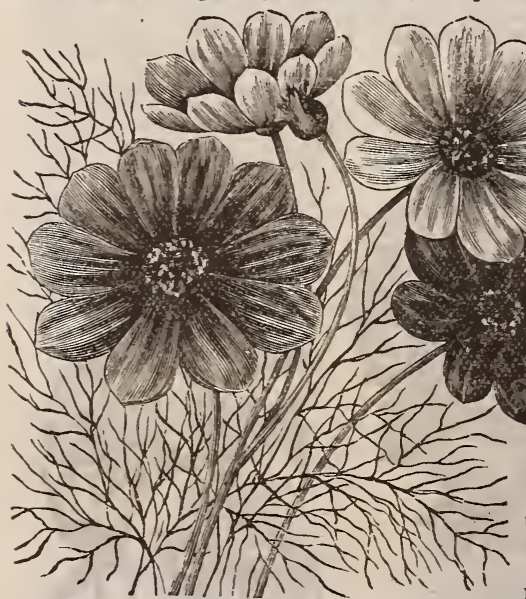

Cosmos HYBRIDEs.

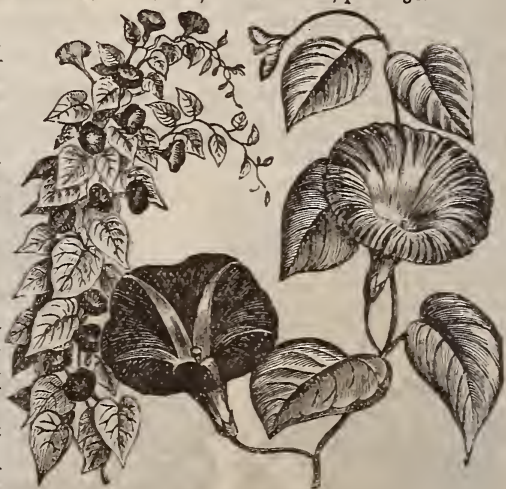

Convolvelos MajoR (Morning Glory). a mong th showiest and nuals we have. They $\mathrm{g}$ ro about a foot in height, and make excellent subjects for rib bun borders, produci, etc. rich and bri! liant and bril great profusion.

Major Fines Mixed (Morn ing Glory).best varieties. Annual. Pkt.

Mauritanicus. - Blue; beautiful for hanging baskets and vases. Perennial. Pkt. roc., Oz, zI, Co.

Minor Finest Mixed (Dwarf Morning Glory). - Saved from the best varieties. Annual. Height, I ft. Pkt, $5 \mathrm{c}, 0 \mathrm{z}, 20 \mathrm{c}, \mathrm{I} / 41 \mathrm{~b} .65 \mathrm{c} ., 1 \mathrm{~b} . \$ 2.00$

\section{COLLINSIA.}

An exceedingly pretty free-flowering class of annuals from California. Fine for beds or ribbon borders.

Finest mixed.-Saved from the best sorts. I ft. Pkt. 5c., oz., $50 \mathrm{c}$ 
(4) $A$ CN These elegant green-house perennials have 1 LILI. been vastly improved of late years - the giganvance in form, color, and substance, in addition to great size of flower and freedom of bloom. Our strain is selected from the improved English sorts brought ont by James, Thompson, Clark and other celebrated market growers, and is conceded to be unsurpassed.

CYCLAMEN PERSICUM (Wiggen's strain).-A very superior strain of the Pincum-not the girantenm). Mixed colors. I5C. pkt.

CYCLAMEN PERSICUM GIGANTEUM - A magnificent strain; extra Selected, Mixed colors. 25c, plit.

Vote.-Cyclamen seeds sown early will bloom following winter. We can supply

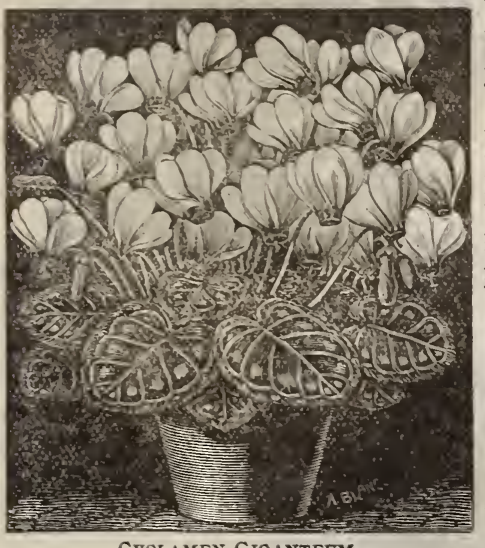

CrCLAMEX GIGANTEUM.

DELPHINIUM.

\section{(LARKSPUR.)}

Very showy herbaceous plants, with finely-cut follage and handsome flowers in different shades of blue, purple, and white. For large beds on lawns or masses and mixed borders they are unsurpassed. The taller growing varieties are also excellent for a sunny situation.

Elatum (Bec Larkspur).-Blue; 5 ft. Pkt. 5c., 0z.5oc. Formosum.-Dark blue. Perennial. $2 \mathrm{ft}$. Pl-t. 5c.,

Oz. \$t.00, crimson. Perennial. $2 \mathrm{ft}$. Pkt, Ioc., oz. \$3.00.

Hybridum, fi pl.-Saved from a choice collection

of double-flowered perennial sorts. Pkt. I5c.
Double Dwarf Rocket (Larkspur).-Various colors. Annual. I ft. Pkt. 5c., oz. 40c.

Double Tall Rocket (Larkspur),-Tarious colors.

Annual. I1/2ft. Pkt. 5C., 0z. \$1.00.

Double Tall Branching (Larkspur)

Double Dwarf $\mathrm{C}^{12} \mathrm{ft}$. Pkt. 5c., Oz. 40c. colors Annual I Pkt, IOC, 0.$\$ 2.00$.

Bismarck (Larkspur). - A beautiful red striped variety. Annual. I ft. PLt. 5C., oz. 75c.

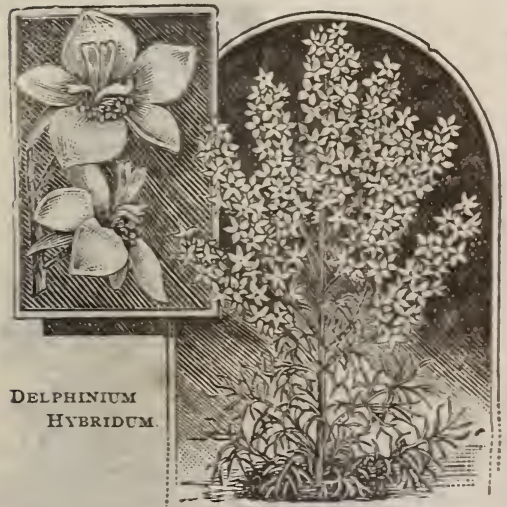

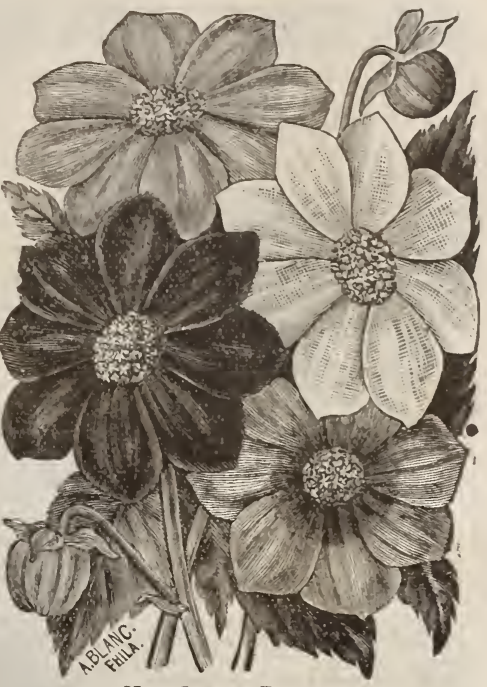

NeW SiNgle DahLias.

Double Large-Flowering Mixed.-Saved from a choice collection. Pkt. Ioc., oz. $\$ 3.00$. Double Dwarf, Mixed.Double Liliput. $-5 \mathrm{~m}$ a 11 fowering variety, of dwar habit. Excellent for bedding.
Plt. Ioc., oz. $\$ 4.00$.

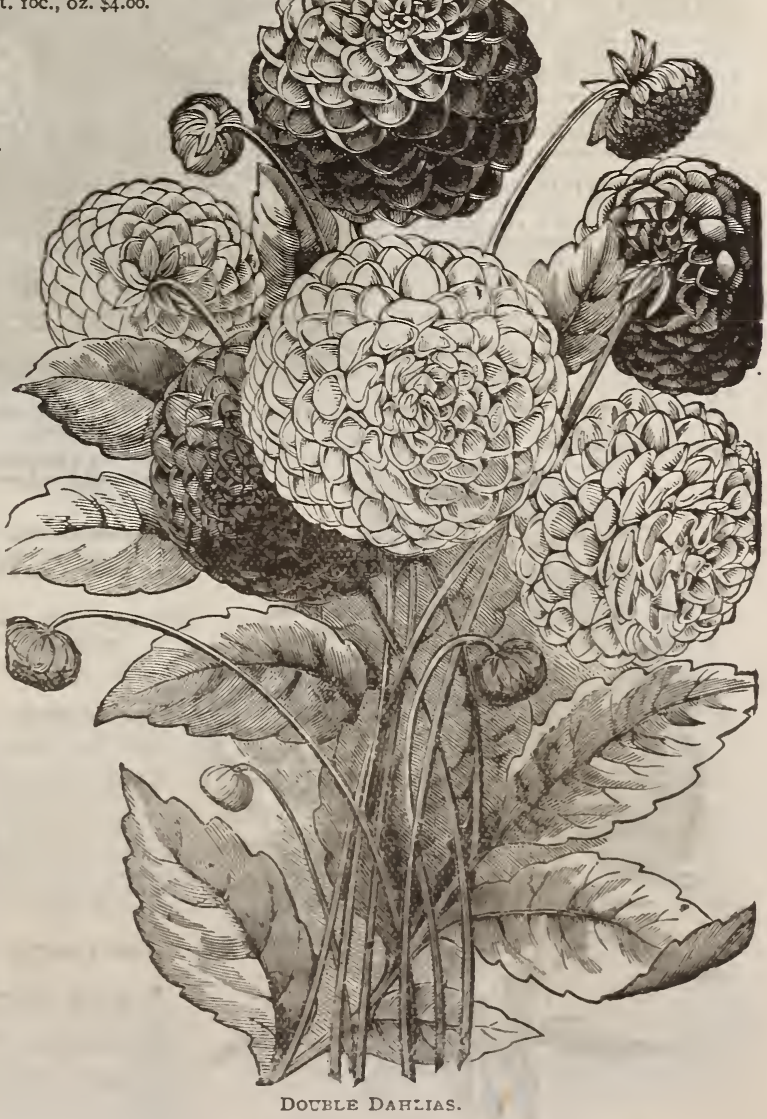


DIANTHUS (Pink.)

A truly beautiful genus, containing some of the most prized flowers we possess. The flowers are brilliant, showy, and fragrant; the foliage always bright, as green and as vivid in winter as summer. The annual and biennial varieties merely require sowing in the open border, where they will grow and flower freely. The perennial varieties inaybe

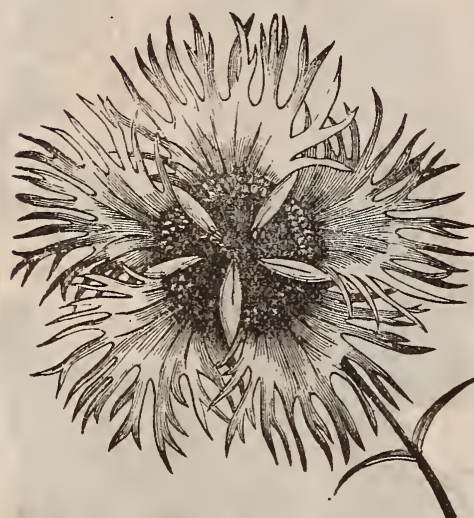

Dianthus Heduewigr (Single Fringed). sown in spring in gentle heat. The Carnations rebourhs avd leaves of spuce boughs and leaves during liams are generally sown in August or September but may also be sown in spring.

Barbatus singlemixed (Sweet William).-Hardy 5 cents, ounce 50 cents.

Barbatus dowble mixed.-Fine strain. Barbatus, Hunt's rearis, perrection a rery strain of the auricula-eyed sweet William. Packet cents, ounce 75 cents. Caryophyllus (Carna tion).-Choicest mixed saved from stage flowers a very choice strain of carnations, pinks, and picotees. Half-hardy cnnial. Packet 50 cents.

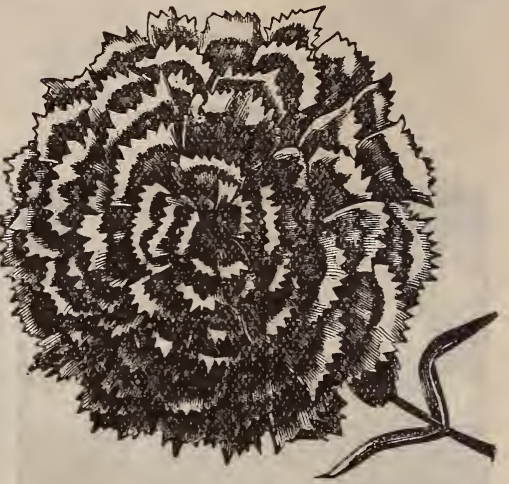

Dianthes Heddewigi, FL. PL.

Caryophyllus (Carnation).Double finest, mixed from open ground flowers. Packet 25 cents. Caryophyllus (Carnation).Double fine, mixed from open ginund flowers. Packet 10 cents,

Caryophyllus (Carnation) Perpetual or Tree.-Choicest double mixed. Packet 50 cents. Chinemsis (China pink). - A splendid mixture of double fiowering varieties. Annual. One foot.

Cimmabarinus.-Hardy alpin perennial, with lustrous scarlet flowers. One foot. Packet 25 cents.

Hed dewion (Diadem pink). Single mixec (Diadem pinnial. One font. Packet 5 cts, oz. $\$ 1.50$ Heddewigi Crimson-lake. Packet 5 cents, ounce $\$ 1.50$.

Heddewigi Crimson Belle. Beàutifully marbled. Packet cents, ounce $\$ 1.50$.

Heddevigi Diadematus fi. pl. Double mixed. Packet 10 cents, $\$ 3.00$

Heddewigi Laciniatus. Double fringed mixed. Packet 5 cents, ounce $\$ 1.50$.
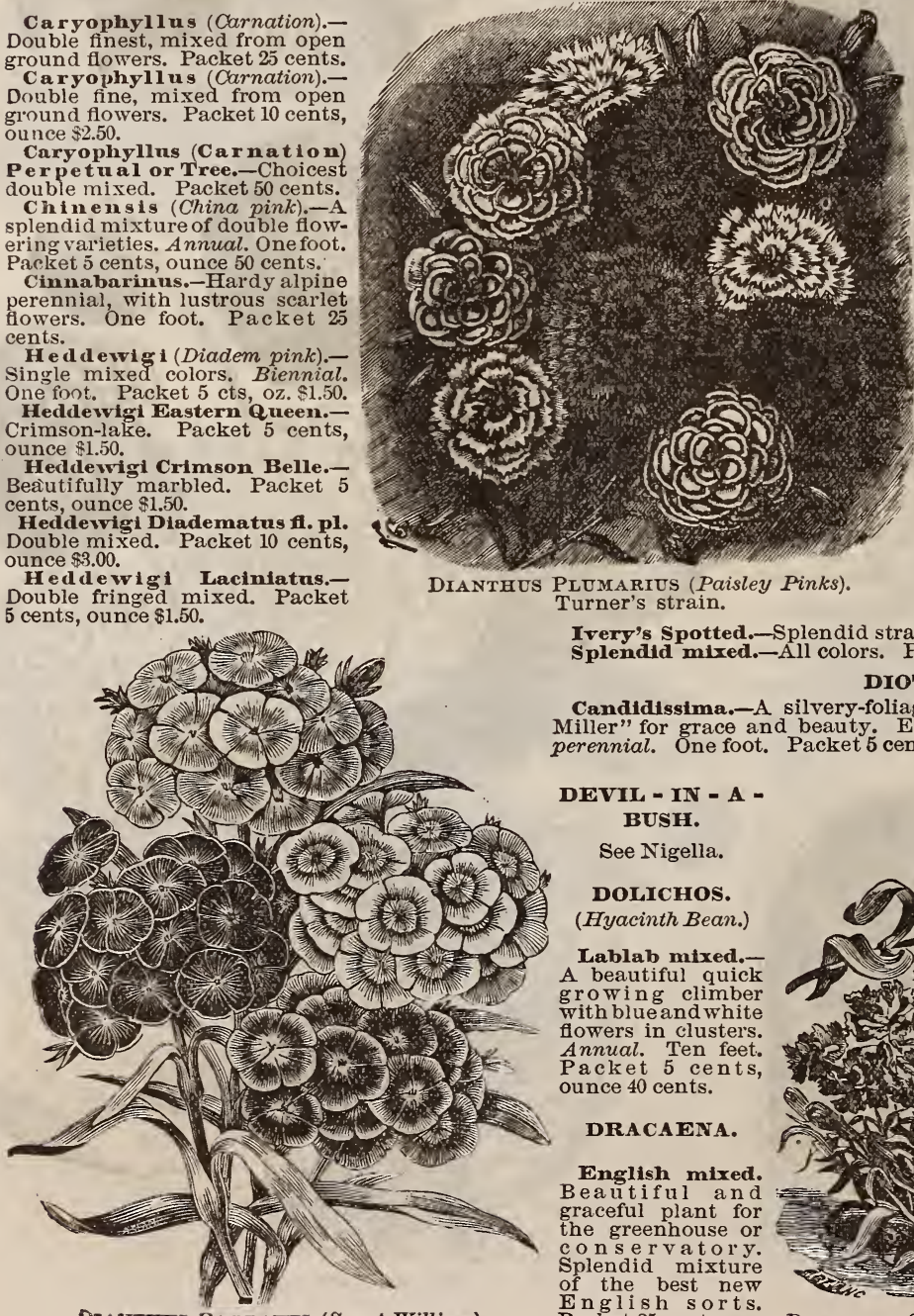

Imperialis (Imperial pink).Double mixed. Annual. Packet 5 cents, ounce 75 cents.

Plumarias (Hardy Garden Pink).-Single fringed, dark centers. Hardy perennial. Packet cents, ounce 50 cents.

Plumarias 1. 1. pl. (Double Gar den Pink). - Finest double, mixed colors. Packet 10 cents, ounce

Plu ma ri us (Paisley or Show Pink).-Saved from Mr. Turner's choicest double varieties. Very scarce. Packet 50 cents.

DICTAMNUS (Fraxinella). Very ornamental plants, worthy of a place in every fiower border. The leaves, when rubbed, emit an odor like lemon peel, Familiarly known as "Gas Plant" Excel lent for bees. Hardy perennial. 2 feet. Red and white. Each, packet 5 cents, ounce $\$ 1.00$.

DIGTTALIS (Foxglove).

Exceedingly showy plants for shrubbery, borders, etc. Easily cultivated in ordinary garden soil. Hardy perennials. 3 feet.

Gloxinime spotted. Packet $5 \mathrm{c}$., ounce $50 \mathrm{c}$ Ivery's Spotted.-Splendid strain. Packet 5 cents, ounce 50 cents. Splendid mixed.-All colors. Packet 5 cents, ounce 50 cents.

DIOTIS.

Candidissima.-A silvery-foliaged plant, rivaling the "Dusty Miller" for grace and beauty. Excellent for edgings. Half-hardy perennial. One foot. Packet 5 cents, ounce $\$ 1.00$.

DEVIL - IN - A BUSH.

See Nigella.

Dourchos. (Hyacinth Bean.)

Lablab mixed. A beautiful quick growing climber with blueand whit flowers in clusters. Annual. Ten feet. Packet 5 cents, ounce 40 cents.

\section{DRACAENA.}

English mixed. Beautiful and graceful plant for the greenhouse conservatory. splendid mixture of the best new Packet 25 cents.

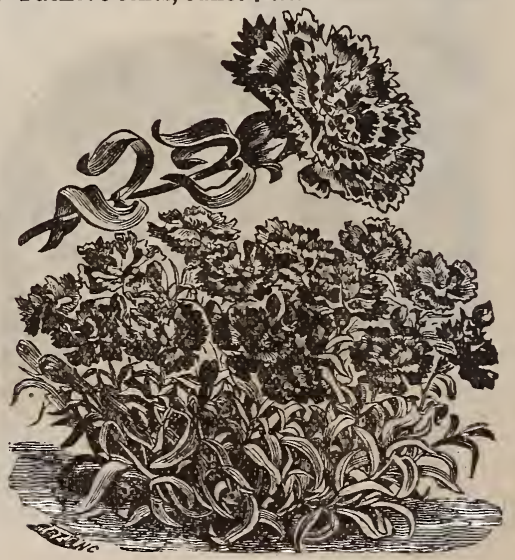

Dianthus Chinensis FL. PL. (China Pinks). 


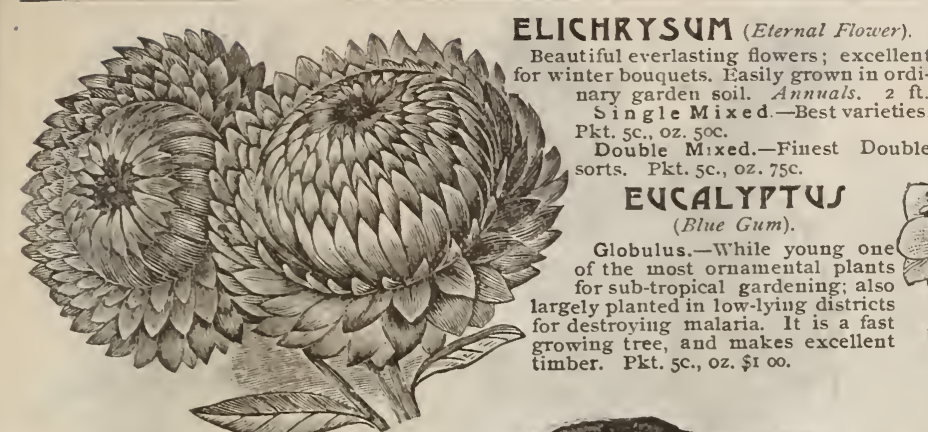

ELICHRYSUM (Eternal Flower).

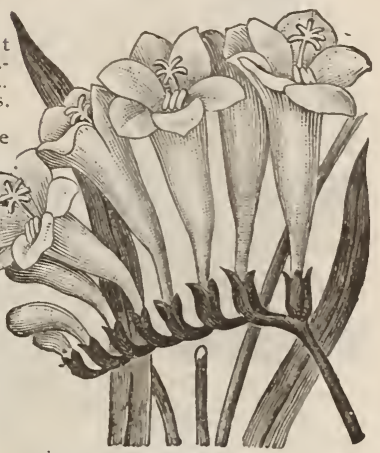

ELICHRYSUM DOUBLE.

ESCHSCHOLTZIA

Er California Popp

a nu uals with bright

showy flowers, blooming

freely" all summer. Ex-

or rockwork. Height,

I ft.

Californica. - Yellow white, rose, carmine and mixed. Each, pkt. 5c. oz. 5 oc.

Crocea. - Orange and striped. Each, plt. 5c.

oz. $40 \mathrm{c}$. yellow and white. Each kt. $5 \mathrm{c}$, oz. $75 \mathrm{c}$

sich range inside; outside brilliant scarlet. Pkt. c.. Oz $75 \mathrm{c}$.

Tenuifolia.-Y $1110 \mathrm{w}$; fine leaved. Pkt. $5 c$., oz. $40 c$

Finest $\mathrm{mix}$ ed.-Pkt.

\section{GLOXINIA.}

These are most charming plants for the parlor or conservatory, being almost ninsurpassed for ness in coloring. There are few plants that have been so much improved of late years as this. Formerly they had a drooping habit, which detracted considerably from their beauty as compared with the gor compared - colored. erect geously -colored, erect, varieties which we $110 \mathrm{w}$

possess. If sown under glass early in spring they will flower the following spring

New French Hybrids. - Tigered and spotted, extra choice; saved from a most beautiful collection. Plat, $5 \circ$.

Crassifolia.-A magnificent strain of large-flowering, erect and horizontal blooming vaneties: extra ch.

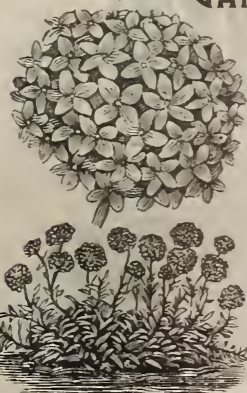

Very showy genus with ${ }^{\circ}$ brilliant flowers produced in great profusio during the summer and autumn. Lorenziana-Double mixed color spiendid new race

Picta,-Single, mixed colors. $A n$

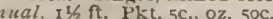

Grandifiora super large-flowering strain of the peren nial gaillardia; great improvement: splendid colors. I I $\mathrm{ft}$. Pkt. $5 \mathrm{C}$.

\section{GODETIA (SATIN FLOWER).} Lady Satin Rose.-Glossy rose rich and deep; claimed to beth rose tion Pl-t $15 \mathrm{C}$.

Lady Albemarle.-Brilliant dark crimson. Pkt. $5 \mathrm{C}$, oz. $50 \mathrm{C}$.

The Bride - White, crimson cenCIILLARDIA IORENZIANA.
UCALYPTUS

FreEzIA REFracta ALBA

FREEZIA.

This lovely South African has taken first rank among popular favorites in an incredibly short wondered at when we consider not on $1 \mathrm{y}$ the remarkable beauty and delicate fragrance of its flowers, but the ease with which it bility for and its suitabe quit = easily raised from seed which if sown in springwill make bulbs that will flower the following winter.

Refracta alba.-White: eet scented. Prt. I5c. FUCHSIA. Hybrida. - aved from a splendid collection.

\section{HELIANTHUS}

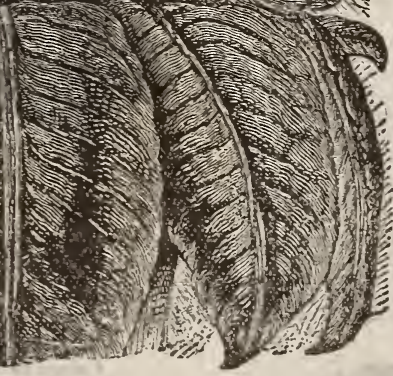

Sunflower). Old favorites, too wellknown to need any description. Excellent subin shrubbery, borders, etc. Of the easiest culNew Miniature.-A magnificent small-flowsplendid for cutting. Giant Russian.-Single, very large. $8 \mathrm{ft}$. Pkt. 5c., Oz. $25 \mathrm{C}$. small flowers. $8 \mathrm{ft}$. Pkt. 5c., oz. 5oc.

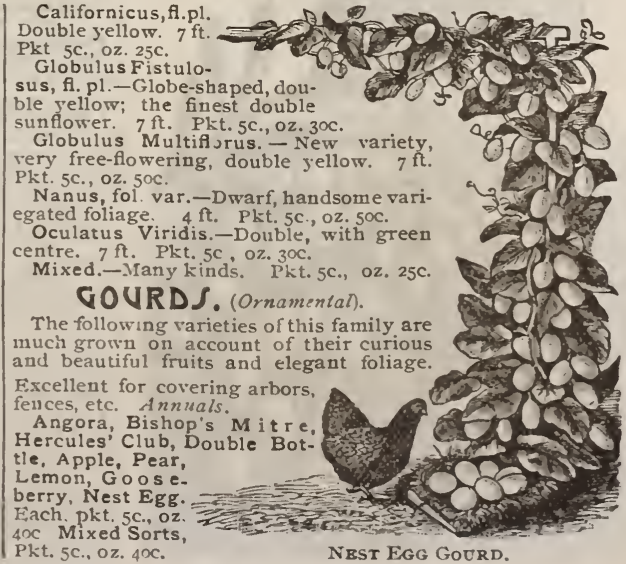




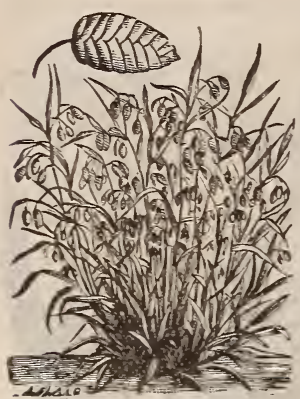

ORNAMEXTAL GRASS. BRIZA MAXIMA.
QUAKIYG GRASS."

GRASSES (Ornamental)

The following varieties of grasses are rery attractive and ornamental in beds and borders, and are largely used for

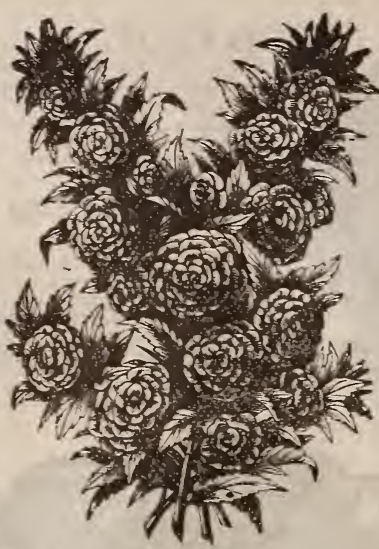

HOLLYHOCK CHATER'S SUPURB DOUBLE.

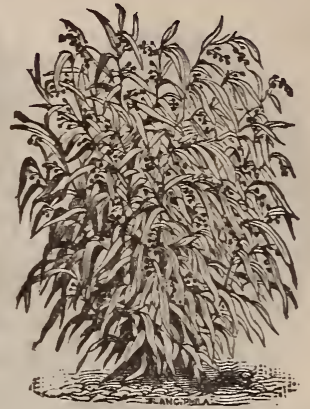

ORNAMENTAL GRASS. COIX LACHRYMA. 'JOB'S TEARS.'

Hare's Tall Grass.-See Lagurus.

Job's Tear8.-See Coix.

Lagurus oratus (Hare's Tail Grass).Elegant. Annual. One foot. Packet 5

making dried bouquets and for mixing with everlastings Stipa peumata (Feather Grass).-Splendid for bouquets. for winter decoration. Should be gathered and dried Perennial. Two feet. Packet 10 cents, ounce $\$ 1.00$.

before they are fully matured.

Sripa elegantissima.-Very graceful. Perennial. Two feet. Packet 10 cents, ounce $\$ 1.50$.

Mixed Ornamental Grasses. Many kinds. Packet 5 Agrostis nebulosa.-Feathers, graceful. Annual. 11/2
Mrixed Ormamental
cents, ounce 50 cents.

Anthoxanthum graclle.-Elegant for edgings. Annual. Collection 12 varieties, 50 cents.

Six inches. Packet 5 cents, ounce 50 cents.

Arundo comspicua (Vew Zealand Pampas Grass). Per-

HELIOTROPIUM (Heliotrope).

ennial. Eight feet. Packet 10 cents, ounce $\$ 4.00$. Finest mixed.-Favorite half-hard $\mathrm{F}$ plants for bedding Arundo Donax, rol. var.-Beautiful striped foliage. Perennial. Seren feet.

Avena sterllis (Animated Oats).-Droop-
Avent 5 cents, ounce 50 cents. ing spikes. Annual. Three feet. Packet 5 cents, ounce 50 cen ts.

Briza graclis (Quaking Grass).-Beautiful. Annual. One foot. Pkt. $5 \mathrm{c}$, oz. $40 \mathrm{c}$. Briza maximus (Large Quaking Grass). Annual. One foot. Packet 5 cts., oz. $30 \mathrm{cts}$. Bromus brizaeformis.-Elegant drooping panicles. Perennial. $11 / 2$ feet. Packet

5 cents, ounce 30 cents. of this elechryma (Job's Tears). - The seeds of this elegant variety are strung and used feet. Packet 5 cents, ounce 30 cents.

Eragrostis elegans (Love Grass).-Tery graceful. Annual. $1 \frac{1}{2}$ feet. Packet cents, ounce 50 cents.

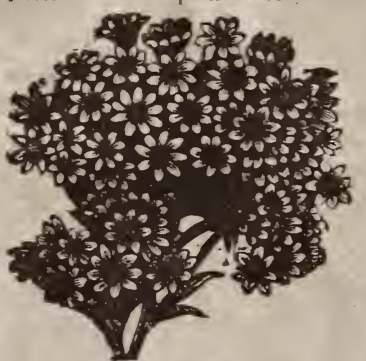

HELIPTERUM (Everlasting). and pot culture, much valued on accoun of their delicious fragrance. Succed best in a rich soil. Tender perennial. $1 \frac{1}{2}$ feet. Packet 10 cents, ounce $\$ 2.00$.

HELIPTERUM (Everlasting).

Excellent everlastings for winter bouquets. Succeed best on light, rich soil. Tender annuals. One foot. White and yellow. Each, packet 5 cents, ounce 75 cts.

\section{HOLLTHOCK.}

A Tell-known favorite; one of the stat liest and handsomest plants we possess. The new prize varieties produced by Mr. Chater have most magnificent spikes of flowers and great rariets and delicacy of color. Seed sown in July will flower the following season. Do best in a deep, dry soil, enriched with plenty of manure. Hardy biennial. Height six feet.

Erianthus Ravennae.-A noble grass fet. Packet 5 Donble Chater's Prize.-Sared from rivaled collection. Mrixed colors. Packet 25 cents, ounce Eula ta Japonica Eula ia Japonica.- - Iagnificent grass from Japan; very $\$ 5.00$. Collection of 6 colors, 70 c. Collection of 12 colors, $\$ 1.25$.
stately and unsurpassed for grouping on the lawn. Perennial. Ten feet. Packet 5 cents, ounce $\$ 1.00$

Gynerinm Argenteum (Pampas Grass).-A noble grass. Perennial. One foot. Packet 5 cents, ounce $\$ 1.00$.

IBERIS (Candytuft).

Amara.-White. Annual. One foot. Pkt. 5c., oz. 30c. Coronaria White Rocket.-Free flowering. Annual. One foot.

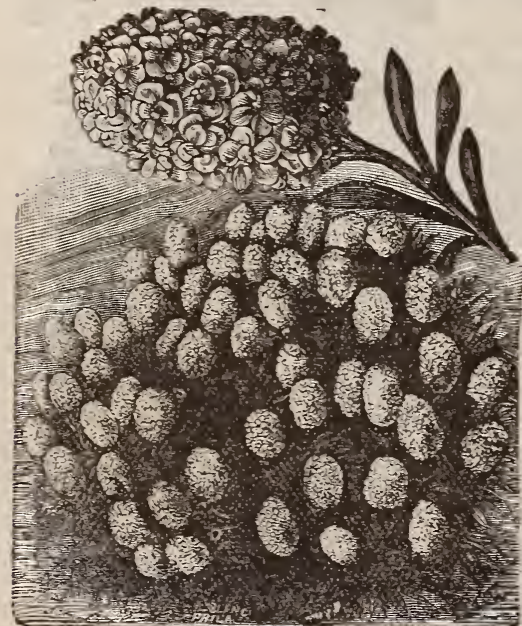

IBERIS CORONARIA (Chndytuft) EMPRESS.

Packet 5 cents, ounce 30 cents. foot. Coroma Empress. - Ner, pure

Coronaria Zirngiebels.-Very large heads, pure white. Annual. One foot. Pkt. 10c., oz. \$2. Pectinata.-White sweet-scented. $A n$ nual. One foot. Packet cents, ounce 30 cents. U m bellata. Annual. One foot. White flesh, carmine, lilaa crimson, and mixed.

Each, pkt. 5c., oz. 30c. Nana hy brtda.pact growing, very charming. Annual. Six inches. Irixed six inches, 10 , Pled Finest mixed.Annual rarieties, splendid mixture. Packet 5 cts., oz. 30 cts. Gibraltarica hybrida.-Very fine species with white flowers shading off to lilac. Perennial. One foot. Pkt. $20 \mathrm{c}$., oz. $\$ 8$. Pruiti.-Pure white, Perennial. Six inches. ORxa Mextal Grass. Gyxeridy ARgexteum. acket 10 cts., oz. $\$ 3.00$ Sempervirens.-White, very early. Perennial. $1 \mathrm{ft}$. Pkt. 5c., oz. \$1.

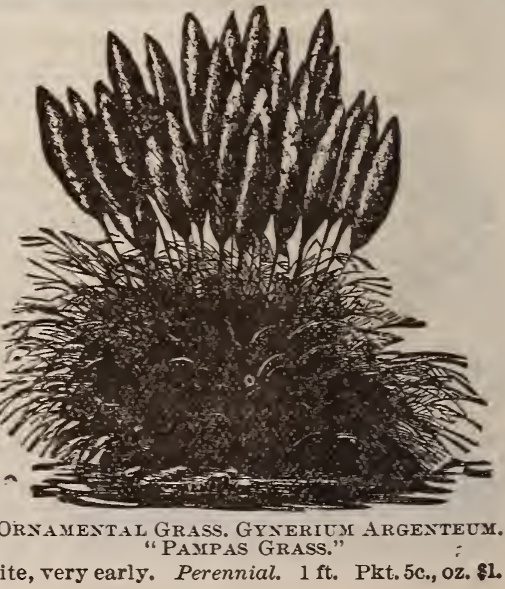




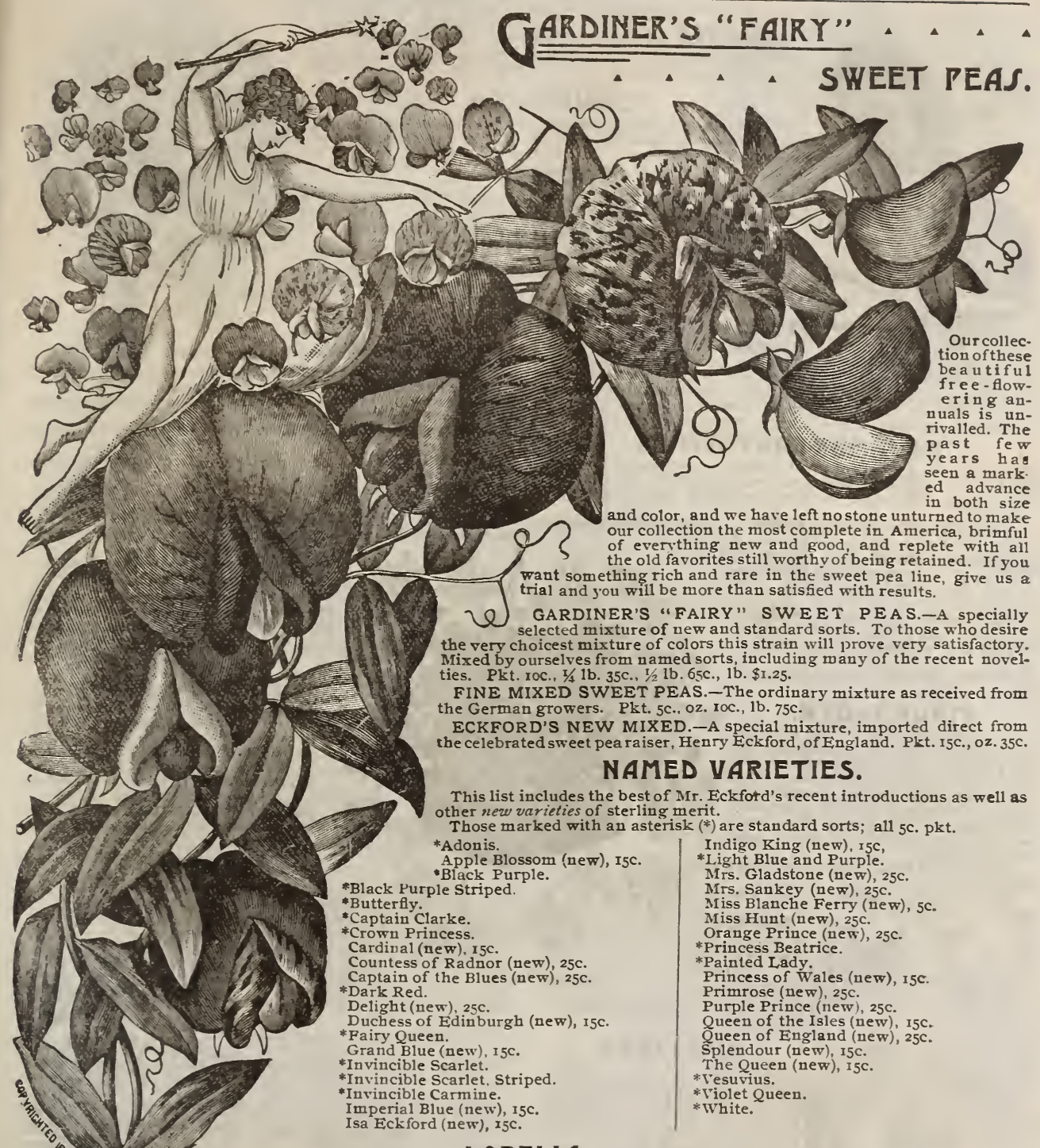

\section{LOBELIA.}

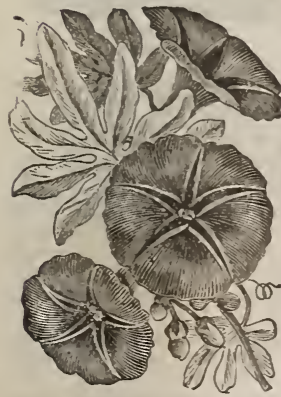

IPOMGEA.

Very interesting bedding plants; free-flowering, neat, and beautiful. Largely used for beds, edgings and baskets. Easily grown and flower the first season from seed. Start in heat. Tender perennials.

ERINUS (Gracilis). -Blue; best for hanging baskets. 6 in. Pkt. $5 \mathrm{C}$., ERINUS COMPACTA OCULATA.-Dark blue, white eye, dark

foliage: splendid. Pkt. IOC.

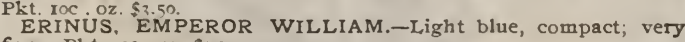
fine, Pkt. 10c., oz, $\$ 3,00$.

IPOMOEA. (CYPRESS VINE.)

Elegant twining plants, with handsome, showy flowers and beautiful foliage. Fixcellent for covering trellises, arbors, fences, etc. Annuals. ful follage. Frcellent for covering trellises.arbors, fences, etc. Annuals. QUAMOCLIT (Cypress Vine), - A favorite, well-known, clinibing whe, with graceful, arry foliage and handsome flowers. Scarlet and BONA NOX (Evening Glory).-Large, pale lilac flowers, opening

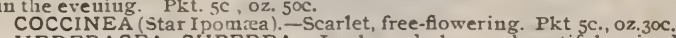
HEDERACEA SUPERBA.-Iry-leaved, large, beautiful; mixed colors. Pkt. 5c., oz. 5oc.

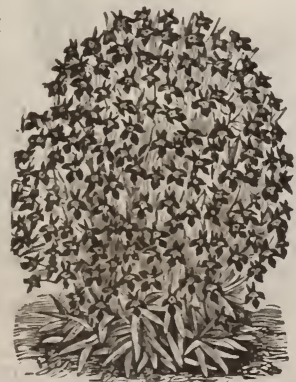

LOBRLIA ERINUS CON. PACTA OCULATA. 


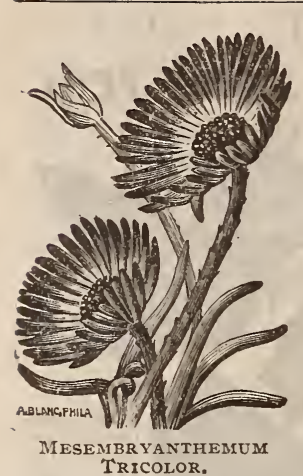

TRICOLOR.

limbing vines, and is held in this plant is unrivalled amongs for decorations of all kind. Tender perennial, succeeding best in rich soil. Start the seeds in heat. Pkt. Ioc., oz. \$2.00.

\section{MESEMBRYANTHEMUM.}

Dwarf-growing plants of great beauty, producing their starike edgings and rock-work. A light saudy soil suits them best. edgings

Annuals.

plant, with lovely variegated leaves. Pkt. I5C.

CRYSTALLINUM (Ice P lant).-

White, prized for its peculiar glistening foliage. Excellent for garnishing. 6 in.

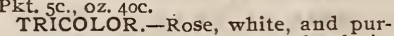
ple, dwarf; very pretty. Succeeds admirably in dry situations. 3 in. Pkt. 5 c.

FINEST MIXED.-The best varieties. Pkt. 5c., Oz. $75 \mathrm{C}$

\section{MAUR AND Y A.}

Evergreen twining plants, excellent for the greenhouse or summer garden. Very effective and ormamental for trel. lises, their large, handsome flowers fung proatest profusion. They are half-hardy perentials, flowering the first season from seed, a ud succeed bes enriched loam

BARCLAYANA.-Blue; very popula $r$. PKt. IOC., OZ. $\$ 4.00$.

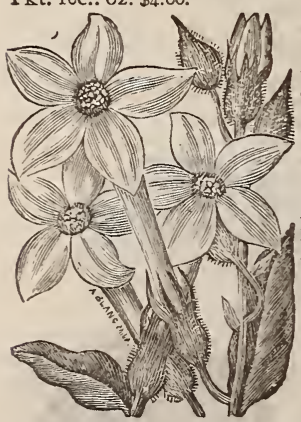

Pkt. IOC.. Oz. \$4.00. PURPUREA GR A N D IFLORA.-Purple.
$0 z . \$ 400$ ALBIFLORA. Pure white; very pretty. Pkt. Ioc. oz. $\$ 5.00$.

\section{NICOTIANA.}

AFFINIS.-Deliciously fragrant, large, white flowers; very ornamental and one of the best of recent introductions; easily grown. Excel lent either for pots or beds. Annual. I I $/ \mathrm{ft}$. Pkt. 5C., OZ. \$I.5O. SUAVEOLENS.-White, fragrant dark foliage; handsome. $3 \mathrm{ft}$. Pkt. $\$ 2.50$.
Nicotiana AfFinis.

\section{Trailing plants} very ornamental of golden-yellow color, warted, and when ripe opens, disclosing its seeds and brilliant carmine interior. Planted on rock-work, stumps of trees, etc., and allowed to ramble, the effect is very striking. Annual. Io ft.

BALSAMINA (Balsam Apple).-Pkt.5c., oz.50C. CHARANTIA (Balsam Pear).-Pkt. 5c., oz. 5oc.

\section{MUSA (ABYSSINIAN BANANA).}

ENSETE. - Magnificent foliage plant, with broad, massive leaves that grow to immense proportions. A superb plant for the lawn, only requiring to be known to become exceedingly popular. Seeds should be started early, and ft
Ioc. MOMORDICA. with curious and

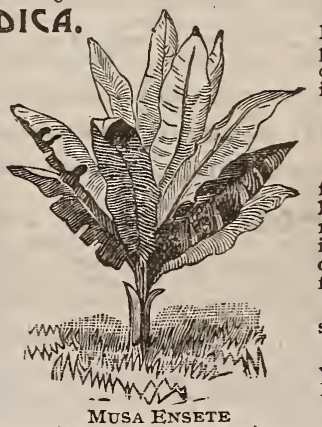

MUSA ENSETE

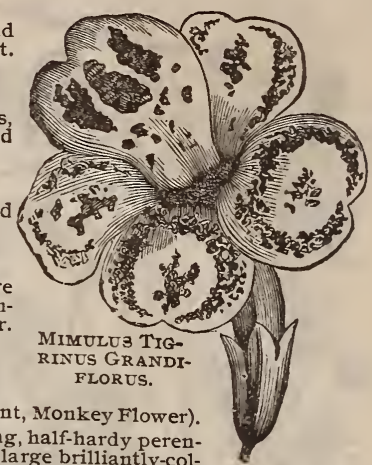

Magnificent free-flowering, half-hardy peren-

ored flowers. They succeed best in moist, shady situations, and ill bloom the first year from seed.

CARDINALIS PERFECTION.-Deep red; new, very fine. CUPREUS DUPLEX (Hose-in-Hose).-Double corolla; splenPkt. IOC.

MOSCHATUS (Musk Plant).-Yellow. I I $/ 2 \mathrm{ft}$. Pkt. Ioc., oz. $\$ 3.50$. ROEZLII.-Golden yellow: very dwarf; charming. $\mathrm{Pkt}$. I5c. TIGRINUS GRANDIFLORUS.-Very large-flowering tigered and spotted varieties; new; splendid. Pkt. IOc., oz. $\$ 4.00$.

\section{$\operatorname{MIMOSA}$}

(SENSITIVE PLANT).

PUDICA.-Pinkish-white. A very iuteresting and curious plant; its leaves closing if touched or shaken. Annual. I ft. Pkt. 5C., Oz. 75C.

\section{MIRABILIS}

(FOUR-O'CLOCKS).

The flowers open in the afternoon and are in consequence called "FourO'clocks." Perennials. $2 \mathrm{ft}$. Pkt. $5 \mathrm{C}, \mathrm{Oz}$

JALAPA MIXED, fol. var.-Varieties with variegated foliage. $\mathrm{Pkt}, 5 \mathrm{C}, \mathrm{Oz}, 3 \mathrm{OC}$ JALAPA TOM THUMB WHITE.New, excellent for edgings. 9 in. Pkt. 5c., Oz. 50c.

\section{OXALIS.}

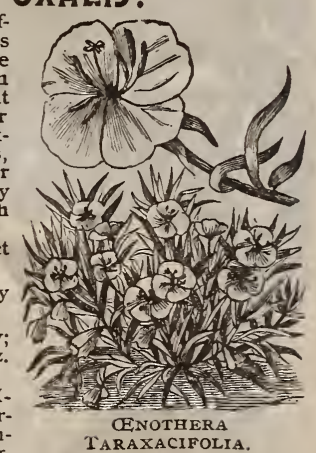
DES.-Yellow, purple foliage a splendid plant for edg-

TARAXACIFOLIA

\section{OENOTHERA}

(EVENING PRIMROSE.)

Charming hardy plants, with large, showy flowers; old favorites in the flower garden, but lately somewhat neglected. They deserve to be more widely grown. The flowers open in the evening, in that sudden and curious manner so well described by Keats as " the leap of buds into de " ACAULIS.-White, shaded, large; flowers all summer. 6 in. Pkt, 5c., oz. \$I.50.

BISTORTA VEITCHIANA.-Yellow, spotted with blood-red; low spreading habit. Annual. Pkt. 5C., oz. 5oc.

MACRANTHA.-Large golden-yellow; fine. Annual. Pkt. 5c., oz. 5oc. 


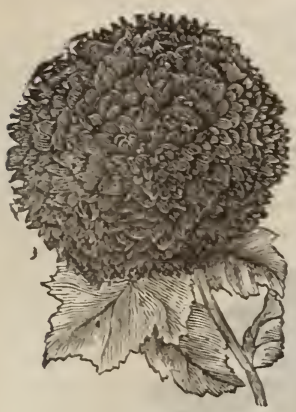

DOCBLE POPPY

\section{POPPIES (PATAVER).}

Brilliant showy plants of the easiest culture ANNUAL VARIETIES.

DOUBLE MIXED. -A choice mixture of the Carnation, Ranunculus and Prony flowered forms; many colors Pl.t $5 \mathrm{C}, 0 \mathrm{z}, 30 \mathrm{c}$

SINGLE MIXED.-Single forms in great variety: many colors. Pkt. 5c., oz, 3oc. proved race of single Poppies, comprising many charming colors and possessing a graceful habit; free blooming and easily grown. PKt. IOC.

PEACOCK POPPY (P. pavoninum). - single Ift. Plet. IOC.

VICTORIA CROSS POPPY - Single rich vermilion with a white spot at base of petals. $1 \frac{1}{2} \mathrm{ft}$. Pkt. Ioc.

UMBROSUM.-Single vermilion and black shaded with ash gray. Pkt. IOc. MEPHISTO.-Single scarlet with large black spots. Pkt. 5c., oz. 75c.

DANISH FLAG POPPY.-Scarlet with white wedge on petals. Pkt. 5c., oz. $50 \mathrm{C}$

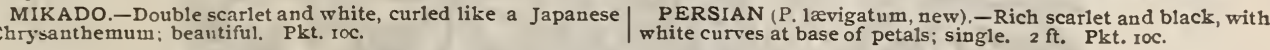

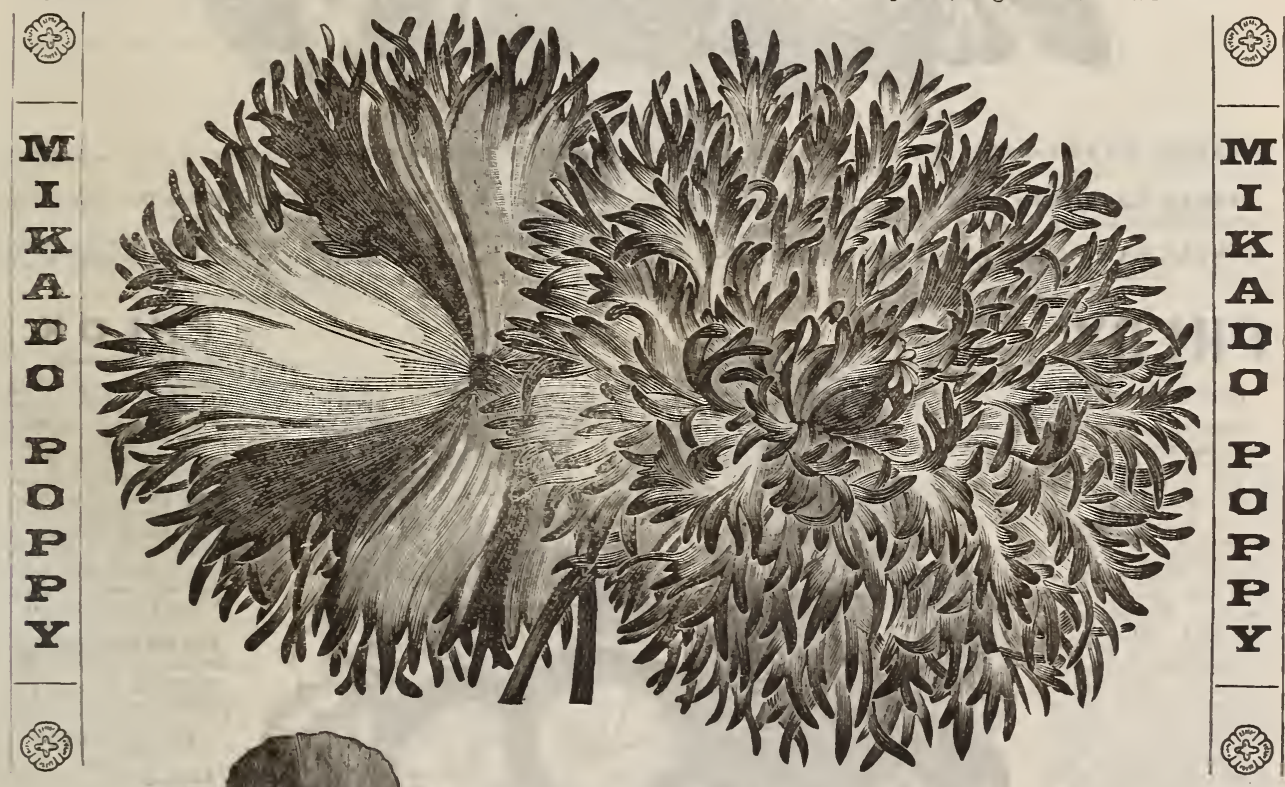

PERENNIAL VARIETIES.

ORIENTAL POPPY.-Dark scarlet with purple spot at base of each petal. teatum; grows about i foot taller, has more frows about I foot taller, has more finely divided foliage

ICELAND POPPIES (P. Nudicaule). This free-flowering, fragrant and beautiful class of Poppies ought to be nore largely grown. Although hardy peren-

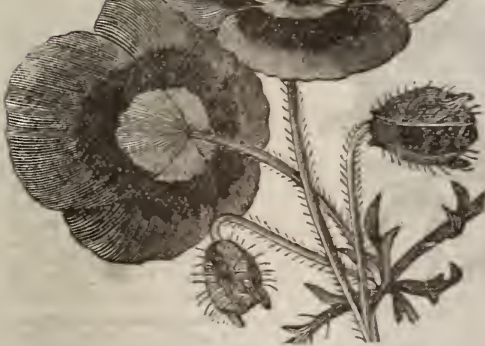

PAPAVER UMBROSUN.

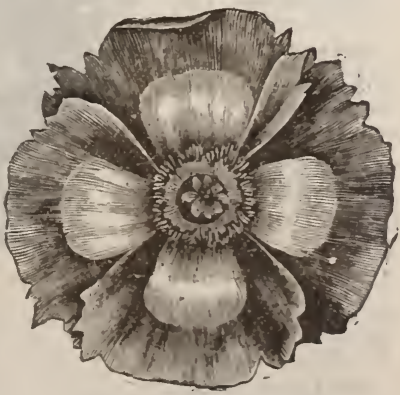

Papaver DaNish Filag. 


\section{me PETUNIAS. som}

Showy and popular plants for the summer garden and growing in pots. They are easily raised from seeds, and continue a mass of bloom the whole season. The seeds are very delicate, and should be sown in March in pans of finelysifted soil, and placed in gentle heat. So soon as large enough, carefully prick out into other pans or puts. Afterwards, when a little larger, pot off singly. Pinch back the shoots to induce shrubby growth. Those intended for the summer rarden made up of two parts loam and one part well-rotted manure. Waterfreels during thesummer. Annuals.
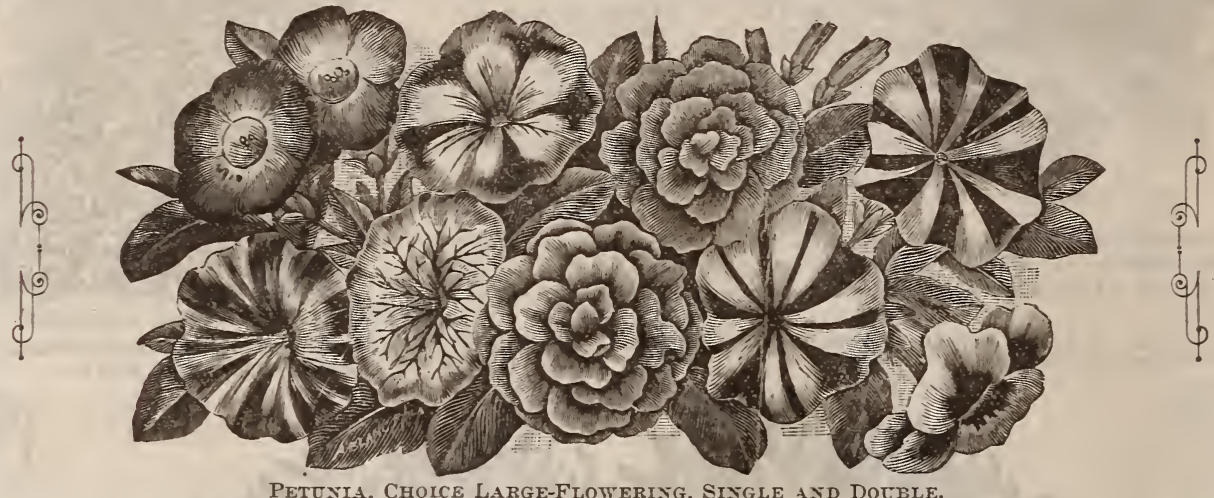

SINGLE, EXTRA-FINE MIXED.-Beautiful striped DOCBLE EXTRA CHOICE.-Large, double-rariegated and blotched rarieties. Packet 5 cents, ounce $\$ 1.50$.

SINGLE LARGE-FLOWERED, EXTRA MIXED.flowers. Packet 50 cents.

Very superior strain. Packet 25 cents.

DOCBLE EXTRA CHOICE, FRINGED.-Charming fringed flowers: beautiful. Packet 50 cents.

COLLECTIONS.-Collection twelve choice single varieSINGLE LARGE-FLOTwERED, FRINGED.-Superb ties, \$1.00. Collection twelre choice double rarieties, s1.25. mixed. Packet 25 cents. Collection six choice double rarieties, 75 cents.

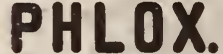

DRUMITNDI.

These flowers are of extreme beautr, and are greatly admired by all; their long duration in bloom, com bined with their almost un equaled richness of color, renders them of invaluable serrice in the general flower den, and a finer sight than a bed of Phlox Drummondi is rarely to be seen. For early to be seen. For early flowering sow in a hot-bed and transplant when the weather is warm; for later flowering sow in the open ground. Set the plants a foot apart. Annuals.

EXTRA MIXED. Choice colors. Pkt. o cts., ounce 75 cts.

GRA TDIFLORA, MI X E D.-Extra large-flowered varie-

NATA SNOWBATI Dwarf; pure white large-flowering. Pkt. 10 cents, ounce $\$ 4.00$.

NANA FIREBALL. Dwarf; brilliant scarlet; large-flowering. Packet 10 cts., oz. \&4. NANA, EXTRA $\mathbf{M I X E D . - C h o i c e ~}$ colors ; dwarf varieties. Pkt.10c., oz. $\$ 3.50$. COLKECTIONS. Twelve large-flowering varieties, 75 cents; collection six largeflowering varieties, 40 cents.

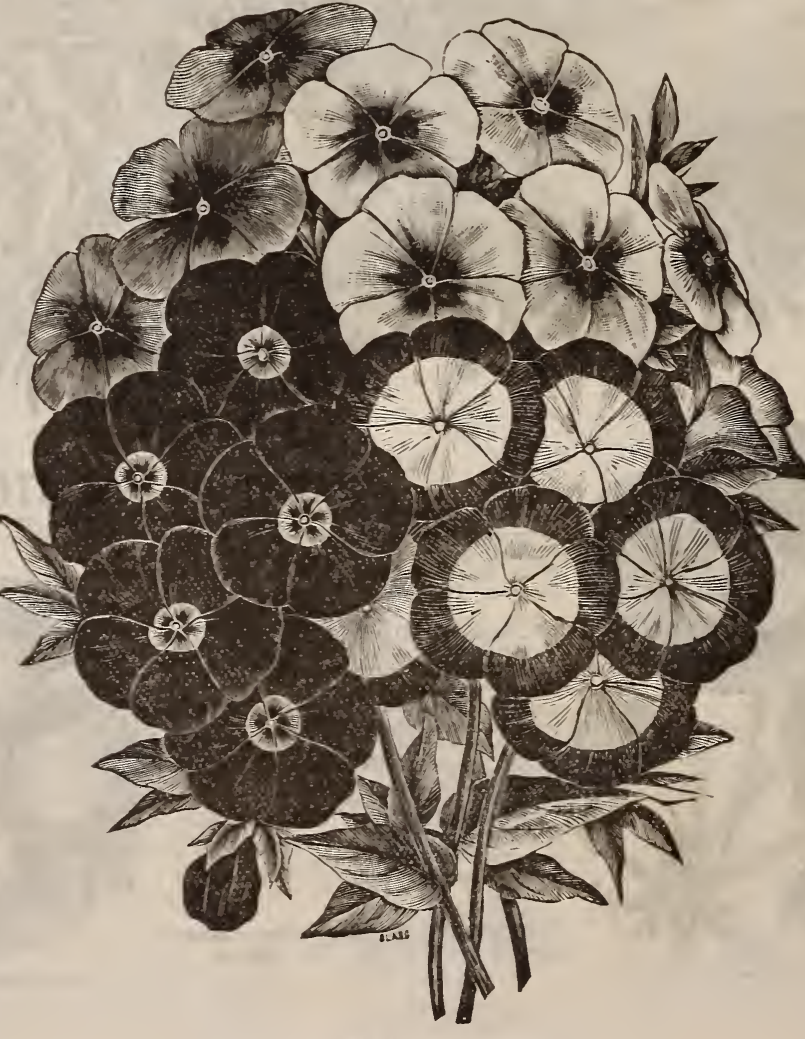

PHLOX DRUMMONDI GRATDIFLORA.
PHLOX.

\author{
(Herbaceous).
}

Decussata.-The perennial phloxes are popular, hardyborder plants with large heads of showy flowers of various colors. They succeed well in ordinary garden soil. Our strain of seed is sared from a collec tion of the newest and choicest sorts. Pkt. 10 cents, ounce $\$ 2.50$.

PICOTEE.-See Dianthus caryophyllus.

PI $\mathbf{X}$ KS.-See Dianthus plumarius.

PHASEOLES (Bean).

Caracalla (Climb ing Snail Flowier). -A beautiful climber ralued for its delicious fragrance and showy orchid-like flowers. Excellent for the grer garden. The flowers are purple: very large; the vexilium and carina spirally twisted. Suc ceed̆s in light, rich loam. Packet 10 cents, ounce $\$ 2.00$.

Yultiflorus (Scarlet Punner)-Verr ornamental on account of its bright scarlet flowers; aiso a good string bean (for culture see PoLE BEaxs) Packet 10 cts., pint 25 cents, quart 45 cents.

Indtiflorus alba. A white variety of the preceding; planted together the effect is excellent. Packet 10 cents, pint 25 cents, quart 45 cents. 
PORTURACA.

For brillant, beautiful, and delicate colors, this charming

Primula Japonica genusstands unrivalled, and whether splendid flowers, produced in the greatest profusion, are extremely effective: succeeds best in light, gravelly soils, or mixed witl lime rubbish. It will stand almost any amount of heat, and revels in our hot, dry climate. Annual.

Double extra mixed.-Choicest colors. Packet 10 cents, ounce $\$ 6.00$. Collection.-Six double varieties, 50 cents.

Single extra mixed.-Choicest colors. Packet 5 cts., ounce 75 cts.

Collection.-Eight single varieties, 40 cents.

\section{POTEXTILLA.}

Handsome herbaceous plants, ex ceedingly ornamental in mixed flower borders, lasting a long time

Double.-Choicevarieties, mixed. One foot. Packet 15 cents.

Single.-Finest mixed. 11/2 feet. Packet 5 cents, ounce 50 cents.

\section{PRIMULA SINENSIS.}

\section{(Chinese Primula).}

Gardiner's Superb Strains.

The following are saved for us by the most celebrated growers in Europe, and are the finest the world affords in their respective classes. They are of large size, rich in color, and of great substance. The Chinese Primula has long been a favorite florist's flower, and it was never seen in greater perfection than now; the specialists in this plant having produced some very rare and remark able varieties within the past few years. They are as indispensable oration as the Cyclamens and cinerarias, and are also excellent for early summer flowering in the garden if placed in some shady corner. Sow either in February or August, in boxes of light rich soil, covering the seeds lightly with a little damp moss. et them stand in a cool moist place for four or five weeks, then lace in frame with bot tom heat. Trhen the plants put on two leaves, transplant into pots, and repeat this operation as the plants grow larger. Tender Perennials.

Sinensis, choice mixed.Extra choice. Packet 50 cents. Sinems

25 cents.

Sinensis Fimbrtata, choicest mixed.-Beautifully fringed. Packet 50 cents.

Simensts Fimbriata, rermleaved, choicest mixed.-Varie ties with finely cut foliage and fringed flowers, extra. Packet $50 \mathrm{cts}$. Sinensis Fimbriata, fl. pl.,
choicest mixed.-Finest doublefringed flowers, extra. Pkt. 50 cts.
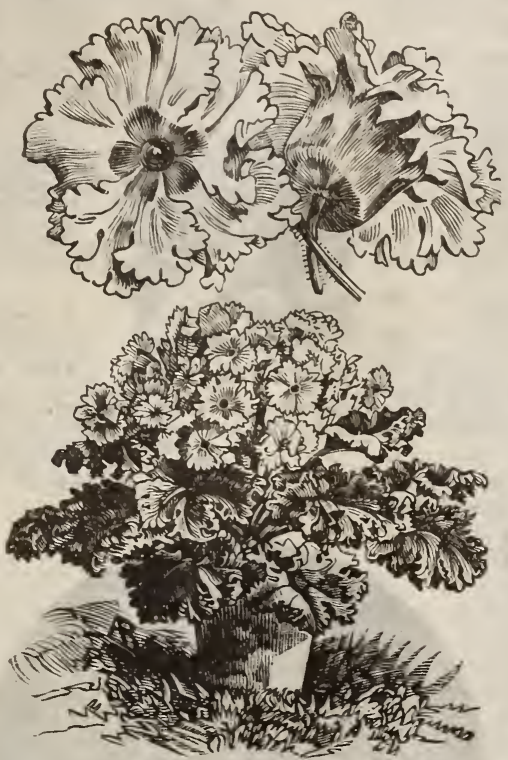

Primula Sinensis. (Chinese Primula).

Japan Primrose). - Most beatutifit crimson, mower colors, white; all witl white eye. Choicest Pactet 25 cents.

Primula Luteola.-Sulphur-yelow, deeper at the throat; in compact heads: handsome spccies. Primula Obconica.-See NovelPrimula Farimosa.-Light nurple, yellow eye, borne in con i)act Prinula Floribunda-Pretty Himalayan Primrose, rellow, posed in whorls on erect scapes. Primula Cashmeriana.-Rich violet-purple; borne in globular imbels ; the stems and foliage covered with golden dust. Pkt. $25 \mathrm{cts}$. Primula Cortusoides.-Rose; in umbels ; dwarf; a most charming ariety. Pacliet 25 cents.

Primula Rosea.-Bright rosycarmine with yellow eye; one inch diameter; disposed in heads of six to ten blossoms: very neat, compact Packet 25 cents.

Primula Sikkimensis.-Pale yellow, one inch long and half an inch across. disposed in drooping form in umbels of from forty to sixty blossoms; very handsome ree-flowering species. Pkt. $25 \mathrm{cts}$. Primula Stuarti.-Rich goldenrellow; handsome; vigorous grower. Packet 25 cents.

Primrose, Dean's Hardy HighColored Horids--Very beautiful strain; awarded first-class certificate R. H. S. Packet 25 cents.

Primrose, English.-Yellow. Packet 15 cent

Polyanthus Gold-Ioaced.-Saved by an amateur, who has one of the finest collections in England. Packet 25 cents.

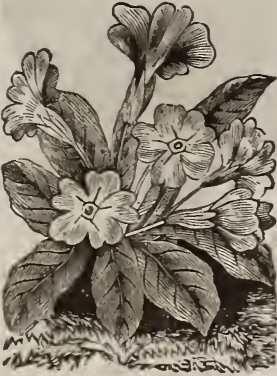

PRIMULA

(English Primrose).

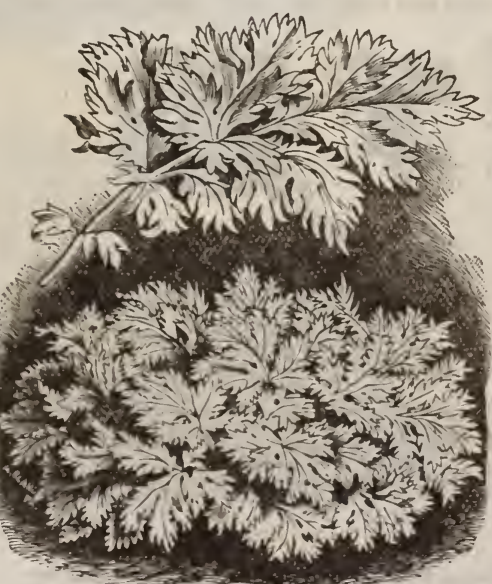

PYRETHRUM AUREUM “GOLDEN FEATHER,"

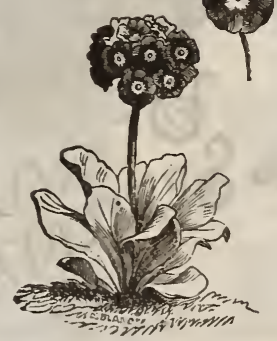

Primula Auricula.

\section{PRIMULA.}

The following varieties are hardier than the Chinese Primula, some of them being able to stand our winters with very little protection. This is notably the case with the Polyanthus and English primroses, and Auriculas. An inverted sod, or a flower-pot inverted and flled with hay or leaves, makes an excellent during winter. As pot-plants they are admirable, and we strongly re commend them for parlor or conservatory decoration during winter and spring. The Primula Obconica, dhesced at another page, is one years for this purpose. We know of nothing that has taken its place so quickly in popular estimation as this, unless it be the Freezia. And it is a peculiar coincidence that the widely different in all other re spects, is almost identical.

Primula Anricula Alpine.Various colors. Six inches. Packet 10 cents.

Primula Auricula English Hy brid s.-Green-edged, etc.; saved from prize flowers

\section{PYRETHRUM.}

Aureum (Golden Feather).Golden foliage, unsurpassed for ribboning; "a ray of sunshine" of dark-folinged plants Start the seeds in heat early in spring to have them large enough to set out by the end of May. Pkt. 5 cents, ounce $\$ 1.25$.

Anreum Golden Gem,-A variety of preceding, very fine. Packet 5 cents, ounce $\$ 1.25$.

Aureum Selaginoides.A nother variety of Golden Feather, with beautifully cut foliage: vers fine. Pkt. 10c., oz, \$3.00.

Hybridum, fl. pl., mixed.-Handsome hardy perennial plants. with a Chrrsanthenum. Two feet. Pkt. 25 cents.

PoLyanthus.-See Primula.

POLEMIONIC'M (Jacob's Ladder).

Coeruleum.-Fine hardy herbaceous perennial, with large licads of blue flowers. Excellent for mixed flower borders. Succeeds best in rather rich, molst soil. One foot. Packet 5 cents, ounce 30 cents.

\section{POPPY.-See Papaver.}

RHODANTHE (Everlasting).

A well-known Everlasting; valuable for the decoration of the conservatory and flower-garden: fine for hedding or ribboning. Halfhardy annual. One foot.

Maculata.-Rosy-purple; crimson centre. Packet 5 cents, ounce $\$ 1.50$. Maculata Alba.-White. Packet 5 cents, nunce $\$ 1.50$.

Manglesi.-Pink; beautiful. Pkt 5 cents, ounce $\$ 1.00$ 
RESEDA (Mignonette).

SALPIGLOSSIS.

A well-known fragrant favorite, which produces a pleas- Ornamental and useful plants for autumn decoration; ing contrast to the more showy occupants of the parterre. their curiously penciled and marbled funnel-shaped flowers If well thinned out immediately the plants are large enough, they will grow stronger, and produce larger spikes of bloom. Excellent for pot duce larger spikes of bloom. Excell

Grandifiora.-Sweet, large flowered. Packet

5 cents, ounce 15 cents.
Golden Queen.-Golden; fragrant; new and fine. Packet 10 cents, ounce 75 cents.

Gabriele.-Red, large spikes, fragrant; a fine new variety. Packet $10 \mathrm{cts}$., ounce $60 \mathrm{cts}$.

Giant White Spiral.-A fine new variety, entirely distinct from other sorts; flowers pure white, in spikes ten inches long; foliage beautifully cut. Packet 10 cents, ounce $\$ 1.00$.

Birds Mammoth.-Very robust habit and long flower spikes; new and distinct. Packet 10 cents, ounce $\$ 1.00$

Giant Pyramidal.-Large, bright red, fragrant. Packet 5 cents, ounce 40 cents.

Machet.-New, the best for pot culture; long spikes; very sweet. Packet 10 cents, ounce $\$ 1$. Miles' Spiral.-Free-flowering, splendid long spikes; fragrant. Packet 5 cts., ounce 60 cts.

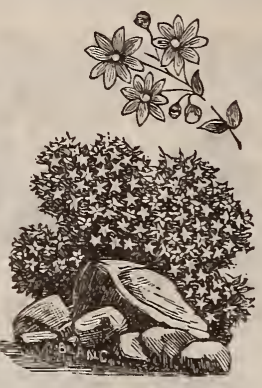

SEDUM CoERULEUM. produce a fine effect in beds, borders, edgings, and ribbons. Sow under glass, and transplant into the open ground as early as weather wil permit. May also be sown about the end of Variabilis finest mixed colors. Packet 10 cts., ounce $\$ 2.00$; SEDUM (Stonecrop).

Neat, attractive little plants, growing freely in baskets, vases, or rock-work; free-flowering and easily grown.

Coeruleum.-Blue; very pretty. Annual. Three inches. Packet 10 cents, ounce $\$ 3.00$.

Mixed.-Aunual and perennial varieties. Packet 5 cents, ounce $\$ 1.00$.

\section{SENECIO (Jacobea).}

A useful and exceedingly showy class of gay-colored, profuse-blooming plants of easy culture; splendid for rock-work or beds.

Fine mixed. - Double varieties. Annual, Two feet. Packet 5 cents, ounce $\$ 1.00$.

Victoria.-Dark red : fragrant. Packet 5 cts, ounce 60 cts. $\quad$ Dwarr mixed.-A beautiful dwarf race, with great variety Parson's White.-

RICINUS (Castor Oil Bean).

of colors. Annual. One foot. Packet 5 cents, ounce $\$ 1.00$. Speciosa.-Purple; a handsome perennial species, blooming the first season from seed; splendid. Two feet. Packet 25 cents, ounce $\$ 5.00$

A magnificent and highly ornamental genus; the picturesque foliage and stately growth, combined with brilliant-colored fruit of the giant varieties, impart to select plantations, shrubberies, and mixed flower borders quite an oriental aspect. Grown as single

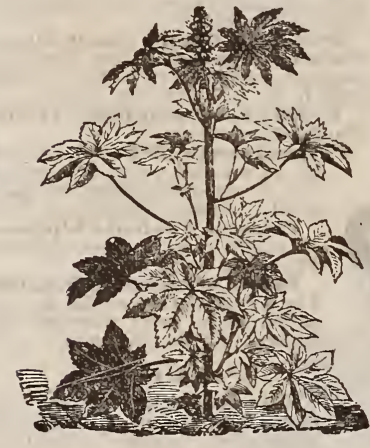

Ricisus.

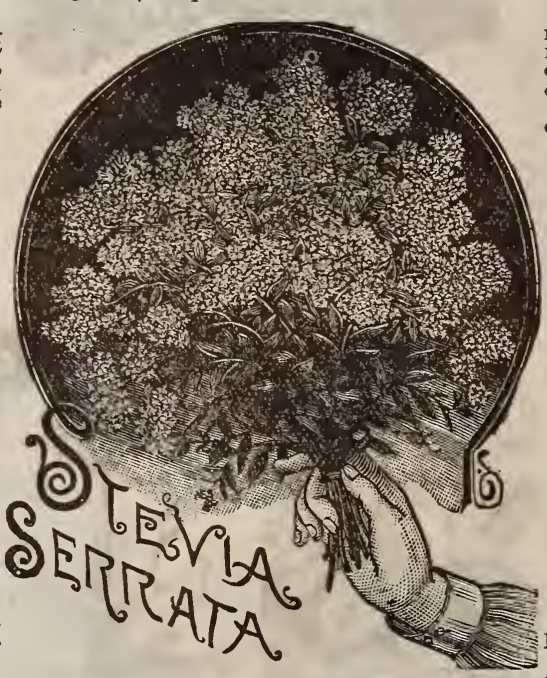

STEVIA.

Splendid free-blooming perennials, extensively used by forists for cut flowers. Splendid for pot or border culture. Tender perennials.

Eupatoria.-White. Packet 5 cents, ounce $\$ 1.50$.

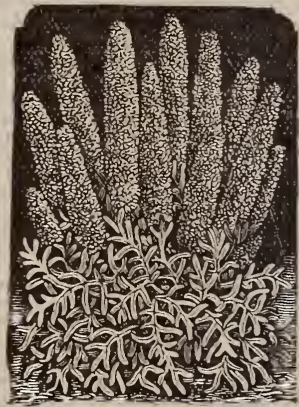

RESEDA (Mignoneite).

NEW WHITE SPIRAL.

Lindl e ya na.-Reddish-white. Packet 5 cents, ounce $\$ 1.50$. Purpurea. - Purple. Packet 5 cents, ounce $\$ 1.50$

specimens on lawns and pleasuregrounds, they form a striking featground is warm in spring. Annual. Borboniensis Aboreis.-Large; dark green foliage. Packet 5 cents, ounce 30 cents.

Cambodgensis. See novelties.

Coerulescens.-Bluish-green foliage and fruit. Ten feet.

Packet 5 cents, ounce 30 cents.

Guyanensis N a n u s.-Dwarf, with rose-colored fruits. Four feet. Packet 5 cents, ounce 30 cents.

Philipinensis.-Large dark foliage. Ten feet. Packet 5 cents, ance 30 cents.

Sangruineus.-Blood-red foliage and fruit. Seven feet. Packet 5 cents, ounce 30 cents.

IIxed.-Many fine varieties.

Packet 5 cents, ounce 30 cents.

\section{ROCIRET, SWEET.}

See Hesperis.

RIVINA (Rouge Plant).

Humilis.-Ornamental evergreen greell-house shrub, with racemes of small, bright scarlet berries; very beautiful and excellent for pot culture; succeeds best in a mixture of leaf-mould and sand. Tender annual. Packet 10 cents.

SABBATIA.

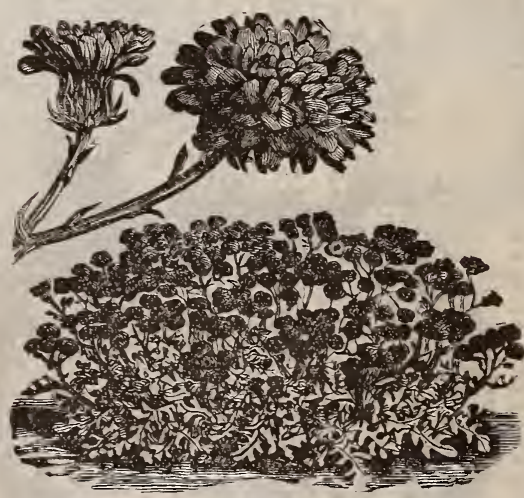

SAIVIA.

Magnificent bedding-plants, loaded with spikes of brilliant flowers, from July till October. Start in a hot-bed and transplant. Succeed best in light, rich soil. Half-hardy annual.

Argentea.-Silvery foliage aud white flowers. Three feet. Packet 5 cents, ounce 75 cents.

Carduacea. - Wooly thistle-like leaves and light blue flowers; very fine. $2 \frac{1}{2}$ feet. " Packet 5 cents, ounce 75 cents.

Cocinea hybrida.-Intense scarlet. Two feet. Packet 5 cents, ounce $\$ 1.00$.

Farinacea.-Bright, light blue flowers, from July to October. Three feet. Packet 5 cents, ounce 125.

Patens.-Beautiful deep blue; a most charming species. Two feet. Packet 20 cents.

Splendens.-One of the most popular fall-blooming plants in cultivation, producing long spikes of beautifuil scarlet flowers; very ornamental. Three feet. Packet 10 cents, ounce $\$ 3.00$.

Campestris.-Rose; a charming annual: verz Ca m pest ris.-Rose; a charming annual; very orna-
mental and desirable for fiower borders. One foot. Pkt. 10c.
pact than preceding. Packet 15 cents. 


\section{TOCK - GILLIFLOWER. $\triangle \wedge \Delta$}

The "Week stock "Gilliflower" as it is called, is an object of nniversal " Gillifiower, as it is called, improved large-flowering Imiration wherever seen in perfection. irain is remarkable for profusion and duration

TEN-WEEK STOCK.

IMPROVED DOUBLE LARGE-FLOWERING.

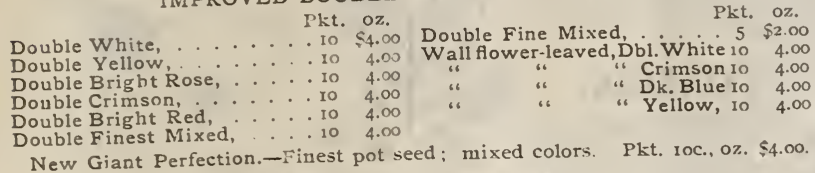

\section{BIENNIAL STOCK.}

Earlest Autumn Flowering.-Finest pot seed ; mixed colors. Pkt. Ioc.

Earhest Autur Perperual - Finest mixed colors. Pkt. Ioc.

Emperor or Perpetual. Finest mixed colors. Pkt. Ioc.

Hardy's all the year Double White.-Finest pot seed. Pkt. Ioc.

\section{SCABIOSA (Mourning Bride).}

A splendid class of annuals for beds or borders; very showy, rich colors; excelA splendid class of annuals for bedsinary garden soil. We cannot recommend lent for cuttiug. Hasily grown

this genus too highly . Exceedingly handsome, Grandiflora fl. pl. Newv: double laries, $30 \mathrm{c}$.

Pktt. 5c., oz. 75c. Collection of flowering varieties; choicest fowering med. I ft." Pkt. 5c. collection of 6 varieoz. $50 \mathrm{c}$.

Candidissima fl. pl.Dom for bouquets. Plt. 5c., oz. 5oc.

\section{SILENE}

\section{(Catchfly).}

ornamental, free-flowering plants, with bright and beautifully colored flowers. Will succeed well in

soil. Annuals. Armeria (Catchfly).-Finest mixed. $2 \mathrm{ft}$. Pkt. 5c., Oz. $40 \mathrm{C}$ Pendula pink and white. 6 Dwarfipink and wo

Pendula Compacta, fl. pl. Pendula 6 ins. Pink and white. Pkt. 5c., oz. 50c.

\section{SALPIGLOSSIS}

("Painted Tube Tongue") A beautiful annual with funnel-shaped flowers, curiously marbled and pencilled. The improved large-flowering varieties areverystriking. ing rarieties areverystring. many colors mixed. Pkt. roc.

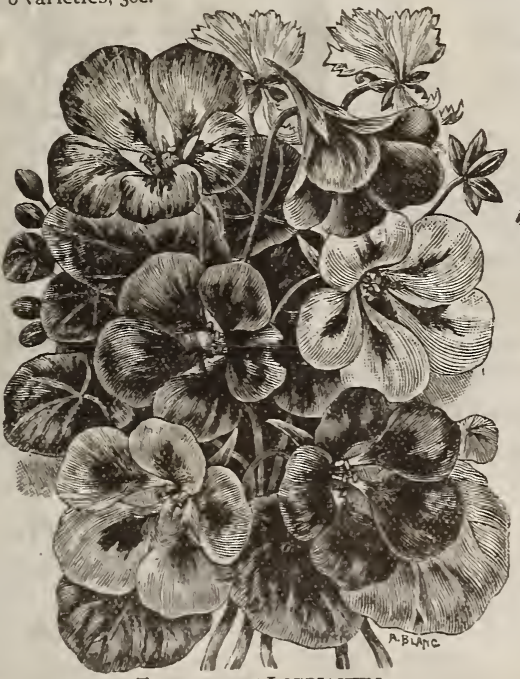

TROP £OLUM LOBBIANUM.

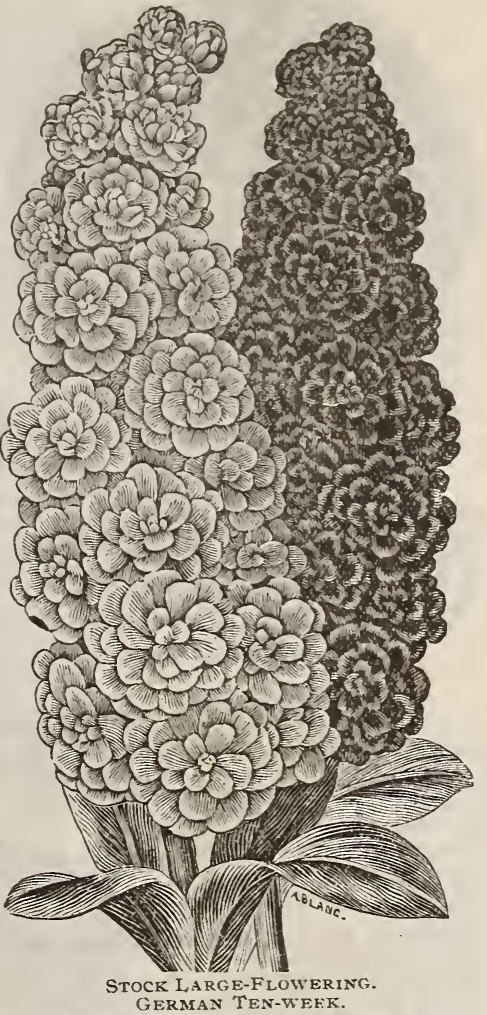

DWARF NASTURTIUM

(Tropæolum nanum). Beauty -Yellow and scarlet.

Scarlet.

Dark Crimson.

Peach.

Empress of India.-Crimson. Oz. $40 \mathrm{c}$

Golden Yellow.

King of Tom Thumbs.-Scarlet.

King Theodore.-Maroon. Oz.

Lady Bird.-Yellow and crimson. Oz. $75 \mathrm{c}$. Yellow.

Pearl.

Rose.

Spotted.

Crystal Palace Gem.-Sulphur, mauve spots.

Ruby King.-Oz. 40c.

FINEST MIXED.

All 5c, pkt., 25c. oz., except where noted.

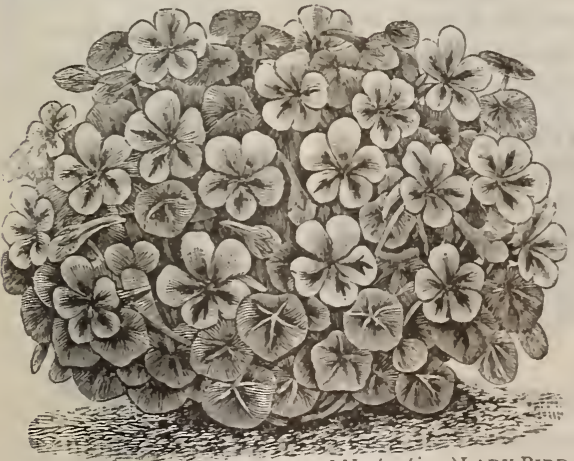

Tropaolum ToM Thumb (Divarf Nasturtium)Lady Bird. All ioc. pkt., 6oc. oz., except where noted.

\section{CLIMBING NASTURTIUM}

(Tropæolum majus).

$\begin{array}{ll}\text { Purple-Violet. } & \text { Orange. } \\ \text { Scarlet Striped. } & \text { Yellow. } \\ \text { Scarlet. } & \text { Straw Color. } \\ \text { Brownish-lilac. } & \text { Finest Mixed. }\end{array}$

All 5c. pkt., 15c. oz.

\section{LOBB'S CLIMBING NASTURTIUM}

\section{(Tropæolum Lobbianum).}

Although smaller in flower and foliage than the tall nasturtium, this race is much superior both in brilliancy of color and profusion of bloom. Blood Red.

Carmine $-\mathrm{Oz}, 50 \mathrm{C}$ Dark Scarlet. Oz. \$1.00.

Golden Yellow,-Striped carmine. Brilliant Scarlet.-Oz. 50c Black. 


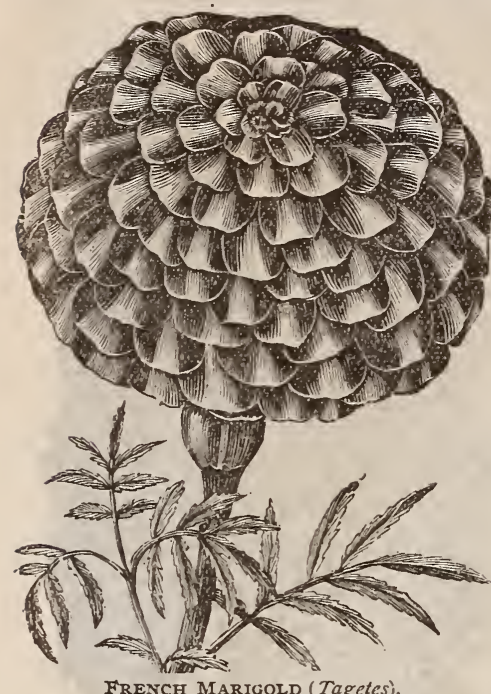

French Marigold (Tagetes).

\section{THUNBERGIA}

(BLACK-EYEd SUSAN).

A genus of slender and rapid growing climbers, with exmired flowers, which are freely produced. Succeed best in light, rich soil in warm situations.

Half-hardy annuals. $5 \mathrm{ft}$. A LA T A A L B A. - White, with dark eye. Pkt.5C., oz. \$I.0O. FIN

\section{TORENIA.}

Beautiful free-blooming trailing plants: excellent subjects for pot culture in the conservatory, and also succeed well in moist, shady spots in the sum. moist, shady spots in the sum-

baskets and vases. Light, rich loam. Tender perennials.
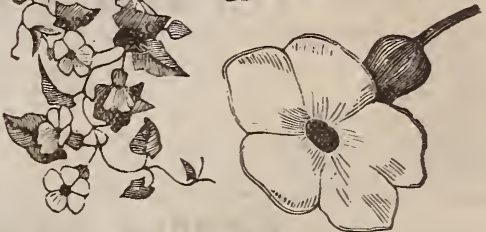

BLACK-EYED SUSAN (Thunbergia).

BAILLONI.--Yellow, with brownish-red throat, Pkt. IOC.

FOURNIERI GRANDIFLORA.-New large-flowered variety. Pkt. I5C.

WHITE WINGS. A pure white vaceding. Very fine. Pkt. 25c.

\section{TAGETES (MARIGOLD).}

Well-known, free-flowering plants, with handsome double flowers, of rich and beautiful colors. The African is the most striking in large beds or mixed borders. The dwarf varieties are also excellent as pot plants for winter blooming. Succeed well in ordinary garden soil. Annuals.

AFRICAN TALL ORANGE.-Large double, orange-colored. Pkt. 5C., oz. 40 c.

AFRICAN TALL LEMON.-Large double, lemon-colored. Pkt. 5C. OZ. $40 \mathrm{OC}$.

AFRICAN TALL QUILLED.-Orange and Lemon; quilled varieties of preceding. Each, pkt. 5c., oz. 5oc.

AFRICAN EL DORADO- - Large flowers, finely imbricated and perfectly double; shading from primrose to deep orange. Pkt. Ioc.

AFRICAN MIXED.-Finest double varieties. Pkt. 5c., oz. $4 c c$.

- FRENCH TALL DOUBLE.-Finest double varieties; mixed. $2 \mathrm{ft}$. Plt, 5C., OZ. $50 \mathrm{C}$.

FRENCH DWARF DOUBLE.-Finest double varieties; mixed. I ft. Plst. 5C., OZ. 50C.

FRENCH DWARF STRIPED.-Orange, with velvet stripes; very fine. Pkt. 5 c., oz. 75 c.

\section{VALERIANA (VALERIAN).}

FINE MIXED.-Showy, easily grown plants, with long, handsome spikes of fragrant, beautiful flowers; excellent for cutting and for borders. Hardy perennials. Pkt. 5c., oz. 5oc.

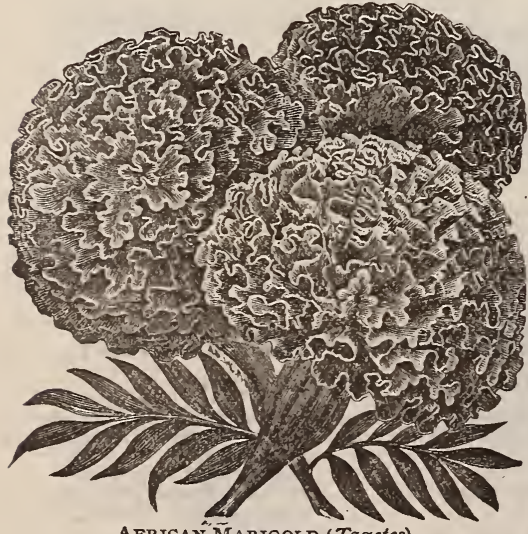

AFRICAN MARIGOLD (Tagetes).

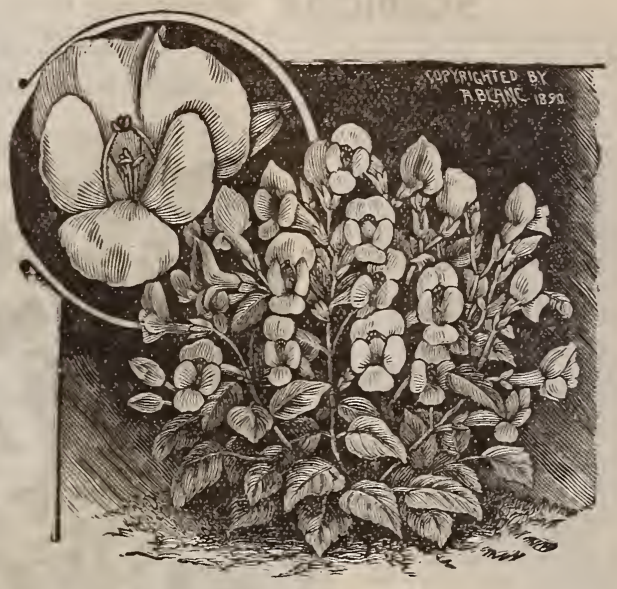

TORENIA WHITE WINGS.

VENEDIUM.

CALENDULACEUM. - Single, golden-yellow, daisy-like flowers. A handsome, low-growing annual, blooming freely until frost. 6 ins. Pkt. 5 c., oz. $75 \mathrm{c}$.

VERONICA.

Showy plants for pot culture, rock-work or the open border; they require but little attention, as they grow with the greatest facility, and are readily increased by partition of the roots.

ANNUAL VARIETIES, FINEST MIXED. -6 in. Pkt. 5 c., oz. \$1.00.

PERENNIAL VARIETIES, FINEST MIXED. $-2 \mathrm{ft}$. Pkt. $5 \mathrm{c} ., 0 z, \$ 1.00$. REPENS.-White, fine dwarf variety; perfectly hardy. Pkt. Ioc.

\section{VINCA}

\section{(PERIWINKLE).}

A class of very pretty, free-flowering perenflowers, May be set out in the garden in a warm situation during the summer and autumn months. Pot and take in-doors before frost. Tender perennials. $2 \mathrm{ft}$.

ROSEA.-Fine rose. Pkt. Ioc., oz. $\$ 1.50$.

ROSEA ALBA. - White, with rosy eye. Pkt. IOC., Oz. \$I.5O.

ROSEA ALBA PURA.-Pure white. PEt. IOC., Oz. \$r.5O.

MIXED.-The above sorts. Pkt. IOc, oz. \$I 50 .

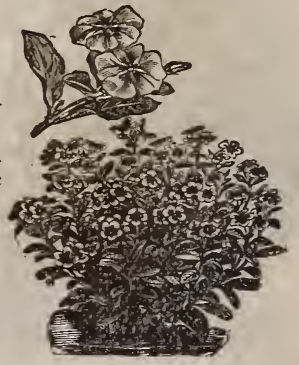

VINCA ROSEA. nials, with shining green foliage and beautiful 


\section{VIOLA TRI-COLOR \\ ("Pansy" "Heartsease").}

\section{NEW L.ARGE FLOWERING SORTS.}

CASSIER'S SUPERB GIANT. - A splendid strain rivalling the IBugnot in size and brilliancy, blotched both on the upper aud lower petals; wonderfully marked and shaded after
style of the finest types of Fancy Pelargoniums. Pkt. $25 \mathrm{c}$. ROEMER'S GIANT.-Attractive strain of very robust and freeflowering habit; blooms large and richly colored. PLt. 25C.

NEW ODIER OR PRIZE BLOTCHED.-A magnificent strain of fine varieties, producing large, liandsome fluwers of great substance and variety of
beautifully blotched. Pkt. $25 \mathrm{C}$.

TRIMARDEAU GIANT. - An entirely distinct and beautiful race, producing flowers of very large size. The blooms, which are of the richest aud most varied shades of color, are thrown well above the fuliage. Each one is inarked with three large blotches. SUPERB ENGLISH FANCY.-This we believe to be the finest strain of English Fancy in cultivation, saved from the finest named and seedling sorts. Pkt. 25c.

SUPERB ENGLISH SHOW.-A very pure strain, which has been saved by the same grower from the niost choice varieties, witl equally as much care as the Fancy, and mavbe re"i d upon to produce quite as satisfactory results, and in a great variety in character and color of flowers. Pkt. 2.5. specially for our trade by one of the most successful growers in

BELGIAN BLOTCHED - Very choice. Pkt. $25 \mathrm{c}$.

GNOT'S FRENCH.--New French strain, of fine, robust growth: great variety of colors the flowers are of great subthe foliage. Pkt. 25c. FRENCH STAINED.Superb strain: very large, finely-formed flowe

GARDINER'S "INTERNATIONAL PRIZE,", MIXED.-special mixture prepared by ourselves from above sorts. We think this well deserves the title '. International," representing, as it does, the highest perfection does, the highest perfection this favorite flower. Pkt. $25 \mathrm{c}$.
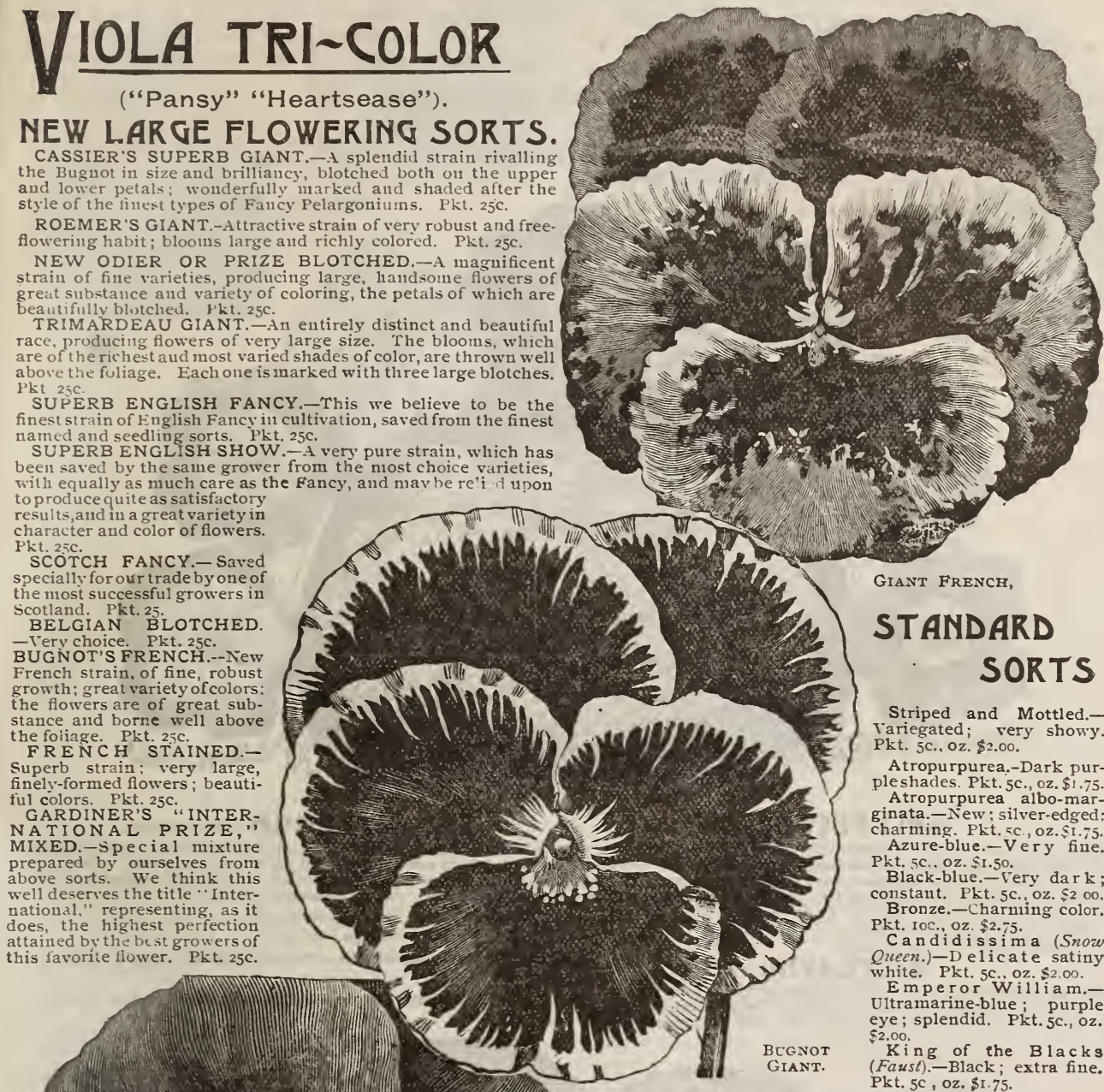

Giant French,

\section{ST ANDARD} SORTS

Striped and Mottled.ariegated; very showy. Atropurpurea.-Dark purpleshades. Pkt. 5c., oz. $\$ 1.75$. Atropurpurea albo-marginata.-New; silver-edged charming. Pkt. 5C, oz, \$I .75. Azure-blue.-Very fine. Pkt. 5c., oz. \$r.5o

Black-blue.-Very dark; constant. Pkt. 5C., oz. $\$ 200$. Bronze.-Charming color. Pkt. Ioc., oz. \$2.75.

Candidissima (Snoze Queen.)-D elicate satiny hite. Pkt. 5c.. oz. \$2.00. Emperor William.Uitramarine-blue; purple eye ; splendid. Pkt. 5c., oz. King of the Blacks (Faust).-Black; extra fine. Pkt. 5C, oz. \$1.75.

Fawn.-Beautiful fawn color. Pkt. 5c, oz. \$2.00. Gold-margined.-Splendid; very showy. Pkt. 5c., oz. \$r.75. Havanna-brown.-New shades; charming. Pkt. 5c., oz. \$r.75.

Light-blue.-Sky-blue; a lovely shade. Pkt. 5c., oz. \$1.75. Mahogany.-Peculiar shade; extra. Pkt. 10c., oz. $\$ 2.50$. White-margined.-Violet, margined with white; extra. Pkt. 5c., oz. \$1.75.

White,-Pure white, with biack centre; very striking. kt. 5c., oz. $\$$ I. 75 .

Yellow.-Pure yellow, with black centre; very showy. Pkt. 5c., oz. \$1.75.

Yellow Gem.-Pure yellow; beautiful. Pkt. 5c., oz. $\$$ I.75. Extrs choice mixed.-Very handsome, large flowering sorts. Pkt. roc., oz, $\$ 3.00$.

Fine mixed.-Tery good quality. Pkt. 5c., oz. \$1.50.

\section{SOWING THE SEED.}

Pansy seeds may be started in heat about February or March If no greeu-house is convenient a sunny window will answer. Sow lightly in fine loam, in a box or flowerpot, and transplaut when well up. Transplant several times pot, and transplaut when well up. Transplant several times buds as soon as they appear, and from early fall until the guds as soon as they appear, and frome early fall until the grow. Seeds sown in a cool place in June, or later, and kept well watered, will produce fall flowering plants. Sow also in September for winter flowering. 


\section{$\cdots$ 活VERBENA $\ldots \ldots$}

WHITE HYBRIDS,

BLUE HYBRIDS,

AURICULA-FLOWERED HYYBIDS, ....... " IO GOLDEN-LEAVED SCARLET, “. I0

HYBRIDS, FINE MIXED,. . “ IO HYBRIDS, EXTRA FINE MIXED,. . . . . : “ NEW $\dot{M} \dot{A}$ M

VERBENA MONTANA.-A perfect gem. The plant literally covers

itself, during summer, with its bright, rose-colored flowers. Hardy Annual. Pkt. 5c., oz. 75 c.

(6)
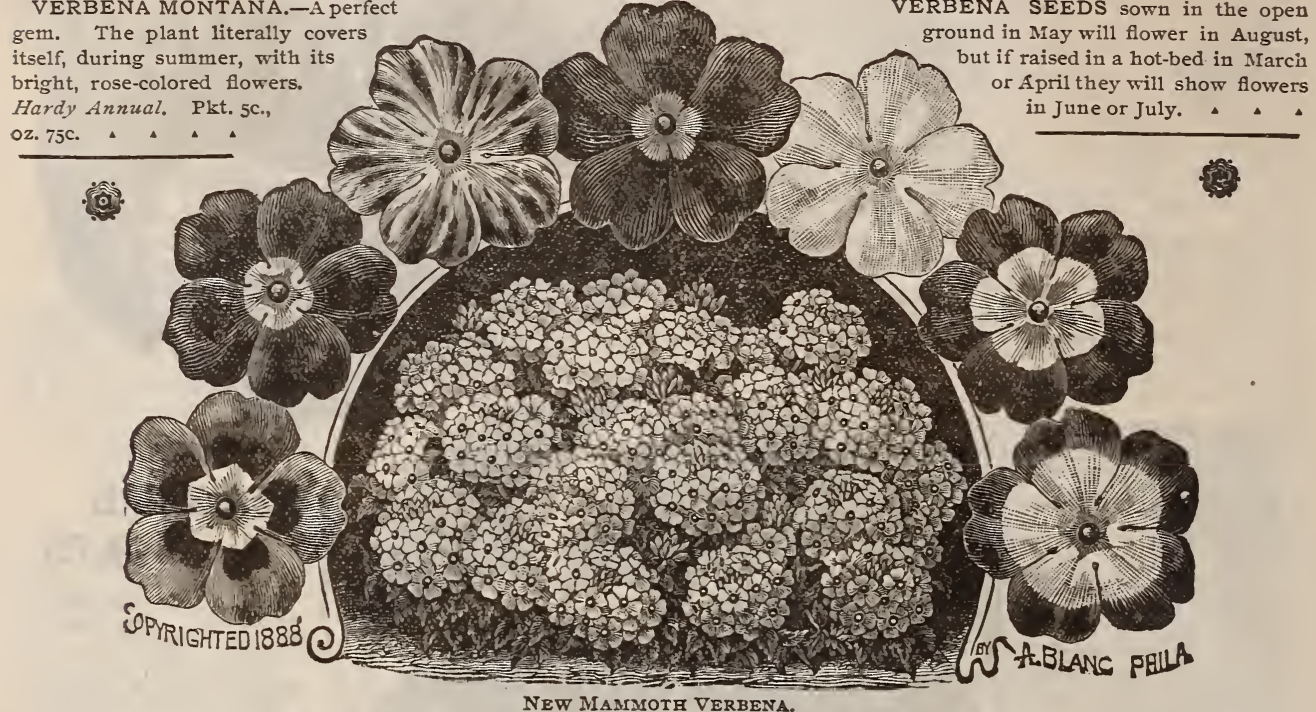

VERBENA SEEDS sown in the open ground in May will flower in August, plendor of its dazzling brilliancy of flower. Plants grown seeds are fragrant, and also thrifty growers and free bloomers.

W ALLFLOWER.

This deliciously fragrant flower is invaluable for beds, bcrders, and bouquets. The conspicuous spikes of the double German, varieties have a charming effect, while the more bushy, compact growth and profuse blooming of the single ones render them exceedingly attractive. Half-hardy perennials.

Finest Double.-German mixed. 2 ft. Pkt. Ioc., oz. \$4.00.

Single Mixed.-Pkt. 5c., oz. $40 \mathrm{C}$.

\section{WHITLAVIA.}

Mixed.-Tery showy, free-flowering annuals, of dwarf habit and corered all summer with pretty bell-shaped flowers. Com mon garden soil. Hardy annuals. I ft. Pkt. 5c., oz. $40 \mathrm{C}$.
XERANTHEMUM (Everlasting).

A beautiful genus of Everlasting flowers, with bright, showy flowers, which are unsurpassed for winter bouquets. Should be cut before they are fully expanded. Of easy cultivation in ordinary garden loam. Hardy annuals. $1 \frac{1}{2} \mathrm{ft}$.

Double White.-Pkt. 5c., oz. \$I.00.

Double Purple.-Pkt. 5c., oz. \$1.00.

Double Pompon, White.-Pompon-flowered, extra. Pkt. 5c., oz. \$r. $\infty$.

Double Pompon, Purple.-Pompon-flowered, extra. Pkt. 5c., oz. \$1.00.

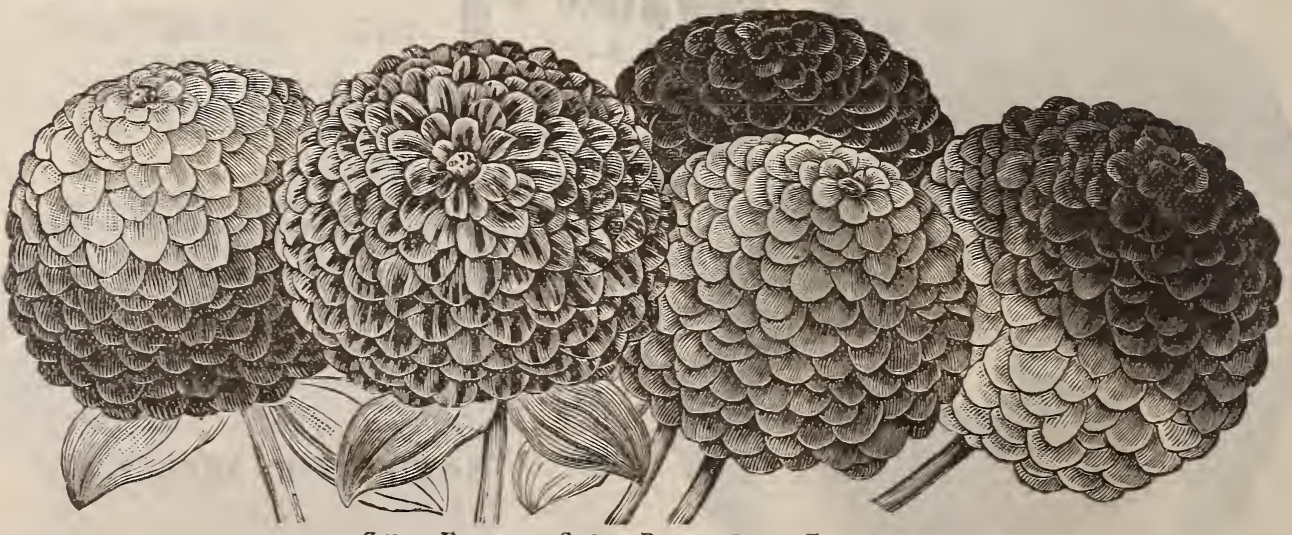

ZiNNIA ELEgaNS. ChOTCE DOUBLE, LARGK-FLOWERED.

7T. The large double-flowering Zinnia ranks high in public estimation as a showy, free-flowering, easily 11.2. $\begin{aligned} & \text { grown plant for the summer garden. The finer strains of the large-flowering sorts are really magnificent, } \\ & \text { the plants being covered from July till frost with a profusion of the handsomest blossoms, in all shades }\end{aligned}$ from pure white to dark crimson. To have them flower early, seed should be started in heat and after wards transplanted to the open ground. Hardy annual.

Elegans Choice Double.-White, scarlet, and mixed. Each, Elegans Choicest Double Dwarf.-White, yellow, scarlet and pkt. 5C., oz. \$1.00. Collection six colors, $30 c$. mixed. Each, pkt. 5c, oz. \$1.50. Collection, six colors, $30 \mathrm{c}$. 


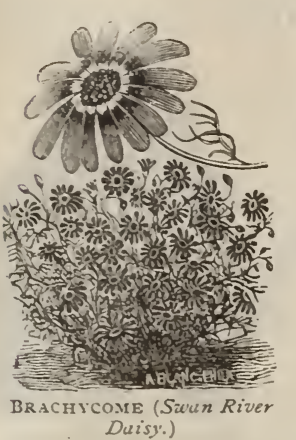
Anemone.-Handsome, herbaceous plants. Hardy perennial.
Chinensis Single Mixed.-1/2ft. Pkt. sc. Fulgens Single Scarlet. $-1 \mathrm{ft}$. Pkt. 2nc. Japonica Roses. $2 \frac{1}{1} / 2 \mathrm{ft}$. Pkt. 1oc. Japonica Alba. - White. Pl. $10 \mathrm{c}$

Angelonia Grandiflora.-Scarlet, with white spots; in spikes; excelleut fur pots. Tender perennials. $1 / 2 \mathrm{ft}$. Pl. $20 \mathrm{C}$.

Argemone Grandiflora (Prickly' Poppy).-White. Hardy annual. $2 \frac{1}{2}$ it. L'k. $5 \mathrm{c}$.

Artemesia Gracilis.-Graceful, decorative plant, with fine foliage. Hardy annual. Pkt. 5c.

Baptisia Australis.-Pea-shaped flowers; bright blue; beautiful. Hardyperennial. $2 \mathrm{ft}$. Pkt. $5 \mathrm{c}$.

Begonia.-Splendid free-flowering genus, with beautiful foliage and large, brilliantly colored blossoms. Seeds very expensive and require handling with exceeding care. Tender perennials. Single and double, choicestmixed. Pkt. 50c. FroeMetallica.-Handsome foliage. Pkt. $50 c$.

Brachycome (Swan River Daisy,) (see cut).-Fine for pots, borders or rockeries. Hardy annual. Blue and white mixed. Pbt. 5c.

Bignonia Radicans (Trumpet Vine).-Climber; beautiful red trumpet flowers. Hardy perennial. Pkt. $25 \mathrm{c}$.

Bocconia Japonica.-Stately and picturesque herbaceous plant, flowers white; in spikes; handsome foliage. Hardy perennial Pkt, 10c.

Bryonopsis Erythrocarpa.-A most beautiful climber with handsome foliage and fruit. Pkt. $5 \mathrm{C}$.

Calampelis Scabra.-Handsome climber; orange flowers and beautiful light-green foliage. Half-hardy perennial. Plt. Ioc.

Calandrinia Umbellata.-Bright crimson; exceedingly beauti ful; profuse bloomer. Hardy annual. $1 / 2 \mathrm{ft}$. Pkt. 5c.

Callirhoe Pedata nana.-Deep rose; profuse bloomer; beautitul. Hardy annual. $1 \mathrm{ft}$. Pkt. 5c.

Castileja indivisa.-One of the most remarkable of recent introducions, produces brilliant scarlet flower-bracts; very rich. Hardy annual. Pkt. $20 \mathrm{c}$.

Campanula (Canterbury Bells). - The following are worthy of a place in every garden: Carpatica,-Hardy perennial. I ft. Blue, white. Pkt. 5c. Leutweini.- White. Hardy Perennia. $2 \mathrm{ft}$. Pkt. 25c. Loreyi.-Hardy annual. $1 \mathrm{ft}$. Blue, white. Pkt. 5c. Macrostyla.-Violet. Hardy annual. $1 \mathrm{ft}$. Pkt. $15 \mathrm{c}$. Media -Single mixed, double mixed. Hardy perennial. $2 \mathrm{ft}$. Pkt. $5 \mathrm{c}$. M. calycanthema, mixed.- Very fine (Cupped). Pkt. 10c. Nobilis.-Drooping flowers. 3 ins. in length. Blue, white. Half hardy perennials. $21 / 2 \mathrm{ft}$. Pkt. $25 \mathrm{c}$. Persicifolia.-Fine for cutting; blue, white. Half-hardy perennial. 21/2 ft. Pkt. Ioc. Speculum ( Venus' looking-glass).-Excellent for bedding. Hardy annual. $1 / 2 \mathrm{ft}$ Mixed. Pkt. 5c. Turbinata.-Flowers 2 ins diameter; very desirable perennial. Blue $5 \mathrm{c}$. pkt., white $25 \mathrm{c}$. pkt. Vidali.-Large racemes of waxy white flowers. Tender perennial. Pkt. $15 \mathrm{c}$.

Clintonia Elegans.-Handsome free-flowering plant; bright blue; file for borders, baskets and rock-work. Hardy annual. $1 / 2 \mathrm{ft}$. Pkt. $5 \mathrm{c}$.

Cosmidium Burridgeanum.-Crimson and yellow. Hardy annual. $2 \mathrm{ft}$. Pkt. $5 \mathrm{c}$.

Cosmanthus Fimbriatus.-Lilac and white; fringed. Hardy annual. I ft. Pkt. 5c.

Crucianella Stylosa.-Dink, showy and free-flowering. Hardy. perennial. I ft. Pkt. $5 \mathrm{C}$.

Cucumber, Ornamental (Cucumis; Cucurbita) - Very curious climbing or trailing annuals, with large foliage and ornaniental fruit. Flexuosus (Snake Cucumber).-Pkt. 5c. Dipsaceus (Teasel cucumber).-Pkt. 5c. Argyrosperma.-I.arge fruit finely striped and mottled. Pkt. 5 c. Leucantha.-Very remarkable: long fruit. Pkt. 5 c.
Commelina Coelestis.-Pretty free-flowering tuberous-rooted erennial, blooming the first season from seed. The roots may ple kept 5 .

Cynoglossum Coclestinum.-Handsome, free-flowering border plant, with blue flowers. Excellent forcutting. Hardy annual. Pkt. 5c.

Datura (Trumpet flower).-Large, fragrant, trumpet-shaped lowers. Excellent plants for massir.g. Double mixed. Pkt. 5c. Echeveria.-Free growing succuients used for beds, rockwork, etc. Half-hardy perennial. Mixed varieties. Pkt. 25 c.

Egg Plant.-Purple and white; very pretty fruit. Pkt. $5 \mathrm{c}$.

Erysimum.-Orange and yellow; showy spikes; fine for beds and borders. Hardy annual. 11/2 ft. Pkt. $5 \mathrm{c}$.

Euphorbia (Snow on the Mountain).-Variegated foliage; a showy border plant. Hardy annual. 1/2 ft. PKt. 5c.

Eutoca.-Showy plant from California, excellent for beds and mixed borders. Hardy annual. $11 / 2 \mathrm{ft}$. Mixed. Pkt. $5 \mathrm{C}$

Exacum Affine.-Elegant compact growing biennial, wit clusters of beautiful violet-purple flowers; very fragrant. sown early will bloom first season. $1 / 2 \mathrm{ft}$. Plet. $15 \mathrm{c}$.

Fenzlia Diant hiflora.-Lovely little plant for window boxes or small beds and,borders; blooms freely all summer. Hardy annual. $1 / 4 \mathrm{ft}$. Pkt. $10 \mathrm{c}$.

Ficus Elastica (India-Rubber Plant), - Valued for its beantifu dark-green leathery foliage and graceful habit, much used for decorating. Half-hardy shrub. Pkt. 25c.

Gaura Lindheimeri.-White flowers with lively red calyx excellent for cutting and fine for mixed baskets and vases, on the lawn or veranda. Hardy annual. $2 \mathrm{ft}$. Pkt. $5 \mathrm{C}$.

Geum Coccineum, fl. pl.-Double bright scarlet, handsome hardy perennial. $2 \mathrm{ft}$ Plt. $5 \mathrm{c}$.

Gilia, finest mixed.-Dwarf; free-flowering; hardy annual; fine for borders, etc. Pkt. $5 c$.

Gladiolus.-Saved from a splendid collection. Half-hardy perennial. $3 \mathrm{ft}$. Pkt. Ioc. Lemoines Hybrids.-Very choice. Pkt. $15 \mathrm{c}$.

Gnaphalium (Edelweiss).-Snow-white Alpine, for the rockery, etc. Hardy perennial. $1 / 4 \mathrm{ft}$. Plt. $25 \mathrm{c}$.

Glaucium Corniculatum (see cut).-Fine silvery foliage ; very graceful. Hardy percnnial. $1 \mathrm{ft}$. Pkt. $5 \mathrm{c}$.

Gomphrena (Globe Amaranth),-Handsome everlastings: white, purple, orange, etc. Hardy annual. $2 \mathrm{ft}$. Mixed colors. Pkt. 5c.

Grammanthes Gentianoides.-Star-shaped, orange-scarlet flowers; dwarf and fine for baskets. Hardy annual. 1/ ft. Pkt. $20 \mathrm{C}$

Grevellia Robusta.-Decoratire greenhouse plant ; esteemed for its beautiful foliage. Half-hardy perennial. $3 \mathrm{ft}$. Pkt. $10 \mathrm{C}$.

Gypsophila (Baby's Breath).-Graceful white panicles of small flowers : excellent for mixing. Hardy perennial. $2 \mathrm{ft}$. Pkt. $5 \mathrm{c}$. Muralis.-Rose. Hardy annual. $3 / 4 \mathrm{ft}$. Pkt. 5c. Elegans.-White. Hardy annual. $1 \frac{1 / 2}{\mathrm{ft}}$. Pkt. $5 \mathrm{c}$.

Hedysarum Coronarium (French Honeysuckle).-Showy plant forborders. Hardy perennial, $2 \mathrm{ft}$. Mixed colors. Pkt. 5C.

Hesperis (Sweet Rocket). - A well-known herbaceous plant; fragrant; early flowering; easily grown. Hardy perennial. 11/4 ft. Pkt. $5 \mathrm{c}$.

Hibiscus Africanus.- Yellow, with dark maroon centre. I.arge and handsume. Hurdy annual. $2 \mathrm{ft}$. Pkt. 5c,

Honesty or Satin Flower (Lunariu biennis). - The silveryseed porls are nuch used for winter decorations. Hardy biennial. 2 it. I'kt, $5 c$. 


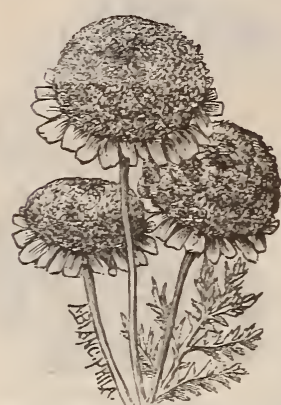

Matricaria (FEverfew).

Humea Elegans.-Rose, swe

hardy biennial. $3 \mathrm{ft}$. Pkt. IOc. Humulus Japonicus (Japanese Hop).-Rapid-growing vine, Hardy annual. Pkt. Icc.

Hyacinthus Candicans (summer Hyacinth).-Long spikes of pure white bell-shaped flowers; splendid herbaceous plant. Hardy perennial. $3 \mathrm{ft}$. Pkt. $5 \mathrm{C}$.

Impatiens Sultani (Sultan's Balsam). - A single-flowering perennial Balsam from Madagascar, with rich carmine-magenta flowers; free bloomer: magnificent. Tender perennial. I I $1 / 2 \mathrm{ft}$. Pkt. I5

Ipomopsis (Standing Cypress).-Brilliant orange and scarlet long spikes; beautiful. Hardy biennial. $4 \mathrm{ft}$. Pkt. $5 \mathrm{C}$

Kaulfussia Ammelloides,-Beautiful dwarf annual; mixed colors. Plrt. $5 \mathrm{C}$.

Lantana $\mathrm{H}$ ybrida.-Elegant half-hardy perennial, with beautiful trusses of flowers; excellent for pots or the summer garden mixed colors. Pkt. IOC.

Lathyrus Latifolius (Perennial Sweet Pea),-Flowers second season from seed; very beautiful scarlet and white flowers. Hardy perennial. Pkt. Ioc.

Layia Elegans.-Golden yellow flowers 2 in. in diameter Hardy annual. $3 / 4 \mathrm{ft}$. Pkt. $5 \mathrm{c}$.

Leptosiphon.-Beautiful flowers and foliage. Hardy annual. $1 / 2 \mathrm{ft}$. Mixed colors. Pkt. $5 \mathrm{c}$.

Limnanthes Douglasi.-Yellow and white; fragrant, magnificent plant for bees. Hardy annual. $1 / 2 \mathrm{ft}$. Pkt. $5 \mathrm{C}$

Lophospermum Scandens.-Purple; handsome climber for the conservatory. Tender annual. Pkt. Ioc. Coccineum.Scarlet Pkt 10c Hendersoni.-Rosy carmine. Pkt. ioc

Lupins.-Very attractive and easily grown plants, producing long spikes of flowers of various colors. Annual varieties mixed. Pkt. 5c. Perennial varieties; mixed. Pkt. 5c.

Lychnis. Showy, free-flowering, herbaceous plants. Hardy perennial. $2 \mathrm{ft}$. Mixed colors. Pkt. $5 \mathrm{C}$

Malva (Curled Mallow).-Beautifully curled foliage. Hardy annual. $5 \mathrm{ft}$. Pkt. 5c. Moschata.-Musk-scented; rosy white. $2 \mathrm{ft}$. Pkt. $5 \mathrm{c}$

Martynia Fragrans.-Very handsome, purple flowers; the fruits make fine pickles. Half-hardy annual. $2 \mathrm{ft} \mathrm{Pkt}$. 5c.

Matricaria (Double White Feverfew). - Dwarf half-hardy perennials, largely grown for cutting; also excellent for borders Plible white Pkt.

Mathiola (Evening Scented Stock). - A very interesting flower opens in the evening; very fragrant pink and lilac flowers. Hardy annual. I ft. Pkt. 5C.

Mina Lobata.-A strikingly beautiful climber, with vivid red flowers changing to white when fully open; very profuse bloomer. Hardy annual. Pkt. Ioc.

Molucella (Shell Flower) - A very curious flower. Hard annual. I ft. Plet. $5 \mathrm{C}$.

Myosotis (Forget-Me-Not).-This pretty little blue perennial shonld he grown in a shady situation. Pkt. IOc.

Myosotis Alpestris.-Blue; valuable for bedding. Pkt. $5 \mathrm{C}$

Myosotis Dissitiflora.-Dark blue: very popular for early spring bedding. Pkt. Ioc.

Myosotis Azorica. - An annual variety; blue and white mixed. Pkt. inc.

Myosotis, Mixed.-Many fine sorts. Pkt. IOC.

Nemesia.-Exceedingly pretty, free-blooming annual. Hardy annual. $3 / 1 \mathrm{ft}$. Mixed colors. Pkt. $5 \mathrm{c}$.

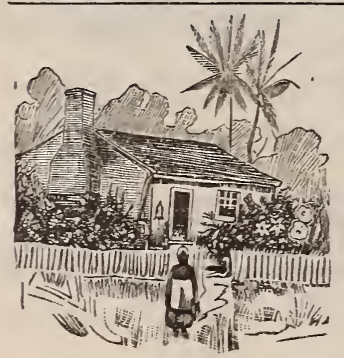

MIXED FLOWER SEEDS.

Many fine varieties mixed, all easily grown kinds; mary of them rare and beautiful. Also a good proportion of standard and favorite varieties. Nothing better for odd spaces. Valuable for cutting. Half-ounce packets, $25 \mathrm{c}$.

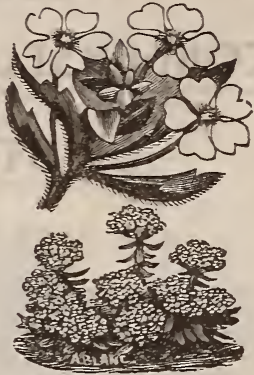

NTCTERINTA CAPENSIS. Nemophila.-Charming dwarr annual, with neat, compact habit and strikingly beautiful flowers. Hardy annual. $1 / 2 \mathrm{ft}$. Mixed colors. Pkt. $5 \mathrm{C}$.

Nierembergia.-Fine for hanging baskets or edgings. Hardy nnual. $1 \mathrm{ft}$. Pkt. Ioc.

Nigella (Love-in-a-Mist). - Showy flowers and finely cut foliage. Hardy annual. I ft. Mixed colors. Pkt. 5c.

Nolana.--Pretty trailer; excellent for hanging baskets. Hardy annual. I ft. Mixed colors. Pkt. 5c.

Nycterinia. - Neat, compact little plants, covered with starNycterinia.- Neat, compact little plants, covered with star-
shaped flowers; sweet scented; very pretty. Hardy annual. $1 / 2 \mathrm{ft}$. Capensis. - White, yellow centre. Pkt. roc. Selaginoides. Lilac. Pkt. Ioc.

Orobus.-Beautiful hardy perennial, with pea-shaped flowers. Pkt. 5c.

Oxyura,-Golden yellow, edged with white; showy and free. flowering. Hardyannual. Pkt. 5c.

Passifiora (Passion Flower).-Splendid climbing vine. Tender perennial. Blue. Pkt. Ioc. Scarlet. Pkt. Ioc.

Pelargonium (Geranium).-Large flowering and ornamental leaved varieties; splendid mixture. Pkt. 50c.

Pentstemon.-Elegant herbaceous plants, with long, handsome spikes of richly colored flowers. Hardy perennial. Many some spikes of richly colored flowers. Hardy perennial. Many fine varieties, mixed. Pkt. 5c.

Perilla.-Dark purple leaves, beautifully crisped at edges. Half-hardy annual. I I $/ 2 \mathrm{ft}$. Pkt. $5 \mathrm{c}$.

Phacelia.-Beautiful annual from California; mixed varieties. Pkt. IOC.

Sanvitalia.-Handsome, free-flowering, hardy annual of trailing habit, with double, light golden-yellow flowers. $1 / 2 \mathrm{ft}$. Pkt. IOC. Saponaria (Bouncing Bet).-Charming annual of neat, dwarf habit: mixed colors. Pkt. 5c.

Schizopetalon.-White, curiously-cut, star-shaped petals ; fragrant and charming annual. $1 / 2 \mathrm{ft}$. Pkt. $5 \mathrm{c}$.

Schypanthus. - Beautiful climber for the conservatory or summer garden; yellow. Pkt. IOc.

Solanum.-Highly decorative green-house plants, with fine Solanum.-Highly decorative green-house plants, with fine
foliage and beautiful scarlet berries. Choice hybrids. Pkt. Ioc. Spergula Pilifera Aurea.-Golden foliage ; very dwarf; popular for edging and carpet beds. Pkt. $25 \mathrm{C}$.

Stellaria Graminea Aurea.-Golden foliage ; far richer than the Golden Feather;" splendid for edgings, etc. 1/ ft. Pkt. Isc. Statice (Sea Lavender). Excellent for winter bouquets. Hardy annual. $11 / 2 \mathrm{ft}$. Mixed. Pkt. $5 \mathrm{C}$

Tacsonia Ignea.- Magnificent climber for green-house or conservatory: fiery red; large and beautiful. Pkt. $20 c$.

ervatory; fiery red; large and beautirul. Pkt. 20c. Trifolium (Sweet Clover).- Highly valued for its fragrance; Trifolium (Sweet Clover).-Highly ralued

Viola Odorato (Sweet Violet). - A well-known, fragrant, dwarf perennial. Blue. Pkt. Ioc. White. Pkt. Ioc. Darkblue. Pkt. Ioc. Viola Odorato (The Czar).-Large and fragrant; blue. Pkt. Ioc. White. Pkt. IOC.

Viola Cornuta,-Blue. Pkt. r5c. White. Pkt. I5c.

Viola Lutea Grandiflora.-Yellow; a fine old species. Pkt. 5c. Viscaria.-Bright, handsome annual; very free flowering. I Ar. Mixed. Plat $5 \mathrm{C}$

Wahlenbergia (Bell Flower).-Hardy, herbaceous plant. with blue and white bell-shaped flowers; mixed colors. Plt. $5 \mathrm{C}$

Waitzia (Everlasting).-Yellow; charming. Hardy annual I ft. Pkt. Ioc.

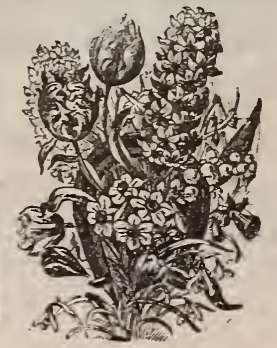

\section{SPRING FLOWERS.}

Hyacinths, Tulips, Narcissus, Lilies, Crocus, Snowdrops, Ranunculus, Anemones, Iris, Lily of the Valley Crown Imperials, Freezias, Os alis. Spiræas, Scillas and other winter and spring and other winter and s p ring blooming bulbous plants are kep in stock from September to Decem ber. We publish a special cata-
logue of these September I. Send us a postal now ; it will be mailed proper time. Customers will receive it without writing. 


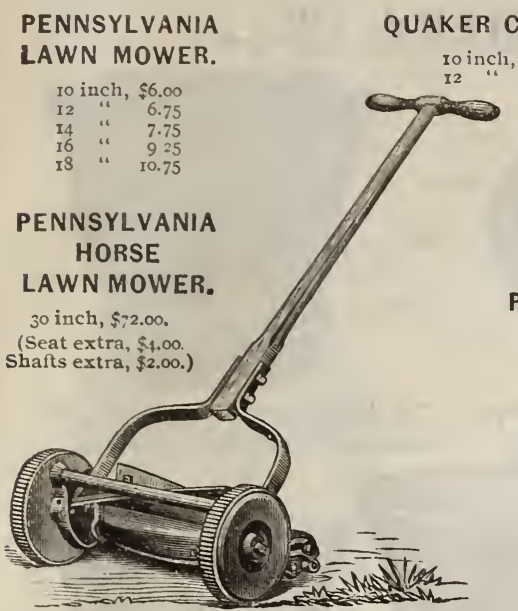

\section{PHILADELPHIA LAWN MOWER. \\ 12 inch, $\$ 7.50$ $\begin{array}{ll}14 & \text { " } \\ 16 & 9.50\end{array}$}

PHILADELPHIA HORSE LAWN MOWER.

30 inch, $\$ 67.50$.

(Shafts and Seat extra, $\$ 12.50$.

\section{PHILADELPHIA LAWN SWEEPER}

24 inch (for hand), $\$ 16.50$

40 " (for horse), 60.00
"FIRE-FLY" HAND TOOLS.

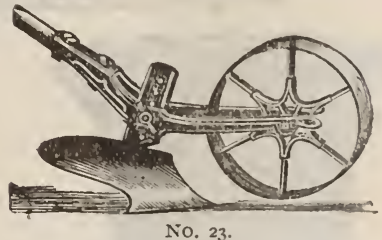

FIRE-FIYY WHEEL GARDEN PLOW. FIRE-FLY WHEEL GARDEN PLOW.-Mranufacturers' price, $\$ 2.50$; our price, $\$ 2.00$.

PLOW, WHEEL HOE AND CULTIVATÓR.-NIaHufacturers' price, $\$ 5.00$; cur price, $\$ 4.00$.

"PLANET JR." IMPLEMENTS. GARDEN SEED DRILL.-Man1facturers' price, $\$ 900$ : our price. $\$ 7.00$ No-Illustrated Catalogue of "Planet Jr." Farm and Garden Implements mailed free.

\section{ORNAMENTAL RUSTIC WORK.}

Nothing adds to the artistic finish of a lawn and grounds so much as a few well-filled rustir vases and baskets. Our stands, vases and baskets are made after the most approved patterns, and are celebrated for their elegance of outline and finish, while they are also most substantially made and will last for years. Some idea of the appearance of these vases etc.. may be obtained from the annexed engravings, each pattern being manutactured in sevei al different sizes.

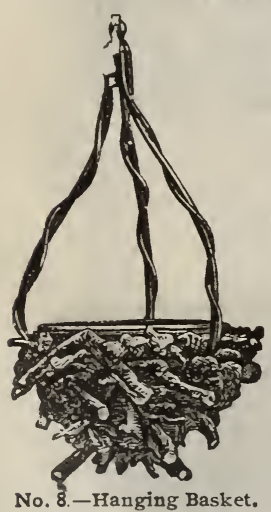

8 inches, $\$ 0.50$

$\begin{array}{rcr}8 \text { inches, } & \$ 0.50 \\ 9 & \ldots & .60 \\ 10 & \ldots & .75 \\ 11 & \ldots & .90 \\ 12 & \ldots & 1.00 \\ 13 & 1 . & 1.25 \\ 14 & . & 1.50 \\ 15 & \text {. } & 1.70\end{array}$

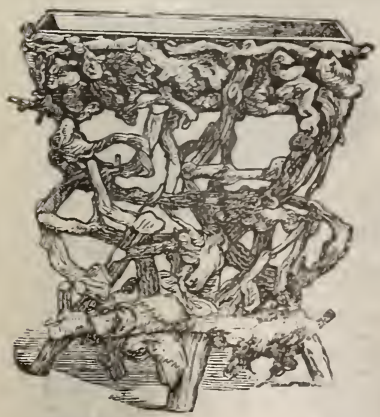

No. Io.-Oblong Vase; 18 inches, $\$ 2.25$

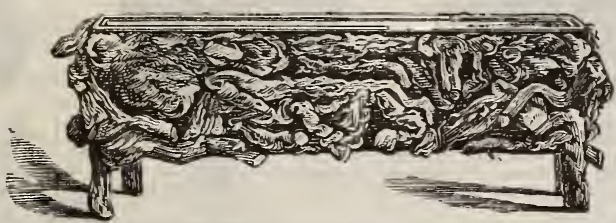

No. 13.-Window Box, 18 inches, $\$ 1.00$

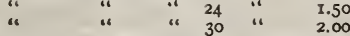

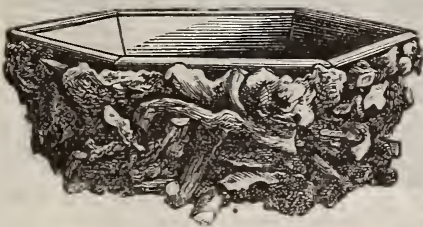

No. 11.-Stump Box, 16 inches, $\$ 1.00$

$$
\begin{array}{lllllll} 
& 11 & \text { " } & \text { " } & 20 & \text { " } & 1.50 \\
& & & 24 & & 2.00
\end{array}
$$

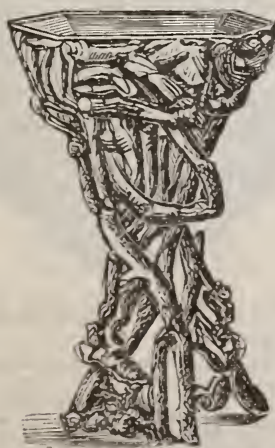

No 5.-Hexagon Vase, 16 inches, $\$ 2.00$

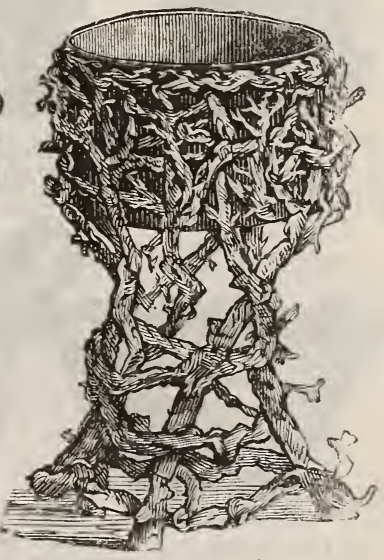

No. 19. - Round Vase, 15 inches, $\$ 4.00$

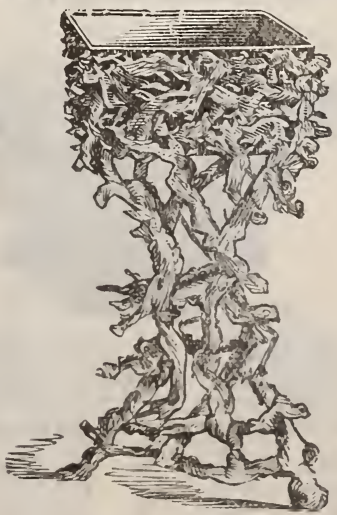

No. 18.-.Square Vase. 13 inches. $\$ 2.00$ 


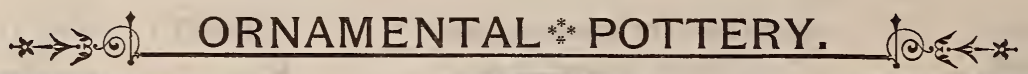
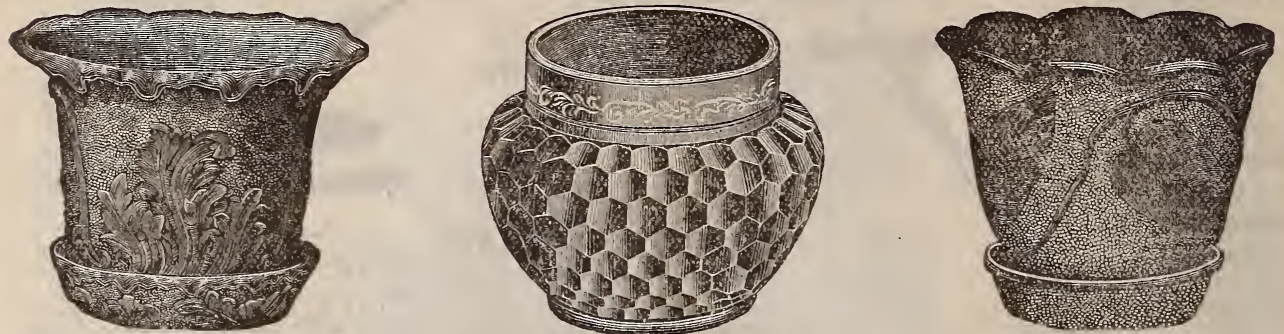

No. 220.-Flower Pot. Dark lavender, | No. 222.-Flower Por. Old gold repousse. No. 101.-Flower Pot. Old gold and ornamented with silver-grey and black. $7 \frac{1}{2} \mid 6$ inches, 50 cents each, $\$ 5.00$ per dozen. 8 in- $\mid$ bronze. 5 inches, 30 cents each, $\$ 3.001 \mathrm{er}$ doz. inches. 50 cents each, $\$ 5.00$ per dozen.
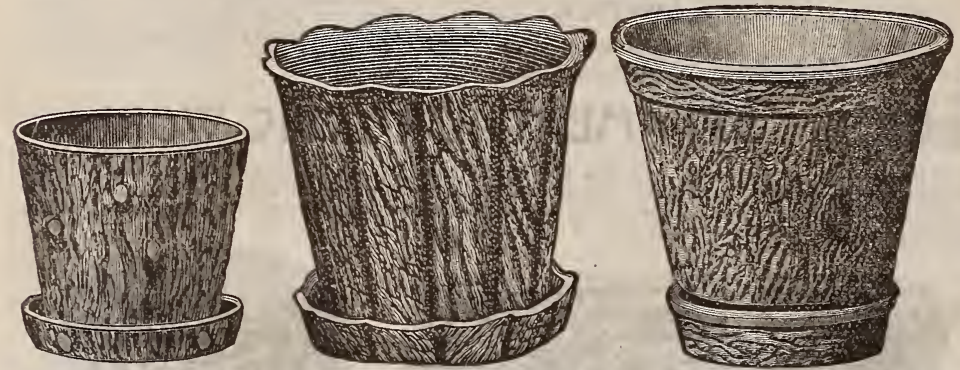

No. 3. -Flower Pot. Imitation No. 96.-Flower Pot. Rustic; No. 219.-Flower Pot. Rustic; oak. 4 inches, 17 cents each, 81.75 silver-grev. 5 inches, 20 cents each, dark brown. $41 / 2$ inches, 15 cents \begin{tabular}{l|l|l|l|} 
per dozen. $51 / 2$ inches, 27 cents & $\$ 2.00$ per dozen. 6 inches, 30 cents & each, $\$ 1.50$ per dozen. $51 / \frac{1}{\text { inches, }}$, \\
each, $\$ 2.75$ per dozen. 7 inches, & each, $\$ 3.00$ per dozen. $71 / 2$ inches, & 20 cents each, $\$ 2.00$ per dozen. 7
\end{tabular}

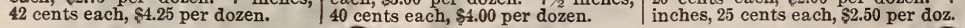

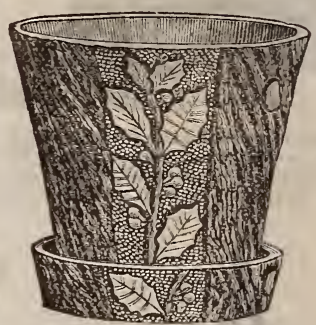

No. 75.-Flower Pot. Rustic, with holly spray (scarlet and green). $41 \frac{1}{2}$ in., 20c. each, $\$ 2$ per doz. $51 / 2$ in., 30 cents each, $\$ 3.00$ per doz.

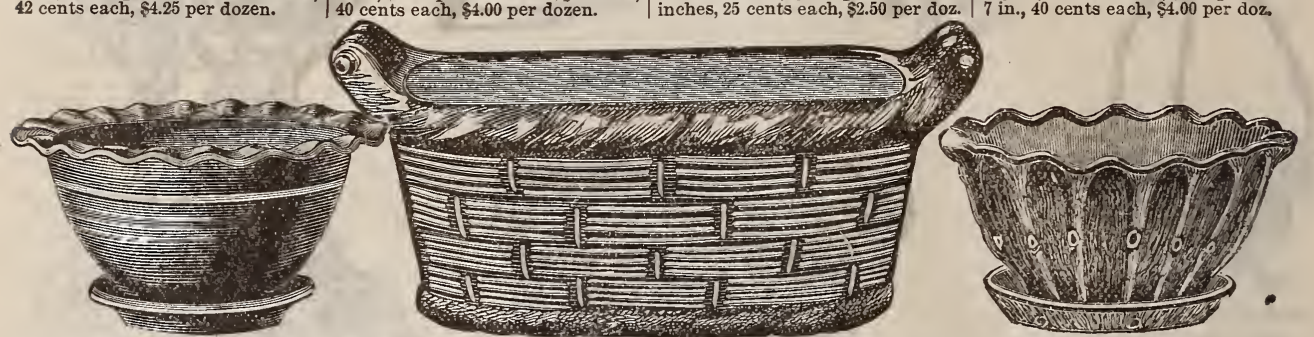

No. 16. - Hanging Pot. Carmine, with gold $\mid$ No. 52.-Hanging Bąsket. Finished in No. 19.-Hanging Pot. Rustic; deep brown,

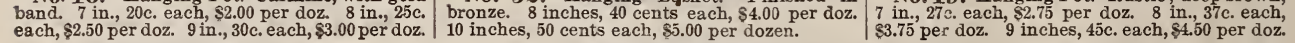
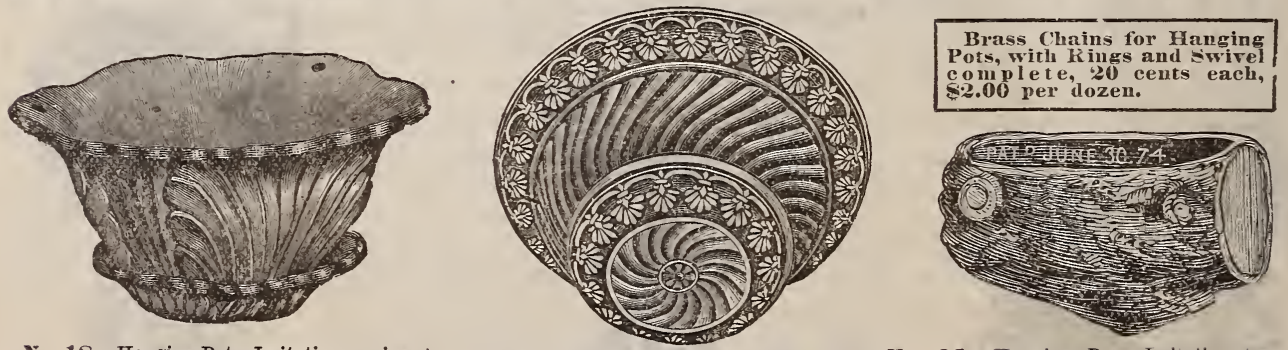

No. 18. - Hanging Pot. Imitation marine; black, blue, and gold. 7 inches, 30 cents each. $\$ 3.00$ per dozen. 8 inches, 40 cents each, $\$ 4.00$ dered with black and gold. 8 inches, 35 cents per doz. 9 inches, 50 cents each, $\$ 5.00$ per doz. STANDARD FLOWER POTS.-The style and sizes are those adopted by the Society of American Florists, 1888. Inside measurement.

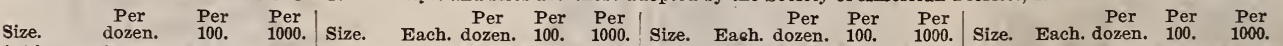

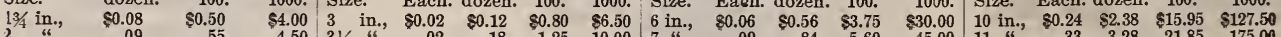

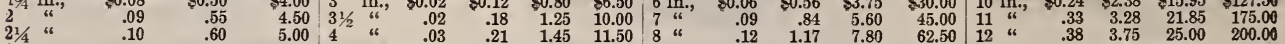

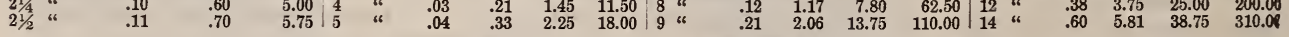

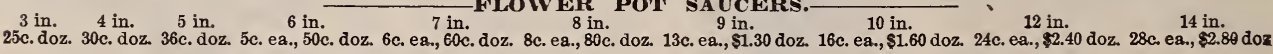
SQUARE SEED PANS.

6 in., 20c. each. 8 in., 28c. each. 10 in., 34 c. each. 12 in., 40c. each. 8 in., 18 cents each.

ROUND SEED PANS.

10 in., 21 cents each. 12 in., 24 cents each. 


\section{WIRE FLOWER STANDS!}

\section{Great Reduction in Prices!}
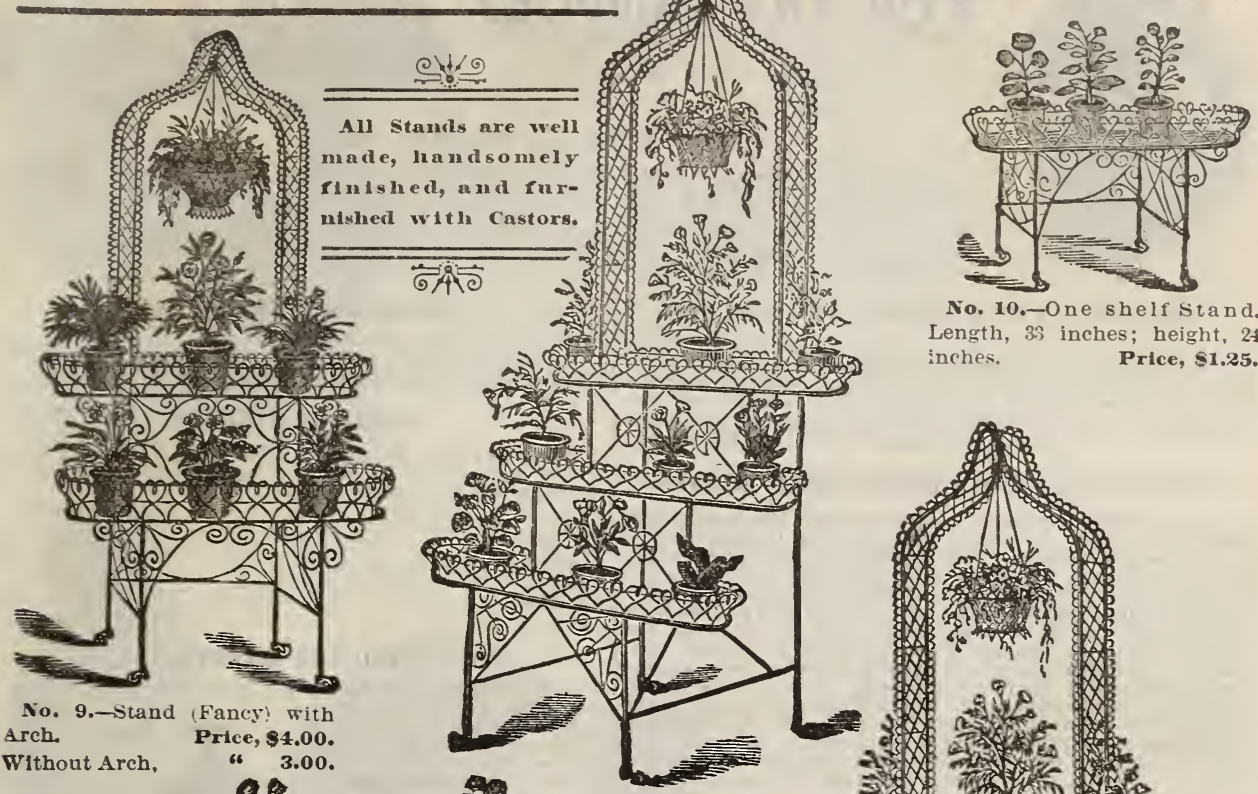

No. 10. - One shelf stand. Length, 33 inches; height, 24 inches.

Price, \$1.25.

No. 9.-Stand (Fancy) with Arch. Price, \$4.00.

Without Arch,

3.00 .

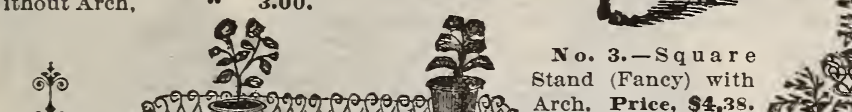

0.

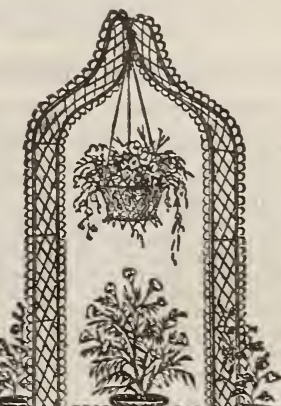

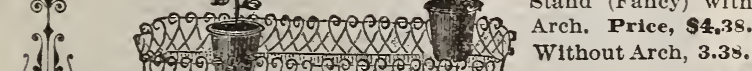

\section{edecte}

Galvanized Stands. - We can also supply nearly all these stands galvanized at a slight advance in pricn.

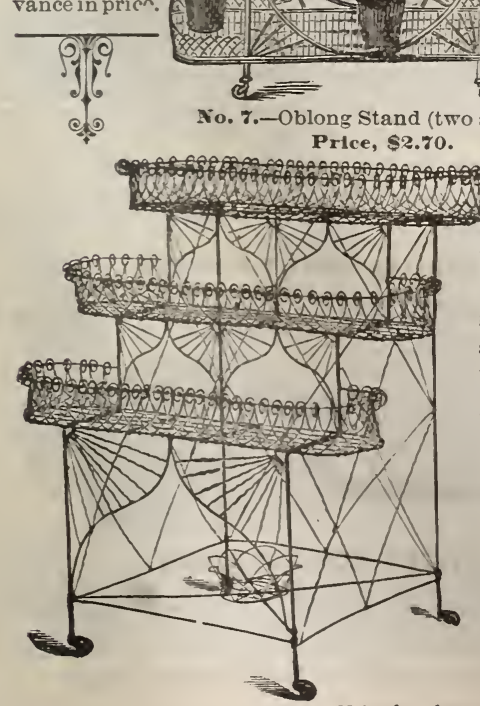

No. 5. - Square Stand (Fancy), 33 Inches long. Priee, \$3.55.

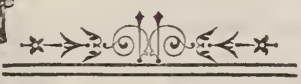
NOTICE.-Stands are generally shipped by freight, and two or three may often be shipped as cheap as one.

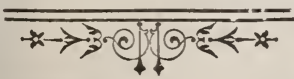

Add $25 \mathrm{C}$. for crating to abore prices for Nos, 7 and ro, and $50 \mathrm{c}$. for Nos. 2, 3, 4, 5 and 9, when the The freight companies insist on crating. 'The express companies take them either with without crates.

No. 4.-Semi-circle Stand. 42 in wide, 21 in. 36 in. long. Price, \$3.55. 

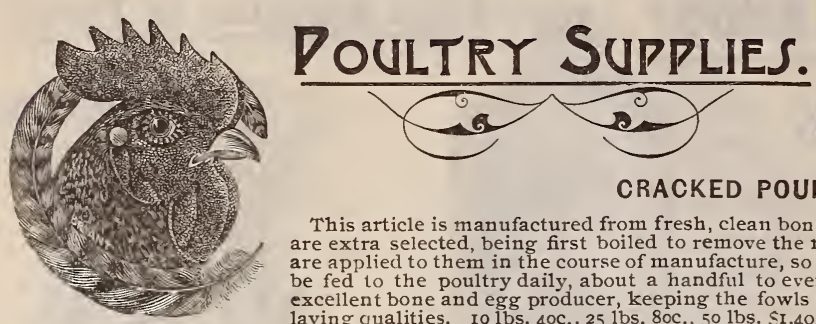

\section{CRACKED POULTRY BONE.}

This article is manufactured from fresh, clean bones, and is perfectly pure and sweet. The bones are extra selected, being first boiled to remove the meat and then ground. No chemicals whatever are applied to them in the course of manufacture, so that they are turned out green and pure. Should be fed to the poultry daily, about a handful to every five. fowls, like grain or any other feed. An laying qualities. Io 1bs. $40 \mathrm{co}, 25$ 1bs. $80 \mathrm{c}$., 50 lbs. $\$ \mathrm{I} .40$, I00 $1 \mathrm{bs}$. $\$ 2.50$.

BONE MEAL FOR POULTRY AND CATTLE.

For mixing once a day with soft feed this is unsurpassed. Laying hens and young chickens, whose digestive powers are not strong, are much benefited by this, especially during the winter months, or where closely confined in yards. This is exactly the same as the Cracked Bone described above, only it is groun much finer. Io lbs. $40 \mathrm{Oc}$., $25 \mathrm{lbs}, 80 \mathrm{c}$., $501 \mathrm{bs}$. \$1.40, 100 1bs. \$2.50.

\section{GARDINER'S CHOICE GROUND BEEF SCRAPS.}

Our ground beef scraps are in constant use by the best poultrymen in all parts of the country, who consider them invaluable for all classes of poultry. They are fresh and pure at all times, being ground from perfectly healthy meat and mixed with just the proper proportions of bone and shell-forming substances to form a complete food, which furnishes everything necessary for the successful rearing of massive, strong and healthy birds. For pouitry kept in confinement there is nothing better than this. They are both stimulating and nutritious, and splendid results can be obtained by their use, especially during cold weather. Feed three times a week at the rate of about a handful to every three birds in the morning meal of hot food. On the days when the scraps are used the amount of grain may be reduced. During warm weather the scraps need not be fed more than once a week. Per 10o 1bs. $\$ 2.50$. Sample packages : Io $1 \mathrm{bs} .40 \mathrm{c}$, $251 \mathrm{bs}$. $80 \mathrm{c}$., 50 1bs. \$1.40.

\section{BEEF CRACKLINGS.}

Fresh and sweet; in 50-1b. cakes. \$1.25.

\section{FRESH GROUND OYSTER SHELLS.}

No poultry yard should be without these during the winter months when all shell-making material is frozen over. If you want plenty of hard-shelled eggs in winter, this is the finest thing in the world for the purpose. Io lbs. $25 \mathrm{c}$, $25 \mathrm{lbs} 40 \mathrm{c}$., 50 lbs. 7cc., 100 lbs. \$I.00.

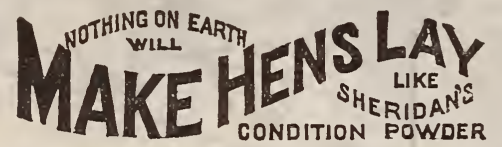

\section{SHERIDAN'S CONDITION POWDER.}

This powder is so well and favorably known that description of its merits is unnecessary. 4 oz. package, $25 \mathrm{c}$., $21 / 4 \mathrm{lb}$. can, $\$ 1.00$ Mailing, I6c. per $1 b$.

\section{Special Offer on Sheridan's Condition Powder.}

We will send post-paid by mail, as follows: A new, elegantlv illustrated copy of the "Farmer's Poultry Raising Guide," (price, 25 cents; contains a daily poultry account worth the price), and two packages of powder for foc. or one large $21 / 4.1 \mathrm{~b}$ can for $\$ 1.20$ (regular price, $\$ 1.40$ ) and Guide free. In quantity, costs less than one-teuth of a cent a day per hen

\section{IMPERIAL EGG FOOD.}

A wel1-known egg food preferred by some raisers before all other brands. 1 b. $40 \mathrm{c}$., $21 / 2$ lbs. $80 \mathrm{c}$., 6 lbs. $\$ 1.60$, Io lbs. $\$ 2.40,25$ 1bs. $\$ 6.00$. Mailing, $16 \mathrm{c}$. per $1 \mathrm{~b}$. (Only the first two sizes are mailable).

\section{JOHNSTON'S CONDITION POWDER.}

This is a very fine tonic for improving the appetite and keep ing the digestive organs perfectly vigorous and healthy. It increases the size, number and quality of the eggs, gives a delicate reduess to the comb and a glossy appearance to the plumage, a sure sign of good health, without which no bird can win
in the prize pen. $1 \mathrm{lb} .15 \mathrm{c}, 2 \mathrm{lbs}, 25 \mathrm{c}$. Mailing, 16c. 1b.

\section{HAMBURG MOSS LITTER.}

Crude. $\$ 3.00$ per bale of $3201 \mathrm{bs}$.

Prepared. Soft and friable. $\$ 1.00$ per bag.

Prepared and Medicated. Vermin-proof. \$1.25 per bag.

\section{POULTRY FOUNTS.}

Improved Patent Stoneware. This fount is acknowledged to be the best now on the market. Keeps the water cool and clean and will not upset.

Pints,

EACH. PER DOZ.

Quarts,

$1 / 2$ gallon,

1 gallon,

2 gallons,

$\begin{array}{rr}\$ 0 & \$ 25 \\ 75 & 750\end{array}$

400

10 o0

I5 00

\section{POULTRY MARKER.}

This article is a great help to the poultry keeper. It will puncting ments of the foot without pain to the fowl, thus breeds to be readily distinguished. The engraving explains the whe engraving explains the working of this invention, which
is one of the most valuable things, and offered at so low a price that it ought to be in the hands of all poultry keepers. Easily carried in the vest pocket. Made in two sizes for small and large chicks. Price, 25 c. free by mail.

\section{FRENCH POULTRY KILLING KNIFE.}

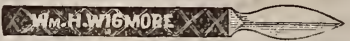

The most expeditious and humane way of killing and dressing poultry is by the French method. These knives are made of the finest steel. Price, with instructions, 50c. each.

\section{BASKETE.}

These are light, yet strongly made, and are furnished with card-boara divisions for the eggs. Each division is large enough lo allow convenient packing with "Excelsior," or other material thus making the eggs absolutely secure when shipped by express. One setting, complete. $\$ 1.50$ per doz., two settings, complete, $\$ 2.00$ per doz., three settings, complete, $\$ 2.50$ per doz. Sample basket, complete, mailed on receipt of $25 \mathrm{c}$.

\section{SOFT EXCELSIOR FOR PACKING.}

This is a most useful article and is largely used for packing eggs, etc., for shipment. Per $1 \mathrm{~b} .2 \frac{1}{2} \mathrm{c}$., in bales of 250 to $300 \mathrm{lbs}$. $\$ 1.50$ per hundred.

PERSIAN INSECT POWDER. This article is unsurpassed for use in the poultry yard. We
offer only the best quality, freshly manufactured and guaran teed absolutely pure. $1 / 2$ lb. 35 c., I 1b. 65 c. Mailing, I6c. per $1 b$.

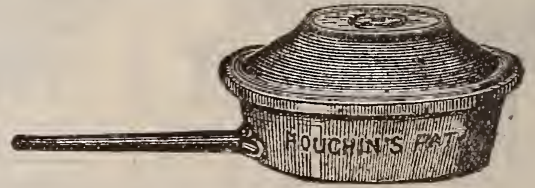

INSECT POWDER BLOWER.

The handiest and cheapest little powder gun made. At the low price at which we offer this, no one should be without it. Free by niail for $I_{5} \mathrm{C}, 2$ for $25 \mathrm{c}$. 


\title{
POULTRY $\triangle$ DEPARTMENT.
}

Our birds are bred from the purest stock, and we take the utmost pride in keepinr them up to the highest standard. For this purpose we are constantly purchasing the very finest prize takers and adding them to our own in order to always insure fresh blood. This, combined with our care in mating and breeding, makes our pnultry yards the custodian of, we believe, as fine a collection of birds as any in the vnited States. From the great number of each class bred by us we can al ways supply second shipments from a different yard, thus insuring fresh blood every time. The prices quoted in this connection are for first-class breeding fowls mated, not akin and guaranteed fault-free according to the rules of the A. P. A.

EGGS FOR HATCHING.-We warrant our egos to be true to name and fresh, but we cannot warrant any specified number to hatch, as this depends to a great extent on circumstances over which we have no control. Chicks from black breeds will occasionally show white feathers, but this does not denote impurity, as the plumage becomes solid black after moulting. Our packing is very carefully done. So that the eggs carry
safely any distance, and excellent hatches are the rule. Eggs should be allowed to safely any distance, and excer receipt before setting, as the journey generally shakes settle for a day or two

SH!PPING. - We cannot send eggs or birds C. O. D. Express companies feed and water the birds in transit and collect express charges on delivery. We notify customer by mail or telegraph as soon as the birds are dispatched.

\section{$\triangle$ INDIAN $\triangle$ GAMES A}

INDIAN GAMES.

\author{
THE FUTURE GENERAL-PURPOSE FOWL.
}

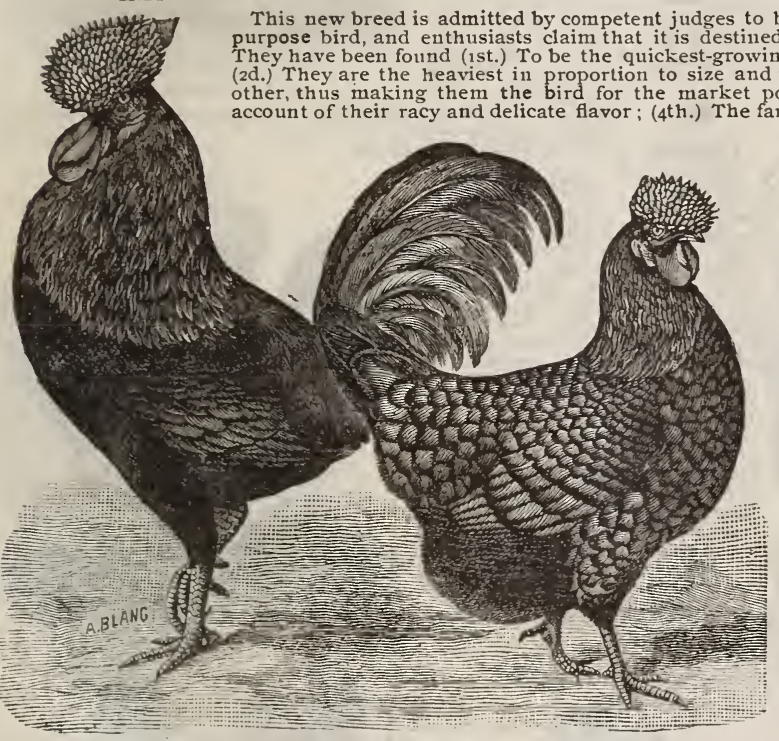

a strong rival to the Plymouth Rock as an allto take first place as soon as generally known. their an are therefore the best for broilers: their meat is more delicious in havor than any the epicure on ualities; and (5th.) The fancier delights in them on account of their handsome and dignified appearance. Birds are as yet relatively scarce here as well as in England. We can supply eggs from imported birds at $\$ 3.00$ per setting of $13 ;$ and also from birds one year from imported stock, which are nearly if not quite as good as the im

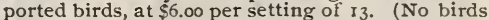
for sale this season)

- DERBYSHIRE A RED A CAPS A

These are becoming exceedingly popular in America on account of their splendid laying qualities, in which they are superior even to the Leghorn and Minorca. They are non-sitters and are greatly surpassed by some other breeds as

DERBYSHIRE RED CAPS.

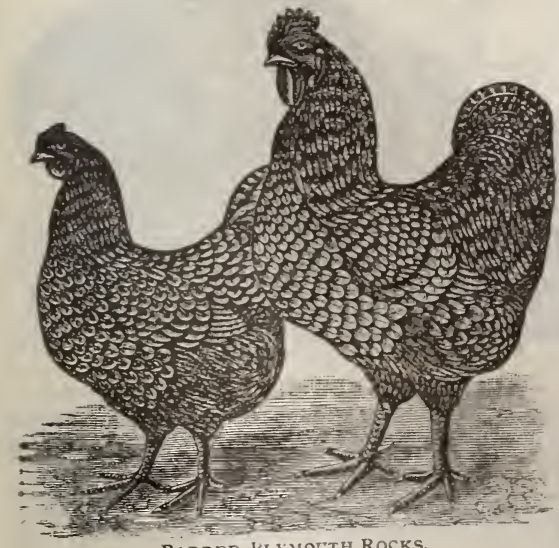

BARRED PIYYNCTH ROCKS. table fowls: but they certainly st and preeminent as egg-producers. Although not parers. Although not par-
ticularly handsom e fowls they are shapely and they will stand all $\mathrm{kind} s$ of wind and weather and still look well. Eggs, $\$ 3$ oo per I3, $\$ 5.00$ per 26 . Birds, 13, $\$ 5.00$ per.

\section{BLACK AND WHITE}

MINORCAS.

Splendid breed of BLACK MINORCA. fowls; grand style : great layers; good either for

Barred and White 13 . Fowls, $\$ 7.00$ pair, $\$ 10.00$ trio

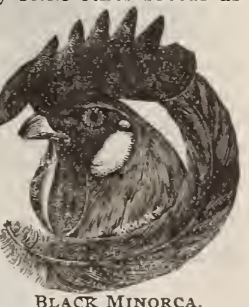
PLYMOUTH ROCKS.

As a "farmers' fowl" the Plymouth Rocks are held in the very highest estimation. Being of large size, good layers and breeders, with flesh of excelient quality and perfectly hazdy, they make a splendid all-round fowl for the farmer, both for home use and for market. They grow very fast, the cock grow very fring nine to eleren pounds, the nine to eleven pounds, the pounds. They make firstrate mothers, yet are not prove to sit too persistently, and are easily kept within bounds. In appearance they are trim and neat, as show in our engraving, with elegant plumage, clean yellow legs and good carriage thus recom me nd ing the $m$ mell as to the farmer. Eggs, \$2.50 per setting

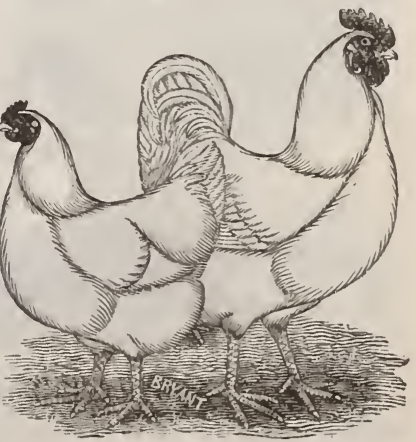

White PLyMOUTH ROCKS. of 13 . Fowls, 57.00 per pair; per trio (one cock and iwo heis), \$10.00. 


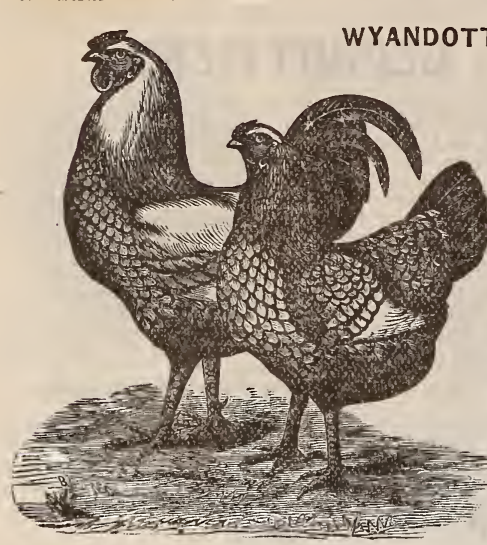

WYANDOTTES.
Distinctiy an A m e r i c a $n$ known as Sebrights, but so great 1 y i m proved of late years that they are now classed by themselves. They are large b irds, a p proaching the size, very trim and neat looking, with elegantly variegated plumage and stylish carriage. They are goodlayers and excellent table birds, perfectly hardy, b e a r well and are good mothers, although not persistent sitters. This breed is already so highly appreciated that it is unnecessary for us to praise them much; they are very popular and richly deserve to be. Eggs for hatching, \$2.50 per setting of thirteen. per pair, per trio (one cock and two hens), $\$ 10.00$.

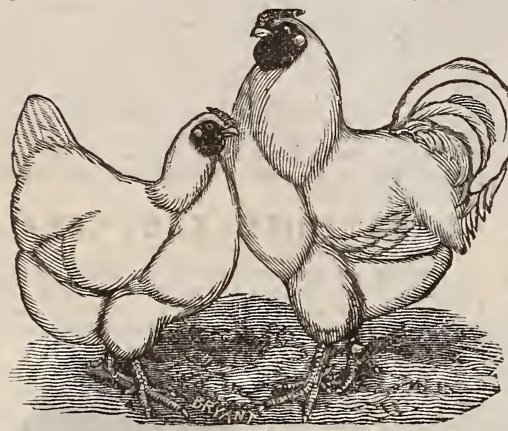

WHITE WYANDOTTES.

White Wyandottes, These beautiful birds, snowy plum trast to the barred $\mathrm{Wy}$ andottes and also possess all the other good qualities which that breed famous. For style and appearance pearance age, are splendidconthey have They commence to lay early and continue through the season and they are magnificent as a market or table fowl. They are hardy and bear confinement well and are, in short, one of the very best bieeds for home use, market or exhibition. We advise those who were disappointed last season on account of the scarcity of the eggs to let us have their orders in advance, as all orders will be filled strictly in rotation. Eggs, \$2.50 per 13 . Fowls, $\$ 7.00$ pair, \$10.00 trio.

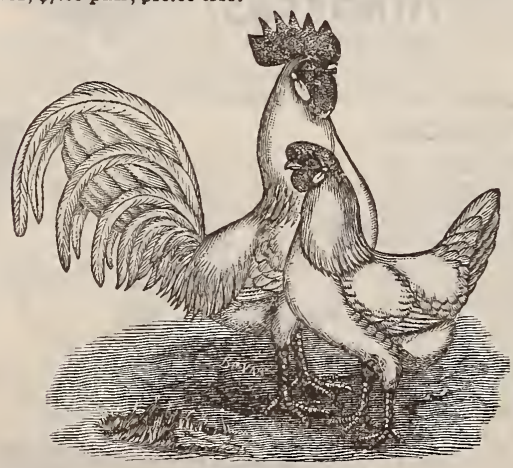

WHITE LEGHORNS.

WHITE LEGHORNS.

These do not differ from the Brown Leghorns except in their white plumage. They have the same symmetry of form, fine style and carriage, and equally astonishing laying powers; as fancy birds, they are preferred by many to the Brown, and they certainly breed truer to feather. Eggs, $\$ 2.50$ per setting of I3
Fowls, per pair, $\$ 7.00$, per trio (one cock and two hens), \$10.00.

\section{BROWN LEGHORNS.}

The Leghorns are most remarkable layers, often averaging over 200 eggs per annum. Their eggs are of the largest size, much larger than those of the Hamburgs, and produced with such long-continued regularity as to earn them the title of "laying machines." They grow very fast and commence to lay when four or five months old. Eggs, $\$ 2.50$ per setting of I3. Fowls, $\$ 7.00$ per pair, $\$ 10.00$ per trio (one cock and two hens).

\section{Black}

Hamburgs.

The Hamburgs area favorite breed of fowls, their great merit being their excellent laying qualities. They will average about per annum. The Blacks are the most popular on account of their greater hardiness and larger eggs. They are handof good form and graceful carriage. They are hardy and excellent foragers, and, given freedom, will feed
BLACK HAMBURGS.

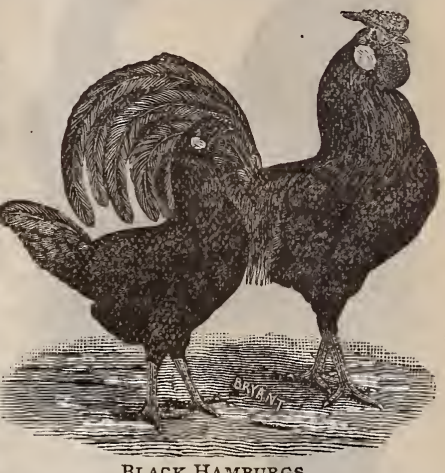

themselves, a little difficulty in keeping them in confinement. Eggs, $\$ 2.50$ per setting of $I_{3}$. Fowls, $\$ 7.00$ per pair, per trio (one cock and two hens), $\$ 10.00$.

Houdans.

This breed is highly valued for its excellent laying and table qualities. They are nonsitters, very hardy and easily reared Grow fast and areremarkably vigorous and healthy. The chickens of $t h$ is breed f 1 e d g e a nd grow exceeding 1 y fast Eggs, \$2.50 per $t$ is Fow 1 s, $\$ 7.00$ per pair, $\$ 10.00$ per trio.

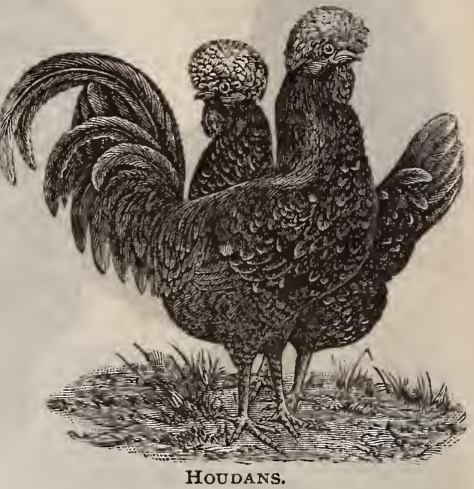
HOUDANS.

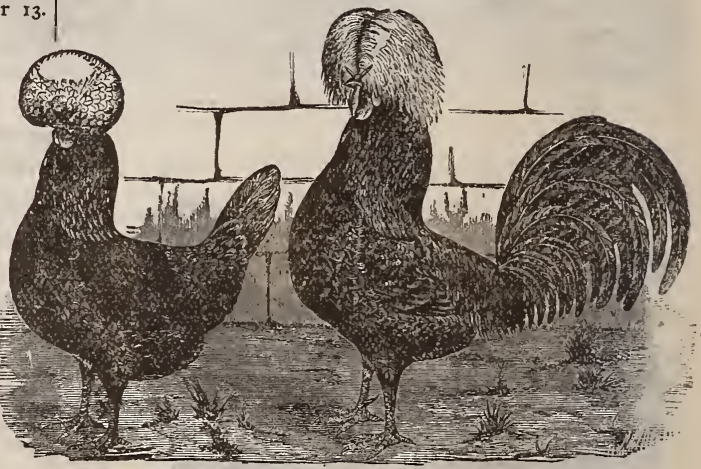

White CREsted BLACK POLISH.

\section{WHITE CRESTED BLACK POLISH.}

Handsome stylish birds with bold and graceful carriage. They are non-sitters and most prolific layers and also an excellent table fowl. They bear confinement remarkably well and suffer very little in appearance either from this or from exhibition. They what susceptible tc what susceptible to cold and roup if exposed to bad weather.
Eggs, $\$ 2.50$ per thirteen. Fowls, $\$ 7.00$ per pair, $\$ 10.00$ per trio. 


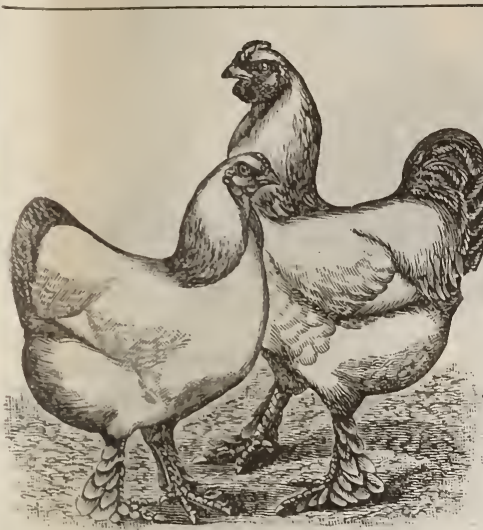

LIGHT BRAHMAS.

\section{LIGHT BRAHMAS}

The Brahmas are excellent wincom li1 ing to lay months old and producing usually about thirty eggs before com 111 e n Cing to sit, laying with out intermission all winter when other breeds are entirely stopped. In size theycer tainly sur. other breeds, and are one of the most profitable fowls both for market and home use. They seldom get out of condition from over-feeding. No poultry yard is complete without at least a few Brahmas. Our stock of Light Brahmas has been most carefully bred, and is very fine. Eggs, \$2.50 per setting of thirteen

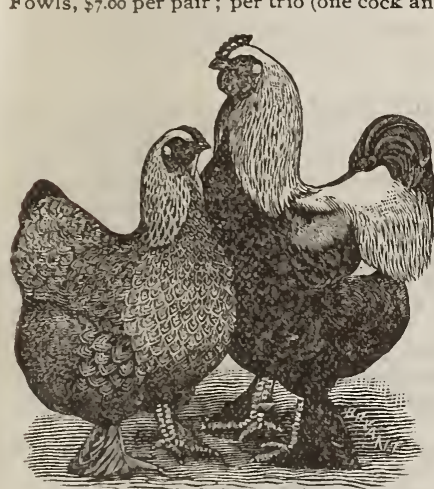

DARK BRAHMAS

\section{DARK}

BRAHMAS

In form the Dar Brahmas are u pright and sprightly with the great width and depth which characterize all Brahmas. As fancy birds there are few that can they are held in the highest admiration by a 11 poultry keepers. They are very tame and stand confinement well yet are good foragers when allowed liberty. Fggs, \$2.00 per setting of thir teen. Fowls, $\$ 7.00$ per pair; per trio hens), $\$ 10.00$

\section{BUFF COCHINS.}

Are a valuable breed, and deserve the attention of all poul. try keepers. They are very ta $111 \mathrm{e}$, e a sily domestic a te d: seldom quarrel. and will thrive in a very limited run. The young chickens are hardier than ally other breed except B rah mas, grow fast, killing when twelve weeks old. As sitters

and mothers.

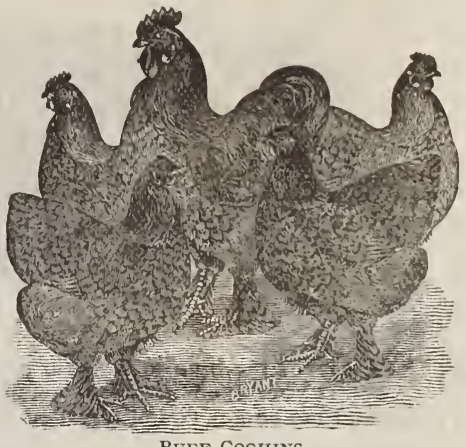

BUFF COCHINS.

the hens are unsurpassed; they are prolific layers, especially in winter, when eggs are scarce; they cannot fly, and a fence two feet high will keep them within bounds. Our stock is pire and unsurpassed. Fowls, \$7.0o per pair; per trio (one cock and two hens), \$10.00. Eiggs for hatching, \$2.50 per setting of thirteell.

A limited number of settings can be supplied from a remarkable prize pen of Buffs imported this season. Price, $\$ 4.00$ per setting. Orders filled strictly in rotation

\section{Partridge Cochins. \\ These have all the mer its of the a rever stylish hand some birds. good for fa mily use for eggs and chickens, and splendid as a $\mathrm{fancy}$ show bird. Eggs, \$2.50 per thirteen Fowls, $\$ 7.00$ per pair $\$$ Io.0otrio.}

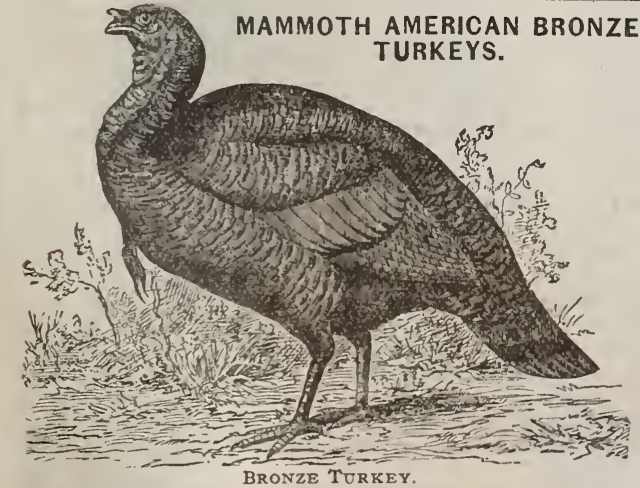

This breed is the largest, hardiest, firmest fleshed, and highest flavored of all gobblers, and will grow and fatten quicker thai any other. Eggs, $\$ 3.00$ per $6 ; \$ 5.50$ per 12 . Birds, $\$ 7.00$ each (tom or hen), \$12.00 pair (mated); \$16.00 trio (mated).

\section{WHITE HOLLAND TURKEYS.}

The White Hollands are not only beautiful in plumage, but they are also the tamest and most domestic of any. They are also of good size and profitable either for home use or market. Eggs, $\$ 2.50$ per $6, \$ 4.50$ per 12 Birds, $\$ 5.00$ (tom or hen), $\$ 10.00$ pair (mated), \$12.50 trio (mated)

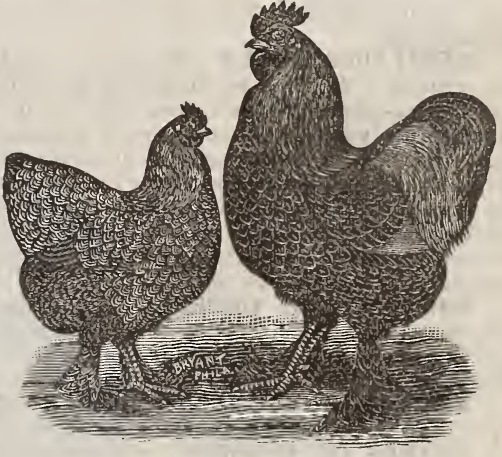

PARTRIDGE COCHINS.

\section{WHITE PEKIN BANTAMS.}

The most remarkable and singular breed of Bantams in existence. A perfect miniature oriental possessing the feathered leg, abundant fluff, and all the other characteristics in the fullest perfection. Very rare. Eggs, \$5.00

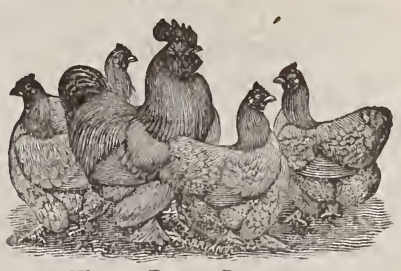

White PEKin Bantams.

\section{PEKIN DUCKS.}

We have a good strain of this popular and profitable breed of ducks. The Pekins are good layers, and are easily confined, and require only water enough for drinking purposes. They have creany-white plumage, orange legs, and yellow bills; grow large, and can be marketed you ng. Their size, weight, and other good qualities have made them popular

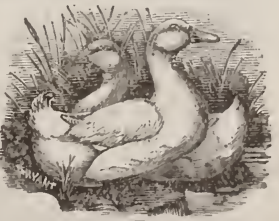

PEKIN DUCKS. all over the hatching, \$2.25 per setting.

\section{AYLESBURY DUCKS.}

White, larger than the Pekins. We offer a limited number of settings from a prize pen just imported $\$ 4.00$ per settine. 


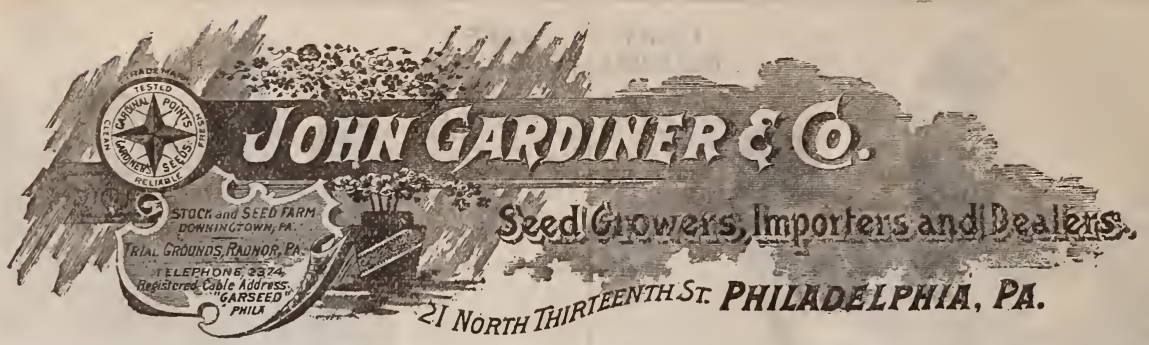

JANUARY I, 1891.

Winter.is the time to lay your plans for next season's operations on the farm and in the garden, and to select your seeds from the seedsman. Therefore, order your seeds now. Do not lay this book aside till planting time comes round. Order now, while you have plenty of time to study our list thoroughly.

\section{PLEASE READ CAREFULLY WHEN SENDING ORDERS.}

ADDRESSING.-We would earnestly request all customers when sending orders to carefully fill in their full name and address, stating also their nearest express and freight offices. There are so many forgetful people who send orders and money without their names, that we deem this caution very important, owing to the fact that the recipients naturally get blamed for not shipping the order when they are entirely innocentnot knowing where to send.

ORDER SHEET.-For writing out orders, the order sheet enclosed with Catalogue will be found more convenient than an ordinary sheet of paper, and by using the printed envelope, there is less danger of letters miscarrying.

REMITTING MONEY.-We receive postage stamps the same as cash, and postal notes are generally very convenient, but, when sending money, we recommend for safety, where possible, to remit either by registered letter, post-office order, express order, or by draft on New York. Remittances sent in any of these four ways are absolutely safe, and we not only guarantee their safe arrival, but we will also bear the expense of so sending. The cost of remitting the money may be deducted from the amount sent. In making remittances be careful to send sufficient to cover the amount of goods ordered. In cases of short remittances, we will limit the shipment to the amount of money received. We are compelled to adopt this rule on account of the inconvenience and expense of collecting small balances. We never send goods C. O. D., unless one-fourth of the amount is sent as a guarantee of good faith. Goods cannot be sent C. O. D. by freight, neither can we send perishable goods or live stock C. O. D.

SHIPMENTS OF ORDERS.-A1l orders are booked, assorted, and filed the day they are received, and despatched the day following, or a reason given for delay, if any should happen, which seldom occurs, as our excellent facilities and large force of skilled employés enables us to forward all orders promptly, even in the height of the busy season.

ARRIVAL OF PACKAGES GUARANTEED. - We guarantee the safe arrival of packages at destination. If a package fails to reach a customer, we will send again as soon as informed of the fact.

CHANGE OF ADDRESS.- Should you make any change from your present address, we will esteem it a favor if you will notify us, so that we can forward our Catalogues with regularity.

DUPLICATE CATALOGUES.--Sometimes customers will receive our Catalogue twice by mistake, in such cases kindly hand it to some friend who would be likely to be interested.

RECOMMENDATION.- The favor of your kind recommendation of our firm to any friend in want of seeds or bulbs, is respectfully solicited.

ERRORS. - We take the utmost care in filling orders, always striving to do a little more than even-handed justice. Should an error occur, we desire to be promptly informed, and will take pleasure in making satisfactory corrections.

SATISFACTION GUARANTEED. - We realize miost fully that in the seed business-more so than in any other- "a pleased customer is the best advertisement," and our undivided attention is given to satisfying our patrons, so that they sliall remain with us permanently. From past experience we are confident of our ability to please the most fastidious, and all we ask of those who have not yet dealt with us is to send us a trial order and be convinced of the superior quality of our seeds, and our fair and square method of doing business.

QUALITY.-Our seeds are Fresh, Clean, Tested and Reliable. Our facilities for handling seeds are unsurpassed, and we take the greatest precautions to avoid error-every safeguard that human ingenuity cau devise in system and improved appliances is used, regardless of expense, to ensure correctness.

OUR PRICES. - The cheapest seeds are not always the best, but the best seeds are always the clieapest. Our seeds are as low in price as is consistent with the best quality.

FREE BY MAIL. - All vegetable ard flower seeds, in packets and ounces, are sent free by mail, wlien ordered at Catalogue prices. Pounds and quarts are figured without delivery charges, and postage must be added to cover same, if wanted by mail.

DISCOUNTS ON PACKETS.-To encourage our patrons to form clubs, we offer the following liberal premiums on ALL SEEDS IN PACKETS ordered at Catalogue prices :

On all orders for seeds in packets the purchaser may select TWENTY-FIVE CENTS' WORTH EXTRA FOR EACH ONE DOLLAR SENT US. Thus, any one sending us $\$ 1.00$, can select seeds in packets amounting to $\$ 1.25$; for $\$ 2.00$. seeds in packets to the value of $\$ 2.50$; for $\$ 3.00$, to the value of $\$ 3.75$, and so on. Please tell you friends of our liberal offer. This discount applies only to seeds in packets. 


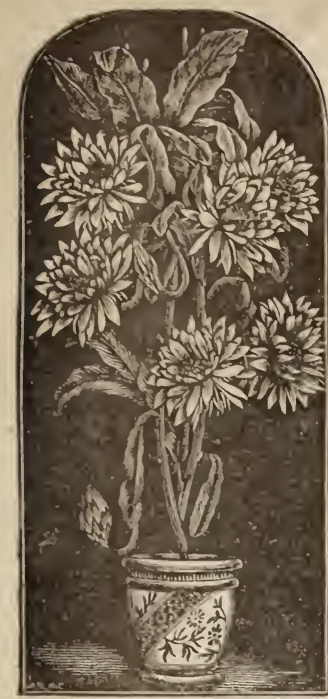

THE QUEEN CACTUS.

PHYLLOCACTUS LATIFRONS.

This is certainly the most desiro

ence. It is of rapid growth, sure to
bloom, and easy to manage, bears

fiowers often 10 inches across, de-
lightfully fragrant, and pure white

in color. Grows any where. 2.5c.,
50c. and $\$ 1.00$ each, according
to size.

GOOSEBERRY CACTUS.

ECHINOCACTUS SIMPSON1.

A remarkably free bloomer. Distinct in color, being a rich crimson. Flowers a temperature of 40 degrees. ' 20 cents.

SILVER SPINES (Opuntia Emory.) Has art. Iarge sellow fow Perfectly hardy anywhere. A very rare sort, and perhaps the finest Opuntia. 20c.

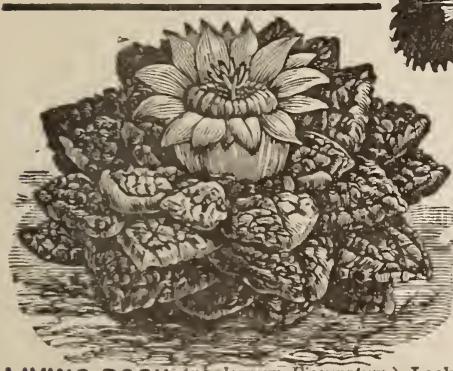

LIVING ROCK LIVING ROCK ing at this currousity, no one carvel wood it was a planto look spent. So tenacions of life is it that it need not be
watered more than once a month. When in bloom it is yet more attractive. Sold elsewhere at $\$ 2.00$ to 85.00 each. Our price is 50 cents each.

CEREUS TRIANGULARIS. Stock $\mathrm{th} \mathrm{r} e \mathrm{e}$

ers very large, white; sepals green. 20 cts.

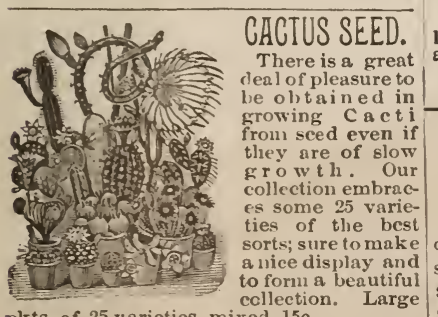

pkts. of 25 varieties, mixed, $15 \mathrm{c}$.

\section{CEREUS GRANDIFLORA}

\section{MIGIT-BLO0JING CERECS.}

Flowers enormously large, and of rarest

This is the true Queen of Night.

\section{SPECIAL OFFER.}

The 24 Rare Cacti oul this lage would cost, at lowest prices, $\$ 5.15$; but we will $\$ 4.50$ or without the Pilocereus for $\$ 3.75$.

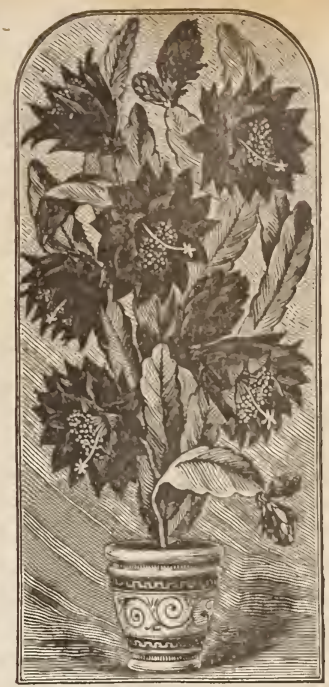

THE KING CACTUS. PHYLLOCACTUS ACKERMAKMI. A magnificent day bloomer, with
flowers 5 to 6 inches across, of the most brilliant crimson color imaginable. Blooms first year. One
of our best. 2.5c., 50c. and $\$ 1$

each, according to size.
PHYLLOCACTUS ROSEA. Flowers pink. $25 \mathrm{c}$., four dls-
tinet sorts for 75 cents. TLE FISH HOOK LIT (ECHINOCACTUS SETISPINUS.) One of the very best bloomers to be had; it
blooms from summer till late in the fall. Large flowers, yellow, with beantiful red centre.
Place in the sun while blooming. '20e. to \$1. CANDLE CACTUS (Opuntia Lurida). Is not often found in collections. Large branching plants, the spines of which glisten in the sun. Large yellow and purple
produced. 20 cents each.

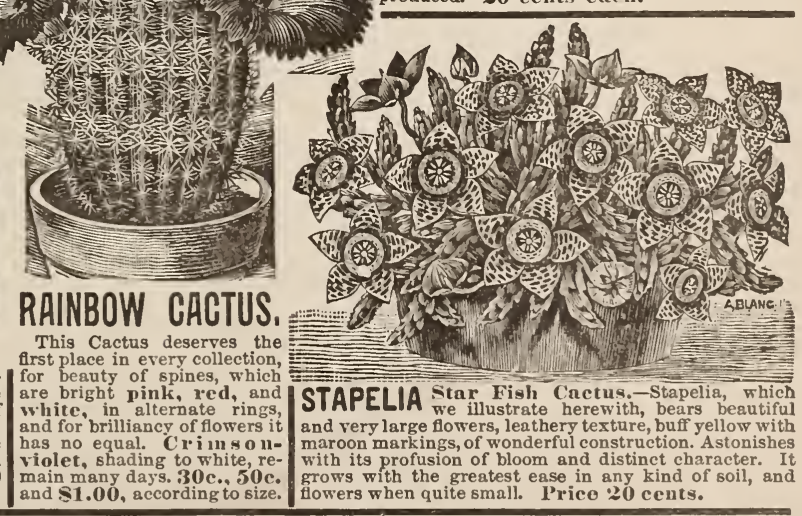

EPYPHILLIUM TRUNCATUM.

cimison-scarlet. Winter bloomer. 20c.

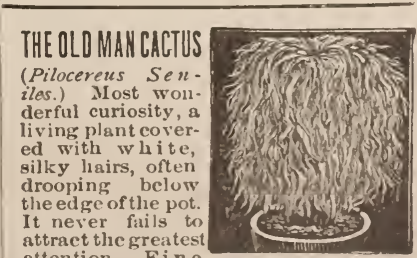

specimens at $\$ 3.00 \$ 5.00$ or $\$ 10.00$ each.

Nice young plants $\$$ r. 00 each. 


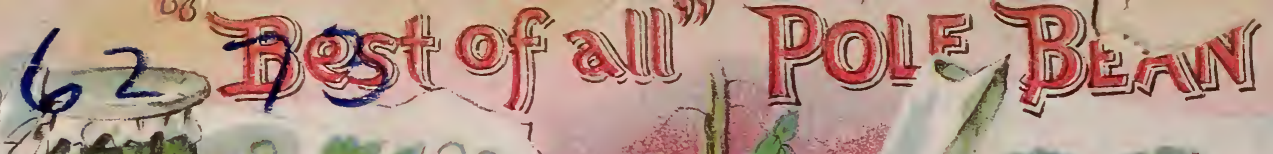

potr 29

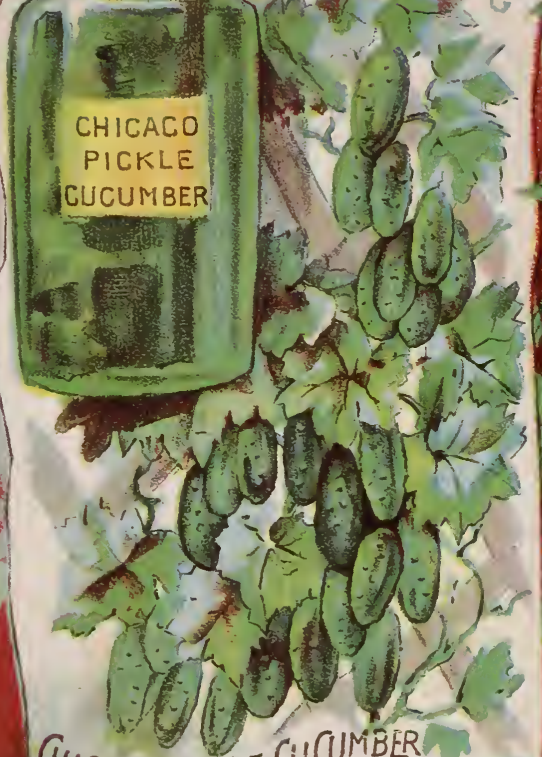

(HICAGO PICKE CUCUMBER I

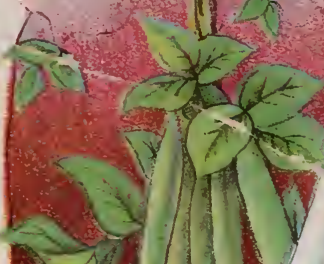

unsurpassed in quality

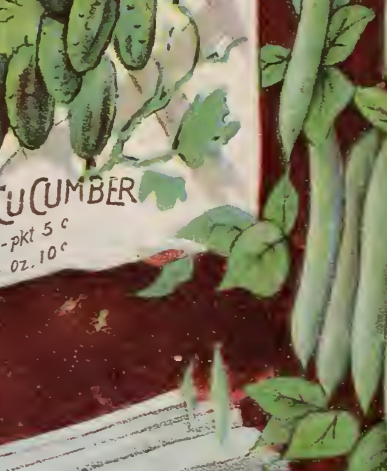

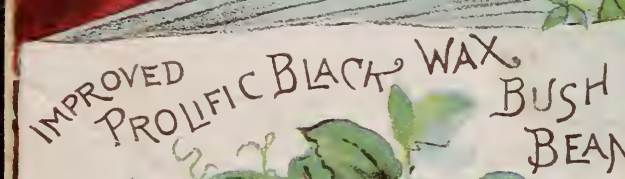
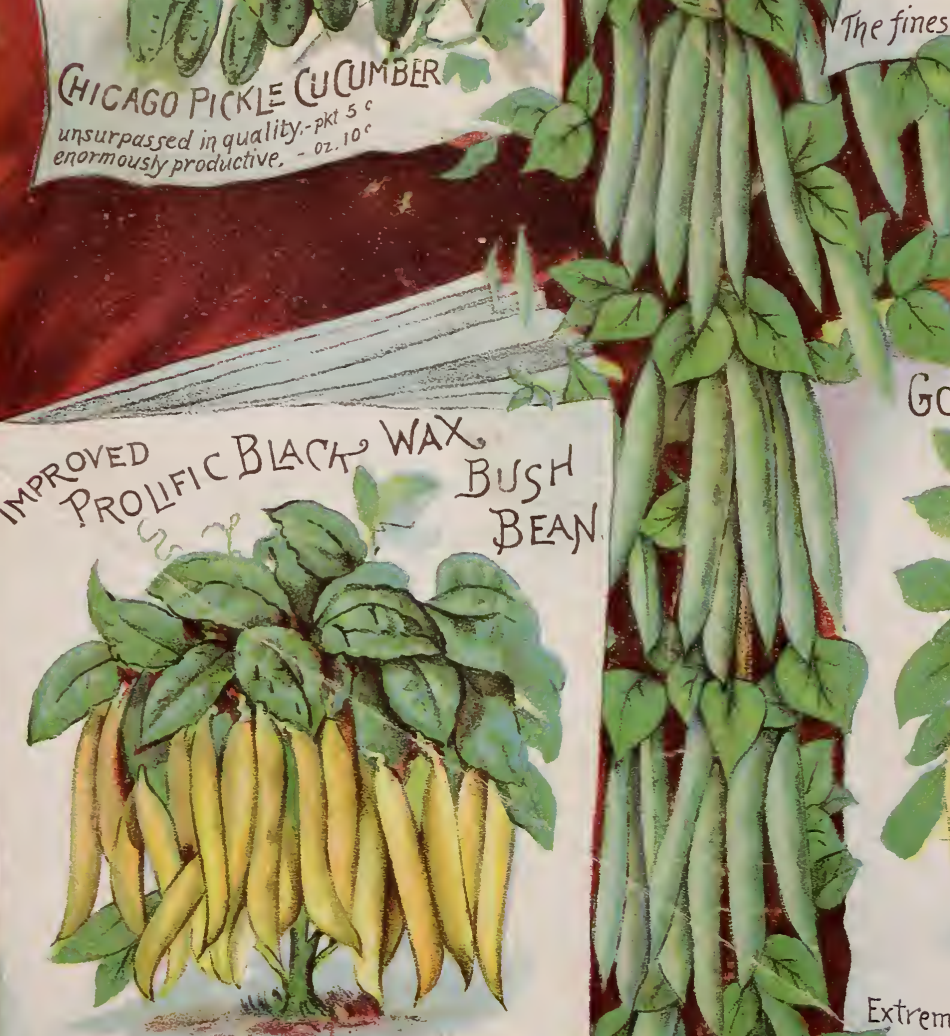

Greatly improved strain, extra early

Stringless, very heavy cropper.
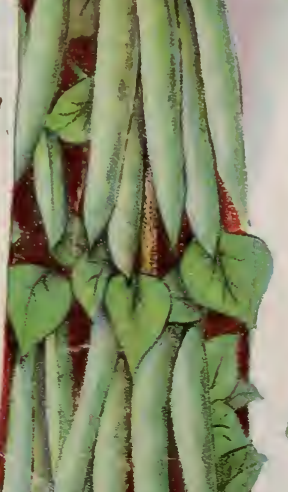

$1 / 1+2$

GOLDEN EYED BUSH PEAN

112 Extremely early, very productive and superb quality, rust proof and free from spot.

A spiendid nerr bean. pkt. $10^{\circ} 3 \mathrm{pkt} .25^{c}$ 